\title{
Bolten, Viriginia
}

\section{La voz de la mujer : periódico comunista-anárquico, 1896-1897}

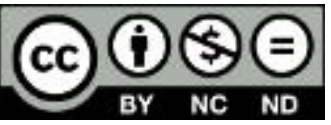

Esta obra está bajo una Licencia Creative Commons Argentina.

Atribución - No Comercial - Sin Obra Derivada 2.5

https://creativecommons.org/licenses/by-nc-nd/2.5/ar/

Documento descargado de RIDAA-UNQ Repositorio Institucional Digital de Acceso Abierto de la Universidad Nacional de Quilmes de la Universidad Nacional de Quilmes

\section{Cita recomendada:}

Bolten, V. (Dir.) (2018). La Voz de la Mujer. Periódico Comunista-Anárquico, 1896-1897. Bernal, Argentina: Universidad Nacional de Quilmes. Disponible en RIDAA-UNQ Repositorio Institucional Digital de Acceso Abierto de la Universidad Nacional de Quilmes http://ridaa.unq.edu.ar/handle/20.500.11807/2240 

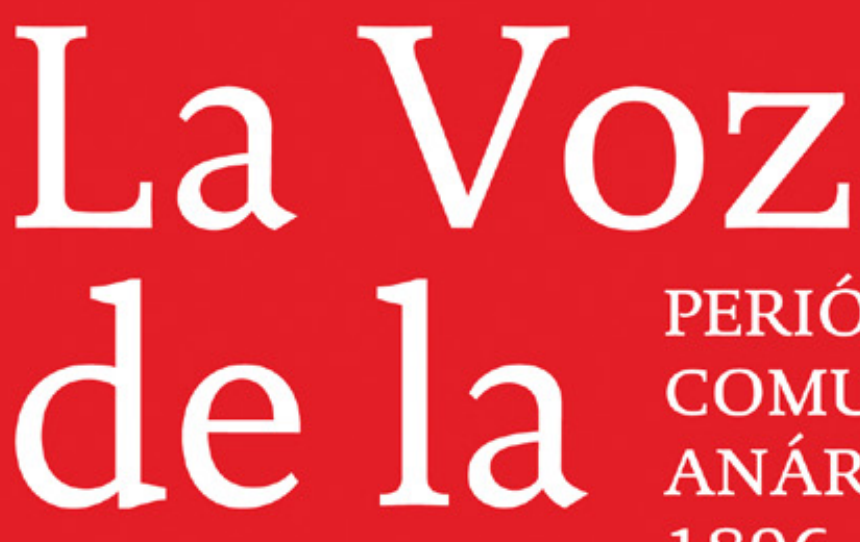

\section{PERIÓDICO COMUNISTA ANÁRQUICO} 1896-1897

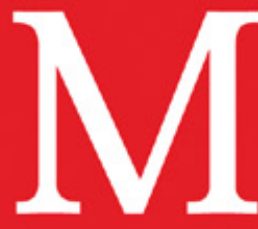

○

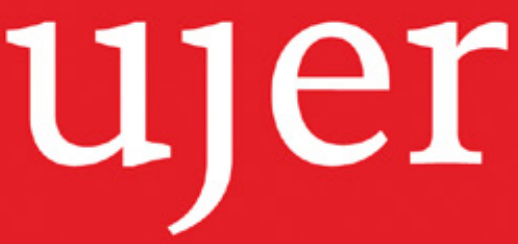

Prólogo de Dora Barrancos

Nota de María del Carmen Feijoó

Presentación de Maxine Molyneux

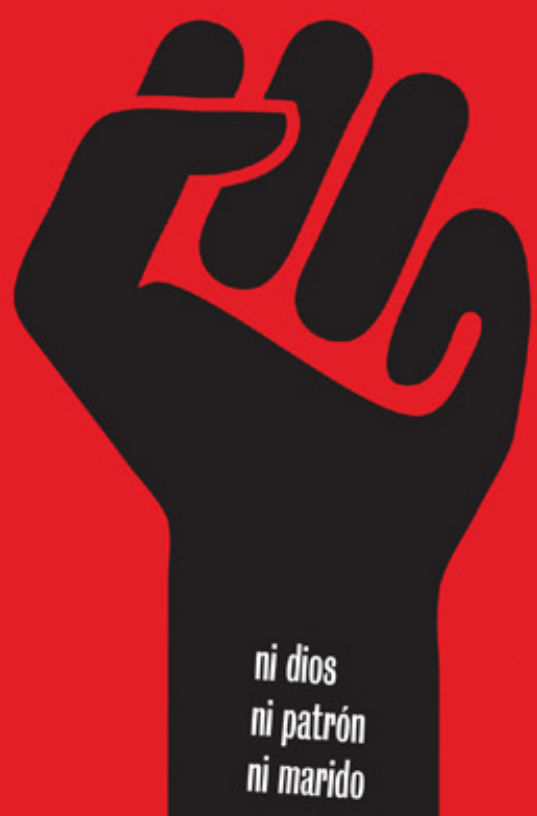


La Voz de la Mujer

Periódico Comunista-Anárquico 
UNIVERSIDAD NACIONAL DE QUILMES

Rector

Alejandro Villar

Vicerrector

Alfredo Alfonso 


\title{
La Voz de la Mujer \\ Periódico Comunista-Anárquico 1896-1897
}

\author{
Prólogo de Dora Barrancos \\ Nota de María del Carmen Feijoó \\ Presentación de Maxine Molyneux
}

Universidad

Nacional

de Quilmes

Editorial

Bernal, 2018 
La ideología argentina

Colección dirigida por Oscar Terán (1938-2008)

La voz de la mujer: periódico comunista-anárquico: 1896-1897; prefacio de María del Carmen Feijoó; Maxine Molyneux; prólogo de Dora Barrancos. - 2a ed. - Bernal: Universidad Nacional de Quilmes, 2018. 168 p.; 23 x 15 cm. - (La ideología argentina / Oscar Terán)

ISBN 978-987-558-536-2

1. Historia Argentina. 2. Feminismo. 3. Publicaciones. I. Feijoó, María del Carmen, pref. II. Molyneux, Maxine, pref. III. Barrancos, Dora, prólog. CDD 305.42

Primera edición, 1997

Segunda edición, 2018

(C) Universidad Nacional de Quilmes, 1997

Universidad Nacional de Quilmes

Roque Sáenz Peña 352

(B1876BXD) Bernal, Provincia de Buenos Aires

ISBN: 987-9173-08-2

Queda hecho el depósito que marca la Ley Nº 11.723

Impreso en Argentina 


\section{ÍNDICE}

Prólogo a la segunda edición, por Dora Barrancos .............. 9

Nota editorial, por María del Carmen Feijoó . . . . . . . . . . . . 15

Presentación. Ni Dios, ni Patrón, ni Marido. Feminismo anarquista

en la Argentina del siglo xix, por Maxine Molyneux .............

La Voz de la Mujer

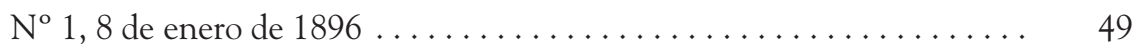

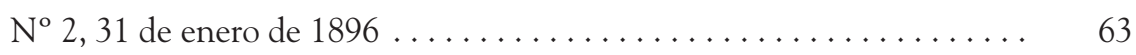

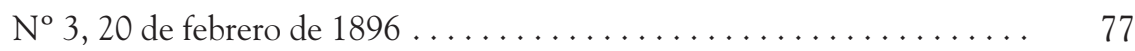

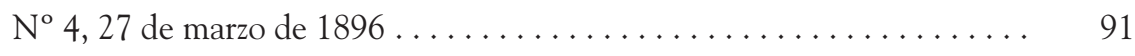

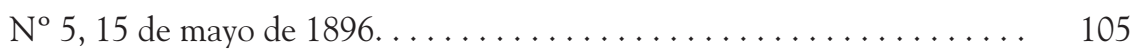

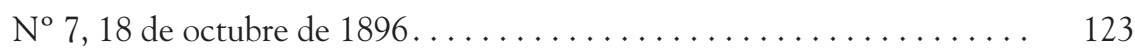

$\mathrm{N}^{\mathrm{o}} 8,14$ de noviembre de $1896 \ldots \ldots \ldots \ldots \ldots \ldots \ldots \ldots \ldots \ldots \ldots$

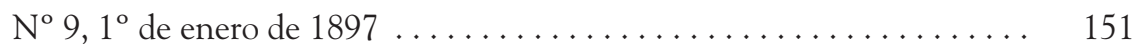





\section{PRÓLOGO A LA SEGUNDA EDICIÓN}

Debemos celebrar aquí la reedición del libro La Voz de la Mujer. Periódico comunista-anárquico por la Editorial de la Universidad Nacional de Quilmes, que en 1997 se propuso reproducir la totalidad del material localizado y legible de los nueve números de esta publicación feminista anarquista. Han pasado más de dos décadas de ese acontecimiento editorial, y no puede ser más justificada la decisión de este nuevo lanzamiento. El contexto de efervescencia feminista de los últimos años, las evidencias múltiples de la adhesión masiva a sentimientos antipatriarcales por parte de las generaciones más jóvenes -tal como se ha observado en las movilizaciones recientes a favor de la legalización del aborto en nuestro país-, la amplitud de la acogida académica de los estudios acerca de las mujeres, de las relaciones entre los géneros y la impronta de las disidencias sexo-genéricas han sido estimulantes decisivos para que vuelva a circular La Voz de la Mujer, el periódico comunista-anárquico que vio la luz entre 1896 y 1897 . No fue la primera publicación destinada a las mujeres y sostenida en buena medida por plumas femeninas en la Argentina. Es necesario evocar las primeras hojas en las que predominó la escritura de mujeres, La Argentina y La Aljaba -ambas de inicios de la década 1830-. Con relación a La Argentina ha sido reiterada la adjudicación de su dirección a un varón, Manuel Irigoyen, pero de acuerdo con el riguroso análisis que César L. Díaz le ha dedicado, ${ }^{1}$ debe admitirse que muy probablemente fueran mujeres quienes estuvieran a su cargo. En el caso de La Aljaba, siempre se ha sostenido que su editora fue Petrona Rosende de Sierra, pero lo cierto es que ambas publicaciones se destinaron al público femenino y de acuerdo con el citado análisis de Díaz, no faltaron tensiones entre estos pioneros grupos editoriales dedicados a las lectoras mujeres, más allá de la coincidente sintonía política con el gobierno de Juan Manuel de

${ }^{1}$ La Argentina: 1830-1831, estudio preliminar de César L. Díaz, La Plata, Instituto Cultural de la Provincia de Buenos Aires, Dirección Provincial de Patrimonio Cultural, Archivo Histórico “Dr. Ricardo Levene”, 2011. 
Rosas. Graciela Batticuore ha destacado que estas publicaciones, aunque proponían la ilustración de las lectoras, "abogaban por un protagonismo femenino circunscripto al ámbito de la domesticidad, la familia o la intervención social por vía indirecta (vale decir, por vía de su 'influencia' pacificadora, no de la participación activa en la vida social y política)".

Desde mediados a fines del xix hubo sin dudas una ampliación del número de mujeres que escribían y mantenían publicaciones, como ocurrió con Juana Manso -notable educadora- y su revista La Redacción. Álbum de señoritas. Periódico de literatura, modas, bellas artes y teatro, tal el título completo de aquella empresa editorial surgida en 1854 y que seguramente quiso ser la continuidad de la hoja que había publicado unos años antes en Brasil, O Journal das Senhoras. Y más cerca del fin de ese siglo se destacaron al menos dos editoras mujeres, Juana Manuela Gorriti -singular novelista e historiadora amateur-, responsable de La Alborada del Plata, y la peruana, también descollante escritora, Clorinda Matto de Turner con Búcaro Americano, que casi coincidió con la aparición de La Voz de la Mujer. Ese fin de siglo resultó muy alterado, la modernidad se impuso a zancadas, una vorágine de cambios materiales en la sociedad argentina, y si hubo transformaciones tangibles en los grandes centros urbanos, en especial Buenos Aires y Rosario, se refieren a la cambiante demografía con miles y miles de inmigrantes de ultramar que darían una nueva fisonomía social y cultural al país. Las mujeres letradas, a pesar del sometimiento formal al cónyuge traído por el flamante Código Civil -puesto en vigor en 1871-, pudieron acceder a renovadas fuentes de información. Las lecturas recorrían desde los diarios a las revistas de información general pero, sobre todo, la avidez por leer se centró -como un fomento a la imaginería transgresora- en las novelas. Ha sido muy analizado el formato del folletín que concentrará el deseo consumidor letrado entre las mujeres -debe recordarse el análisis de Beatriz Sarlo ${ }^{3}$ en nuestro medio y de Anne-Marie Thiesse ${ }^{4}$ con relación a Francia-, género que debe verse como provocador de subjetividades que hasta pueden conspirar contra la canónica moral patriarcal. Las publicaciones destinadas a las mujeres en manos de editoras de tanta respetabilidad literaria como Gorriti y Turner podían ser amenazantes para ciertos sectores sociales, aunque apenas animaran mohines de disconformidad.

${ }^{2}$ Batticuore, Graciela, Lectoras del siglo xIx. Imaginarios y prácticas en la Argentina, Buenos Aires, Ampersand, 2017, p. 48.

${ }^{3}$ Sarlo, Beatriz, El imperio de los sentimientos, Buenos Aires, Catálogos, 1985.

${ }^{4}$ Thiesse, Anne-Marie, Le Roman du Quotidien, lecteurs et lectures populaires à la Belle Epoque, París, Seuil, 2000. 
Si por un lado les sonaba convincente la mayor educación de las mujeres, por otro no dejaban de perturbarse por la posibilidad de la insurgencia femenina, de disgustarse con la idea de que se reclamara un límite a las mandas hogareñas.

La Voz de la Mujer responde a la nueva corriente que se abre paso entre los fragores de la modernidad productora de un tendal de despojados. Las clases proletarias constituyen la piedra de toque de las formulaciones doctrinarias anarco-comunistas, sin duda uno de los cauces de las configuraciones anarquistas. En estas -que heredan el compromiso de no abdicar jamás de la soberanía individual, impidiendo cualquier representación vicaria- hay corrientes que sostienen la primacía de una sociedad igualitaria, de un régimen absolutamente paritario en el disfrute de los bienes, donde no haya desigualdades más allá de las diferencias que "por naturaleza" tienen los individuos. Bakunin y Kropotkin, con sus matices, han abonado la conquista de un régimen social que elimine la apropiación particular de la riqueza, el Estado y el orden jurídico que lo sostiene. Desde luego, deben desparecer otras fuentes sustantivas de poder, como la Iglesia católica y las instituciones conservadoras. El anarco-comunismo pudo tener antecedentes nativos en algunas ideaciones socialistas románticas, pero no escapa que su empinamiento fue obra de las poblaciones inmigrantes, sobre todo de españoles, italianos y franceses. Las expresiones libertarias se extendieron notablemente desde la última década del XIx y tuvieron mayor aceptación entre los sectores asalariados de menor calificación. No es difícil, como alguna vez sostuve, que para las masas desarraigadas y con evidente exclusión el anarquismo fuera una verdadera ancla, ya que hacía sentido su apotegma de negatividades: "Ni dios, ni patria, ni patrón". El escenario local fue pródigo en la recepción de notables figuras del anarquismo internacional antes de la virada del siglo, tales los casos de Ettore Mattei, Pietro Gori y Errico Malatesta, y si durante un cierto lapso se discutió duramente si se apegaba o no el pensamiento anarquista a la organización sindical y social, finalmente ganó la posición de quienes abogaban por la creación de organizaciones para llevar adelante las luchas proletarias.

Entre las filas libertarias, la cuestión de la mujer tuvo un singular empinamiento, resultó un término fundamental para la demolición del orden social burgués y la extinción de la potestad eclesiástica. Las luchas reivindicativas de las mujeres para conquistar derechos y emancipación gozaban de expresiva ampliación a fines del xix, momento en que además se acuñó el término "feminismo" gracias a la destacada militante francesa Hubertine Auclert. Pero para el anarquismo, desde luego para las anarquistas, la procura de derechos formales resultaba una 
contradicción en sus términos dada la piedra angular de la antilegalidad de su ideario. De modo que la aparición de La Voz de la Mujer, coincidiendo con el surgimiento del Partido Socialista en nuestro país -primero en incluir en su programa el derecho al sufragio femenino-, no puede verse sin más como una contribución al cauce principal del feminismo argentino, aunque debe admitirse que hay allí un atajo -como lo hace Maxine Molyneux en el artículo que vuelve a publicarse en esta edición, y que desde su título mismo expresa la existencia del "feminismo anarquista"-. Por mi parte, he preferido la coligación temeraria de la fórmula "el contrafeminismo del feminismo anarquista" ${ }^{5}$ para dar cuenta del contraste insalvable con las dos principales dimensiones de la agenda feminista desde el siglo xIx hasta mediados del xx: igualdad jurídica y sufragio. Pero no hay dudas de que las mujeres anarquistas se empeñaron, en lo interno de sus propias filas, en acciones por el reconocimiento de su condición de subalternas, por la revolución doméstica y por el control de la fecundidad. Este último aspecto concitó la adhesión de la gran mayoría de los varones anarquistas, y desde fines del xIX -y sobre todo en las primeras décadas del $\mathrm{xx}$ - hubo una maciza contribución de plumas anarquistas destinadas a proclamar la "maternidad consciente", a inducir a sus seguidores a limitar los nacimientos, y los orígenes de estas posiciones deben encontrarse en la adhesión anarquista a las tesis malthusianas y también a la eugenesia. En efecto, había sido Malthus el sostenedor de que la población crecía más rápidamente que los recursos, por lo que había que reprimir (de diferente manera, hasta con la abstención sexual...) la fecundidad. Y por su parte, las posiciones seudocientíficas eugenésicas proclamaban que la raza humana estaba en peligro con la procreación indebida de las personas débiles, enfermas o "desviadas". Debe decirse que el anarquismo mantuvo el ideal de la "eugenesia positiva" pues había que posibilitar condiciones de salud y de bienestar al proletariado para que la especie humana no se deteriorara. Como fuere, las militantes anarquistas estuvieron en la primera leva de las reivindicaciones para controlar la natalidad, sostuvieron que no había que obligarse a la maternidad, fueron las primeras en alentar la adopción de técnicas anticonceptivas, sus más entusiastas propagandistas. Como se puede concluir, una verdadera anticipación de cuestiones que el feminismo sostendría décadas más adelante.

Las preocupaciones de los varones anarquistas por la condición de las mujeres tienen un correlato fundamental en la necesidad de hacerlas

\footnotetext{
${ }^{5}$ Barrancos, Dora, Anarquismo, educación y costumbres en la argentina de principios de siglo, Buenos Aires, Contrapunto, 1992.
} 
partícipes de las luchas emancipatorias, en retirarlas de la influencia del cura, en hacerlas sostenedoras de los combates de los cónyuges, para que no se interpusieran vacilaciones ni detenimientos. Pero si esto es un presupuesto, debe admitirse que en La Voz de la Mujer resulta hegemonizada, y con mayor radicalidad, la crítica a las costumbres del matrimonio legalizado, la propaganda de la sustitución de los falsos intereses y la proclama reiterada del amor libre, única forma amatoria que puede revocar los acuerdos cuando se extinguen los sentimientos. Esta fórmula de enfrentamiento a la hipocresía de los vínculos maritales forzados por la juridicidad será la acostumbrada y casi solitaria semántica anarquista de la época. Pero como sostienen Maxine Molineux en su abordaje, y Laura Fernández Cordero, ${ }^{6}$ sorprenden las expresiones del lenguaje en los primeros números de la publicación. No hay metáforas para dar cuenta de fenómenos como el coito y la masturbación. Es cierto que también hay locuciones que no obvian las concepciones de la moral conforme a la Naturaleza. Era arquetípica la reverencia a esta última, lo que impregnó de fórmulas restrictivas a sus propios discursos libertarios, como surge de la idea de "fraude" con relación a ciertos actos sexuales, seguramente porque se realizaban "contra natura". Pero debe insistirse sobre la disrupción que produce el periódico, de tal manera que termina habiendo una fuerte repulsa entre los acólitos disgustados por la osadía de las notas. Las/los/les lectores actuales podrán observar los cambios significativos de tópicos y de acentos a medida que se editan los nuevos números, por cierto morigerados. Hubo al menos en tres oportunidades cambios del grupo editor, y quiénes lo constituyen en cada oportunidad es todavía materia de interrogantes.

¿Quiénes fueron finalmente las/los editores, y quiénes las emisoras femeninas de La Voz de la Mujer? Si al principio figura Josefa Calvo como responsable -de la que lamentablemente nada se sabe-, no es posible identificar a A. Barcla, no hay pistas sobre esta figura que se hace cargo de la publicación hasta el final, final acelerado que debe atribuirse a las dificultades económicas para sostenerse, ¿o bien a las diatribas que seguía provocando? Algunas notas son firmadas por seudónimos femeninos, como Luisa Violeta, otras por nombres que suenan verdaderos, como Esther Buscaglia, a quien no hemos encontrado en la vasta producción de periódicos anarquistas del período. Tampoco aparece en la lista de deportados por la aplicación de Ley de Residencia, ${ }^{7}$ con la que el Estado

${ }^{6}$ Fernández Cordero, Laura, Amor y anarquismo. Experiencias pioneras que pensaron y ejercieron la libertad sexual, Buenos Aires, Siglo XXI, 2017.

${ }^{7}$ La Ley de Residencia N ${ }^{\circ} 4144$-o Ley Cané- fue sancionada en 1902 y derogada en 1958. Permitía que el Poder Ejecutivo ordenara "la salida del territorio de la Nación a 
argentino quiso reprimir las movilizaciones sociales expulsando a pestíferos agitadores. Unas líneas aparte merece quien se escuda bajo el seudónimo de Pepita Gherra, ¿qué conjeturas formular? No es posible desentrañar en el estado actual de las investigaciones la identidad de Pepita... aunque podemos seguir apostando a que correspondía a un sujeto femenino. Aunque parezca más arduo, es sin embargo más plausible hacernos una idea acerca de quiénes leyeron La Voz de la Mujer. María del Carmen Feijóo y Marcela Nari ${ }^{8}$ hicieron una incursión tratando de identificar a las posibles lectoras del periódico -también a los lectores-, y concluyeron que fueron probablemente trabajadoras, obreras de la confección, "fabriqueras", mucamas, pero también muchas debieron ser solo amas de casa en hogares muy modestos, en los que se encendía la chispa de la contestación frente a tantas inequidades. Pero las autoras señalan las dificultades de aproximación efectiva con esas mujeres debido a lo ciertamente abstruso de las cuestiones en debate y también a las dificultades en la operación de leer. Debe pensarse que solo la mitad de las habitantes mujeres en la ciudad de Buenos Aires eran alfabetizadas, y que la enorme mayoría de las españolas e italianas que ingresaron a nuestro país en ese ciclo que va desde fines del xix hasta alrededor de 1913 eran analfabetas. Pero no hay dudas de que la proximidad con el ideario anarquista suscitaba esfuerzos para saber leer y escribir, y se debe a la corriente una saga singular de emprendimientos educativos, que alcanzaron a no pocas mujeres.

Volver a las fuentes del pasado, llenas de imprecaciones acerca de la indigna existencia que resulta de un orden social injusto, y en las que relampaguean retos al autoritarismo patriarcal, a sus sometimientos, tiene sentido angular si se interpelan las continuidades en el presente. Es con los ojos puestos en el tiempo presente como volvemos al pasado. Redoblamos la apuesta a una sociedad sin patriarcado, sin discriminaciones ni exclusiones de ninguna índole; al final, una conjura que estuvo en buena medida asociada a esa empresa irreverente que fue La Voz de la Mujer.

\section{Dora Barrancos}

todo extranjero que haya sido condenado o sea perseguido por los tribunales extranjeros por crímenes o delitos comunes" (art. 1). También podía determinar "la salida de todo extranjero cuya conducta comprometa la seguridad nacional o perturbe el orden público" (art. 2). Fue reiteradamente empleada contra extranjeros sindicados como peligrosos para la seguridad nacional.

${ }^{8}$ Feijoó, María del Carmen y Marcela Nari, "Imaginando el lector / la lectora de La Voz de la Mujer", en Fletcher, Lea (comp.), Mujeres y cultura en el siglo xIx, Buenos Aires, Feminaria, 1994. 
El periódico La Voz de la Mujer que hoy edita la Editorial de la Universidad Nacional de Quilmes tuvo un destino compartido con buena parte de las fuentes para el estudio de la historia obrera, en un país que no ha sido especialmente cuidadoso en la conservación de su pasado y en el que esta conservación dependió, en muchos casos, de los esfuerzos aislados y personales de grupos y militantes dispersos. Publicado en el año 1897, en el contexto de la oleada de literatura socialista y anarquista del fin de siglo, desapareció por completo de los repositorios nacionales y de la memoria colectiva. Reaparece fugazmente en la prolija recopilación que, en ocasión del concurso convocado con motivo de cumplirse el cincuentenario de la aparición de La Protesta, se realizó en Buenos Aires en el año 1927, y que se conoce como el Certamen Internacional de La Protesta. En dicha publicación es Max Nettlau quien consigna su existencia en la ponencia denominada "Contribución a la bibliografía anarquista de la América Latina hasta 1914", incluyéndolo en el ciclo de los periódicos de propaganda general aparecidos entre 1890 y 1904 en la Argentina. Sin disponer de los mismos en el momento de la elaboración de la nota, Nettlau brinda un consejo aún válido frente a nuestra orfandad en materia de fuentes-:

He visto y a menudo leído, los periódicos de los que voy a dar la lista, pero ya hace mucho tiempo de esto, y aunque conservo muchas impresiones, éstas carecen de frescura, son incompletas y no vale la pena de recargar con ellas estas listas. Son los militantes que tienen un recuerdo vivo de cada periódico, los que harán bien -si quieren servir a la historia- en perfilar en pocas palabras la fisonomía de cada periódico y de los detalles dignos de ser conservados que a ellos se refieren, y los estudiosos de espíritu crítico, al hojear esas colecciones, sacarán a la luz las ideas, críticas, descripciones sociales y otros materiales vivientes que duermen en los viejos periódicos.

Es sólo en 1978 cuando el libro de Iaäcov Oved, El movimiento anarquista en la Argentina, en su bien documentado anexo, así como en el texto, reitera la referencia a $L a$ Voz de la Mujer, resguardado en la biblioteca del 
Institute of Social History de Amsterdam, junto con otras tantas fuentes indispensables para la tarea de reconstruir las voces olvidadas y escondidas de los sectores populares. Este rescate facilita la consolidación de una nueva manera de abordar la historia, a la luz de nuevas fuentes y testimonios que brillan por sí mismos pero que, a la vez, obligan a la relectura de lo que ya se conocía. Por ejemplo, a la búsqueda de una lectura de la historia que intersecte la condición de clase con la condición de género. Por último, en el año 1986 el artículo de Maxyne Molyneux, también incluido en esta edición, aborda sistemáticamente la descripción y el análisis del corpus del periódico.

Al publicar ahora la fuente, junto con el mencionado artículo, se pone al alcance del público interesado en la historia feminista y en la de los sectores subalternos un material cuya riqueza podrá explorarse en profundidad, como un texto específico y en términos de sus cruces con la ideología y las prácticas organizativas del período. Al publicarla, también, la Editorial de la Universidad Nacional de Quilmes realiza una contribución para la recuperación de la memoria colectiva y, como lo quería Max Nettlau, cumple con el mandato de "servir a la historia".

María del Carmen Feijoó 


\section{PRESENTACIÓN}

Ni Dios, ni Patrón, ni Marido

Feminismo anarquista en la Argentina del siglo XIX

Por Maxine Molyneux*

Este artículo analiza el feminismo anarquista, una tendencia dentro del movimiento anarquista del siglo XIX en la Argentina, a través de un estudio del contenido y el contexto social del periódico La Voz de la Mujer. Hay dos razones principales para estudiar este fenómeno. La primera de ellas es familiar a la historiografía feminista: volver visible lo que, en la frase de Sheila Rowbotham (1974), ha permanecido "oculto para la historia". La historia del feminismo anarquista en la Argentina nunca ha sido escrita; ni siquiera ha sido reconocida como una tendencia distintiva dentro del movimiento anarquista o de los movimientos latinoamericanos de mujeres. Los principales historiadores del anarquismo argentino -Max Nettlau, Diego Abad de Santillán e Iaäcov Ovedapenas si notan la existencia de $\mathrm{La}$ Voz, sin analizar su contenido ni explorar su relevancia.

Una segunda razón concierne a las implicaciones políticas de tales fenómenos en el interior del debate feminista, especialmente en el contexto del tercer mundo. La Voz de la Mujer era un diario escrito por mujeres para mujeres, y sus redactoras sostenían que era el primero en su tipo en Latinoamérica. Aunque esto no era cierto, ${ }^{1} \mathrm{La}$ Voz podía alegar originalidad en su carácter de expresión independiente de una corriente explícitamente feminista dentro de los movimientos de los trabajadores del continente. Siendo uno de los primeros casos registrados en Latinoamérica de una fusión de ideas feministas con una orientación revolucionaria y trabajadora, difiere del feminismo hallado en otros lugares de

${ }^{*}$ Maxine Molyneux es profesora de Sociología en el Institute of The Americas <www. ucl.ac.uk/americas>. Correo electrónico: <m.molyneux@uel.ac.uk>. El presente artículo apareció previamente en la revista Latin American Perspectives, Issue 48, vol. 13, Nº 1, 1986, pp. 119-145. La autora desea agradecer al Instituto de Historia Social en Amsterdam, y a I. Oved por haber llamado su atención acerca de la existencia de La Voz de la Mujer.

${ }^{1}$ O Jornal das Senhoras, por ejemplo, apareció en el Brasil en 1852. Estaba dedicado a "el adelanto social y la emancipación moral de las mujeres" (Hahner, 1978). 
Latinoamérica durante las fases iniciales de industrialización. Este último solía centrarse en mujeres educadas de clase media y reflejaba, en cierto grado, sus preocupaciones específicas. En el contexto latinoamericano, en el cual el feminismo es frecuentemente despreciado por los grupos radicalizados como un fenómeno "burgués" o "reformista", el ejemplo de La Voz constituye un cuestionamiento a este modo de caracterizar lo esencial del movimiento. Aunque la investigación empírica no puede ser el terreno exclusivo para el debate acerca de la naturaleza y la efectividad del feminismo, una consideración de los hechos puede proveer información a dicho debate.

\section{El contexto}

El feminismo anarquista surgió en Buenos Aires en la década de 1890 en un contexto modelado por tres factores que distinguían a la Argentina entre los estados latinoamericanos del siglo XIX: un crecimiento económico rápido, el flujo de grandes números de inmigrantes europeos, y la formación de un movimiento laboral activo y radical. Durante la segunda mitad del siglo xix, la economía argentina estaba pasando por un momento de expansión espectacular. En el período comprendido entre 1860 y 1914, las tasas de crecimiento real del PBI estaban entre las más altas del mundo, lo que otorgaba a la Argentina un liderazgo sobre el resto de Latinoamérica, que iba a ser retenido hasta los años sesenta. La base de esta expansión era la explotación de las fértiles pampas, las infinitas llanuras del interior, las cuales producían trigo y carne baratos para los mercados europeos. Como la demanda de estos productos creció, y la capacidad productiva argentina se incrementó, el área de tierra cultivada se elevó de aproximadamente 80.000 ha en 1862 a 24 millones en 1914 (Ferns, 1960).

El crecimiento de la economía incrementó la demanda de trabajo, y ésta fue satisfecha por la inmigración en gran escala. Desde la década de 1870 en adelante, se abrieron oficinas especiales en Italia, España, Francia y Alemania para atraer a los inmigrantes a la Argentina, con la promesa de tierras baratas, pasajes y préstamos. La respuesta en las áreas deprimidas de Europa fue extraordinariamente positiva, y la tasa de inmigración alcanzada no tuvo comparación con la de ningún otro lugar en el subcontinente. En total, entre 1857 y 1941, momento en que la inmigración había casi cesado, más de 6,5 millones de personas migraron a la Argentina, y cerca de 3,5 millones permanecieron allí. En 1914 la Argentina era el país con la más alta proporción de inmigrantes con 
respecto a la población indígena en el mundo. ${ }^{2}$ Desde 1857 a 1895 , la Argentina había recibido 2.117 .570 extranjeros, de los cuales 1.484.164 se establecieron. En 1895, éstos representaban el 20\% de los aproximadamente 4.000.000 de habitantes de la Argentina, y el 52\% de la población de Buenos Aires, la ciudad capital (Solberg, 1970).

El mayor grupo étnico estaba compuesto por italianos, quienes en 1895 representaban el 52\% del número total de inmigrantes. Los españoles conformaban el segundo grupo más grande, con el 23,2\% del total, y los franceses representaban el 9,6\%. Pequeños porcentajes de alemanes, británicos, austríacos, uruguayos, árabes, suizos y europeos del este integraban el resto. Fue entre estas comunidades de inmigrantes que el grupo que produjo La Voz de la Mujer surgió y desplegó su actividad. El anarquismo como ideología política fue originalmente importado por los inmigrantes provenientes de los países europeos en los cuales el movimiento anarquista era fuerte -Italia, España y Francia-. ${ }^{3}$ Los grupos y las publicaciones anarquistas, muchos de los cuales fueron fundados por refugiados políticos de Europa, emergieron por primera vez en las décadas de 1860 y 1870.

A pesar de los orígenes foráneos del anarquismo, no hay duda de que las condiciones materiales que encontraron los inmigrantes en la Argentina proveyeron un terreno fértil para el mismo. Tras su arribo a Buenos Aires, aproximadamente la mitad de los inmigrantes buscó inicialmente su fortuna en la tierra, mientras que el resto encontró trabajo en la economía portuaria en expansión y en otros centros urbanos tales como Rosario y La Plata. Se convirtieron en jornaleros, obreros, empleados domésticos y empleados públicos en los proyectos de construcción financiados por el Estado. Mientras que algunos tenían capital para invertir en negocios y en bienes raíces, la mayoría eran miembros de la clase trabajadora rural o urbana, que habían venido a la Argentina para escapar de las privaciones de sus propios países y lograr fortuna.

Pocos inmigrantes lograron alcanzar la movilidad social a la que aspiraban. La mayoría continuaron siendo trabajadores; aproximadamente el $70 \%$ de los inmigrantes se concentraron en la ciudad de Buenos Aires, y

${ }^{2}$ En la víspera de la Primera Guerra Mundial, el 30\% de la población argentina era inmigrante, en contraste con el 14\% de la población de los Estados Unidos en 1910 (Solberg, 1970).

${ }^{3}$ Había, desde luego, corrientes anarquistas nativas en la Argentina -formas de resistencia popular espontánea-, pero eran incapaces de alcanzar una expresión organizacional estable. Una de ellas, conocida como cultura gauchesca, se convirtió en tema central de dramaturgos y poetas anarquistas desde 1890 en adelante (véase Franco, 1963, y Yunque, 1941). 
de la clase trabajadora en general alrededor del 60\% eran extranjeros. El deseo frustrado de una mejora en sus medios de vida fue probablemente una de las causas principales del descontento de los inmigrantes (Rock, 1975). Para muchos de estos trabajadores, las condiciones eran desastrosas. En Buenos Aires, donde la población se duplicó entre 1869 y 1887, y nuevamente entre 1887 y 1904 , la vivienda era escasa y de mala calidad. Muchos trabajadores vivían en conventillos, en los cuales la familia inmigrante promedio de cinco personas compartía una habitación de $12 \times 12$ pies (3,6 x 3,6 metros, aproximadamente) (Solberg, 1970). Aunque los salarios no eran bajos en comparación con los de otros países latinoamericanos, se deterioraban a causa de las constantes devaluaciones. Los trabajadores eran estafados frecuentemente en los tratos con sus jefes, y las condiciones de empleo eran duras. La norma era una jornada de diez horas y una semana laboral de seis días (Marotta, 1960).

Las dificultades materiales se combinaban con condiciones políticas que no aliviaban en lo más mínimo la distancia de los inmigrantes respecto de la realidad argentina, y su insatisfacción ante ella. Aunque en teoría la Argentina tenía un gobierno constitucional en el cual prevalecía la soberanía popular, en la práctica existía un sistema de elección indirecta, clientelismo político y alianzas informales con caudillos locales. Esto anulaba la representatividad política real de la mayoría de los residentes argentinos, fueran nativos o inmigrantes. Cuando los inmigrantes comenzaron a hacerse oír, y la militancia de la clase trabajadora aumentó, los inmigrantes parecieron amenazar la prosperidad económica que ellos habían ayudado a construir. Para aumentar el control sobre ellos, el gobierno hizo casi imposible la naturalización de los inmigrantes, aunque sus hijos se consideraban ciudadanos argentinos por derecho de nacimiento. No es sorprendente, por lo tanto, que en 1895, de un total de 345.493 extranjeros en Buenos Aires, sólo 715 habían adquirido la ciudadanía (Bourdé, 1974).

Esta política de restricción de derecho al sufragio permitió que el gobierno pospusiera algunas de las consecuencias de la inmigración durante dos décadas. La población inmigrante fue mantenida en una situación económica y política precaria. La doble descalificación (electoral y nacional) que permitía una expresión política mínima de sus aspiraciones la alentó a expresarse de un modo combativo y, muchas veces, revolucionario. El descontento de los inmigrantes fue evidente en las huelgas de finales de la década de 1880, y alcanzó un pico en la huelga general de 1902. Pero el gobierno estaba obligado a continuar creando la fuerza misma que deseaba contener.

Las comunidades inmigrantes, que integraban la naciente clase trabajadora, tenían un rol prominente en el modelado de sus ideologías y del 
carácter de sus luchas. Ellas trajeron de Europa una cultura política que emergió a partir de su experiencia con las organizaciones y las formas de acción de la clase trabajadora, trasladando los debates acerca del anarquismo, el socialismo y la organización de los sindicatos a las tiendas, los conventillos y los cafés de Buenos Aires, Rosario y La Plata. La primera huelga, en 1878, fue organizada por el Sindicato de Prensa, establecido 20 años antes por cooperativistas españoles. Para la década de 1880 se habían extendido las formas de organización y de resistencia de la clase trabajadora, y este crecimiento se aceleró por el inicio de una recesión severa, conocida como la crisis Baring, que azotó a la Argentina entre 1889 y 1891. El colapso económico precipitó una crisis gubernamental, un levantamiento por parte de los militantes del naciente partido Radical, y la primera ola extendida de acción huelguista, al final de la cual había pocas ramas del empleo que hubieran escapado a los efectos del descontento de los trabajadores.

En este clima de creciente militancia de la clase trabajadora, en las décadas de 1880 y 1890, había grupos revolucionarios activos que producían panfletos y diarios, organizaban mítines masivos, presentaban obras de teatro y participaban en huelgas y manifestaciones. Hasta la emergencia del Partido Socialista como una fuerza significativa a fin de siglo, gran parte de estas actividades eran llevadas a cabo por anarquistas, muchos de los cuales, como Ettore Mattei y Enrico Malatesta, eran exiliados de Europa. Contaban con un apoyo importante en la clase trabajadora y controlaban un número significativo de sindicatos poderosos, entre los cuales se encontraba el de los panaderos (organizado por Mattei) y el de los albañiles. En las décadas de 1880 y 1890 llegaron a existir hasta 20 diarios anarquistas simultáneamente en francés, español e italiano; ocasionalmente aparecían artículos en cada uno de esos idiomas en el mismo diario.

El anarquismo en la Argentina alcanzó su pico en las primeras dos décadas del siglo $\mathrm{xx}$, y la historia anterior de este movimiento puede ser vista como un avance lento y muchas veces interrumpido hacia este clímax. La Voz de la Mujer apareció después de medio siglo de continua y tentativa actividad anarquista, y como una de las primeras expresiones de lo que llegaría a ser el anarquismo argentino en su mejor momento.

Las fluctuaciones del anarquismo y las formas de organización y lucha adoptadas seguían un modelo similar al europeo, y por la década de 1890 el anarquismo se encontraba, como en cualquier otro lado, sobre todo bajo la influencia del comunismo anarquista propagado por Piotr Kropotkin y Elysée Reclus en Europa, y Emma Goldman y Alexander Berkmann en los Estados Unidos. Ésta era la tendencia a la que pertenecía La Voz 
de la Mujer. El comunismo anarquista era una fusión de ideas socialistas y anarquistas. Estaba orientado hacia la eliminación violenta de la sociedad existente y hacia la creación de un orden social nuevo, justo e igualitario, organizado sobre el principio de: "De cada uno, según sus fuerzas; a cada uno, según su necesidad". Internacionalmente, el movimiento estaba dividido en cuanto a si la revolución debía ocurrir a través de un levantamiento popular, o a través de una huelga masiva. Había también desacuerdos acerca de la medida en la cual el movimiento anarquista mismo debía estar organizado, y acerca de las formas apropiadas de emplear actos de violencia individual en contra del Estado, con propósitos de propaganda. Tanto el socialismo como el anarquismo se centraban en la clase trabajadora, pero también expresaban cierta simpatía por el principio de la emancipación de la mujer. Para la década de 1880, había surgido una corriente feminista distintiva en el seno del movimiento anarquista europeo, representada por escritoras tales como "Soledad Gustavo" (Teresa Mañe) y Teresa Claramunt, de modo similar a como en el movimiento norteamericano estas ideas eran desarrolladas por Voltairine de Cleyre, Emma Goldman y otras. Algunas de estas escritoras ya estaban siendo publicadas en la Argentina en la década de 1880, y en las críticas a la familia de la prensa anarquista aparecieron junto a editoriales apoyando al "feminismo", que era un término de uso común en ese momento. El mayor impulso al feminismo anarquista provino de los activistas españoles, pero exiliados italianos como Malatesta y Pietro Gori apoyaron las ideas feministas en sus diarios y artículos.

En las décadas de 1880 y 1890, una de las principales formas de la actividad anarquista era la edición, impresión y distribución de diarios, folletos y panfletos. Más aún, había aparentemente tanta literatura anarquista circulando en Buenos Aires en los últimos años del siglo como en el bastión anarquista de Barcelona (Solberg, 1970). En los primeros años, la mayor parte del contenido editorial de estos diarios era importado de Europa, pero a medida que se ganó experiencia los contenidos reflejaron, cada vez más, un compromiso local.

Se sabe muy poco acerca acerca de cómo se financiaban estos emprendimientos editoriales, pero según la información disponible parece ser que algunos fondos llegaban en forma de pequeñas donaciones recolectadas en mitines y conferencias. Los costos de impresión eran relativamente bajos; de acuerdo con las listas que aparecían al final de las publicaciones, el costo de publicación de las dos mil copias de un diario era, en la región, de \$ 45 en 1897 -un poco más del doble del salario semanal-. Las listas de suscripción muestran que por lo general las donaciones individuales eran de aproximadamente 20 centavos; tres o cuatro grupos, algu- 
nos en las provincias, enviaban regularmente sumas de hasta cinco pesos cada uno. Los donantes eran generalmente identificados por nombres falsos, que evocaban noms de guerres (como "Firme en la Brecha", "Menos Pedir, Más Tomar", "Un Tirabombas"), u oficios; los miembros de este último grupo, el cual incluía a los zapateros, barrenderos, prostitutas, camareros y conductores, junto con las pequeñas sumas donadas, indican la clase social de los lectores. ${ }^{4}$ Los panfletos y los diarios eran frecuentemente regalados. Debido a la irregularidad con la que aparecían estos diarios, y a la precariedad de su existencia, la institución de una suscripción regular no era efectiva.

La Voz de la Mujer era uno de los típicos diarios pequeños, semiclandestinos y efímeros de la tendencia comunista-anarquista, que reivindicaba la "propaganda por los hechos". A pesar de estar dirigido a la clase trabajadora, parecía tener pocos lazos orgánicos con ella, y su actitud antirreformista militante debilitaba más su capacidad de intervención política en la problemática contemporánea. Sin embargo, su feminismo debió haber provocado alguna respuesta entre las mujeres trabajadoras en las ciudades de Buenos Aires, La Plata y Rosario, ya que duró un año y se imprimieron entre mil y dos mil copias de cada edición -un número respetable para un diario anarquista en ese momento.

Fue entre las mujeres trabajadoras de los centros urbanos que La Voz de la Mujer surgió y luchó por apoyo. Las redactoras surgieron de las grandes comunidades española e italiana, y se identificaban a sí mismas con las mujeres de la clase trabajadora. Había, seguramente, un público de mujeres de la clase trabajadora urbana en la Argentina del siglo xIx, y muchas de estas mujeres eran inmigrantes. El censo de 1895 reportó 368.560 mujeres inmigrantes (un poco más que la mitad del número de hombres, aunque las mujeres constituían la mayoría de la población nativa), el 37\% de las cuales estaban en Buenos Aires. No sabemos qué porcentaje de este total eran trabajadoras, pero las mujeres inmigrantes constituían la mayoría de la población económicamente activa de Buenos Aires y sumaban el $40 \%$ de los 21.571 empleados domésticos, el 66,1\% de las modistas, el $56,9 \%$ de las costureras, el 16,9\% de las cocineras, el $23 \%$ de las maestras, y el $34 \%$ de las enfermeras. En total, las mujeres inmigrantes constituían aproximadamente la mitad de las 66.068 mujeres registradas como empleadas en la capital, y se concentraban en el servicio doméstico, las industrias de la costura y textil, y en la cocina (Segundo censo, 1898).

${ }^{4}$ Desafortunadamente, hay muy pocas listas como para dibujar un retrato exacto. Oved (1978) argumenta que en la Argentina, como en otros lugares, el apoyo al anarquismo se encontraba entre los trabajadores no calificados y semicalificados. 
Esta tasa relativamente alta de participación, acompañada con iguales oportunidades para las niñas en su educación, significaba que la prensa radical tenía un grupo potencial de lectores que no se confinaba a las clases bajas. La Voz de la Mujer podía contar también con la existencia de un número bastante grande de mujeres alfabetizadas y con al menos alguna educación entre las trabajadoras a las cuales dirigía su propaganda. Las mujeres inmigrantes más pobres, sin embargo, no solían tener educación alguna. Estas mujeres inmigrantes estaban generalmente unidas, en carácter de esposas o madres, a sus esposos y familias, si bien muchas de ellas deben haber sufrido los problemas comunes asociados con el desorden y la adaptación a una cultura ajena, aunque algo aliviados por la continuidad en el lenguaje y los valores religiosos. Para las mujeres, la migración, sea interna o internacional, era al mismo tiempo un efecto como una causa de cambios en la familia y en su posición en la sociedad. En tanto la estructura socioeconómica del viejo mundo se descomponía, se redefinían las relaciones en el interior de la familia y, en algunos grupos, se liberalizaban. Sin embargo, parecería que la mayor parte de las mujeres inmigrantes permanecieron entrampadas dentro de sus propias culturas comunales en lo relativo a las cuestiones de sexualidad y familia, y que las tradiciones y prejuicios de la Europa meridional continuaron ejerciendo influencia. A pesar de las condiciones tumultosas de la capital en este período, las mujeres fueron mantenidas en sus roles sociales y económicos tradicionales y obligadas a trabajar bajo las estructuras discriminatorias que prevalecían en otros puntos del mundo industrializado. La Voz de la Mujer, por lo tanto, surgió en el contexto de la descomposición y recomposición de las divisiones de rol tradicionales.

Lo distintivo de La Voz de la Mujer como periódico anarquista radicaba en su reconocimiento de la especificidad de la opresión de las mujeres. Convocaba a las mujeres a movilizarse contra su subordinación como mujeres, al igual que como trabajadoras. Su primer editorial consistió en un rechazo apasionado del destino de las mujeres:

\footnotetext{
Compañeros y Compañeras ¡Salud!

Y bien: hastiadas ya de tanto y tanto llanto y miseria, hastiadas del eterno y desconsolador cuadro que nos ofrecen nuestros desgraciados hijos, los tiernos pedazos de nuestro corazón, hastiadas de pedir y suplicar, de ser el juguete, el objeto de los placeres de nuestros infames explotadores o de viles esposos, hemos decidido levantar nuestra voz en el concierto social y exigir, exigir decimos, nuestra parte de placeres en el banquete de la vida.
} 
La aparición de este número recibió una respuesta dispar del resto del movimiento anarquista, que iba desde el silencio y la hostilidad hasta el elogio. El Oprimido, editado por un afable inglés llamado Dr. Creaghe, ${ }^{5}$ extendió una bienvenida particularmente cálida en su número de noviembre de 1895 (?):
Al darle este nombre, un grupo de mujeres militantes ha desplegado la bandera roja de la anarquía y se propone publicar una revista para reali- zar propaganda entre aquellas que son sus camaradas tanto en el trabajo como en la miseria. Saludamos a las valientes iniciadoras de este proyec- to, y al mismo tiempo convocamos a nuestros camaradas a apoyarlas.

Una parte importante de la prensa anarquista simpatizaba con los planteos del feminismo en ese momento. A mediados de la década de 1890 se asistía en la Argentina a una cobertura cada vez mayor de temas relativos a la igualdad de las mujeres, y en particular al matrimonio, la familia, la prostitución y la dominación de las mujeres por los hombres. Algunos periódicos incluso publicaron una serie especial de panfletos dedicados a "el problema de la mujer". La Questione Sociale, el periódico en italiano fundado por Malatesta cuando vino a la Argentina en 1883, publicó una serie de panfletos "especialmente dedicados a un análisis de las cuestiones de la mujer", incluyendo escritos de "Soledad Gustavo" acerca de las mujeres y la educación, y de los sufrimientos de las mujeres pobres y proletarias. Estos dos panfletos fueron lo suficientemente bien recibidos como para ser reimpresos; el segundo requirió una edición de 4.000 ejemplares. La Editorial Ciencia y Progreso, un emprendimiento del Dr. Creaghe ligado a La Questione Sociale, también lanzó numerosos panfletos acerca de las mujeres, incluyendo los textos de una serie de conferencias dictadas por el "Dr. Arana" en la provincia de Santa Fe. Ellos incluyeron una disertación de 87 páginas basada en la obra de Morgan llamada La Mujer y la Familia, publicada en 1897, y un trabajo menos extenso titulado Esclavitud Antigua y Moderna, que incluía entre sus ejemplos de este último tipo de esclavitud la institución del matrimonio. Estos panfletos se imprimieron originalmente en ediciones de 500 ejempla-

\footnotetext{
${ }^{5}$ Mencionado en la revista literaria Caras y Caretas, 1901. Según Abad de Santillán (1930), Creaghe era "muy querido" por el movimiento anarquista argentino. Según parece, antes de abandonar Gran Bretaña había sido un miembro activo del movimiento de los trabajadores de Sheffield, donde había publicado una revista llamada El Anarquista de Sheffield.
} 
res, pero fueron reimpresos tres veces antes de fin de siglo, indicando un interés considerable en el tema. Ruvira (1971) nota que los primeros grupos de mujeres que emergieron en 1895 eran adherentes de La Questione Sociale y que fueron estos grupos los que produjeron las "militantes reales": "Pepita Gherra", Virginia Bolten, Teresa Marchisio, Irma Ciminaghi y Ana López.

El periódico Germinal, que apareció por primera vez en 1897, estaba, al igual que El Oprimido, particularmente preocupado por "el problema de la mujer"; contenía varios artículos en una sección que llevaba por título "Feminismo", y defendía "el carácter extremadamente revolucionario y justo del feminismo", contra la acusación de que era meramente una creación de "señoritas elegantes". Mucho, si no todo, el material feminista de la prensa argentina parece haber sido escrito por mujeres, aunque es imposible verificar esto ya que el uso de seudónimos era una práctica común. La Voz de la Mujer gozaba de cordiales relaciones con al menos algunos de sus contemporáneos, particularmente aquellos que pertenecían a la tendencia más extrema de propaganda-por-los-hechos, como El Perseguido y La Voz de Ravachol. También tenía relaciones con los periódicos españoles El Esclavo, La Voz del Rebelde y El Corsario, con el periódico de Nueva York El Despertar, y con el periódico uruguayo Derecho a la Vida.

Sin embargo, esta aparente simpatía, en principio, por el feminismo, fue acompañada por una oposición sustancial en la práctica. El primer número de La Voz de la Mujer parece haber provocado una hostilidad considerable, ya que en el número siguiente las redactoras atacaban las actitudes antifeministas predominantes entre los hombres del movimiento en términos muy claros. (Dado que no parece haber signos de esta oposición en el resto de la prensa anarquista del período, es probable que estas críticas hayan sido expresadas oralmente.)

Cuando nosotras (despreciables e ignorantes mujeres) tomamos la iniciativa de publicar La Voz de la Mujer ya lo sospechábamos joh modernos cangrejos! que vosotros recibiríais con vuestra macanística y acostumbrada filosofía nuestra iniciativa porque habéis de saber que nosotras las torpes mujeres también tenemos iniciativa y ésta es producto del pensamiento; ¿sabéis? también pensamos.

Apareció el primer número de La Voz de la Mujer, y claro, jallí fue Troya! "nosotras no somos dignas de tanto, ¡icá! no señor", "¿emanciparse la mujer?" , “ipara qué?" "¿qué emancipación femenina ni que ocho rábanos?”, “¡la nuestra!”, "venga la nuestra primero, y luego, cuando nosotros, los hombres, estemos emancipados y seamos libres, allá veremos". 
Las redactoras llegaban a la conclusión de que difícilmente podrían las mujeres apoyarse en los hombres para tomar la iniciativa al demandar la igualdad para las mujeres, dado este tipo de actitud hostil. ${ }^{6}$

El mismo número del periódico contiene un segundo artículo sobre esta cuestión, titulado "A los escarabajos de la idea". En él se advierte a los hombres: "Es preciso [...] que comprendáis de una vez por todas que nuestra misión no se reduce a criar vuestros hijos y lavaros la roña, que nosotras también tenemos derecho a emanciparnos y a ser libres de toda clase de tutelaje, ya sea social, económico o marital".

Podemos, sin embargo, suponer que la polémica no cesó, porque el editorial del tercer número está dirigido "A nuestros enemigos" y declara que a pesar de la verdadera tempestad que "se ha descolgado sobre La Voz de la Mujer", las redactoras, las que aparentemente han sido llamadas "feroces de lengua y pluma", están aún "firmes en la brecha". Se indica una pequeña concesión, sin embargo, en su preocupación por enfatizar que no estaban atacando a los camaradas anarquistas varones en general, sino solamente a aquellos "falsos Anarquistas" que no defendieron "la emancipación de la mujer, uno de los grandes y bellos ideales de la Anarquía!"

La furia de las redactoras estaba justificada por cuanto el anarquismo abogaba por la libertad y la igualdad de toda la humanidad. Las mujeres, como grupo oprimido, podían con derecho requerir el apoyo de sus compañeros anarquistas en su lucha por la emancipación. Pero aunque los principios del anarquismo habían atraído a muchas mujeres librepensadoras a sus filas y el movimiento ciertamente tomaba al feminismo en serio, había una cierta ambivalencia acerca del estatuto preciso de la lucha por la emancipación de la mujer en sí misma. Las mujeres eran bienvenidas como militantes de "la causa de la anarquía", según lo expresaba El Oprimido, pero se les daba algo menos de apoyo para luchar por las reivindicaciones del feminismo, y ningún apoyo para formar grupos feministas autónomos. La doctrina anarquista misma era algo ambivalente acerca del feminismo, y el debate teórico acerca del tema era notablemente escaso. Aunque Bakunin había incluido en el programa de su Alianza Internacional por la Democracia Social el fin explícito de abolir la desigualdad sexual junto a la desigualdad de clases, los antecedentes anarquistas relativos a los derechos de las mujeres eran desparejos. Los proudhonistas franceses se habían opuesto a las exigencias de las feministas de igual pago e igual trabajo, y pensaban que el lugar natural de las mujeres estaba

${ }^{6}$ En el contexto de España hasta los tiempos de la Guerra civil, esta ambivalencia en la actitud del movimiento hacia el feminismo y los triunfos y fracasos de las mujeres anarquistas es discutida por Kaplan (1971) y Junco (1976). 
en el seno de la familia (Rowbotham, 1974). El principal inspirador del anarquismo-comunismo de las décadas de 1880 y 1890, Kropotkin, alentaba el activismo femenino dentro del movimiento pero desaprobaba el feminismo. Veía a la lucha de la clase trabajadora por la liberación como primaria; los intereses específicos de las mujeres debían ser subordinados al logro de este objetivo.

En la Argentina, cuando los anarquistas comenzaron a recoger algunas de las reivindicaciones prácticas de la clase trabajadora, hacia el fin de siglo, una de sus campañas más vigorosas fue en favor de una legislación protectora de las mujeres. Cuando por primera vez se tomó como consigna el igual pago para las mujeres, lo cual fue apoyado por un número significativo de sindicatos de la Federación Obrera Argentina, en 1901, Pietro Gori, un famoso militante anarquista, planteó que "debería prohibirse que las mujeres trabajen en áreas que podrían ser peligrosas para la maternidad y que podrían socavar su moral; y debería prohibirse totalmente que trabajen los niños menores de 15 años". La preocupación por la moral de las mujeres, y la yuxtaposición de las mujeres y los niños en esta formulación paternalista, son reveladoras. ${ }^{7} \mathrm{El}$ comité votó unánimemente "organizar a las mujeres trabajadoras para que puedan elevar sus condiciones morales, económicas y sociales” (Marotta, 1960).

No es difícil, sin embargo, ver por qué las feministas se sintieron atraídas por el anarquismo. Sus preceptos centrales acentuaban la lucha contra la autoridad, y el feminismo anarquista centraba sus energías en el poder ejercitado sobre las mujeres en el matrimonio y la familia, buscando la libertad de tener relaciones fuera de estas instituciones. El énfasis anarquista en la opresión y las relaciones de poder, aunque no fue teorizado durante mucho tiempo, abrió un espacio dentro del cual las mujeres podían ser vistas simultáneamente como víctimas de la sociedad y como víctimas de la autoridad masculina. Como lo expresaba La Voz de la Mujer en su número 4, "odiamos a la autoridad porque aspiramos a ser personas humanas y no máquinas automáticas o dirigidas por la voluntad de 'un otro', se llame autoridad, religión o con cualquier otro nombre". Una de las adherentes de La Voz de la Mujer reformuló este "cualquier otro nombre" al firmar como "Ni Dios, Ni Patrón, Ni Marido".

${ }^{7}$ A partir del 1900, los estatutos de algunos grupos de trabajadores con fuerte presencia anarquista contienen demandas de igual pago a las mujeres y de abolición del matrimonio. Esta última demanda apareció en las propuestas anarquistas para los estatutos de la Federación Obrera Argentina, la primera federación de trabajadores de la Argentina, pero fue retirada de la lista final de reivindicaciones, probablemente a causa de la oposición socialista (Marotta, 1960). 
Así, el anarquismo, más que el socialismo con su énfasis en la explotación económica, fue capaz de integrar algunos aspectos del feminismo, pero las ideas feministas no encontraron una gran aceptación en sí mismas, sea dentro o fuera del movimiento anarquista. Esta tensión entre el movimiento anarquista como un todo y las feministas que participaban en él se refleja en la trayectoria de La Voz de la Mujer.

Según sabemos, La Voz de la Mujer publicó solamente nueve números. El primer número apareció el 8 de enero de 1896, y el último casi exactamente un año más tarde, el día de año nuevo. Es posible que haya sido reeditado en una fecha más tardía. Las fuentes habituales del movimiento anarquista de este período establecen su existencia durante los años 1896 y 1897 y no nos dicen casi nada acerca de él. Los editoriales refieren tres cambios en los responsables de la publicación, pero no se menciona ningún nombre. Sin embargo, en un número de la revista Caras y Caretas publicado en 1901 se menciona a las "dos hermosas mujeres que publican La Voz de la Mujer". Se alude a una actriz, de la que no se da el nombre, como una de las colaboradoras. Una serie de fotografías que acompañan el artículo muestran a tres mujeres, denominadas como redactoras de La Voz: Teresa Marchisio, María Calvia y Virginia Bolten. ${ }^{8}$ Desafortunadamente, no se arroja más luz sobre estas mujeres, y nos quedamos con la posibilidad intrigante de que La Voz de la Mujer haya sido reeditada luego de su cierre en 1897 y fuera nuevamente publicada durante 1901. Es imposible decir si era éste el mismo periódico y si tenía los mismos redactores.

También se informa que otra versión del periódico, con el mismo nombre, fue publicada en la ciudad de Rosario por Virginia Bolten. ${ }^{9} \mathrm{Se}$ decía de ella que era una "gran oradora" y una organizadora infatigable, y es la única mujer de la que se sabe que fue deportada en 1902 bajo la Ley de Residencia, la cual le dio al gobierno el poder de expulsar inmigrantes activos en organizaciones políticas. También parece que aún otra versión de La Voz de la Mujer se publicó en Montevideo (Diego Abad de Santillán, comunicación personal), y como éste es el sitio en el cual se exilió Virginia Bolten, es razonable suponer que ella puede haber estado involucrada en la organización de la versión uruguaya.

${ }^{8}$ Según Caras y Caretas, María Calvia también fundó un grupo llamado "Los Proletarios".

${ }^{9}$ Quesada (1979) reporta que una de las redactoras apareció en Rosario entre 1900 y 1903. Escribe que los visitantes a la Casa del Pueblo, recientemente construida, incluían a Pietro Gori, “y muchos otros solían reunirse allí: la mujer Marchisio, quien junto a Virginia Bolten fundó La Voz de la Mujer, publicación llamada 'la Michel rosarina' debido al ardor de su oratoria”. (Según otras fuentes, parece más probable que fuera Bolten, y no La Voz de la Mujer, quien fue apodada "la Michel Rosarina".) 
Al igual que muchos otros periódicos anarquistas de este período, $\mathrm{La}$ Voz apareció esporádicamente, llevando en su portada las palabras Sale cuando puede; al principio esto era aproximadamente una vez cada tres semanas, y luego el lapso entre número y número se alargó a un período de entre seis semanas y dos meses. Se publicó en formato de periódico y tenía cuatro páginas. De los números uno al cuatro se publicaron 1.000 ejemplares, de los números cinco, siete y ocho, 2.000, y del número 9, $1.500 .^{10}$ Tal como era normal para estos periódicos anarquistas, era financiado por suscripción voluntaria, con una lista de suscriptores impresa en la contratapa de cada número. Un indicio del temperamento de los lectores lo obtenemos de los siguientes nombres de contribuyentes: "Grupo las vengadoras", "Uno que desea cargar un cañón con cabezas de burgueses", "Viva la dinamita", "Viva el amor libre", "Una feminista", "Una serpiente para devorar burgueses", "Sobrante de Cerveza", "Un hombre que ama a las mujeres".

Los contenidos del periódico eran presentados de diferentes formas; la principal era el artículo, que variaba en longitud de una o dos columnas hasta una página y media. Cada número generalmente contenía un editorial, un poema ${ }^{11}$ y una fábula moral acerca de "mártires" de la sociedad burguesa (los pobres, los trabajadores, las prostitutas) o sus adversarios (los jueces, los curas, la policía). Además, se reproducían traducciones y artículos del movimiento europeo, como lo hacía en todos lados la prensa anarquista de la época. Ellos incluían los escritos de "Soledad Gustavo", Laurentine Sauvrey, Teresa Claramunt, A. María Mozzoni y María Martínez. Las redactoras de La Voz de la Mujer buscaron activamente la colaboración de mujeres anarquistas prominentes y, de acuerdo con una nota en el número 5, le escribieron a Emma Goldman y a Louise Michel en particular. La contratapa del periódico contenía una sección llamada "Mesa Redonda", en la cual se discutían pequeños ítems relativos a noticias de Europa y la Argentina. También aquí aparecían las increpaciones al Partido Socialista de la Argentina por sus políticas reformistas -en relación con el movimiento de la clase trabajadora, no con la cuestión de la mujer-y se reportaban temas centrales relativos a las mujeres. Podía leerse, por ejemplo, acerca de la animosa intervención de una

${ }^{10}$ El número 6 no ha podido ser hallado. Los primeros cuatro números medían $26 \mathrm{~cm}$ x $36 \mathrm{~cm}$, mientras que los restantes eran un poco más grandes y de tamaño variado, lo que sugiere el uso de diferentes imprentas.

${ }^{11}$ Algunos de los poemas eran escritos para ser leídos en los mitines. El número 8 de La Voz incluye un poema de 207 líneas de "Pepita Gherra" destinado, según las redactoras, a ser leído en las reuniones de la Unión Obrera Española. 
joven mujer anarquista en un mitin obrero a favor de la emancipación de la mujer.

La mayoría de los artículos firmados llevaban nombres de mujeres, y la mayoría estaban escritos en español, con algunos ítems ocasionales en italiano. Aunque el periódico aceptaba artículos en cualquiera de las dos lenguas, los nombres de las redactoras, colaboradores y contribuyentes indicaban la afinidad del periódico con el anarquismo español y con la comunidad inmigrante de España. ${ }^{12}$ Esto no es sorprendente, ya que fue primeramente desde España desde donde el feminismo anarquista llegó a la Argentina. Incluso el material feminista de la prensa italiana era escrito, en gran medida, por autoras españolas.

La Voz de la Mujer se describía a sí mismo como "dedicado al avance del anarquismo comunista". Dado que su política correspondía a la variedad de anarquismo militante que defendía los actos de violencia, era publicado de modo semiclandestino. Se dirigía a un grupo de lectores de la clase trabajadora, y sus redactoras escribían frecuente y apasionadamente acerca de la miseria y la pobreza sufrida por las mujeres de esa clase, a la cual supuestamente pertenecían. El espíritu del periódico era de un ardiente optimismo, tal como lo ejemplifica el siguiente verso, perteneciente a un poema titulado "Brindis", por Josefa M. R. Martínez:

\author{
¡Salud, Compañeras! La Anarquía \\ Ya trémola el pendón libertador; \\ ¡Hurra, hermanos queridos, a la lucha! \\ ¡Fuerte el brazo, sereno el corazón!
}

$\mathrm{Al}$ igual que el resto del movimiento anarquista, las redactoras se oponían, de un modo militante, a la autoridad de la religión y del Estado, y eran intransigentemente hostiles hacia la policía y otros representantes del derecho. Tendían a ofrecer rudos consejos a los huelguistas acerca de cómo manejar el acoso policial, urgiéndolos a "matar algunos", para enseñarle una lección a la policía.

El tema central de La Voz de la Mujer, sin embargo, es el de la naturaleza múltiple de la opresión de las mujeres. La tormenta en el movimiento anarquista que respondió a la aparición del periódico parece haber sido causada por el feminismo militante del primer editorial, que tomó la posición distintiva y -para anarquistas y socialistas- herética de que las mujeres constituían la parte más explotada de la sociedad. Un editorial

\footnotetext{
${ }^{12}$ Véase Junco (1976) para una discusión de la familia, el amor libre y el feminismo en el anarquismo español.
} 
posterior afirmaba: "creemos que en la sociedad actual nadie ni nada tiene una situación más miserable que las mujeres desafortunadas". Las mujeres, ellas decían, estaban doblemente oprimidas: por la sociedad burguesa, y por los hombres.

El desarrollo específicamente feminista de la teoría anarquista descansaba en su ataque al matrimonio y al poder masculino sobre las mujeres. El comunismo anarquista había tomado de Engels la crítica al casamiento burgués como un medio de salvaguardar la transmisión capitalista de la propiedad. También reiteraba su visión de que la familia era el lugar de la subordinación de la mujer. Las escritoras de La Voz de la Mujer, al igual que las feministas anarquistas de otras latitudes, prosiguieron el desarrollo de un concepto de opresión que se centraba en la opresión de género. El casamiento no era tan sólo una institución burguesa; también restringía la libertad de las mujeres, incluyendo su libertad sexual. La Voz de la Mujer atacaba el "onanismo conyugal" del matrimonio como una causa central, junto con la opresión de clase, la miseria y la desesperación. Los matrimonios se constituían sin amor, la fidelidad se mantenía por medio del miedo más que del deseo y por la opresión de las mujeres a manos de hombres que odiaban; todo esto era visto como sintomático de la coerción implicada en el contrato de matrimonio. La gente no era libre de hacer lo que le placiera, y menos aún porque hasta 1897 el divorcio era ilegal en la Argentina. Las feministas anarquistas deploraban y buscaban remediar esta alienación de la voluntad individual, inicialmente a través del amor libre y luego, y más profundamente, a través de la revolución social.

La Voz de la Mujer fue un entusiasta partidario del amor libre. Este tema había sido tratado tanto por los movimientos anarquistas norteamericanos como por los españoles, alrededor de la década de 1890, y continuó siendo un ideal anarquista de las décadas posteriores. La defensa del amor libre y la hostilidad al matrimonio fueron compartidas por otros grupos anarquistas y libertarios en Latinoamérica, algunos de los cuales llegaron más lejos que $\mathrm{La}$ Voz, tanto en la elaboración de ideas como en su práctica. En el movimiento, en la Argentina circulaba literatura acerca de los beneficios de las relaciones múltiples, además de información y propaganda acerca de las comunas de amor libre que habían empezado a existir entre las comunidades inmigrantes de algunos países latinoamericanos..$^{13} \mathrm{La}$ Voz de la Mujer ofreció a sus lectoras pocas guías prácticas

${ }^{13}$ La Colonia de Santa Cecilia, en el Brasil, es el ejemplo mejor conocido. El Oprimido estuvo en el centro de un debate acerca de esta cuestión, y aparentemente la publicación habría patrocinado el panfleto Un episodio de amor en la Colonia Socialista "Cecilia", que 
para vivir de acuerdo a su ideal, y no está claro cuáles eran los arreglos sociales previstos para quienes practicaban el amor libre o para su probable descendencia.

Las redactoras parecen haber pensado en una variante liberal de una monogamia heterosexual secuencial, teniendo como ideal a "dos camaradas libremente unidos". En un contexto en el cual la contracepción era, como mínimo, muy difícil de obtener, las redactoras tenían poco que decir acerca de los niños, y lo que sí decían representaba una variedad de puntos de vista. Hay una sola referencia al control de la natalidad, que la escritora aprobaba con el fundamento de que demasiados niños incrementan la pobreza de los pobres (una posición que iba a ganar terreno en España a fin de siglo). No hay discusión explícita en torno al aborto, y las pocas referencias al mismo revelan la ambivalencia de las redactoras. El aborto es mencionado como algo que las monjas y las mujeres burguesas llevan a cabo, y como evidencia de su hipocresía. No hay certezas de si es el acto mismo el que debe ser deplorado, o solamente la gente que lo realiza. Las actitudes hacia los niños van de un sentimentalismo cursi a una denuncia furiosa del rol de la madre. Las redactoras adoptaron la posición convencional anarquista acerca de su ilegitimidad, rechazándolo como un prejuicio social irracional y expresando simpatía por sus víctimas. En general, y especialmente en los números posteriores de La Voz, se escribía acerca de los niños con gran compasión por sus sufrimientos, y se enfatizaba considerablemente el lazo emocional entre la madre y el niño. En un artículo sobre los horrores de la guerra, el foco era el temor de la madre de perder a su hijo en el combate. Las madres eran sostenidas como la principal provisión de afectividad parental. La hostilidad de las redactoras a la familia y el matrimonio, entonces, era atemperada por un respeto por, al menos, algunas convenciones. El hecho de que en ningún punto propusieran las formas más obvias de alivio del problema del cuidado infantil, a través de guarderías o de organización colectiva, es significativo. El cuidado infantil debe haber representado un problema para las lectoras trabajadoras, y la ausencia de toda discusión del asunto sugiere que las actitudes tradicionales hacia la maternidad pueden haber sido más fuertes que lo que hubieran querido las redactoras más radicales.

Se guarda un total silencio, también, acerca de la cuestión del trabajo doméstico. Aunque las redactoras atacaban la opresión de las mujeres y

preconizaba las relaciones múltiples, la abolición de la familia y el cuidado comunal de los niños. Ruvira (1971) dice que estas anarquistas argentinas sí tenían sus uniones libres, y que sus hijos aparecían en el registro civil bajo nombres tales como Anarquía, Acracia e, incluso, Libre Productor. 
su reclusión en el hogar y las labores, nunca propusieron que los hombres compartieran este trabajo en el hogar, ni que el mismo fuera repartido de modo más equitativo. Es muy posible que evitaran, debido a su variante particular de la ideología anarquista, el proponer alguna solución que pudiera haber implicado al Estado o al capital privado (con las guarderías, por ejemplo) o que pudiera haber sido considerada como una medida puramente reformista. Sin embargo, el hecho de que no argumentaran a favor de una distribución equitativa del trabajo en relación con las responsabilidades en el hogar o la comunidad indica que no pudieron romper con nociones imperantes acerca del lugar de las mujeres dentro de la división del trabajo tradicional.

La posición de La Voz acerca del amor libre, aunque era más cauta que la de algunos de sus contemporáneos, equivalía a un rechazo de la autoridad tradicional del hombre sobre la mujer y del control de su sexualidad. En el contexto del machismo del sur europeo, en el cual la virginidad, la fidelidad y la disparidad de criterios para el hombre y la mujer eran la moneda corriente del privilegio viril, tales demandas de autonomía femenina estaban destinadas a provocar una respuesta hostil. Un ítem en el número siete de La Voz de la Mujer muestra que el ideal de las redactoras de una unión y disolución libres, con las mujeres tomando la iniciativa, estaba lejos de ser aceptable para los hombres, incluso dentro del mismo movimiento anarquista. El artículo condenaba la acción del activista anarquista F. Denanbride, quien había disparado cinco veces a su amante cuando ella intentaba dejarlo. (La mujer, una colaboradora de La Voz de la Mujer llamada Anita Lagouardette, había sobrevivido milagrosamente.) El tratamiento de este episodio por parte del periódico ilustra un quiebre en su razonamiento anarquista feminista. Las redactoras veían al amor libre como la solución al problema de las relaciones entre sexos; cuando el matrimonio, la causa de la miseria y la desesperación, desapareciera, la casa se volvería "un paraíso de delicias". Los hombres y las mujeres serían libres de entrar en relaciones con quien ellos eligieran, y de disolverlas a voluntad, sin los efectos corrosivos del derecho, el Estado, y la costumbre. Esta visión ignoraba tanto la subordinación compleja e internalizada de las mujeres, como los modos de opresión y el sentido de superioridad internalizados por los hombres.

La unión libre sólo podría haber sido una solución adecuada si los intereses de ambas partes implicadas hubieran sido idénticos, o si la parte cuyos deseos fueran contradichos no tuviera sentimientos. En cualquier situación en la que los miembros de la pareja en conflicto difirieran en fuerza, obviamente el más débil perdería, y en un mundo en el cual la gente era socializada bajo el criterio de la desigualdad varones-mujeres, 
el más fuerte, el hombre, podría usar las consignas de la "libertad" para imponer su voluntad sobre su compañera femenina -ya sea dejándola cuando ella no quería ser abandonada, o forzándola a permanecer-. Más aún, en un mundo en el cual las mujeres tenían pocas alternativas a la dependencia de los hombres a través del matrimonio, la invitación a la independencia probablemente parecía no sólo romántica sino también una posibilidad más realista para los hombres; por ello, amenazaba, en vez de liberar, a las mujeres menos favorecidas.

A pesar de todo su radicalismo, la consigna a favor del amor libre estaba aún suavizada por las convenciones de la época, y esto era especialmente verdadero en cuanto a sus implicaciones para las prácticas sexuales. La demanda de amor libre tenía que ver con la autonomía personal. Aunque implicaba una medida mayor de libertad sexual, no significaba un libertinaje sexual. La precaución que caracterizaba a la defensa del amor libre de las redactoras puede ser al menos parcialmente explicada por la ambivalencia que ellas expresaban acerca de la sexualidad. Sus escritos sobre este tema, como otros producidos en la España de la época, revelan una combinación de vulgaridad, radicalismo y un pudor conmovido. Se atacaba al matrimonio porque corrompía a las partes implicadas y llevaba a prácticas sexuales degeneradas. En un pasaje particularmente florido, se lo denunciaba como llevando al "fraude y las aberraciones en el coito", con sus correspondientes "asquerosas enfermedades, de ahí las mil y mil asquerosas y repugnantes prácticas que convierten el tálamo nupcial en pilón de asquerosas obscenidades [y de allí] ¡El adulterio!” (No. 1, p. 3). El sexo "degenerado", incluyendo la masturbación, se asociaba con el enemigo, especialmente los curas y los burgueses, quienes eran vituperados por homosexuales y pederastas. Los límites del radicalismo sexual de las redactoras están claros; ellas no defendían la permisividad sexual y no estaban siquiera seguras de que el sexo les gustara demasiado. Sus consignas relativas al amor libre expresaban un deseo de liberarse de ciertos constreñimientos legales y personales, pero la sexualidad debía confinarse al terreno de la práctica normativa.

Esto refleja el contexto cultural del cual emergieron estas mujeres. Ellas percibieron el principal problema en términos de su propia liberación del poder de los hombres y cuestionaron los privilegios de los que los hombres gozaban a expensas de las mujeres. Más aún, dado el clima moral existente y las relaciones de poder entre hombres y mujeres, estas últimas fueron frecuentemente víctimas de una explotación sexual cuyos costos ellas mismas pagaban, en términos de reputación dañada y niños ilegítimos. Por lo tanto, no es sorprendente que la explotación sexual sea un tema recurrente del feminismo anarquista: el sexo era una amenaza para las mujeres. 
La Voz de la Mujer combina varios elementos anarquistas, tales como el odio a la Iglesia y a la explotación de clases, con una crítica específicamente feminista de la explotación sexual de las mujeres. Una enérgica ilustración de esto, escrita en un lenguaje totalmente explícito, está presente en el número 3, en el cual la Iglesia es atacada con todo el veneno del anarquismo español por la hipocresía de sus funcionarios en relación con la sexualidad. "Luisa Violeta" ofrece una narración supuestamente autobiográfica de un incidente entre un cura y ella misma en un confesionario. El cura le reprocha el no asistir a misa. Ella explica que su madre ha estado enferma y que ella ha debido cuidarla, pero el cura no acepta estas justificaciones. "Pero desgraciada, ¿no sabéis que primero es el alma y después el cuerpo?" En el curso de la confesión Luisa pide perdón por masturbarse, un tema que provoca un agudo interés en el otro lado de la grilla. El cura quiere saber exactamente qué partes de su cuerpo ella toca, y si realiza estos actos sola; luego le pregunta si ha sido otra persona quien le ha enseñado a hacerlo. Ella responde que ha sido el cura mismo. En este punto, él la invita a pasar al cubículo e intenta violarla.

La insistencia en la depravación de los clérigos era un tema recurrente, junto con un ataque más general a la inutilidad de buscar en la religión una salvación que sólo podría llegar por medio de la revolución social. Dado que la visión imperante de las mujeres estaba condicionada por expectativas acerca de su religiosidad, piedad y castidad, este tipo de crítica debe haber sido particularmente escandaloso en su momento.

La hostilidad a la Iglesia eclipsaba incluso la simpatía fraternal que las redactoras de La Voz de la Mujer podrían haber sentido por sus hermanas enclaustradas, las monjas. Originalmente, estas mujeres eran tanto las víctimas de la falta de oportunidades como lo eran las prostitutas, con las cuales, en un artículo, eran comparadas. En el número 4, las monjas eran criticadas ácidamente no tanto por su rol ideológico como agentes de los valores religiosos, como por su hipocresía y engaños respecto de la sexualidad ("parásitos de la sociedad, que tras satisfacer vuestros apetitos carnales con vuestros santos varones -los curas- arrojáis los frutos de vuestras entrañas en las calles o los enterráis en los jardines de vuestros conventos", La Voz de la Mujer, No. 4). No es sorprendente que este artículo haya provocado la crítica de lectores de La Voz de la Mujer, lo que llevó a una respuesta en el número 5. La autora insistió con que la historia era verdadera, y citó, en su defensa, noticias de los periódicos en las cuales se informaba de una niña que había sido violada por un cura, y del abandono de bebés no buscados por parte de las monjas.

La hipocresía, los criterios ambiguos, y la explotación social de las mujeres formaban la base de la simpatía feminista de las redactoras 
por las prostitutas. Las prostitutas eran "mujeres caídas", inocentes que habían sido corrompidas, doblemente traicionadas en base a su sexo y a su clase. Un artículo firmado por "Pepita Gherra" en el número 4 contiene esta descripción de la prostituta ideal-típica: “¡Sí, ya lo sé, pobre niña, lo sé, el padre fue amo del tuyo y el hermano fue quien te compró por cuatro monedas! sí, tu padre fue despedido, tu madre enferma y tus hermanitos agonizaban de hambre; sí, ya lo sé, no digas más..." En continuidad con la tradición romántica del siglo xIx, la prostituta era considerada como "el mártir de la sociedad": ella ocupaba un lugar central en la concepción anarquista de la sociedad como el producto de la corrupción social. Las redactoras sostenían que la prostitución era forzada en las mujeres a través de la pobreza, la avaricia masculina y la falta de alternativas realistas para ganar el sustento, y era además reforzada por los criterios ambiguos de la institución del matrimonio, la cual atrapaba a la gente en relaciones vacías e insustanciales y empujaba a los hombres a buscar el placer en otro lado.

A fines del siglo xix Buenos Aires ya estaba en vías de convertirse en la subcapital de Latinoamérica. Aunque en el censo de 1895 había menos de 700 prostitutas registradas, este número era menor a la realidad, si es que debe creerse en otras fuentes. Parecería, según las cifras, que un gran porcentaje de las prostitutas argentinas eran inmigrantes, y esto es consistente con informes provenientes de un tratante de blancas de ese momento (Rock, 1975). El número 8 de La Voz de la Mujer incluye una larga discusión de un panfleto, aparentemente escrito por mujeres que habían sido enviadas a Buenos Aires por un "empresario muy bien conocido" en este rubro, solicitando la intervención de la policía para impedir el tráfico de mujeres. La Voz de la Mujer apoyaba a las mujeres en su movilización contra la práctica, pero consideraba fútil e incorrecto pedir la intervención de la policía.

Los cambios en el grupo de redactoras en los números 5 y 7 están asociados a un cambio de énfasis político -un retiro gradual del feminismo militante de los primeros números en favor de preocupaciones anarquistas más ortodoxas-. Cuando, en sus primeros números, La Voz defendía vigorosamente una posición feminista contra las críticas de los hombres del movimiento, tenía el cuidado de señalar que no estaba contra los hombres sino contra aquellos que se oponían a la idea de la emancipación de las mujeres. A partir del número 3 ya no hay más alusiones explícitas a hombres recalcitrantes, y esto puede tener alguna relación con el significativo cambio editorial que tuvo lugar con el número 5. Este número apareció en un formato diferente, más grande, lo cual era aparentemente parte de una campaña para incrementar el número de lectores. 
Esto era necesario porque había aún "un gran prejuicio contra las mujeres y contra el gran progreso hecho por la propaganda de las mujeres". Se les daba un rol prominente a los artículos de "Pepita Gherra", y cada vez más artículos tendían a ser de temas anarquistas generales más que de cuestiones específicas de las mujeres. El tono era menos militantemente feminista, menos analítico y menos crítico de los hombres que antes. Otro índice significativo del carácter cada vez más defensivo de la publicación era su refutación de que el periódico estuviera en manos del "Grupito Amor Libre"; y es interesante que, a partir de este número, no hubo más discusiones acerca del amor libre. Sin embargo, en las convocatorias programáticas con que terminaban los editoriales, la consigna "Viva el Amor Libre" continuó siendo incluida, junto a "Revolución Social" y "Viva Anarquía".

A pesar del cambio en las redactoras, no hubo ninguna crítica explícita de la línea editorial previa del periódico, y las nuevas redactoras afirmaron su intención de proseguir "la huella de la antigua Redacción, es decir lucharemos sin descanso contra la actual sociedad burguesa; combatiremos sin tregua todos los prejuicios y preocupaciones que en la niñez nos inculcaron hombres estúpidos, mujeres fanáticas y otros miserables que ponen su pluma a disposición de la canalla”. Con el séptimo número parece haber habido otro cambio editorial. De acuerdo con un pequeño anuncio en la última página, un nuevo grupo se encargaba del periódico; como en el caso anterior, no se daban razones para el cambio ni había críticas a la política previa. El único indicio de un cambio de línea consiste en el contenido mismo del periódico; ahora era escrito, aparentemente, casi en su totalidad por "Pepita Gherra", y los tres últimos números estaban todavía menos comprometidos con los temas feministas que los dos previos. Ellos se caracterizan por una preocupación por los temas anarquistas generales, tales como el antipatriotismo y el anticlericalismo.

La aparición de un pedido de ayuda en el número 9 indica que el periódico había entrado en crisis. La tirada del ejemplar cayó de 2.000 a 1.500 en este número, el cual estaba dominado por una disquisición acerca de la guerra cubano-española, pretendidamente publicado en La Voz de la Mujer a falta de fondos para publicarlo como panfleto. La solicitud de apoyo que revisaba el desarrollo del periódico era la siguiente:

\footnotetext{
A los lectores

Un año ha transcurrido desde que salió a luz el primer número de $L a$ Voz de la Mujer.

Un año de luchas, de sacrificios, de crueles alternativas, de esperanzas y de caídas, solamente atenuadas en algo, por satisfacción de la lucha.
} 
Dos Redacciones han estado a cargo de esta hoja, poniendo las dos, su corta inteligencia y sus energías todas al servicio de la causa que defienden: La Anarquía.

En este año la vida de esta hoja ha sido precaria y raquítica, tanto así, que con pesar confesamos que si los compañeros no tratan (si les agrada nuestra propaganda)(1) de ayudarnos un poco más eficazmente, nuestros esfuerzos serán inútiles y tendremos que cesar de publicar La Voz de la Mujer(2) y con ella la del Único periódico de América y tal vez del mundo entero que hace propaganda de nuestros ideales por mujeres y especialmente para ellas.

Lo repetimos compañeros y compañeras, entusiasmo y voluntad no nos faltan, pero nuestras fuerzas son pocas, por eso, si no podemos más, nos retiraremos hasta poder volver de nuevo a la brecha, y así siempre hasta que la hora del combate suene en el reloj de la conciencia humana, para correr a vencer o a morir por la Anarquía, porque por ella dará su inteligencia, su brazo, y su postrer suspiro.

La Redacción de La Voz de la Mujer

(1) A este respecto decimos: que dado el estado de ignorancia en que están sumidas las mujeres, nosotras entendemos que nuestra misión periodística es labrar la inteligencia, otro periódico o este mismo más tarde sembrará y cultivará el grano. Por esto nuestra propaganda es como es, cada periódico tiene su misión si quiere.

(2) O entregarla a otras compañeras con más aptitud y fuerzas.

A pesar de esta convocatoria, con el número 9 La Voz de la Mujer parece haber dejado de existir.

Las dificultades enfrentadas por semejante periódico eran formidables. Reconocía sin rodeos su fracaso en cuanto a la generación del apoyo suficiente, y había una multiplicidad de razones para esto, tanto prácticas como políticas. Entre las dificultades prácticas pueden listarse todas los problemas de publicar bajo condiciones clandestinas o semiclandestinas. La Voz usaba un conjunto de imprentas diferentes y probablemente dependiera de la colaboración de hombres solidarios, quienes a su vez forzaron a las redactoras a moderar sus concepciones más inaceptables. Hay indicios de que el periódico fue distribuido principalmente por activistas varones, y que esos hombres no eran muy diligentes al asegurarse de que circulara, o de que los fondos recolectados fueran entregados a las redactoras. Esto plantea las razones políticas más complejas del ocaso de La Voz de la Mujer: si eran los hombres quienes lo ponían en circulación, entonces había o bien pocas mujeres atraídas por el anarquismo en la Argentina del siglo xIx, o pocas que simpatizaran con el proyecto de La Voz. 
Hay aquí dos temas distintos pero interrelacionados, relativos a la recepción de las ideas anarquistas y feministas. El anarquismo claramente gozaba de una aceptación bastante extendida entre los trabajadores inmigrantes al final del siglo xix y principios del siglo $\mathrm{xx}$, pero este apoyo fue erosionado gradualmente por los cambios en las comunidades inmigrantes mismas. Era popular inicialmente entre los inmigrantes, especialmente los menos favorecidos, porque su cosmopolitismo sin amarras, su idealismo y su oposición militante a todas las formas de autoridad expresaban las frustraciones de una fuerza rural sudeuropea desplazada, que se enfrentaba a las realidades de la pobreza urbana en una tierra extranjera. Las esperanzas frustradas y la ausencia de empadronamiento político encendieron la militancia de estos inmigrantes, y alimentaron su falta de compromiso con el país que los hospedaba. Aquellos que se quedaron, sea por elección o por circunstancia, tenían que sobrevivir dentro de la sociedad argentina. Alrededor de la mitad de los inmigrantes varones se casaron con mujeres argentinas y establecieron una relación menos débil con su país adoptivo. Al mismo tiempo, los trabajadores argentinos, tanto las mujeres como los varones -además de algunos inmigrantes- estaban en la década de 1890 comprometidos con la lucha por reformas prácticas que mejoraran las condiciones de la clase trabajadora. Algunos de los grupos anarquistas entraron en estas luchas y les dieron un perfil militante. Estos grupos continuaron siendo, al menos hasta las primeras décadas del siglo xx, serios rivales del Partido Socialista, el cual era admitidamente reformista.

Las corrientes revolucionarias del anarquismo, tales como la de La Voz, continuaron aisladas; mientras algunos sectores de la clase trabajadora, tanto nacionales como inmigrantes, demandaban una jornada de ocho horas, salarios más altos y mejores condiciones, muchos anarquistas despreciaban esas luchas y convocaban, por su parte, a la acción directa contra el Estado y sus instituciones. La prensa anarquista de una disposición semejante a la de La Voz de la Mujer estaba particularmente desafectada de las luchas contemporáneas. Los contenidos de los periódicos casi nunca mencionan huelgas o represión, reivindicaciones o acción obreras. En lugar de esto, la principal preocupación fue la de la lucha ideológica.

Probablemente, la actitud militante de La Voz de la Mujer en contra de lo que veía como reformismo lo marginalizó en relación con las mujeres trabajadoras a las que buscaba influir. Su naturaleza semiclandestina hizo dificultosas la organización y las reuniones públicas. El periódico aparecía esporádicamente y circulaba principalmente entre los miembros radicales de las diversas comunidades inmigrantes. Así, la mayor proporción del material impreso en La Voz de la Mujer podría haber sido escrita casi en cualquier 
país de habla hispana en cualquier momento entre 1870 y 1930; irónicamente, la sección del periódico que da los indicios más vívidos de la vida en la Argentina de ese momento es la lista de suscriptores, con sus referencias pasajeras a oficios, condiciones de vida, regiones del país y actividades recreativas. En general, sus lazos con las realidades de las vidas de las mujeres inmigrantes en la Argentina estaban extremadamente atenuados.

Incluso en la década de 1890, las rupturas que se habían desarrollado en el movimiento reflejaban la dirección que estaban tomando los acontecimientos. Las variantes más militantes del comunismo anarquista, tales como La Voz de la Mujer y La Voz de Ravachol (así llamada en honor a un tirabombas), rápidamente perdieron terreno frente a las tendencias que eran más sensibles a la clase trabajadora y que abrazaban sus luchas. El movimiento anarquista estuvo, de ahí en más, caracterizado por un creciente apoyo a las ideas anarcosindicalistas. Esto resultó ser, sin embargo, muy escaso y muy tardío, y el anarquismo, incluso en su forma más sindical, se convirtió en una fuerza ya consumida pocas décadas después. El Partido Socialista, fundado en 1894, comprometido como estaba con la participación electoral y la reforma laboral, había sobrepasado a los anarquistas en la segunda década del siglo xx, y ambos habían sido eclipsados por el populismo liberal del partido Radical.

La Voz de la Mujer ya era, por lo tanto, una tendencia minoritaria dentro del movimiento anarquista como un todo, mientras que el anarquismo sufría el desafío de adaptarse tanto a las necesidades de los inmigrantes que planificaban quedarse en la Argentina como a las de la clase trabajadora indigente. Pero La Voz perdió dos veces la competencia. No sólo su política la marginalizó de la clase trabajadora, sino que tampoco ganó un apoyo suficiente de las mujeres.

En un sentido, La Voz no estaba particularmente preocupada en atraer muchos lectores. El feminismo anarquista buscaba desarrollar grupos pequeños de activistas dedicados, antes que un movimiento de masas. Su política era aceptadamente sectaria y sus simpatías estaban reservadas exclusivamente a las mujeres de clase trabajadora y pobres. Había poca o ninguna cooperación con otros grupos radicales que compartían el interés de La Voz en la clase trabajadora. El Partido Socialista era censurado casi en los mismos términos que la burguesía, y su periódico La Vanguardia fue descrito por una escritora, presumiblemente a causa de su reformismo, como "cochino socialístico-burgués". Aunque las mujeres trabajadoras a las cuales estaban dirigidos sus escritos tenían más de una causa de padecimiento, el compromiso de las redactoras con el anarquismo militante les hizo virtualmente imposible involucrarse en una discusión de los problemas prácticos a los que se enfrentaban. 
Había, por lo tanto, una tendencia a evitar formular estrategias precisas de cambio y acción, incluso cuando podía verse surgir ciertas demandas más prácticas. Aparte de la abolición del matrimonio, las redactoras pedían el fin de las oportunidades desiguales y restringidas para las mujeres, de la discriminación de las mujeres en el trabajo, de la esclavitud doméstica, del acceso desigual a la educación y de las exigencias sexuales sin control de los hombres para con las mujeres. Pero estos temas son meramente señalados, con poca o ninguna discusión de los mismos. Dado el interés explícito en las mujeres trabajadoras, hay sorprendentemente pocas referencias a las condiciones de empleo y de trabajo imperantes en la Argentina de esos días. Por cierto, La Voz se oponía a las huelgas por mejores salarios y condiciones. Su única intervención en nombre de las mujeres trabajadoras consistió en señalarles a las lavanderas la inutilidad de boicotear las casas de lavado, en un intento de rebajar el precio de la admisión; en lugar de esto, se les recomendaba romper la maquinaria. Incluso cuando se destinaba un espacio considerable a un tema, como en el caso del amor libre, las redactoras ofrecían a sus lectoras pocas recomendaciones prácticas para realizar este ideal.

A partir del fin de siglo, emergió una variante diferente del feminismo que sí se hizo cargo de estos problemas: la del Partido Socialista. Mujeres como Cecilia Grierson, Alicia Moreau de Justo y Juana Rouco Buela lanzaron la lucha por la igualdad de derechos, mejores oportunidades educacionales y la reforma del código civil, y al hacerlo redefinieron radicalmente la política, la estrategia y el terreno de la lucha feminista. ${ }^{14} \mathrm{~A}$ diferencia de La Voz y aquellos a los que persuadía, el Partido Socialista argentino, influido por la visión gradualista de Eduard Bernstein, estaba comprometido con un programa de reivindicaciones formuladas principalmente en términos de concesiones que podían ser obtenidas del Estado.

Aunque el programa socialista apuntaba a lograr resultados más tangibles que el del anarquismo, carecía del radicalismo feminista ardiente que tanto había formado parte de la militancia del anarquismo. Más importante aún es que en su tendencia a derivar la opresión de las mujeres primariamente del capitalismo, o a verla como mediada por las prácticas discriminatorias del Estado, los socialistas no desarrollaron, como los anarquistas, una crítica radical de la familia, el machismo y el autoritarismo en general. Tampoco la sexualidad ocupó un lugar importante dentro del discurso feminista socialista. Las consignas a favor del amor libre del anarquismo

${ }^{14}$ En 1900 Cecilia Grierson fundó el Consejo Nacional de la Mujer, y cinco años después se fundó un centro feminista en el cual se reunieron las principales miembros de los grupos a favor del sufragio femenino en la Argentina. 
fueron reemplazadas por nociones más tradicionales acerca de la superioridad moral "natural" de la mujer, con todas sus connotaciones relativas al hogar y a la maternidad virtuosa (Little, 1978). Las intuiciones de las feministas anarquistas debían esperar medio siglo para obtener una sustancia teórica e incluso más para formar la base de una práctica distintiva.

Esta estampa de historia anarquista argentina indica que hubo una mayor diversidad de discurso feminista en Latinoamérica de lo que comúnmente se supone. También subraya la tesis de que los individuos que constituyen un movimiento social entran en él a partir de diferentes posiciones sociales y por lo tanto tienen, también, necesidades específicas, así como, en algunas ocasiones, intereses en conflicto. ${ }^{15}$ Las mujeres y los hombres anarquistas, aunque estaban unidos por una causa común, entraron en la política a partir de posiciones diferentes en las divisiones sexuales y sociales del trabajo, posiciones que modelaron tanto su experiencia como, en el caso de las mujeres, sus reivindicaciones específicas. La tensión entre las necesidades de los hombres y las de las mujeres en un movimiento político con objetivos universales fue claramente experimentada por las redactoras de La Voz de la Mujer, como lo ha sido por sus sucesoras en diferentes épocas y contextos nacionales.

A pesar de todo esto, La Voz no logró universalizar su llamamiento feminista. Aunque hubo quienes lo apoyaron entre las mujeres de los centros urbanos de la Argentina, no pudo sostener un grupo de lectores de alguna importancia. Esto no fue, sin embargo, porque sus blancos fueran errados o porque hubiera "importado" una visión ajena e inapropiada de Europa. Las mujeres sufrían tanto en la Argentina como en España o en Italia a causa de la explotación sexual, la aplicación desigual de criterios y las situaciones familiares opresivas, que expresaban tanto la desigualdad como las relaciones de poder entre los sexos. El problema residía más bien en que su mensaje fue expresado en términos demasiado coléricos para la población promedio. La Argentina era una sociedad más secular que muchas otras en ese momento, pero la mayoría de las mujeres, fueran nativas o inmigrantes, se habrían escandalizado por los ataques a la Iglesia y la familia y por la discusión explícita de la sexualidad. ${ }^{16}$ Para muchas mujeres, la familia era un lugar de opresión, pero

${ }^{15}$ Para una discusión teórica de este problema de los "intereses" y el feminismo, véase Molyneux (1985).

${ }^{16}$ Dos escritores ingleses de ese período, pertenecientes a la confesión de la Iglesia Anglicana, lamentan que en 1891 el 37\% de todos los matrimonios en Buenos Aires fueran ceremonias civiles, a partir de la legalización del matrimonio secular en 1887 (Mulhall y Mulhall, 1892). 
también de seguridad relativa en un mundo que cambiaba rápidamente y en el cual tenían pocas alternativas. La abolición del matrimonio sin otros cambios radicales en su posición habría dejado a las mujeres aún más expuestas, amenazándolas no con una libertad mayor sino con una posible pérdida de ayuda financiera a los ojos de la comunidad. La Voz, aunque representó una intervención entusiasta en un terreno importante, tuvo una convocatoria limitada, primariamente por carecer de un interés más profundo en las necesidades y creencias de las mujeres a las que buscó influir.

\section{Referencias bibliográficas}

Abad de Santillán, Diego (1930), El movimiento anarquista en la Argentina, Buenos Aires, Argonauta.

Bourdé, Guy (1974), Urbanisation et immigration en Amérique Latine, París, Aubier.

Ferns, H. S. (1960), Britain and Argentina in the Nineteenth Century, Oxford, Oxford University Press.

Franco, Jean (1967), The Modern Culture of Latin America: Society and the Artist, Londres, Pall Mall Press.

Franco, Jean (1973), Spanish American Literature Since Independence, Londres, Ernest Benn.

Hahner, J. (1978), "The nineteenth-century feminist press and women's rights in Brazil", pp. 254-285, en A Lavrin (comp.), Latin American Women, Westport, Greenwood Press.

Junco, Álvarez (1976), Ideología política del anarquismo español 1868-1910, México, Siglo XXI.

Kaplan, Temma (1971), "Spanish Anarchism and women's liberation”, Journal of Contemporary History 6.

Little, Cynthia Jeffress (1978), "Education, philanthropy, and feminism: components of Argentina womanhood 1860-1926", en A. Lavrin (comp.), Latin American Women, Westport, cт, Greenwood Press, pp. 235-253.

Marotta, Sebastián (1960), El movimiento sindical argentino: su génesis y desarrollo, Buenos Aires, Lacio.

Molyneux, Maxine (1985), "Mobilisation without emancipation? Women's interests, state and revolution in Nicaragua", Feminist Studies, 11, 2.

Mulhall, M. G. y E. T. Mulhall (1892), Handbook of the River Plate, Londres, Kegan Paul, Trench.

Oved, Iaäcov (1978), El anarquismo y el movimiento obrero en Argentina, México, Siglo XXI. 
Quesada, Fernando (1979), Argentine Anarchism and "La Protesta", Nueva York, Gordon Press.

Rock, David (1975), Politics in Argentina 1890-1930, Cambridge, Cambridge University Press.

Rowbotham, Sheila (1974), Women, Resistance, and Revolution, Nueva York, Pantheon.

Ruvira, G. (1971), Orígenes del anarquismo en Buenos Aires 1886-1901, Valencia, Universidad de Valencia.

Segundo Censo de la República Argentina (1898), Buenos Aires, Taller Tipográfico de la Penitenciaría Nacional.

Solberg, Carl (1970), Immigration and Nationalism in Argentina and Chile: 18901914, Austin, University of Texas Press. 

La Voz de la Mujer 
En esta edición se reproducen los contenidos de La Voz de la Mujer, periódico Comunista-Anárquico

(Buenos Aires, enero de 1896-enero de 1897), números 1, 2, 3, 4, 5, 7, 8 y 9. El número 6 no ha podido ser hallado. 


\section{LA VOZ DE LA MUJER}

Aparece cuando puede

y por suscripción voluntaria

Periódico Comunista-Anárquico

Dirección: J. CALVO, a cualquier periódico

Nuestros propósitos

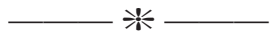

\section{Compañeros y COMPAÑERAS ¡SALUd!}

Y bien: hastiadas ya de tanto y tanto llanto y miseria, hastiadas del eterno y desconsolador cuadro que nos ofrecen nuestros desgraciados hijos, los tiernos pedazos de nuestro corazón, hastiadas de pedir y suplicar, de ser el juguete, el objeto de los placeres de nuestros infames explotadores o de viles esposos, hemos decidido levantar nuestra voz en el concierto social y exigir, exigir decimos, nuestra parte de placeres en el banquete de la vida.

Largas veladas de trabajo y padecimientos, negros y horrorosos días sin pan han pesado sobre nosotras, y ha sido necesario que sintiésemos el grito seco y desgarrante de nuestros hambrientos hijos, para que hastiadas ya de tanta miseria y padecimiento, nos decidiésemos a dejar oír nuestra voz, no ya en forma de lamento ni suplicante querella, sino en vibrante y enérgica demanda. Todo es de todos.

Hasta ayer hemos suplicado a un Dios, a una virgen u otro santo no menos imaginario el uno que el otro, y cuando llenas de confianza hemos acudido a pedir un mendrugo para nuestros hijos, ¿sabéis lo que hemos hallado? La mirada lasciva y lujuriosa del que anhelando cambiar de continuo el objeto de sus impuros placeres, nos ofrecía con insinuante y artera voz un cambio, un negocio, un billete de banco con que tapar la desnudez de nuestro cuerpo, sin más obligación que la de prestarles el mismo.

Marchamos más adelante, siempre confiadas y con la esperanza puesta en Dios y en los cielos, y después de haber tropezado y caído por no mirar por donde caminábamos mientras fijábamos nuestra anhelante mirada en los cielos, ¿sabéis lo que encontramos? Lascivia y brutal impureza, corrupción y cieno y una nueva ocasión de vender nuestros flacos y macilentos cuerpos. Volvimos atrás nuestros ojos, ¡secos sí, muy secos ya! y allá, a lo lejos, en lontananza, casi vimos a nuestros hijos, pálidos, débiles y enfermizos... y la brisa caliginosa ya, nos traía la eterna melodía del pan. ¡Mamá, pan por Dios! Y entonces comprendimos porqué se cae... porqué se mata y porqué se roba (léase expropia).

Y fue entonces también, que desconocimos a ese Dios y comprendimos cuán falsa es su existencia; en suma, que no existe.

Fue entonces que compadecimos a nuestras caídas y desgraciadas compañeras. Entonces quisimos romper con todas las preocupaciones y absurdas trabas, con esta cadena impía cuyos eslabones son más gruesos que nuestros cuerpos. Comprendimos que teníamos un enemigo poderoso en la sociedad actual y fue entonces también que mirando a nuestro alrededor, 
vimos muchos de nuestros compañeros luchando contra la tal sociedad; y como comprendimos que ése era también nuestro enemigo, decidimos ir con ellos en contra del común enemigo, mas como no queríamos depender de nadie, alzamos nosotras también un girón del rojo estandarte; salimos a la lucha... sin Dios y sin jefe.

He aquí, queridas compañeras, el porqué de nuestro periódico, no nuestro sino de todos, y he aquí, también, porqué nos declaramos comUnistas ANÁRQUICAs proclamando el derecho a la vida, o sea igualdad y libertad.

\section{LA REDACCIÓN}

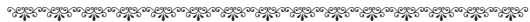

\section{BRIINDIS}

¡Salud Compañeras! La Anarquía

Ya tremola el pendón libertador; ¡Hurra, hermanos queridos, a la lucha! ¡Fuerte el brazo, sereno el corazón!

Miradlo ¡sí! ¿No veis el Horizonte Radiante luz iluminando estar? Y entre inmensos cendales ondeando Nuestro rojo pendón. ¡Hurra a luchar!

Que no haya entre nosotras rezagadas Nuestra lucha es a muerte y sin cuartel; ¡Hurra! hermanas queridas, otro

Y ¿quién duda que habremos de [esfuerzo, [vencer?

Estrechemos las filas, camaradas El rojizo pendón al tremolar, ¡Anarquía y Salud! ¡Y destrozadas Las falanges burguesas huirán!
Serenas, sin temor, siempre avanzando, Siempre altivas marchamos por

Los esbirros burgueses arrollando

[doquier,

Destrozando las leyes y el poder.

¡Compañeros! Cada claro en nuestras

Contestado ha de ser con la [filas [explosión, Y así, cual torrente, iremos formidable Proclamando Social Revolución.

Josefa M. R. Martínez

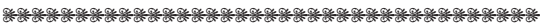

\section{¡OBREROS!}

¿Será posible, que jamás os habéis de dar cuenta de lo que sois y deberíais ser?

¿No habéis comprendido aún, el tristísimo y repugnante papel que representáis cuando acudís, como miserables idiotas, a esas plazas, a esas romerías, a esas paradas militares, etc., en donde sois despreciados, y escarnecidos de mil maneras y modos?

¿No habéis observado, pobres ilusos, el desprecio con que sois mirados, por los que os roban?

¿No habéis visto, cual se apartan de vosotros, donde quiera que os presentéis, aquellos a quienes con vuestro sudor mantenéis y sostenéis de mil modos, y dais vida, como el sol da luz, como el fuego da calor?

Id, sí, pobres gentes, como ellos os llaman, id a divertir al verdugo, id a animar sus fiestas, id a ser el objeto de la risa de nuestros explotadores, id a recoger las denigrantes frases con que os nombran. 
Id a la catedral a contemplar boquiabiertos, la exuberante, la hidrópica vitalidad de los chupadores de sangre obrera; id a contemplar la hipócrita faz de los que nos llaman borregos; id, con ojo avizor y atento oído, a escuchar las mil frases de la refinada hipocresía de un fraile, sea un puerco Castellano o un mastín Jara.

¡Id a ser el hazme reír de esa fiera insaciable, de esa hiena jamás satisfecha, de ese roedor cáncer, de ese ponzoñoso reptil a quien, por decirlo todo, se llama "Burguesía", palabra que quizá no comprendéis, porque en sí encierra todo lo inicuo, todo lo infame, todo lo más asquerosamente repugnante que concebir pueda el pervertido y sanguinario cerebro de un... ¡hombre!

Id, pero al menos, daos cuenta del triste, sí, muy triste papel que allí desempeñáis.

Mirad, ¿veis, allí en aquellas que se llaman Romerías, aquello que tiene tantos escudos y colores? pues aquél es el "palco oficial", ¿sabéis? pues allí no tenéis entrada, allí no permiten que entréis, pues vuestras torpes maneras, vuestras manos callosas (que a ellos sustentan), no pueden, ni deben (dicen), estrechar la fina y enguantada diestra de tanto y tanto... Burgués (puff), de tanta y tanta noble y emperifollada... Burguesita: sabéis, se os desprecia y causáis asco, ¿entendéis? ¡asco!

¿Veis aquello, mirad; aquello que se llama palo jabonado? pues bien, aquel palo está puesto allí para vosotros, para los obreros, ¿sabéis para qué? para ellos poderse reír de nuestra torpe conducta, sí, para vernos forcejear, cuando inten- temos subir a alcanzar el miserable premio que la refinada "caballerosidad"... Burguesa nos ofrece.

¡Ah! ¡tenéis hambre! ¡por la cara de un Burgués!... ¡expropiad, matad todo eso, es bueno y natural, pero jamás debemos renunciar a ser hombres, para ser micos o fantoches!

Mirad a aquel hermano, aquel compañero nuestro, ¿vedlo cual forcejea para subir? ¿oís las carcajadas estallar vibrantes? ¡Ah! es la fiera, es la burguesía que se refocila de alegría cual se refocila el cerdo entre el barro, o el juez ante la veintena de infelices víctimas que piensa enviar al cadalso, sí ella, esa fiera llamada burguesía, se refocila al vernos, tan brutos, tan torpes y piensa: Mientras haya tanto bestia, no temo a nada, ni a nadie.

¿Habéis visto u oído decir, cual se revuelca trémula, delirante de goce, la hiena después de hundir hocico en las entrañas de la víctima, y la contempla inerme y aspira con anhelante delicia los vapores de la sangre en tanto que se revuelca en ella?

¿No habéis oído decir cual se aprieta con las finas manos la exuberante panza, el reyezuelo, presa de convulsiva risa, y babeante el "real" labio, mirar con el rostro descompuesto y amoratado aún por la risa el rostro compungido del infeliz bufón, a quien acaba de aplicar un "real" latigazo?

Pues así, de tal modo, y con tales nobles pesares, se ríen de ese infeliz, es decir de nosotros.

Pero, venid, ¿veis aquella criatura que, pálida y demacrada, la faz débil y enjuto el cuerpecito, está tirada, por decirlo así, entre una rueda de estúpidos? ¿la veis?, mirad, su gorrita puesta 
con refinada "arte" delante de él, ¿veis cómo mueve sus tiernas manitas agitando sin cesar ese ronco y desapacible trasto o acordeón? ¿oís esa música que a muchos hace reír y a otros aplaudir? ¿la oís? pues bien, ¡esa música es la del hambre! Ese gusto os demanda una limosna, y esos delicados y tiernos deditos que veis agitarse y oprimir febriles el teclado debieran manejar un lápiz y ejercitarse en algo más bueno, más adecuado a la edad de la persona que los maneja.

Pero, que, ese que veis niño aún (le hemos visto, tendría seis o siete años) tiene padres quizá y ellos se ven obligados por esta sociedad (repleta de virtuosas damas) a enviarlo a mendigar: ¡es tan cara la subsistencia! ¡Ganan tan poco!

Y mañana, hombre ya, ese que hoy crece como parásita planta, y vive de la pública caridad (maldita sea ella) lejos, muy lejos de las maternales caricias, entregado a sí mismo, después de haber cruzado la primera etapa de la vida como mísero ilota ¿qué hará cuando se vea sin pan, sin hogar, sin amor? ¿qué hará?

Matará, quizás, ¡ah! entonces, sí, entonces la sociedad lanzaráse sobre él como furia, como ircana fiera, y le enviará a un hondo y fétido calabozo, ¡entonces sí, que esta sociedad decrépita y corrompida, tendrá leyes, jueces y verdugos, con que hacerse justicia y castigar! ¿Y quién, pregunto yo, quién castigará a ella por haber robado al padre del niño, y al niño mismo los medios de sustento y de educación? ¿quién tomará en cuenta los actos de la sociedad para juzgar, quién entre ella y el niño es más criminal? ¡Ah, dinamita! ¡cuánta pudridez hay que remover y extirpar!!!

Pero basta. Ven hermano mío, ven compañero, ven, vamos a esa Catedral a cuyas puertas tú y otros van a abrir la boca, vamos y te explicaré lo que en ella pasa.

Lo ves, tú y yo, y con nosotros todos, los obreros tenemos la entrada prohibida, no somos hombres, y es forzoso quedarnos a la puerta como quedan los caballos; ¿y qué? ¿somos acaso para el burgués algo más que un caballo? no, por vida mía, somos sí un objeto de explotación y de servicio, como un par de botas o un paraguas, pero menos, mucho menos apreciable que un caballo o un coche; y si no observad, y veréis cuál cuidan y tapan en invierno a los lujosos troncos, mientras tú y yo, y todos los obreros, vamos semi-desnudos, andrajosos, y ateridos de frío con el semblante demacrado y vacío el estómago, a nuestras embrutecedoras ocupaciones.

¿Lo ves? hoy hay fiesta patria, la plaza llena de infelices hombres, que más que tales parecen espantajos, según están de macilentos y flacos, ¿los ves, con esos disfraces y esos instrumentos, no de trabajo, sino de muerte al hombro? los ves, ¿con ese trapo de color atado a un palo? ¿qué parecen? ¿qué serán? ¿locos tal vez? no, son hombres que la moral y cariñosa piedad burguesa tiene, para que cuando tú pidas pan te den plomo, y para defender el producto del robo hecho, día a día, ja ti a mí y a todos los obreros! ¡Ah! ¡y pensar que esos hombres son nuestros hermanos! que debieran verlo al menos, y que son enemigos a quienes nos veremos obligados a salu- 
dar con la explosión! ¡Maldita seas sociedad que tanto nos obligas, ruede pronto tu maldito régimen y con él las cabezas de tanto y tanto infame verdugo de la humanidad!

Mira hermano mío; ¿ves cual brilla reverberando en mil cambiantes la profusión de las innumerables bujías? ésas se queman a tus expensas y el calor y la claridad que producen, falta en tu hogar, en las tristes y frías noches del invierno y... pero escucha ¿oyes esa señal? anuncia que van a salir los enguantados canallas que para mejor engañarte han estado durante cinco minutos golpeándose el pecho, para que nosotros les imitemos y así cogernos desprevenidos para saciar en nosotros su sed de sangre, en nuestras hijas su lujuria y en nuestros hijos su brutal pasión de pederastas y sodomitas!

Escucha, suena su señal de salida y todas esas momias o soldados, presentan las armas, como indicando que están dispuestos a matarnos, por defenderles ¿los ves? ahí salen, mírales bien, todos esos son parásitos, vampiros, ladrones y zánganos de la social colmena.

¿Oyes? están hablando; escucha "¡Hermano!" ite tratan de hermano!... iy ellos están repletos y tú hambriento!...

..."la gloriosa bandera de la patria..." te hablan de patria y aquel que allí ves aplaudiendo con rabiosa furia, irá dentro de dos horas a exigirte el importe del alquiler de tu pieza, y guay de ti si no tienes con qué pagar; tú, tus hijos, tu compañera y tus trastos irán a parar a la calle en patriótica confusión...

“...Este glorioso día..." Llaman glorioso a este día porque nos contemplan a sus pies humillados, escarnecidos y hambrientos y por ello se regocijan.

¡Vedlos! allí está el obispo con el general, el fraile con el diputado, felicitándose mutuamente de su obra, es decir de nuestra estupidez.

¡Vámonos obreros, vámonos, y jamás volvamos a tales fiestas o escarnios mejor dicho, en las cuales se nos desprecia y humilla hasta tanto de llamarnos sus hermanos; vámonos, pues para ellos somos la "plebe" que viene al espectáculo de las banderas, de las músicas, y de las... porquerías!

¡Vámonos, y que cuando volvamos seamos preparados, con la dinamita en la mano para ponerla en acción, y entonces veremos huir a toda esa cobarde canalla, cual huyen al fulgurar el nuevo día, los espectros, que la pesadilla de un horrible sueño forjó durante la noche !...

La pesadilla es la burguesía. El nuevo día: la Anarquía.

¡iHurra, pues por ella!!

¡Muera la explotación!

¡iiViva el comunismo-anárquico!!! ¡Viva la libre iniciativa!

Josefa M. R. Martínez

\section{LA DONNA}

NELLA SOCIETÁ ATTUALE

La donna nella Societá attuale é la vittima destinata ai capricci, alle passioni, e, delle volte, alla tirannia dell'uomo. Niente di piú ingiusto é la disuguaglianza stabilita artificiosamente tra l'uomo e la donna. Si comincia 
col dargli un'educazione molto limitata; continua poi con la vita domestica, dove la donna é destinata al servizio dell'uomo; dopo nella scalla sociale, la donna é considerata inferiore all'uomo, indegna di qualunque sia cosa; tutto questo per mantenere la donna in uno stato di dipendenza economica e morale verso luomo. L'educazione imperfetta e pessima, la differenza del lavoro, piú ó meno degradante, che gli é destinato, il salario piú misero e la prostituzione che l'aspetta quando non trova chi veglia sulla sua esistenza.

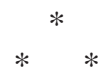

Non esiste una situazione piú tragica che quella di una ragazza povera; le occupazioni che trova sono poche, e molte volte son trame tese per la sua perdizione. Ma questo non é tutto; a curarsi dell'esistenza fisica, viene quella di amare e di essere amata, di trovare a chi confidarsi, di godere le delizie della vita; ma semplice, ingenua, fidata, acetta la mano del primo che la sollecita, consacrandosi interamente la vita alla sua felicitá. Pero non trova altro che inganno, egoismo, calcolo, per abusare della sua minima debolezza; e l'uomo non tiene che ironia e disprezzo. E la donna combattuta per la necessitá di amare e ribassata la sua dignitá, per instinto di conservazione, diventa allora disconfidata, astuta, ipocrita, dissimula e inganna. L'innocenza é sparita, ogni sentimento morale, perduto; discacciata da tutti la Societá gli atribuisce la colpa; non trova alcuno che gli rechi un solievo alle sue pene; cosi lottando in questa misera situazione, non gli resta che prostituirsi.

Quante sono quelle che lottando sino all'ultimo, si sono tolte la vita?

Molte altre, obbligate dall'ambiente attuale, si sono ritirate dalla Societá perché abbandonate dai parenti stessi, che insieme alla Societá, la ritengono colpevoli.

E davanti a questo spettacolo, voialtri borghesi, attribuite la prostituzione, origine del vizio e della corruzione di un certo numero di individui d'ambo i sessi; e affermate che se questi non fossero nati, la prostituzione non esisterebbe.

Vi sono una quantitá di individui che esercitano sulla prostituzione, servendosi di qualunque sia mezzo, per tirare la vittima nell'abisso; essendo questa speculazione divenuta attualmente come tutte le altre.

Di tutte le industrie, questa é la piú abbietta, la piú lucrativa.

Vi sono case appositamente consacrate alla prostituzione, dove la ragazza o la donna vergognosa, lasciano il loro indirizzo per essere pronte alla chiamata di alcun avventore..., un esercito di sensali, di commissionisti, sono impiegati in questa ignominosa industria, portando seco la disperazione e il dolore di tante famiglie, prostituendogli le loro figlie.

É cosí, Signori Borghesi! Non é il vizio o la corruzione l'origine della prostituzione, se non altro il vostro infame regime e le vostre iniquitá. Voi Borghesi siete la causa! Mantenendo la donna nell'ignoranza e nella credenza della sua debolezza, dettando leggi nocive alla donna, facendo credere al popolo incosciente che il sesso 
femminile é inferiore all'uomo, per conseguenza, l'avete educata secondo la vostra volontá e convenienza.

Ah! questa si chiama civilizzazione, o Borghesi? Ah! questo si chiama progresso?

Mentite! questo non si chiama progresso, ma bensí un tempo barbaro e regresso!

Oh, donne del popolo! non vedete in che fango vi ha gettato la Borghesia?

Se avete coscienza di voi stesse, ribellatevi contra questi parassiti della Societá attuale e mostrate all'umanitá che siete forti e non deboli comme i vostri nemici vogliono farlo credere.

Lottate insieme con i desiderati della fortuna, con gli operai conscienti, perché questi sono i veri tuoi amici; perché un giorno non lontano potete emanciparvi di questo giogo che per tanti secoli avete sopportato, dovuta alla vostra ignoranza e alle idee religiose che vi hanno inculcato i dominatori della vostra coscienza la causa della vostra perdizione.

Quando vi sarete ribellate contra questa ipocrita istituzione, allora sarete anarchiche, e comprenderete che l'Anarchia é la vostra salvazione, e lotterete con noi perché sia prossimo il giorno della riscossa e la bandiera dell'avvenire brilli nell'umanitá intera piantata sulla barricata della rivoluzione sociale!...

Solo allora, la vostra schiavitú sará finita, e griderete con tutta la forza delle vostre viscere:

Viva la nostra Emancipazione!

Viva l'Unione libera!

Viva l'Anarchia!

Una Stiratrice

\section{EL AMOR LIBRE}

\section{¿Por qué lo queremos?}

Creen los ignorantes y dicen los mal intencionados que la idea Anárquica está en pugna con todo lo bueno, lo bello, con el arte, las ciencias, y sobre todo, con el hogar.

En efecto, muy repetidas veces hemos tenido ocasión de oír de los labios de algunas obreras lo siguiente: “¡Oh, buena está vuestra idea Anárquica! ¡vosotras queréis que todas las mujeres de esposas, hijas, madres y hermanas, nos convirtamos en mancebas, juguetes viles de las desenfrenadas pasiones del hombre!"

A las que tal dicen y creen nos dirigimos. Veamos.

Nosotras creemos que en la actual sociedad nada ni nadie es más desgraciada en su condición que la infeliz mujer. Apenas llegadas a la pubertad, somos blanco de las miradas lúbricas y cínicamente sensuales del sexo fuerte. Ya sea éste de la clase explotadora o explotada. Más tarde, ya "mujeres", caemos las más de las veces víctimas del engaño en el lodazal de las impurezas, o en el desprecio y escarnio de la sociedad, que no ve en nuestra caída nada, amor, ideal, nada absolutamente, más que la "falta".

$\mathrm{Si}$ realizamos lo que algunas creen su dicha, esto es el matrimonio, entonces nuestra condición es peor, mil veces peor. La falta de trabajo en el "marido", lo escaso de la remuneración, las enfermedades, etc., hacen que lo que en otra circunstancia sería el colmo de la dicha, sea en nuestra 
condición una grave y temible carga, para los "esposos". En efecto nada tan bello, tan poético, tierno, agradable y simpático como un niño, un hijo ¡he ahí el colmo de la felicidad del matrimonio!; pero jay del pobre! ay del hogar en donde se cierne la miseria y en donde hay un pequeño ser que necesite nuestros cuidados, nuestras caricias y atenciones jay de aquel hogar! no tardará en producirse en él mil riñas y disgustos sin cuento. ¿Sabéis por qué? aquel nuevo ser necesita mil cuidados que impiden a la joven madre de ayudar a su compañero a soportar los gastos del hogar, que por otra parte aumentan considerablemente en tanto que las entradas disminuyen, de ahí que lo que debiera ser anhelo y dicha del hogar, sea considerado como una carga, un estorbo y un motivo de disgustos y miserias que con todo cuidado conviene evitar, con el onanismo conyugal, los fraudes y aberraciones en el coito, con todo su séquito de asquerosas enfermedades, de ahí las mil y mil asquerosas y repugnantes prácticas que convierten el tálamo nupcial en pilón de asquerosas obscenidades, de ahí el hastío, el aburrimiento, las enfermedades y la tan decantada "falta" contra el "honor". ¡El adulterio!

Suprimida la causa muere el efecto, suprimida la miseria, desaparecen tales asquerosidades, y el hogar, lejos de ser lo que hoy es, sería un paraíso de goces y delicias.

¡Cuántas confidencias hemos recibido de nuestras amigas, víctimas expiatorias de tales actos! - ¿Y qué? nos respondía el compañero cuando en cara le echábamos tales actos: ¿No saben ustedes cuántos gastos ocasiona un hijo? Partera, médico, medicamentos, dieta, cuidados, y luego la lactancia; ¿cómo haría yo que hoy que trabajamos los dos, apenas nos es dado vivir, cómo haría entonces, cuando los gastos aumentasen y las entradas disminuyesen? ¡Déjenme de chicos, al diablo con ellos!

¿Qué tal? queridas compañeras ¿es esto amor, hogar, cariño? ¡Asco da el pensar que por tal tenga que pasar una mujer; y no obstante es tan cierto!...

Ahora bien, nosotras al proclamar el amor libre, la libre unión de los sexos, creemos firmemente que con ello desaparecen todas estas repugnancias. Unidos libremente y no teniendo nada que temer, pues tendríamos asegurado el sustento para los seres que, fruto de amor, produjera la unión de aquellos que en alas de sus amores fundían dos seres en uno, naturalmente que serían felices y libres los dos; compañeros de sus acciones respectivas, no tendrían que temer nada el uno del otro.

Se nos ha dicho que si el amor, la unión, etc., fueran libres, como deseamos, el hombre cambiaría continuamente de mujer y la mujer de compañero, que no teniendo nada que temer de la sociedad ni de la ley, no serían fieles el uno al otro, mientras que hoy, ya sea porque la ley castiga a la adúltera o adúltero, o bien por temor a la crítica social, los esposos se soportan mutuamente sus faltas y rarezas.

Nada, queridas compañeras, tan incierto como eso. Tanto en uno como en otro sexo lo que se busca, no es la satisfacción de un apetito más o menos carnal, no, lo que se busca es la felicidad, la dicha, tranquila y hones- 
ta, y todo ser, medianamente educado, busca la procreación y la realidad de su ilusión, de su ensueño; si hoy la sociedad es tan material, tan cínicamente egoísta, se debe a que, siendo el capital el agente con el cual se compran u obtienen los goces y necesidades, de ahí que todos pongan más o menos empeño en adquirirlo.

Por otra parte, nosotros, "la escoria" como nos llaman, de la sociedad, viviendo como vivimos desde nuestra temprana edad, sujetas al trabajo que en la forma que hoy se practica, no sólo es degradante y martirizador, sino que es embrutecedor también, naturalmente que no poseemos esa educación que los burgueses en su afán de monopolizarlo todo, monopolizaron también, y por consiguiente no conocemos esos mil goces que a cual más elevado proporciona ésta: tales son la pintura, la música, la poesía, la escultura, etc., etc., y siendo esto así, es indudable que somos en todos los actos de nuestra miserable vida, mucho más materialistas que debiéramos serlo y que seríamos estando educados no como hoy se educa la burguesía, sino mucho mejor aún. El arte eleva el sentimiento, y no poseyendo éste, ni siquiera en su mínima expresión, claro está que no podemos elevarnos hasta él.

No siendo libre la educación y no pudiendo disponer de tiempo suficiente para adquirirla ¿cómo vamos a ser educadas? ¿Quién ignora que desde nuestra más temprana edad el taller nos traga y martiriza? En él no es donde nos podemos educar, muy al contrario, allí hay de todo, de todo, menos eso... iy cien y cien veces hemos visto víctimas de la lubricidad burguesa las míseras obreras, bajar rápidamente en horribles tumbos y caer despeñadas al abismo del vicio, que cada vez más hambriento e insaciable las tragaba, cubriéndolas de cieno y lágrimas, que, niñas casi... que apresuraban por sí mismas su caída, para con ella librarse de la rechifla y el escarnio de sus mismos verdugos!...

En esta sociedad todo eso es natural, dado el grado de ignorancia en que nos encontramos. Coged a un hambriento y ofrecedle un trozo de pan, por negro que éste sea y al mismo tiempo una guzla, una pintura o un poema, aun que ésta sea una inmortal creación de Shakespeare o Lord Byron ¿qué cogería primero? ¡el pan! y no el libro o guzla; claro está, el espíritu necesita, para que éste tenga cómo manifestarse, materia, y primero y más apremiantes son las necesidades de esta última que las del primero.

Indudable es, pues, que en una sociedad cuyos miembros o componentes fuesen educados en grado más o menos perfecto, éstos podrían unirse libremente y sin temor de ser por esto menos felices que con la bendición de un tercero.

La ley, la sociedad, en su afán de gobernarlo todo, nos obliga a que concurramos a rendirle ciego homenaje en tal acto. Nosotras no necesitamos tales bendiciones ni ceremonias, y eso es tal como si tomáramos dos perros que anduvieran a brincos en la calle y les dijéramos al mismo tiempo que los uníamos uno al otro: "sed felices yo os lo permito", tal caso harían como si dijésemos lo contrario.

En buena hora que los burgueses que deben a su muerte legar el producto de sus robos a sus hijos, en bue- 
na hora que ellos vayan a tal o cual parte, pues de no hacer tal, la ley no reconocería a sus hijos herederos. Eso es cuestión de negocio, y eso para ellos está ante todo.

Pero en una sociedad donde no habrá tales "negocios", no es preciso tal pavada. El casamiento, como se dice hoy, o más bien la ceremonia de la bendición, no significa más que la conformidad de la sociedad para tal acto, así, pues, si otra sociedad aceptara como costumbre la libre unión de los sexos claro es que ella quedaba conforme con tal práctica y asunto concluido. Muchas y muchos no dejarían de unirse libremente si no temiesen la crítica de los demás y sólo esto los detiene; dejemos pues hacer y hagamos lo que con nuestro gusto esté y querramos hacer sin perjudicar a nadie.

En cuanto a que el temor al castigo impida la infidelidad conyugal, no creemos que este sofisma valga siquiera el trabajo de combatirlo. Cualquiera reconoce que ésta es una "falta" que puede, de mil veces, novecientas noventa y nueve ponerse en práctica sin que la autoridad, la ley, etc., se den cuenta, además creemos que la persona que por temor al castigo permanezca "fiel" a un compromiso que pudo contraer engañada, o por otra causa obligada a ello, es como si fuese "infiel", aparte de que valdría más que lo fuese, es decir, que se marchase, puesto que si quiere a otro u otra, es claro que será porque no quiere a la persona con quien la sociedad la obliga a compartir el pan y el techo, lo cual si no es prostitución, poco, muy poco dista de ella, pues para hacer tal, es preciso que mienta amor a quien solamente odia, que engañe y que sea hipócrita, que se dé, en fin, a aquel o aquella a quien detesta. Siendo esto así, natural es que no tardarán en producirse en el hogar desavenencias, disgustos y mil otras cosas y casos que amarguen la existencia de ambos compañeros.

Si éstos fuesen libres de sus actos, no se sucediera tal y, por el contrario, si poseyesen el grado de cultura que en nuestra sociedad futura habrá.

Para el próximo número hablaré del divorcio como hoy se practica, advirtiendo a las compañeras y compañeros que siendo este periódico comunista-anárquico, está a disposición de todos, y pide a todos ayuden con lo que puedan y quieran, ya sea intelectual o materialmente, y cuantos más sean los esfuerzos que por él se hagan, más veces se publicará.

Siendo nosotras mujeres, indudablemente no contamos con tanto conocimiento entre los compañeros, como deseáramos; teniendo en cuenta esto, pedimos:

De cada uno según sus fuerzas.

¡Viva la Anarquía! ¡Viva la Revolución Social! ¡Viva la libre iniciativa! ¡Viva el Amor Libre!

Carmen Lareva

\section{$\mathrm{NOTAS}$}

\section{A los colegas}

¡Compañeros salud! Ya lo veis, a pesar de Kier y de sus reputadas macanas, a pesar de todo y de todos los pesares existentes: uno más. 
Dicho esto sólo nos resta deciros que nos recibáis en vuestras filas y:

¡Adelante! ¡Todo por la Anarquía!

\section{Otro}

Por falta de tiempo y de práctica hanse deslizado en este número algunos errores que procuraremos evitar en lo posible a nuestras fuerzas, para los próximos números.

$\mathrm{Si}$ algún compañero encuentra algo que no esté conforme con la idea Comunista-Anárquica, rechace como nosotros lo hacemos desde ya y tómelo tal por error involuntario y falta de práctica.

\section{Lista 6 y 7}

A los compañeros a quienes les hemos dado las listas 6 y 7 para $\mathbf{L a ~ V o z}$ de la Mujer, les pedimos nos envíen lo recolectado a la brevedad posible; o nos avisen para mandarlas buscar.

\section{Permanente}

Compañeros: Para todo lo referente a La Voz de la Mujer dirigirse a nombre de Josefa Calvo, a cualquier periódico Anárquico en curso de publicación en Buenos Aires (R. A.), de los cuales saben nuestra dirección y los que no la sepan preguntan a los compañeros del Perseguido.

$$
\text { * * } *
$$

La Voz de la Mujer dará respuesta de todo trabajo que se le envíe, ya en prosa o verso en Español o Italiano. Siempre que sean útiles para la propaganda del Comunismo-Anárquico, que tal es nuestro ideal, lo publicaremos, de lo contrario diremos la causa.

$$
*^{*} *
$$

Compañero Palazo: Ve si puedes hacer algo por nosotras y nos contestas.

$$
\text { * }
$$

Mar del Plata

Compañero Ceytun: Lo mismo te decimos a ti, procura hacer algo y no olvides la correspondencia que te pedimos.

Fíjate en el déficit y ya sabes...

¡Salud!

\section{Lombroso}

Hemos sabido que Lombroso, el nunca bien ponderado, amalgamado fraseológico y macaneador ha sido condenado por el tribunal de Comercio de Rouen, al pago de 2.500 francos de multa.

La causa es que en una obra que últimamente sacó a la luz titulada la "Grafología" en vez de ser de su cosecha, era la de otro escritor.

Ése es uno de los tantos anatemizadores del anarquismo; ése es el que dice somos todos y todas, según su Macanología, predispuestos al crimen por esto y por lo otro. Seguramente Lombroso debe también ser uno de los tantos por eso de querer comer con lo que otro trabaja...

\section{La Libertad Burguesa}

Leemos en La Prensa del 18 de diciembre:

Suicidio: La familia de D. Roberto Paterson, domiciliada en la casa calle Chacabuco 1437, había criado y tenía a su servicio a la joven de 18 años Laura del Carmen.

La familia notó que en las diversas ocasiones que mandaban a la calle a Laura, ésta se demoraba más de lo necesario en hacer los mandados. 
La familia de Paterson descubrió que la joven atendía los galanteos de un vecino y que las demoras respondían a esos amores.

La señora de la casa hizo observaciones a Laura sobre su conducta, con motivo de haber regresado tarde en la noche anterior.

La joven quedó muy afectada y se retiró a su habitación.

En la mañana de ayer cuando fueron al $2^{\circ}$ zaguán de la casa, donde se alojaba Laura, vieron el cadáver de ésta pendiendo por el cuello de unos cordeles que había atado en un tirante.

Creemos que la tal familia ha de haber llorado mucho cuando supo que Laura se había dado muerte a sí misma. ¿Y cómo no? La tal familia ahora cuando quiera comer se hará ella su comida (veneno debiera ser) y si no tendrá que pagar a quien se la haga.

Qué libertad ¿eh? La muy... flauta de la tal familia no quería que Laura tuviese amores, ¿por qué?

Tenían miedo de que la esclava se fuese.

Nosotras nos ofrecemos a servir a la familucha, de cocineras sobre todo. Avisen, pues.

\section{S USCR IPCI ÓN}

a favor

\section{DE “LA VOZ DE LA MUJER"}

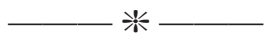

Un billetero 0.05, Una compañera 0.50, Borralla 0.05, Cualquiera 0.20, Quiero botines con cuero Voluntarios a Cuba
0.20, Un gaucho 0.05, Leonardo Pereyra 0.05, La Voz del Anarquista 0.10, Un rabioso 0.10, Barracas Grupo "Los Rebeldes" 1.70 , Una negra blanca 0.10 , Jugados a los dados 0.11, Un chiquilín 0.05, Uno que clavó a "La Nación" en dos meses y medio 0.05, El mismo que clavó a "La Nación" de la venta del papel de la misma 0.35, Ya somos tres 0.30, Mar del Plata Grupo "Las Vengadoras" 1.00, Una revolucionaria 0.20 , L.A. 0.25 , Cualquiera 0.05 .

Lista: N. 4. - Un pittore 0.20, Un socio marinero 0.10, Uno que desea cargar un cañón con cabezas de burgueses 0.10 , Un amigo de Caserío 0.20, Un Mártir de la lesina 0.15, Un desheredado 0.50, Natividad Juanto 0.30 , De la reunión del 8 de Diciembre 1.35, Un herrero explotado 0.25 , A. Summonti 0.02, Dos compañeros 0.05, Otro 0.08, Dos locos 0.06, Anarquista acérrimo 0.20, Un esclavo 0.20, Cualquiera 0.40, Primo aspirante 0.50, Un amigo de Ravachol 0.90, "Natividad" 1.75 , hasta el 28 de Diciembre se ha recolectado 13.07.

Después de esa fecha: Con el puñal en la mano 0.20, Comerciante en burgueses 0.40 , Uno que fuma sin estampilla 0.40 , Uno que quiere la igualdad 0.20 , Viva la dinamita 0.20 , Soy de los revolucionarios 0.20 , Un burgués 0.20 , Uno que quiere bien para todos 0.20 , Uno que confunde su idea 0.10 , M. E. 0.20, Unidos somos fuertes 0.30, Un lavativa 0.20, Admirador de Caserío 0.20, Un canelo fuerte 0.20 , Un faulduo 0.20 , Un explotado 0.20, Blanco 0.20, de esta lista se ha recolectado 4.10 .

E. B. R. 0.50, A. Díaz 0.80, Antonia García 0.30, Acrazia García 0.25, María D. 0.10, Una que está en el camino de la Verdad 0.40, Sobrantes de copas 0.40, Un aragonés 0.20, Cualquiera 0.50, 2 cajas zapatero jodido 0.20, M.G. 0.50, Un herrero explotado 0.20, Un esclavo 0.20, Viva el amor libre 0.50, Reunión 
del 25 de Diciembre 0.65, íd. 29 1.10, id. id. 1,52, Juan 0.40, Un hombre 0.20, Nada 0.30 , Sin nombre 1.20 , lo recaudado es 9,27 .

Total recolectado

hasta el 28 de diciembre

Después de esa fecha

Total

$\$ 26.44$

Gastos por mil ejemplares

de este número

Correos y otros

$\$ 30.00$

$\$ 5.20$

Total de gastos

Déficit

\section{CORRESPONDENCIA ADMINISTRATIVA}

El Perseguido, Capital - La Anarquía, La Plata - La Voz de Ravachol, Capital La Libre Iniciativa, Rosario - El Oprimido, Capital - La Questione Sociale, Capital - La Verdad, Rosario - El Esclavo, Pampa Florida - El Despertar, New York - Derecho a la Vida, Montevideo - La Voz del Rebelde, Zaragoza - El Corsario, Coruña - L'Avvenire, Capital y Le Cyclone, Capital; Os mandamos 5 números, mandad igual si podéis.

Céytun, Mar del Plata. No te olvides de nosotras; manda algo. Retocamos y publicamos "La Donna en la sociedad actual" procura hacer algo mejor para otro número. \begin{tabular}{r|r}
$\$ 35.20$ & A los demás colegas cuya dirección no \\
$\$ 8.76$ & conocemos, les pedimos asimismo el canje.
\end{tabular} 



\section{LA VOZ DE LA MUJER}

Aparece cuando puede

y por suscripción voluntaria
Periódico Comunista-Anárquico
Dirección: A. BARCLA

Casilla Correo 1277 - Capital

\section{¡APARECIÓ AQUELLO!} 米

\section{(A los escarabajos de la idea)}

Cuando nosotras (despreciables e ignorantes mujeres) tomamos la iniciativa de publicar " $\mathrm{La}$ Voz de la Mujer", ya lo sospechábamos ¡oh modernos cangrejos! que vosotros recibiríais con vuestra macanística y acostumbrada filosofía nuestra iniciativa porque habéis de saber que nosotras las torpes mujeres también tenemos iniciativa y ésta es producto del pensamiento; ¿sabéis?, también pensamos.

Apareció el primer número de la "La Voz de la Mujer", y claro jallí fue Troya!, "nosotras no somos dignas de tanto, ¡cá! no señor”, "¿emanciparse la mujer?" , "ipara qué?" "¿qué emancipación femenina ni que ocho rábanos?" "ila nuestra", "venga la nuestra primero!", y luego, cuando nosotros 'los hombres' estemos emancipados y seamos libres, allá veremos".

Con tales humanitarias y libertadoras ideas fue recibida nuestra iniciativa.

Por allá nos las guarden, pensamos nosotras.

Ya teníamos la seguridad de que si por nosotras mismas no tomábamos la iniciativa de nuestra emancipación, ya podíamos tornarnos momias o algo por el estilo, antes que el llamado Rey de la tierra (hombre) lo hiciese.

Pero es preciso señores cangrejos y no anarquistas, como mal os llamáis, pues de tales tenéis tanto como nosotras de frailes, es preciso que sepáis de una vez que esta máquina de vuestros placeres, este lindo molde que vosotros corrompéis, ésta sufre dolores de humanidad, está ya hastiada de ser un cero a vuestro lado, es preciso, ¡oh!, ¡falsos anarquistas! que comprendáis una vez por todas que nuestra misión no se reduce a criar vuestros hijos y lavaros la roña, que nosotras también tenemos derecho a emanciparnos y ser libres de toda clase de tutelaje, ya sea social, económico o marital.

Para vosotros, ¿qué es una mujer fea o bonita, joven o vieja? ¡una sierva, una fregona!

Cuando vosotros, en la terrible y desesperada lucha por la vida inclináis abatidos la cabeza sobre el lacerado pecho, si os salís a disipar vuestro mal humor, cuando en nosotras no lo hacéis, ahí quedan vuestras hembras (para vosotros no somos otra cosa), vertiendo amargo lloro, esto os debe hacer comprender que la diferencia de sexo no nos impide de sentir y pensar.

Ya sabíamos señores infelices que para vosotros una mujer no es más que un lindo mueble, algo así como una cotorra que os halaga, os cose, os trabaja, y lo que es más, os obedece y teme.

¿Verdad señores maridos? ¿no es verdad que es muy bonito tener una mujer a la cual hablaréis de libertad, de anarquía, de igualdad, de Revolución Social, de sangre, de muerte, para que ésta, creyéndoos unos héroes os 
diga en tanto que temiendo por vuestra vida (porque, claro, vosotros os fingís exaltadísimos) os echa al cuello los brazos para reteneros y casi sollozando, murmura “¡Por Dios, Perico!”,

¡Ah! ¡aquí es la vuestra! Echáis sobre vuestra hembra una mirada de conmiseración, de amor propio satisfecho de hidrópica vanidad [y] lo decís con teatral desenfado: "Quita allá mujer, que es necesario que yo vaya a la reunión de tal o cual, de lo contrario los compañeros... vamos no llores, que a mí no hay quien se atreva a decirme, ni a hacerme nada".

Y, claro, con estas "paradas" vuestras pobres compañeras os creen unos leones (para el pan lo sois) y piensan que en vuestras manos está el porvenir social de este valle de... anarquistas de macana.

Claro que con esto os dais una importancia que no digo nada, y como vuestras infelices compañeras os creen unos formidables revolucionarios, claro que os admiran intelectual y físicamente.

Es por esto que cuando tenéis algo que hacer observar a vuestras compañeras os basta con fijar en ellas vuestra fuerte e irresistible mirada, para que éstas agachen tímidamente la cabeza y digan:

¡Es tan revolucionario!

Por esto, sí señores anarquistas cangrejiles, es por esto que no queréis la emancipación de la mujer porque os gusta ser temidos y obedecidos, os gusta ser admirados y alabados.

Pero, a pesar vuestro, ya lo veréis, haremos que "La Voz de la Mujer" se introduzca en vuestros hogares y que diga a vuestras compañeras que no sois tales leones, ni siquiera perros de presa; lo que sí sois es un compuesto de gallinas y cangrejos (extraño compuesto ¿eh?, pues tal sois) que hablan de libertad y sólo la quieren para sí, que hablan de anarquismo y ni siquiera saben... pero dejemos eso, que vosotros sabéis demasiado lo que sois y nosotras también ¿eh?

Ya los sabéis, pues, vosotros los que habláis de libertad y en el hogar queréis ser unos zares, y queréis conservar derecho de vida y muerte sobre cuanto os rodea, ya lo sabéis vosotros los que os creéis muy por encima de nuestra condición, ya no os tendremos más miedo, ya no os admiraremos más, ya no obedeceremos, ciega y tímidamente vuestras órdenes, ya pronto os despreciaremos y si a ello nos obligáis os diremos cuatro verdades de a puño. Ojo, pues, macaneadores, ojo cangrejos.

Si vosotros queréis ser libres, con mucha más razón nosotras; doblemente esclavas de la sociedad y del hombre, ya se acabó aquello de "Anarquía y libertad” y las mujeres a fregar. ¡Salud!

\section{LA REDACCIÓN}

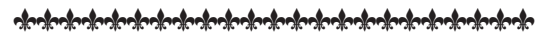

\section{Educación, Amor y OCiseria}

- Señora ¿por qué cruel,

De tal modo castigáis

A ese niño inocente?

- ¿Qué os importa? ¡Impertinente!

- ¿Sois acaso padre de él?

- Su padre no soy mas digo

No lo debéis maltratar. 
- ¿No le he de castigar

Siendo tan mal educado?

- De él la culpa no es.

Es de quien mal le educó.

- ¡Torpe sois! ¿No comprendéis

Que no he podido, ¡hay de mí!

Darle educación mejor?

- ¿Por qué, pues con torpe afán

Le disteis la vida al niño?

¿Fruto no es de aquel cariño...?

- ¡Jamás para mí lo ha habido!

- ¿Pues entonces por qué lo ha sido?

- ¡Por un pedazo de pan!

Josefa M. R. MARTÍNEZ

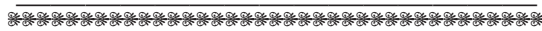

\section{LUCHEMOS...}

Sí, compañeros, ¡luchemos!, tal es la palabra que nuestros labios secos y contraídos pronuncian cada vez que con la mente medimos el camino que por andar nos falta. ¡Luchemos! ¡Luchemos! repetimos, cada vez que fatigadas, pero no abatidas, nos detenemos un instante para recobrar aliento y nuevos bríos.

$\mathrm{Y}$ ¡luchemos! tornamos a repetir a cada vez que un nuevo obstáculo se nos presenta, pretendiendo interrumpir nuestra marcha. Sí, ¡luchemos! repetimos con la serena convicción del que no duda del triunfo.
Hemos principiado a respirar algo de eso que se llama libertad cuando desechando torpes y viejas preocupaciones nos lanzamos a la lucha; lucha terrible y formidable como los son todas las de la libertad, contra la opresión, la de la víctima contra sus verdugos, la de la razón contra la fuerza, las de la civilización contra el obscurantismo (léase religión, pues ésta, el germen es de tal).

Tal vez esta lucha sea superior a nuestras fuerzas, pero ¿qué da? ¿qué nos importa eso? ¡nada! Si caemos será defendiéndonos y con la dulce seguridad del triunfo, pues otras ocuparán nuestros puestos y la de la venganza.

Mujeres de decisión y habituadas a la jamás interrumpida lucha contra el hambre, que negra, cruel y vengativa desde la cuna nos persigue con ensañamiento feroz, ¿qué nos puede importar la cárcel? ¿qué las denigrantes palabras de nuestros enemigos? como de enemigos, el más imponderable desprecio, como de hombres jasco! nos inspiran.

¡Luchemos! sí, exclamamos con rencor fiero cuando oímos el grito monótono (a fuerza de oírlo) ipan! ¡mamá, pan!

¡Luchemos! exclamamos cuando vemos caer empapado en sangre y el cuerpo acribillado de heridas a uno de nuestros compañeros, ¡luchemos!, sí, ¡que hay un crimen más que vengar!

¡Luchemos! repetimos satisfechas cuando vemos rodar ensangrentado el cuerpo de uno de nuestros enemigos.

¿Qué nos importa morir, si en nuestros pechos vive la seguridad del triunfo? ¿qué importa caer?

¡Ah, burgueses, enemigos del bienestar del pueblo, construid cárceles, alzad guillotinas, fusilad y agarrotad! 
¿Qué importa? ¿no saben que de lo más hondo de vuestros calabozos, de lo más alto de vuestras horcas, de lo ensangrentado de vuestras guillotinas, y de los negros y humeantes fusiles sale la fuerza que nos alienta?

Caeremos tal vez, pero el día de la formidable revancha veréis, si alguno de vosotros queda, bajar con raudo giro espesa nube de polvo que con imponderable gozo vendrá a empaparse en vuestra sangre.

¡Serán nuestros átomos los de vuestras víctimas!

Entretanto, anarquistas de ambos sexos: ¡Luchemos!

Pepita Guerra

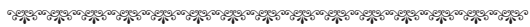

\section{A LOS CRítICOS}

\section{- *}

Para que se vea que no sólo nosotras, sino muchas más, comprenden el triste estado y pésima condición de la mujer insertamos:

"¿Cómo pues sintiendo en mí algo de Águila había de pasar tan hondas, monstruosas y sangrientas iniquidades, sin hundir mis garras en ellas, y sin agitar mi vuelo en derredor para que se disipe en lo posible, el aire pestilente que envenena las almas de las desgraciadas mujeres?"

"De esas mujeres bárbara y miserablemente presas por leyes arbitrarias y costumbres en pugna con los principios de la pura moral; INSPIRADAS Y PROTEGIDAS POR SECTAS FARISAICAS que, nombrándose pomposamente emancipadoras de la mujer, no intentan otra cosa que sumirla en la mansedumbre y resignación de los siervos; anulando su voluntad con torpes halagos; embruteciendo su entendimiento con viles concesiones; empequeñeciendo su espíritu con groseros artificios, llevando sus aspiraciones hacia todo lo mísero, lo vano, lo inútil, y haciéndola temer o despreciar lo positivo, lo beneficioso; entregándola al hombre no como su compañera, sino como su hembra, y para mayor escarnio recomendándole la consideración hacia ella! ¡Cómo si en un concubinato, y lo es la unión de dos almas desemejantes, pudiera haber otra cosa que tirano y sierva!

Condición real del alma de la mujer en manos de esos séides del autoritarismo, los cuales no cesan en sus propósitos, hasta no rendirla sumisa y dócil como torpe bestia, en una conformidad sin límites, inagotable, que la entrega indefensa, y lo que es más horrible, satisfecha, al soberbio amor propio del hombre, sin dejar otro medio de apelación a los ultrajes que recibe, que una astucia de culebra, y el envilecimiento de ciertas venganzas!

¡Oh! que no le fuera dado a $\mathrm{mi}$ voluntad el poder de emitir una voz tan penetrante como dicen que será la de la trompeta apocalíptica, para que a sus voces, se levantasen los cadáveres de las almas femeninas y aunque fuera desgarradas y corruptas se alzasen en impotente muchedumbre, reclamando justicia ante la conciencia universal.

\section{Rosario de Acuña}

Estúdiese este artículo y reflexiónese y se podrá formar una idea de nuestra condición social. 


\section{¿Amemos? no ¡Luchemos!}

¿Qué tienes, tierna e inocente niña? ¿Por qué el rubor cubre tus mejillas? ¿Por qué estás agitada y vergonzosa? ¿Qué tienes? ¿Qué sufres?

¡Ah! no lo digas, no, no lo digas, ya he comprendido cuál es tu situación, cuál el pesar que te aqueja. Ya sé por qué a veces tus ojos son un raudal de lágrimas en vez de ser un foco de radiante luz.

Ya sé también por qué tus mejillas se cubren de pronto de un vivo carmín. Sí, niña ¡tú amas!

¿Y por eso te avergüenzas y te muestras tan apesadumbrada? ¡Ah! ¿Te han dicho que es una "falta" decirle al objeto de tu amor que le amas?

¿Qué tú crees que es cierto que debas fingir, ser hipócrita? ¿Crees que tu amor te deshonra? ¿Crees que no tienes derecho a sentir amor hasta que te lo confiesen a ti?

No lo creas niña, no, te han engañado, se burlaron cruelmente de tu cándida inocencia. Sí, te han engañado, porque tu amor lejos de ser un crimen, es todo lo contrario. ¡A Amar es vivir!

¡Amar es la ley de la existencia!

¡Ama, pues, niña, ama con toda la fuerza de tu juvenil y tierno corazón! ¡Ama!

¡Ama! sí, y con tu amor embellece y llena de encanto, de dicha, de felicidad y de magia la existencia del dichoso objeto de tu amor.

Ama, y con tu amor endulza tu existencia, y todo cuanto te rodea. Ama y sé amada. ¡Amar y ser amada, es ser feliz!
¿Por qué vacilas, pues? ¿Qué te detiene? Ama, niña, que la existencia te sonríe.

Fija tu mirada en la mirada de aquel que sin saberlo te magnetiza; rodéale el cuello con tus ebúrneos y redondos brazos, aprisiónalo en ellos y al compás cadencioso del ondular de tu virginal seno que promete un mar de mágicos deleites, murmura quedo, muy quedo, a su oído: ¡Yo te amo !.. díselo y verás cómo cae a tus pies, loco, loco y enajenado de amor y placer!

...Pero no, niña, no se lo digas, no se lo digas, porque él creerá que eres una loca, ¡oyes? ¡una loca! y lo contará a sus amigos en la calle, en el taller, en el hogar, en fin, y entonces ¡ay de ti! niña, ¡ay de ti! ¿Adónde irás que la rechifla no te siga?

¡Oculta pues tu amor, ocúltalo cual una asquerosa lacra, ocúltalo cual si fuese un crimen!

Busca en la masturbación un lenitivo a tus voluptuosas ansias. Hazlo todo, todo, menos amar hasta que te amen, ¿sabes? porque nosotras no somos seres que puedan y deban sentir hasta que nos lo permitan, del mismo modo que el cigarrillo no pide que lo fumen y espera a que su poseedor quiera "usarlo".

No se lo digas, por favor, niña, no se lo digas, que si se lo dices y acepta las primicias de tu cuerpo, gentil y esbelto cual la gallarda palmera del "oasis" del desierto, qué harás luego cuando la estupidez de tus padres y parientes te insulte y escarnezca, porque creerán que tu amor los llena de ignominia, despreciada e insultada por esta sociedad; mofada por tus ex com- 
pañeras, que en su ignorancia creerán también una falta el más grande y noble de los sentimientos: ¡el Amor!

¿Qué harás entonces desamparada y sola entre el inmenso número de seres que te rodearán? ¿A dó irás, cuando aterida de frío o desfalleciente de calor, te halles sola, muy sola, sin pan para ti, sin leche para tu hijo y sin techo en que cobijarte? Sin una voz que te aliente, ¿adónde irás con tu hijito en brazos? ¿A mendigar? ¿Lo arrojarás a un potrero?

¿Lo arrojarás a una casa de esas llamadas de Expósitos?

¿Venderás tu cuerpo, que aún esbelto, codiciarán?

¡Ah! no niña, ¡no hagas eso, niña, que no sabes con qué saña feroz, con qué cruel encarnizamiento te perseguirá la sociedad repleta de virtuosas y elegantes damas, de religiosas y piadosísimas matronas, mujeres que son quizá esposas, hijas o madres de aquellos mismos que comprarían tu cuerpo y lo cubrirían de cieno, de ese cieno babeante, corruptor y nauseabundo, que corre en forma de pequeños arroyuelos debajo del aristocrático frac y de la elegante vestimenta de las señoras tal y cual!

¡Ah, si tú vendieses tu cuerpo para tener pan, ya verías a esas matronas, esas mismas que para sí tienen un marido y diez amantes, esas mismas que en los apartados y lujosos gabinetes paternales de la señorial mansión se entregan con rabioso y erótico furor al noble y elevado ejercicio de la masturbación, escarnecerte y con frenesí inhumano tratar de arrojar sobre tu cuerpo un poco del mucho pus que en el de ellas tienen!
No ames pues niña, no, sé hipócrita, rastrera y vil, acepta al primero que se presente, ¿qué importa que el tal te repugne? siempre podrás hacer lo que las grandes matronas, un marido para el lecho y diez queridos para todas partes.

Pero antes, niña, oye: Si como nosotras tienes fuerte el ánimo y sereno el corazón, ven con nosotras, apártate de la tiniebla y vamos hacia donde el vivo fulgor de la naciente luz nos anuncia el nuevo día.

¿No lo ves brillar, ya en lontananza? ¿Ves aquello que de entre las sombras se destaca? ¿Ves cómo irradia en torno diamantina claridad?

¡Mírala! ¡mírala! ya se acerca a pasos agigantados.

¿La conoces? es la Anarquía. Sí; es ella que nos trae paz y libertad, igualdad y felicidad para todos.

¡No temas, no, por que veas que en su izquierda chispea una antorcha y en su diestra blande un puñal, si tal trae, es porque tiene que abrirse paso por entre tinieblas, y porque en ellas anida el cuervo, el grajo y el vampiro, o sea la religión, la ley y el poder; la Burguesía, en fin!

$$
\text { * }
$$

¡Jóvenes, niñas, mujeres en general, de la presente sociedad!

Si no queréis convertiros en prostitutas, en esclavas sin voluntad de pensar ni sentir, ¡no os caséis!

Vosotras, las mujeres, ¿qué somos? ¡algo! ¿qué se nos considera? ¡nada!

Vosotras las que pensáis encontrar amor y ternezas en el hogar, sabed que no encontraréis otra cosa que un amo, un señor, un rey, un tirano. 
El amor no puede ser eterno ni inmutable y fijo, luego si éste tiene un término, ¿qué queda en esa impía institución que dura lo que la vida? ¿qué quedará, cuando el amor termine, de vuestro matrimonio? fastidio, tedio, y como es natural la prostitución.

Sí, la ley natural nos impele a amar continuamente; no nos impele igualmente a amar el mismo objeto, no, y entonces, ¿por qué permanecer sujetas a tal o cual hombre para toda nuestra vida?

Miles de casos se ven en que una infeliz mujer huye del hogar marital, no quiero saber por qué causa, sea ella cualquiera, el caso es que el marido acude a la autoridad y ésta obliga a la esposa a ir nuevamente al lado del hombre a quien detesta y odia.

¡Más no hiciera un pastor con una oveja o una cabra!

Yo no digo que en la presente sociedad pueda una mujer tener el grado de libertad que anhelamos, pero sí que en nuestra futura y próxima sociedad, donde nada faltará a nadie, donde nadie padecerá hambre ni miseria, allí sí que querremos el amor libre completamente. Es decir que la unión termine cuando termine el amor, y que si yo porque la gana me da, no quiero estar sujeta a ningún hombre, no se me desprecie, porque cumpliendo y satisfaciendo la ley natural y un deseo propio tenga un amante y críe dos, cuatro o los hijos que quiera.

En la sociedad presente no lo hago, porque como yo no quiero ser la fregona de ningún hombre y no siendo suficiente mi salario para mantenerme a mí, menos a mis hijos, pues yo creo que si los tuviera, me vería obligada por huir de ser la hembra de uno o ser la de diez más.
Por otra parte, no creáis que la crítica me importe, yo no soy de aquellas que tienen la desvergüenza de querer tener vergüenza.

Es por eso que yo no pienso jamás enlazarme con nadie, ni tampoco ( $s i$ llega el caso), ahogar en mis entrañas para conservar la negra honrilla al fruto de mi amor o momentánea unión; quede eso para "la distinguida" niña fulanita que va (en tiempo de invierno) a reponer su apreciable salud a la estancia de tal o cual, y que [a] los pocos meses ¡oh prodigio! vuelve sana y desembarazada de la pícara enfermedad que la aquejaba.

Es por esto, queridas compañeras, que yo digo y pienso que a los falsos anarquistas que critican la iniciativa vuestra de proclamar el amor libre, quisiera tenerlos a mi lado para cuando, desgarradas las entrañas, estuviera próximo mi postrer aliento, para escupirles al rostro, envuelta en una baba sanguinolenta, esta frase: ¡MARICAS!..

Sea lo que quiera.

Adelante con "La Voz de la Mujer" y con el amor libre.

¡Viva la Anarquía!

Pepita Gherra

\section{¡PUERCOS!}

Recortamos del periódico cochinosocialístico burgués, La Vanguardia, del 12 de enero:

La policía está a las órdenes de los patrones para conducir preso al traba- 
jador que instigue a sus compañeros a dejar el trabajo, aunque lo haga por los medios más lícitos.

El delito lo inventa el patrón, su sola palabra lo prueba, y la policía se complace en creerle y en encarcelar a los huelguistas. Para eso se movilizan escuadrones enteros de vigilantes y se los ostenta como una provocación insolente a los mismos que todos los días pagan los impuestos con que se costean esas fuerzas.

Un hecho.

"El delito lo inventa el patrón”... y vosotros, señores ¿qué hacíais en el embrión de reunión que tuvísteis en Barracas en la calle San Patricio? ¿Por qué teníais la policía a la puerta y mandábais preso todo aquel que no tenía cara de pavo?

Vamos, ¿a qué tantas vueltas? para ser diputados no se necesita empezar por ser cirineos de la burguesía, pero callamos, ya todos sabemos que socialistas y burgueses sois dos porquerías distintas y una sola calamidad ambiciosa. ¡Ah, congresiles!

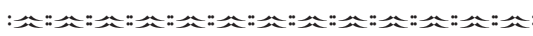

\section{AGARREN ESA MOSCA POR EL RABO...}

Hablando de las huelgas, dice un sabio colaborador oficioso del no menos "sabio" diario La Tarde de La Plata :

"Entendemos la razón de estas huelgas en países donde el obrero gana un franco, o 1,25 diarios, con lo que tiene que sostenerse él y su familia. Donde se explota el sudor y la salud de estos infelices en beneficio de empresarios que levantan inmen- sas fortunas en pocos años. Pero aquí, en la República Argentina donde un obrero gana 3 pesos y puede vivir cómodamente con uno, ahorrando de esa manera 2 pesos diarios, es injusto, es incalificable y hasta criminal."

¿Qué les parece a Uds.?

A nosotras... también.

Vean Uds. donde este tío viene a confesar que en Europa se explota los obreros.

Pues aquí viene a ser igual y si aquí les pagan hasta tres pesos y allá sólo 1,25 , la diferencia está en el costo de la vida.

Tan ladrones son unos como los otros.

En cuanto a lo de comer, ya no decimos vivir con un 1 ps. Lo hará él porque los papa moscas...

$\cos \omega \cos \omega \cos \omega \cos \omega \cos \omega$

\section{Dios, Ley y Comercio}

Mil veces he tenido ocasión de escuchar de los labios de algunos ignorantes obreros, éstas o parecidas palabras: Sí, pues no, ustedes dicen que todos los patrones son ladrones, porque ganan más que Uds., pero es porque no quieren Uds. darse cuenta de los gastos que tienen todas las personas que tienen un "negocio".

Últimamente, y por falta de tiempo, he dejado pendiente una discusión sobre este tema con varias compañeras, y voy a contestarles.

Yo, queridas compañeras, y conmigo todo anarquista, sostenemos que cualquier negociante, sea pequeño o grande, es un ladrón.

Ya hemos tenido en cuenta eso que 
vosotras con vuestro criterio mal formado llamáis gastos, etcétera.

Bien sabemos que cualquier aprendiz de ladrón, o sea bolichero, tiene más gastos que nosotros: alumbrado, seguridad pública, etcétera.

Bien sabemos nosotros que la sociedad actual nos obliga a ser explotados o explotadores y es por eso que nos hemos rebelado contra ella y sus estúpidos defensores.

Veamos, cualquier patrón nos robará el producto de nuestro trabajo, en su mayor parte: si producimos ocho nos dará dos. Bien, como pudiera ser que algún hambriento quisiera apoderarse y se apoderase de aquella parte que el patrón robó al obrero, hubo necesidad de pedir favor al gobierno, que es el defensor de los ladrones, y éste le dijo: "Bueno, yo te prestaré auxilio, yo impediré que tus infelices víctimas traten de sacarte lo que tú, por medio del engaño y valiéndote, y aprovechándote de su ignorancia, le has robado, yo cuidaré y defenderé el producto de tus rapiñas, pero con la condición de que tú me has de dar una parte de lo que robas".

Y efectivamente, se estableció vigilancia por todas partes y esta vigilancia costaba al burgués, o sea al ladrón, un peso, de los seis que había robado.

Apercibido el burgués de que el fruto de sus robos había menguado, dijo al gobierno:

"Pero hombre, así de este modo tú sin más trabajo que haberlo pensado, vienes a disfrutar de una parte de mis ganancias y por lo tanto éstas disminuyen en una parte muy considerable, lo cual no me conviene de ninguna manera."
- "Tonto, le respondió éste, si tú antes le pagabas dos por lo que te producía a ti ocho, ahora págale uno y asunto concluido."

Vino luego la Iglesia, y sus comerciantes, conocido el juego que al obrero le habían hecho, pidieron y obtuvieron también su parte del producto del robo, encargándose ellos de hacer creer que el dios que ellos invocaban prometía mil y mil goces para la otra vida. ("A burro muerto cebada al rabo".) Y que aun cuando este mundo estaba lleno de injusticias había que soportar éstas con resignación y esperar buena ventura allá en el otro mundo.

Así, con éstas y otras pamplinas, estuvo engañado el obrero por luengos años y sus explotadores viviendo "honesta" y "honradamente" del fruto de sus "negocios", o sea rapiñas. Como es natural, los que estaban encargados de velar por la seguridad y el orden social, maliciaron la cosa también y dieron en rezongar, y pedir una parte más en el botín del robo, y hubieron de concedérsela.

Pero entonces sucedió que apercibido el obrero de que había quien comía y no trabajaba, mientras que él trabajaba y no comía, preguntó a sus camaradas por qué era aquello así, cuáles las causas; ninguno hubo que le respondiera, y si lo hubo sus respuestas y explicaciones no complacieron al obrero.

Pero he aquí que, apercibidos los comerciantes del Dios de la curiosidad del obrero, se presentaron a ellos, prometiéndoles satisfacer su curiosidad, y luego de escupir y toser varias veces, encaramándose a un cajón lla- 
mado púlpito, comenzaron a embaucarlos por su cuenta, comerciando con "Dios".

Mientras esto sucedía, el gobierno allí presente cuchicheaba con el burgués y se reían ambos de la estupidez del obrero.

Aconteció que estando en esto se presentó un nuevo farsante y dijo: "no obrero, no hagas caso de lo que este comerciante con 'Dios' te está diciendo, yo sé la causa de esta enfermedad y conozco el remedio. Yo te prometo que, si tú quieres que yo gobierne, yo haré lo que tú digas y mandes, y mediante que tú me pagas un tanto yo aplicaré el remedio, tu..."

Un terrible clamoreo interrumpió al embaucador, gritos de protesta, furiosos alaridos. Eran los que vivían "honesta y honradamente" del fruto del trabajo del obrero, que temerosos de que se les escapase el turrón gritaban y amenazaban.

El obrero indignado tomó un palo y se dispuso a romperles algo importante a los dos que lo engañaban, al "gobierno" y al ladrón, o sea a los dos ladrones. Mas como el gobierno tenía a sus espaldas a aquella gente que hacía de seguridad pública, tuvo el obrero que luchar fuertemente con ambos y una vez vencedor, dio poderes para que le hiciese leyes al otro embaucador, y a unos otros, que se llamaron diputados, etcétera.

Tuvo el obrero que pagarles, darles de comer y vestirlos a los tales diputados y demás chusma y éstos por su parte hacían mil macanazos que llamaron leyes y con las cuales estuvo el obrero largo tiempo engañado, hasta que un día se presen- tó del otro lado del río el gobierno anterior, que envidioso al ver la vida que se daban los que hoy gobernaban al obrero, se presentó, seguido de los que habían sido guardias cuando él era gobierno, y además venían con él otros obreros de otras partes que él había engañado, diciéndoles que los que estaban de este lado del río pretendían esto y lo otro y que no eran hombres cual ellos, porque llevaban el sombrero de este modo en vez de llevarlo del otro.

Apercibidos los ladrones del lado de aquí de la presencia de los ladrones del lado de allá, prorrumpieron en desaforados gritos y feroces aullidos, diciendo que los de allá venían a profanar las tumbas y a echar a "Dios" de los altares, etc., y saltando al medio de la calle un negociante con "Dios" prorrumpió en los gritos de ¡la Patria!... ¡la patria! Nadie entendía lo que él decía, pero como el negociante con "Dios" había hecho una seña a los diputados y al gobernante, éstos comprendieron que era una nueva forma de embaucar y comenzaron a decir mil y mil brutalidades sin pies ni cabeza, sobre la cuestión "patria", que para ellos era cuestión "panza".

Salió nuevamente el embaucador de antes y dijo: la "salud" de la "patria" y la libertad "vuestra" está en peligro y es necesario defenderla, yo y los que os gobernamos no podemos ir a luchar, porque si fuéramos quedarían nuestros intereses perjudicados por el abandono y no tendríais quién os gobernara, ni os dirigiera; así que ahora es necesario que me déis tanto para comprar armas y tanto para mandaros hacer unos trajes que sean todos 
iguales, para poderos conocer, y que no os matéis unos a otros, creyendo que sois enemigos.

A causa de esto tuvo la clase de obreros unos cientos de soldados que habiéndose acostumbrado al pillaje de la guerra y además porque como el hambre que sigue a toda guerra se había manifestado con toda su desnudez, y muchos hambrientos trataban de apoderarse de lo que les habían anteriormente robado, el gobierno los quiso tener a su lado para defender a los burgueses el producto del robo, para así poder él seguir disfrutando de su parte que en forma de sueldo o salario le daba la burguesía; y como el pueblo se quejara, el gobierno contestó:

"Estos hombres los tengo porque es preciso tenerlos preparados para el día que suceda lo que ayer. Y el gobierno dio en hacer simulacros de guerras con los gobiernos de las otras aldeas para tener asustados a los obreros. Y sucedía que cuando el pueblo se quejaba, el gobierno declaraba una guerra y los hacía ir a que se mataran, para librarse de ellos."

¿Quién paga todos esos gastos para sostener escuadras, ejércitos, generales, diputados, frailes, ministros, policía y demás chusma? El comercio, dice el gobierno iy el comercio con qué comercia? con el producto del trabajo de los obreros, digo yo, porque por mucho oro que yo tenga, con llevarlo de un lado para otro, éste no produce nada, ni papas siquiera, y por muchas vueltas que yo le dé a un cajón de arroz, comprándolo a uno vendiéndolo al otro, éste no aumenta y si yo trabajo mucho, con el tal cajón es lo mismo que si no trabajara, puesto que nada produce, y tanto valdría empeñarme en dibujar en el agua, o en escupir al cielo, trabajaría mucho y gastaría mis fuerzas y sin embargo si comía lo había robado.

Comerciar es robar.

¡Viva la anarquía! ¡Abajo la explotación!

Milna Nohemí

(Mar del Plata)

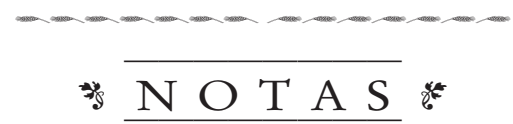

\section{A los compañeros}

Nuestra dirección desde la fecha la hemos fijado de la siguiente manera: A. Barcla. Casilla de Correo 1277.

Así, pues, para todo lo referente a La Voz de la Mujer dirigirse a la referida dirección y no a otra ninguna anterior.

\section{En Barracas}

El día 19 del presente, en circunstancias de estar reunidos unos cien compañeros, nos dicen en el local de la Sociedad de Obreros Albañiles, se presentó un perro (sin collar) a preguntarles quiénes eran, qué hacían y por qué estaban allí...

Parece que los compañeros no lo recibieron muy bien, pues el tal can prudente y mansamente se retiró.

Terminada la reunión, los compañeros dirigiéronse a un café próximo en donde en número de treinta más o menos fueron rodeados y llevados presos por unos 80 perros de todas especies (los había ñatos, rabones, galgos, de terranova y "chinos" sobre todo). 
Estos compañeros se encuentran actualmente en el depósito de contraventores 24 de Noviembre y entre ellos dos heridos.

Lo que nosotras extrañamos es que hayan recibido tan mal a la policía tanto en el local como en el café, dando lugar a que ésta tenga que quejarse de la conducta de los compañeros de Barracas. Sí, compañeros; no debisteis dar lugar a quejas, y aquí viene a pelo aquello de: "Los muertos no hablan" ni se quejan, compañeros...

\section{El Divorcio}

A la compañera Lareva le avisamos que hemos perdido el original de "El Divorcio", y por tal causa no podemos publicarlo.

\section{Por la patria}

Leemos en "La Prensa" del 13 del presente de una correspondencia de Italia :

"Detrás de los batallones en marcha corrían sin cansancio, sin reparar en obstáculos, venciendo todo impedimento muchas pobres mujeres, sin una lágrima en los ojos, pero con el más profundo dolor estampado en sus facciones.

Eran madres que corrían hasta el muelle para dar el último beso a sus hijos, y aunque alguien quiso detenerlas, nadie se atrevió a rechazarlas.

Bajo la lluvia continua comenzó el embarque."

¿Y cómo se llama esto? Desfiles de tropas expedicionarias dicen. "Pobres mujeres" el último "beso" de sus hijos.
¡Oh! ¡madres, criad hijos que la patria se encarga de ellos!

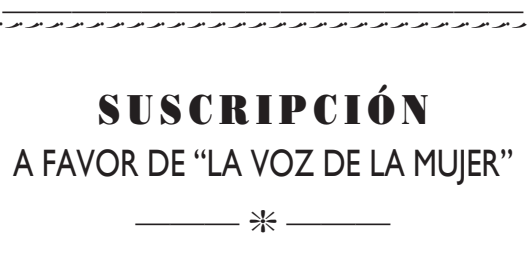

De la Boca. Un compañero argentino 1.70 , Uno che non si ferma 0.30, Un malato 0.40, Un zapatero C. 0.30, Un giovane che vuol dividere 0.20 , Io attendo la vittoria C 0.20 , Un compagno di rapiña 0.50 , Viva l'unione 0.50 , Un disgraziato 0.35 , Viva l'eguaglianza 0.50, Plommanti 0.50, Tessino 0.10, Bacco 0.40, Ribelli 0.60 - Total de esta lista son ps. 6.55.

De Barracas. Por conducto de un compañero M.V. 0.70, Un herrero explotado 0.50 , Un principiante 0.50 . Total de esta lista son ps. 1.70 .

De San Isidro. Hacha y veneno 0.20, Vizconde de Brangelone 0.20, Una serpiente para devorar Burgueses 0,20. Total de ésta son 0.60.

De la Capital. E. M. 0.50, Modesta M. Lomes 0.20, Dominga Lomes 0,20, Pedro Carabeli 0.25, Anarquía 0.30, Esclava 0,15 , Un propagandista 1.00 . Total de esta lista pesos 2.70.

Por conducto de Calvo. A mí, ¿qué? 0.10, ¿Qué me importa?... 0,10, Gran cosa... 0.10. Cómo no, 0,10, Ba... baba... ba... 0.03. Total 0,45.

Por conducto de Canano. Resto de una convidada 1.30. Por conducto de Salvans de la reunión de 17 de Diciembre de 1895 2,30, Total ps. 3.60 .

Barracas. Grupo 3 bochas 1.50, Titta 0,50, Uno que le gusta el Paraguay 0.15, Reunión del día 14 de enero 0,88, Giorno 0,20. Total ps. 3.23.

Chivilcoy. L. Arroyo 0,10, Reunión del 10 de enero recolectado 0,80 , Sin nombre 
0.15, Francisco M. García 1.00, Recogido en una barbería de la calle Defensa. Un arrotino 0.20. Total de ésta ps. 2.65.

Recibido por un compañero. Un favabruto 0.20, Miguel Juan 0,25, Sans Culottes, 0,20, Un Anarquista 0,20, Sobrante de cerveza 0,55 . Total de ésta 1,35 .

Y lo recibido fue 1,55 (sobran 20).

Ayacucho. Uno que quiere la R. Social 0,50, Uno que se llamaba Rosoffsente 0,50 . Total de ésta ps. 1.00 .

De las listas repartidas en la reunión del 16 de enero.

Lista Núm. 2. Demetria Santamaría 0,20, Obdulia Santamaría 0,20, Teresa 0,50, Josefina Estrella 0,50, Martina Sáenz 0,20, Elvira Sateuri 0,20, Martina Arrieta García 0,20, Antonia García 0,20, Acracia García 0,20, Josefa 0,45, L. A. 1,00. Total de esta lista 3,85.

Lista Núm. 4. Peppa M. 0,50, Giggia M. 0,50, Morni M. 0,50, A. M. 0,20, P. M. 0,50 , Juri Tauz 0,20, Mariutta 0,20, Siora Peppe 0,05, La fia di pippeta 0,20, Corista 0,25, Una beghina 0,15, Il Lampo 0,20, C. E. 0,25, A. C. 0,10, Aburrido 0,10, Martínez 0,10, Viuda de Salvador 0,10. Total de esta lista ps. 4,10.

Entregado en nuestra redacción por el compañero Calvo.
Resto de una convidada en un almacén de la calle Santiago del Estero 0,53. De Mar del Plata por conducto de Pérez 1,00. Total entregado por Calvo 1,53.

Por conducto de Le Cyclone. Clementina 0,25. Por conducto de Bujda Inocente Nalda 0,05, María Ramos 0,05, Sarampión 0,20 . Total las dos 0,55.

Por conducto de La Questione Sociale. Francisco Serrano ps. 1,00, Marat 0,40, el 33 0,25, G. Ch. 1,00, A. Pagés 0,15, Antonio Ruescas (Rosario) 0,50, Un aprendiz 0,15, Juan Pelli 0,50. Total de ésta 3,95.

$$
\text { Total lo recolectado es } \quad 37,81
$$

Gastos:

$$
\text { Por } 1000 \text { ejemplares }
$$

$$
\text { de este núm. } \quad 30.00
$$

Pago de la casilla por 6 meses $\quad 6,00$

Expedición, papel sobre y otras $\quad 9,05$

Déficit anterior $\quad 8,76$

$$
\text { Total Gastos } 53,81
$$

Déficit de este número $\quad 16,00$

Nota: Por falta de espacio, no publicamos la lista de suscripción para la hija de Salvador y otras compañeras.

La Redacción 



\section{LA VOZ DE LA MUJER}

Aparece cuando puede y por suscripción voluntaria
Periódico Comunista-Anárquico
Dirección: A. BARCLA

Casilla Correo 1277 - Capital

\section{Firmes en la Brecha}

\section{(A Nuestros ENEMIGOS)}

"...Salimos a la lucha... sin Dios ni jefe..."

N. 1 de La Voz de la Mujer

Como lo habíamos sospechado resultó. Tales fueron nuestras palabras cuando hemos notado la general polvareda levantada con motivo de nuestro editorial del N. 2.

Atacadas indirectamente, aunque sin razón, cuando el N. 1 vio la luz pública, decidimos no dejar pasar dichos ataques sin responderlos como era debido. En efecto, así lo hicimos, pero con tan mala suerte que debido a una confusión (por falta de ampliación) en la redacción del escrito, se ha descolgado sobre La Voz de la Mujer una verdadera tempestad.

No obstante este primer tropiezo no nos intimidamos. Hemos dicho al aparecer en el palenque del periodismo "mas como no queríamos depender de nadie, alzamos nosotras un girón del rojo estandarte; y salimos a la lucha... sin Dios y sin jefe".

Ahora bien. ¿Cómo podéis creer que estando decididas como estamos, íbamos a sujetar nuestra línea de conducta a las opiniones de Juan, Pedro o Pelayo? ¿Habéis creído por ventura que porque vosotros hayáis tachado nuestra hoja de inmoral los unos, y de insensata los otros y porque cada cual en uso de su voluntad nos haya juzgado como quiso habíamos nosotras de abdicar de nuestras ideas, de nuestra manera de pensar y obrar? Seríais vosotros más que insensatos si tal creyeséis; sin embargo, tentadas estamos a creer que así lo habéis pensado cuando os atrevisteis a lanzar pensamientos por demás absurdos como son los que a citaros vamos.

"Esto no puede ser... Ésta no es manera de escribir, no se pueden tolerar semejantes provocaciones de parte de esas mujeres." "Es necesario que ese periodicucho desaparezca", etc., etc. Linda manera de pensar ¿no es cierto ? ¡Bonito respeto a la Autonomía individual!

¡En nombre de la Anarquía hacer la guerra a un periódico que al venir a la lucha periodística, vino dispuesto a no transigir con nada ni con nadie en lo referente a defender la emancipación de la mujer, uno de los grandes y bellos ideales de la Anarquía!

Los que habéis hablado, ¿estudiasteis bien lo que es la Anarquía? ¿No será ella quien asegurará nuestra más completa libertad individual, una vez que haya triunfado? ¿No será ella la que pondrá a la mujer a la altura del hombre?

Y si comprendéis esto, como creo lo comprenderéis, ¿por qué os servís de la palabra Anarquía para cortar nuestra libertad de pensamiento y nuestra libertad de acción y en nombre de esa misma Anarquía nos lanzáis, para inti- 
midarnos, amenazas por demás ridículas por el solo hecho de ser mujeres?

Tenedlo bien entendido que toda vindicación lleva consigo el delito. Es cierto que hay excepciones, pero éstas no forman reglas. Es por esto, pues, que los falsos Anarquistas se han creído ofendidos, pusieron su grito en el cielo, como la fiera herida por el cazador.

Debemos advertir también a todos los compañeros que al poner el escrito de Redacción de nuestro número anterior, no nos impulsó el deseo de constituirnos en las feroces de lengua y pluma, como muchos han dicho, ni tampoco nos dirigimos a todos los anarquistas en general, sino a algunos individuos que titulándose revolucionarios han tratado de desvirtuar el objeto de esta modesta hoja y que no teniendo sin duda energía suficiente para atacarnos de frente, nos zahirieron por la espalda.

Queremos la lucha franca y leal y por eso la hemos provocado, al conocer se nos atacaba. He aquí todo.

Pero, a pesar de toda vuestra guerra, seguiremos firmes en la brecha dispuestas a mantener bien alta la bandera de la intransigencia pese a quien pese y duélale a quien le duela. No [iremos] jamás a pedir a nadie su parecer sobre nuestra línea de conducta, nos mantendremos firmes en nuestra divisa, cumpliendo nuestra más completa autonomía individual dentro de los ideales del Comunismo y la Anarquía. Esto se entiende también que lo efectuaremos en lo que la actual sociedad burguesa nos permita.

Ahora compañeros y compañeras: Todos aquellos que estéis conforme con nuestra línea de conducta, espe- ramos que nos prestéis la mayor ayuda posible para poder echar en cara a la Actual Sociedad Burguesa todas sus bajezas, todas sus infamias, y lanzar al rostro de los tiranos de la Humanidad el lodo que nos pretenden arrojar a los proletarios y a las proletarias.

Y para terminar ésta por demás enojosa cuestión diremos que si nuestro periódico no puede salir cada mes, saldrá cada dos y si no cada tres meses, y si por desgracia llega a suceder (que creemos no sucederá) que el número de nuestros adversarios llegue a aumentar hasta el extremo que nos obliguen a desaparecer de la lucha periodística, sabed que caeremos pero sin arriar nuestra bandera.

Ya lo sabéis, pues. ESTAMOS FIRMES EN LA BRECHA.

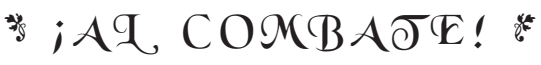 ...........}

¡Valientes camaradas! ¡Alzaos! ¡ya es [la hora!

La voz de las acciones llamándonos está:

Del día de la lucha se anuncia ya la aurora ¡El día de la venganza por fin clarea ya!

Las lóbregas tinieblas disipa el nuevo día El mundo iluminando su luz matutinal Mostrándonos airada la torpe burguesía ¡En sangre obrera tinta su mano criminal!

Oíd: por donde quiera los gritos de [venganza Retumban estridentes ¿lo oís? “¡Venganza, [sí!”...

Son cortos los instantes el plazo ya se [alcanza ¡Que rueden mil cabezas y mil y mil y mil! 
Del antro oscuro impío do yacen los [obreros

Que mártires han sido de nuestra [redención

El eco nos repite " $¥$ Ya es hora [compañeros!"

“QQue atruene los espacios la voz de [vuestra acción!"

Y la infeliz obrera que con aleve mano Ha sido sumergida del vicio en el pilón

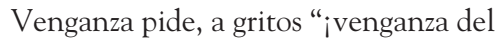
[tirano"...!

“¡Venganza, hermanos míos no haya [compasión"!...

En huesos insepultos del mártir del trabajo Que de hambre ha sucumbido en el

[tormento atroz

En nombre del derecho que para vivir trajo ¡Venganza pide el viento al discurrir veloz!

De mil hambrientos niños las voces [quejumbrosas ¡Matad! ¡Matad! nos dicen, al déspota ruin Y alzadas sus manitas señalan temblorosas La raza innumerable del Bíblico Caín!

¡Valientes camaradas! si el corazón os late ¡Alcémonos! Ya es hora cesemos de gemir No más llanto ni quejas. Corramos al

¿Que aun siendo vencidos nuestro es el [combate [porvenir! Josefa M. R. MartÍnez

\section{¡ASOMBRAOS!}

\author{
一米 -
}

Del caos gigante levantándose entre inmenso y brumosos cendales fulguran como antorchas, esplendentes, las inmortales sombras de los que llevando tras sí las descompuestas muchedumbres vivieron.
Las cerúleas ondas en cuyas cabrillean los pálidos rayos de la argentada y melancólica antorcha del espacio, que rasga con sus millones de rayos las lóbregas tinieblas nocturnales, ruedan y ruedan y ruedan sin cesar arrullando en sus profundos senos misteriosos, las innúmeras poblaciones que en ellos se nutren al cadencioso compás del susurrar rítmico y armónico de las nereidas, tritones, náyades y algas que su mansión tienen en alcázares de millones de estalactitas construidos, cuyas cúpulas jamás imaginadas componen perlas, nácares y millones de millones de burbujas!

¡Siempre inmutable, siempre asombroso en su inmensa y aterradora extensión, en tanto que a sus riberas, majestuosos y serenos pasan los bardos, a cuyos la Caliopea musa del Pindo, como don sublime concedió el Laúd o la Lira de inmortales cantos, que con plectro de oro tañen!

¡Allá va! ¡la pléyade de los Camoens, Schiller, Hugo, Wagner, Verdi, Goya, Murillo, Lord Byron, Milton, Juvenal, Virgilio, Tasso, Leopardi!

¡Allá van, los de las inmortales creaciones!

¡Oh! y de allá del Oriente, los fantásticos recuerdos de los muslínicos palacios de sultanas garridas pulsando con níveas y róseas manos la Guzla de nácares incrustada y cuerdas de oro, entonando con voz sólo comparable a la de las Uries, que en el excelso trono a Alá están, mil garridas canciones de amor!

¡Y cuan hermosos, el blando y armónico ondular de la música que por célicas manos, arrancada de la cítara, en las mezquitas do recitando, dulces versículos del Alcorán, proster- 
nados para mejor adorar a Alá, están los visires y valies!

Puesto no me entiendes, tenme por sabio, asómbrate y adórame, ¡oh! ¡Pueblo!

Pepita Gherra

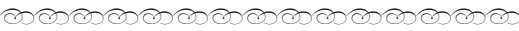

\section{A los compañeros}

Aclaración del editorial del núm. 2

Creemos de todo punto necesaria una pequeña aclaración respecto a nuestro editorial del número 2 de $L a$ Voz de la Mujer.

En efecto, grande muy grande fue la tormenta que el referido editorial produjo. Esto muy fuera de cuidado nos tiene, y muy al contrario nos felicitaríamos por ello si no fuera que entre los disgustados hay también algunos verdaderos compañeros que de todo corazón sentimos hayan dado tan mala interpretación a nuestra idea.

Por cartas que hemos recibido y por lo que a nuestros oídos llegó, hemos podido comprender que la principal, si no única, causa de tal disgusto, es el que nosotras nos hayamos dirigido en sentido general al redactar tal declaración.

Ahora bien: nosotras, al dirigirnos en sentido general, no lo hacíamos a todos los anarquistas y sí sólo A TODOs LOS ESCARABAJOS DE LA IDEA, es decir, a TODOS LOS FALSOS ANARQUISTAS.

Verdad es, y con franqueza lo declaramos, que hemos estado un tanto confusas en la redacción de tal escrito, error bien disculpable en verdad a nosotras, y esta confusión ha sido debida a la falta de espacio, porque no se crea que nosotras nos retractamos de lo que hemos dicho, no; la confusión está en no haber ampliado y explicado bien nuestra idea.

Atadas, hipócrita y solapadamente, hemos creído debíamos contestar y contestamos; pero no que hayamos atacado, no; fuimos atacadas primeramente y por ciertas gentes que llamándose anarquistas nos zahirieron a su sabor y manera.

Compañero hay que cree a pies juntos que no existen tales gentes $y$ que todos son amigos de la emancipación de la mujer. Nada más incierto.

Si como no disponemos de espacio dispusiésemos de él, insertaríamos tres cartas que conservamos de las muchas que hemos recibido referentes a este asunto, pero ya que no las tres, una sí publicaremos para que se vea que hay mal llamados anarquistas que nos tienen declarada una solapada y rastrera guerra, sin otra causa que la de ser mujeres y ser verdaderas anarquistas (creemos serlo). Dice la carta:

Compañeros de La Voz de la Mujer, Salud.

Recibí el Nº 2 del periódico, felicitándome por haber encontrado compañeras que tan directamente atacan a esos miserables cangrejos que se llaman anarquistas con la boca, pero nunca con sus hechos. Yo, por mi parte, lo he llevado al seno de algunos hogares donde ocurre lo que vosotras atacáis. Adelante, compañeras,

Juan Arroyo, Chivilcoy 
Aun cuando tenemos otra que es más clara y terminante, damos preferencia a ésta por ser menos extensa, y creemos es bastante lo que dice.

Esta aclaración la publicamos para hacer que los buenos compañeros desarruguen el ceño y vean que no es a ellos a quienes nos hemos dirigido.

En cuanto a los otros, a los falsos y tontos, nuestro deprecio y basta. Para ellos nuestro editorial de hoy, para los demás esta franca y espontánea declaración, con la cual creemos se desarrugarán los ceños y seremos lo que fuimos y somos: las rebeldes que luchan unidas contra el común enemigo, la burguesía. Salud, pues.

LA VOZ DE LA MUJER

\section{: \\ Histórico}

(Colaboración)

\section{EN EL CONFESIONARIO}

\section{El padre confesor y una niña de 15 años}

- Padre, aquí vengo a que me absolváis de mis pecados.

- ¿Conque habéis pecado, hija mía? (Qué bonita es.)

- Sí, padre.

- Bueno; contadme, contadme vuestras faltas.

- Padre... tengo vergüenza.

- No debéis tener vergüenza, hija mía, de un ministro de Dios; habéis pecado y por lo tanto estáis condenada al fuego eterno del infierno, y si queréis salvar vuestra alma debéis decírmelo todo.

- Padre, he perdido dos misas, porque estaba mi madre enferma.
- ¡Qué barbaridad! haber perdido dos misas, mas valdría estar quemándose vivo que estar aquí sintiendo estas infamias. ¡Perder dos misas!...

- Padre; mi madre estaba enferma, sin ninguno que la cuidase, y yo no podía abandonarla.

- Pero desgraciada, no sabéis que primero es el alma y después el cuerpo, pero continuad. (El padre confesor tiene los ojos encendidos.)

- Padre, además hace algunas noches que al acostarme...

- Ya veo que os falta el coraje, pero para ser más fácil la confesión os interrogaré. ¿Cuando os desnudáis no tocáis con vuestros dedos ciertas partes del cuerpo?

- Sí padre (Se pone colorada).

- ¿Y encontráis placer en hacer eso?

- Sí, padre...

- Y decidme, ¿en qué parte del cuerpo tocáis con vuestros dedos?

- ¡Padre!...

- Hija mía, me lo tenéis que contar todo si no no os doy la absolución. ¿Os tocáis acaso en el cuello?

- No, padre, más abajo.

- ¿En el seno tal vez?

- Más abajo padre.

- ¿En el vientre será?

- Un poco más abajo padre (Se pone roja de vergüenza).

- ¿Os tocáis por desgracia la...?

- Sí, padre. (La niña se pone a llorar.)

- ¿Cuántas veces habéis hecho eso? (Si viniera en mi celda.)

- No lo recuerdo padre.

- Procurad recordar.

- No lo recuerdo porque lo he hecho infinidad de veces.

- Y decidme. ¿Quién os ha enseñado a hacer eso? 
- Ud. padre.

- ¡Yo!

- Sí, padre; no os acordáis cuando yo tenía 10 años vine aquí a confesarme, y vos me habéis preguntado si yo no me ponía los dedos en... esa parte que vos sabéis, y yo os contesté que no sabía hacer eso, y además me habéis dicho que todas las niñas hacían eso, y que era muy bonito. Entonces a la noche quise probar, y sintiendo placer lo seguí haciendo.

- Desgraciada, estáis condenada por toda la eternidad. Decidme ¿no hacéis eso con vuestras compañeras?

- No, padre. (La niña no lo sabía, el cura le enseñó eso también.)

- ¿No tampoco le tocáis el... a los muchachos?

- No padre.

- Le habéis visto el... a algún hombre.

- ¿Padre, qué es eso que vos 1lamáis... que tienen los hombres?

- Hija mía, es una cosa con la cual se puede hacer la felicidad de cualquier persona.

- ¿Cómo se hace eso padre?

- Venid conmigo os enseñaré. (Ya no puedo más.)

- Os sigo padre.

\section{En la celda}

- Ahora veréis hija mía cómo se hace la felicidad de una persona.

- Vamos.

El padre confesor con los ojos encendidos y fuera de la órbita se desnuda, la niña se avergüenza al verlo como la madre lo echó al mundo; el padre confesor con la baba en la boca se abalanza sobre ella, la niña por ins- tinto de conservación abre la puerta y huye, y nunca jamás se presentó al confesionario ni tampoco va a la iglesia porque se ha convencido de que es una farsa que representan esos infames. (1)

Padres de familias que tenéis hijos, no los mandéis jamás a esos antros de ignorancia y depravación, no mandéis a vuestros hijos al confesionario porque esos infames buscarán de corromperlos y hacerlos servir de pasto para sus lúbricas pasiones.

Podría narrar muchísimos hechos para demostrar lo que digo, pero creo que vosotros ya lo sabéis, solamente me limitaré a contar un hecho que ha pasado recientemente en La Plata.

Una familia mandaba a sus dos hijas, niñas de cortísima edad, a la iglesia de San Ponciano, y el bandido de sotana un día las tomó y las llevó a una celda y allí las violó.

Las niñas se encontraban en un estado grave y se desesperaba de salvarlas, los padres dieron aviso a la policía; no sé si el cura ha sido arrestado.

¿Qué dice de esto la Voz de la Iglesia? ¿qué dice el clero? ¿qué dice la sociedad burguesa? Pues nada, como si nada hubiera pasado.

Padres de familia, alerta contra esos mercaderes de carne humana.

¿No veis que el confesionario es el cebo que ponen para atraer a las incautas y sacrificarlas en aras de sus apetitos carnales? Ellos las deshonran y como si

(1) Queréis una prueba de que es histórico el hecho que acabo de relatar:

Pues bien, el padre confesor vivía en la iglesia de la Piedad y la niña era yo.

Luisa Violeta 
no fuera suficiente, le añaden el desprecio y el insulto, ellos que con el cinismo que los caracteriza nos hablan de Dios, de perdón y de tantas otras farsas que ellos han inventado para cometer impunemente sus fechorías.

Padres de familia ¿no veis que sus instintos son más negros que el traje que visten? ¿no veis la máscara de la hipocresía que llevan? no os fiéis nunca de esos bandidos, ladrones y asesinos protegidos por sus hermanos la Autoridad y el Gobierno.

Y vosotras niñas si no queréis ser víctimas de esos asquerosos reptiles, no tratéis nunca con la gente que huele a sotana y evitad la ocasión, no yendo jamás a la iglesia.

Con que, así, niñas queridas, aler$t a$, porque os demuestran confianza y cariño, y es para que depositéis la vuestra en ellos y poder así engañaros y haceros víctimas más fácilmente.

Yo también he sido niña, y podría contaros algunas escenas más del confesionario y de la iglesia de que han sido víctimas mis compañeras de infancia, pero creo que tendréis suficiente con lo que acabo de relatar.

Queridas niñas, estudiad bien la cuestión social y os convenceréis que la Anarquía es la única idea verdadera de la emancipación proletaria, en donde desaparecerán todas las injusticias sociales y en donde empezará una nueva era de paz, armonía, libertad, progreso y amor.

Cuando os habréis convencido de esta verdad, lucharemos todas unidas para provocar la gran Revolución social, la cual barrerá clero, gobierno, autoridad, capitalismo, códigos, leyes, magistratura y toda esa falange de ato- rrantes que nada producen y de que todo disfrutan sobre nuestros sudores.

Niñas queridas, gritad conmigo: ¡Viva la Revolución social! ¡Viva la Anarquía!

Luisa Violeta

米米米米米米米米䊉米米米米

\section{A TI}

A ti ¡oh mujer querida, símbolo de ternura y de cariño! tú que en el mundo estás llamada desempeñar los más arduos problemas de la vida y no ejerces más que un papel secundario.

A ti hablo; a ti que siendo el juguete de tus padres cuando niña, el capricho de tu marido cuando mujer y a veces, que es lo peor de todo, el escarnio de los hombres.

El capricho de tus padres, éstos han tenido la desgracia de estar sumidos en la ignorancia que por mero egoísmo lucrativo o por engaño le entregan a un hombre a quien tu corazón no ama ni amará jamás y pensando hacer tu dicha labran tu propia desgracia, siendo el más grande sacrificio tuyo el entregar tu cuerpo al hombre a quien repudias hasta de tener con él el mínimo contacto; y no obstante, con todo cinismo le mientes un amor que sientes y una fidelidad que tal vez no cumples, mientras que otro que te amaba y tú correspondías, ha muerto para ti.

El capricho de tu marido si has tenido la desgracia de dar con un hipócrita que en vez de hacerte feliz inculcando en ti cuanto hay de bello y bueno, noble y elevado, compartiendo contigo sus momentos de dicha y 
de pesar, no hace de ti más que una esclava de servicio y compañera de lecho momentánea, hasta recibir tus favores y éstos si es que no los busca en brazos de otra y a ti te deja en el olvido, gastando en orgías con otras mujeres el tiempo y el dinero que sólo deberían ser para ti, lo primero para gozar y lo segundo para llenar las necesidades más apremiantes de la vida; y aun siendo así no te quejes, pues si lo haces con tu marido recibes indiferencias o palos y si te quejas a tus padres no hacen más que compadecerte y decirte que tengas paciencia, puesto que nada es duradero y una vez muertos todo se acabó. Mientras tanto tú sigues sufriendo hasta que cansada de pasar tantos vejámenes buscas en brazos de otro lo que tu propio marido te ha negado, y de esto resulta que por doquiera vayas eres la esposa adúltera y criminal, señalada de todos con el dedo, si es que has tenido la suerte de sustraerte a una muerte horrorosa.

Si es que por codicia al oro y a los placeres o por ignorancia tuya has creído a las mentiras de los hombres, éstos una vez saciado su apetito, te abandonan en brazos del destino, a veces sin techo ni abrigo, ni con qué poder aplacar el hambre. Tú al principio luchas con abnegación, luchas hasta con la miseria, pero cansada de sufrir te abandonas a otro paria, el cual tarde o temprano hace como el primero, quedando enteramente al azar de tu suerte, llegando de esta manera hasta la defraudación, vendiéndote al primer mercader de carne humana.

Es ya tiempo mujer querida, que caiga esa espesa venda de tus ojos. $\mathrm{Si}$ eres soltera, cultiva tu inteligencia, estudia cuanto puedas, trata de hacerte grande, igual al hombre, pues aunque mujer, eres su igual.

La naturaleza te brinda los mismos placeres y las mismas libertades y el alcanzarlas sólo de ti depende, despreciando como yo, leyes y capital, curas y religión, burguesas y burgueses, primero porque la ley sólo alcanza a los pobres y desgraciados; el capital para disfrutarlo el que lo roba y nosotros que todo lo producimos, estamos sumidos en la más espantosa miseria; los curas por ser falsarios y haraganes, que por medio de su refinada astucia contribuyen siempre a ser tu perdición por medio de la confesión; la religión porque embrutece a todo al que a ella cree, perdiendo un tiempo precioso que en cosas de más provecho podría usarse y quitándote dinero que tan necesario te sería para matarte el hambre y cubrir tus carnes; burguesas y burgueses por ser ellos los que te explotan y te tienen humillada.

Con que no olvides, querida mujer, que mientras existan leyes y capital, burgueses y burguesas, curas y religión, siempre serás desgraciada; no verás en torno tuyo más que miserias y desesperación y si cuanto yo te digo te convence, grita como yo: ¡Viva la Anarquía! ¡Mueran para siempre los vampiros de la sociedad!

Tulio el Burgués

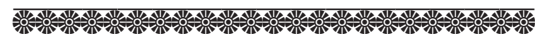

Compañeras de LA vOZ DE LA MUJER

Salud:

Buena acogida tuvo entre nosotros vuestro primer número. 
Es satisfactoria ver la clase llamada más débil de la sociedad, esta clase por todos encarnizada, abrazar los anchos pliegues de la bandera anarquista y por la vía revolucionaria proclamar altamente su emancipación.

¡Bravo compañeras! Así como la emancipación de los trabajadores ha de ser obra de los trabajadores mismos, obra de las mujeres mismas ha de ser su emancipación de ellas.

Razón tenéis en vuestro número dos cuando tratáis de cangrejos a ciertos tipos indignos de llamarse anarquistas; pues no son otra cosa que unos demagogos tiránicos, sin nociones de lo que es libertad y con las pretensiones de sabios; y saben difamar, insultar y prestar con su maquiavelismo más servicio a la burguesía que los mismos espías asalariados.

Ahora os felicitamos, queridas compañeras y no desmayéis continuar en la brecha, que si hay corazones empedernidos que tienen envidia a toda grande iniciativa, a todo ideal elevado hay corazones generosos que os tienen amor y cariño y estará siempre a vuestro lado para alentaros en la lucha y ayudaros a la medida de sus fuerzas.

Sí, compañeras y compañeros, ayudemos a la Voz de la Mujer que su emancipación ha de ser un gran factor para el buen éxito de la revolución social.

Adelante y ¡viva el Comunismo y la Anarquía!

POLVORÍn

\section{Algo sobre periódicos anarquistas}

Si fuera posible publicar diariamente un periódico anarquista por lo menos dentro de cada localidad, ¡cuánto más beneficioso sería para la propaganda y cuanto no adelantarían los ideales de emancipación social dentro de la masa popular! y está demás decir que mucho mejor sería si en vez de uno fuesen más.

Pero como nuestras fuerzas pecuniarias no son suficientes para cubrir los gastos de publicaciones diarias, tenemos que resignarnos a satisfacer nuestros anhelantes deseos cuando nuestras escasas fuerzas lo permitan, y tarde o temprano, se publican con la unión del pequeño óbolo aportado por "cada uno según sus fuerzas".

En Buenos Aires, no parecen estar unidos estos pequeños esfuerzos y lo prueba el que se escriben seis o siete periódicos anarquistas sin haber ninguno que salga semanal a pesar de sus correspondientes déficits.

Y no hay duda, en Buenos Aires se podría publicar un periódico con más cortos intervalos de un número a otro que la pausada aparición con que hoy todos aparecen, uniendo los esfuerzos de todos en uno o dos, y decimos dos, porque ya que nuestras compañeras han iniciado en Buenos Aires "La Voz de la Mujer" debemos de esforzarnos y ayudarle para que siga su circulación, pues es muy necesario su existencia.

\section{Dos Anarquistas}

Tenemos varias razones para no aceptar parte de lo que "Dos Anarquistas" dicen.

Hemos notado, sí, que hoy día la propaganda no responde a los esfuerzos que los compañeros hacen, pero 
no creemos que esto se remediase con un periódico Anarquista diario, ni dos, ni lo creemos conveniente.

Esperamos que alguien responderá a "Dos Anarquistas", no pudiéndolo hacer nosotros por falta de tiempo y espacio.

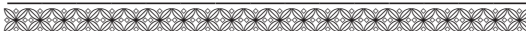

\section{LA ETERNA PLEBE}

El pueblo dormía.

-¡Esclavicémosle! -dijo el tirano; y cubrió su cuerpo de pesadas cadenas.

- ¡Fanaticémosle! -exclamó el sacerdote; e inundó su cerebro de sombras de dioses y vírgenes.

- ¡Oprimámosle! -gritaron los parásitos; e impusieron a su esfuerzo trabas, cubriéndole de leyes.

Y los nobles, los guerreros, los sacerdotes, los mercaderes, los parásitos, después de martirizar y explotar al pueblo, hicieron más: lo maldijeron por los siglos de los siglos.

Los nobles le azotaron el rostro con sus pergaminos, los guerreros con su espada, los sacerdotes con la cruz. Los parásitos lo apostrofaron y denigraron insultándolos.

De pronto, sobre el valle, pasó desoladora y terrible la tempestad.

El rayo brilló en el alto cielo, cual inmensa sierpe de llamas.

Gemidor, el viento anunció con la voz del exterminio los horrores de la terrible tempestad.

Crujieron los palacios y desplomáronse sus inmensas moles con formidable estrépito. Todo destruyó la tempestad. Derribó los templos, y pulverizó los palacios, y anonadó las fábricas y sepultó en sus escombros al pueblo.

Ninguno salvó. Obreros, artesanos, labradores, etc., etc., todos perecieron víctimas del furor de la formidable y horrorosa tempestad.

Sólo salvaron del exterminio los grandes, los poderosos, los cargados de oro.

Y los días pasaban, el sol con sus dorados rayos corrompió los cadáveres y recalcutó la tierra.

La atmósfera tornóse pestilente; aquello era insoportable.

Los grandes se morían de hambre, rodeados de oro.

Andaban mugrientos porque no sabían ni querían lavar sus ropas.

Los graneros vacíos o destruidos les eran inservibles; los campos, mustios y yermos, los espantaban; pronto la peste y el hambre los obligó a salir de sus alcáceres y a recoger los cadáveres para enterrarlos, a fin de librarse de las miasmas fétidas que despedían.

Después...

Después, los magníficos, los poderosos, los soberbios, los indomables, cultivaban la tierra, trabajaban la madera y el hierro, cultivaban las artes.

Habían tenido que hacerse pueblo para vivir.

Imitación de Carlos Christian.

Pepita Gherra

\section{* NOTA S***}

Hemos recibido la visita de:

El Oprimido, El Perseguido, La Luz, L'Avvenire, La Libre Iniciativa 
y el primer número de Caserío, con quien establecemos gustosas el canje. La dirección de este colega es: H.W. Haufman Casilla Correo N ${ }^{\circ} 1120$.

La Revolución Social es el título de un nuevo campeón comunista-anárquico, cuyo primer número recibimos. Su dirección M. Requera Casilla Correo $\mathrm{N}^{\circ} 15$.

Retribuimos saludo a ambos y establecemos canje.

$$
\begin{array}{cr}
* & * \\
* & * \\
\text { RAVACHOL }
\end{array}
$$

Se nos informa haberse formado con este título (en Chivilcoy) un nuevo grupo de propaganda.

Saludamos a los compañeros del grupo "Ravachol" y le ofrecemos para todo lo que podamos.

$$
\begin{array}{ll} 
& * \\
* & *
\end{array}
$$

Avisamos que hemos recibido 1 peso y 50 c. para las compañeras Ragaccini y Libertad.

Pueden esas compañeras avisar a dónde debemos enviárselo.

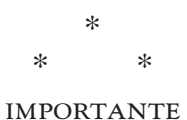

Avisamos a todos cuantos les mandamos "La Voz de la Mujer" que los que antes del próximo número no nos hayan avisado si lo reciben o no, les suspenderemos el envío.

Lo haremos así en vista de que enviamos muchos paquetes que ignoramos si llegan a su destino.

Avisamos también que siendo excesivo el número de pedidos que tenemos, tendremos que aumentar el número de ejemplares, y para que esto no obs- taculice la salida del periódico, pedimos a todos su óbolo.

La Redacción

\section{米料米米米米米米米米米米米米料}

\section{CORRESPONDENCIA}

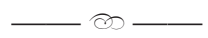

Avisamos a los que nos han reclamado suscripciones, que éstas no han llegado a nosotras.

Luisa Violeta - Publicamos y esperamos lo demás.

Anónimo - Como tu carta es un ídem no hemos podido responderte. Nos gusta tu crítica. ¿Quieres hacer una de cada número que salga?

Sabonarola ¿Quiere ser nostro corresponsal?

Buscaglia - Irá número próximo.

Grupo "La Chispa" - Mandamos como decís. ¿Indispensable publicar lista completa o hasta el total? recibimos 16 pesos y suma 16.70 .

Arroyo - Mandamos, como dices, avisa a medida vayas recibiendo.

C. Gino - ¿A dónde mandamos el resto de los 6 pesos?

Céytum Mar del Plata - Céytum del diablo ipor qué no escribes? ¡Salud!

"La Luz" - ¿No has recibido carta? ¿por qué no escribes? y ¿La Luz?

Miscosi - Recibimos las dos listas que suman 9 pesos.

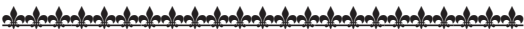

\section{SUSCRIPCIÓN}

\section{A FAVOR DE LA VOZ DE LA MUJER :*:}

Por conducto de "La Questione Sociale" Capital. 
Fumo sin estampillas $0.50, \mathrm{H}$. Veneno 0.20, F. Serrano 0.75, Carlos Bervoni 0.15, Un socio 0.05, Eugenio Deviotti 0.10, La verdad Desmiento 0.20, Schiassi Beniamino 0.20 , Un zio de la religión 0.20 , Uno de la idea 0.20, Gazzini Batista 0.10, Miserable 0,10, L. N. 0.20, F. Barrera 0.20, Augusto Masco 0.30, Un Gerente 1.00, A. F. 0.30, Bancalari 0.50, Un conscrito 0.20.

Grupo "Las decididas de Almagro"

Una que piensa libre 0.40 , Un capricho 0.20, María 0.10, R. M. 0.10, Carmen 0.20, ¿D? si 0.30, Isabel S. 0.20, Un cañón 0.25, M. A. 0.50, María 0.10, Carmen 0.20 , M. D. 0.20, Una que piensa libre 0.50 , Una anarquista 0.20 . Calvo:

Entregado a nosotras por el compañero

Reunión del $1^{\circ}$ de Febrero 1.40, Otra la misma noche 2.80, Baigornia 0.50, Nada 0.20 , Dos que quieren crisoles para fundir burgueses 2.00, Gino y Amelia Ciolli 0.10, Un candidato a burgués 0.10 , Dos compañeros 0.20, Gelona 0.30, Pepita Gerra (Mar del Plata) 0.30, I. M. R. Martínez (Mar del Plata) 0.20, Carmen Lareva 0.30, Un Anónimo 1.00, Un malfattore 0.90 , Robado a Antonio 0.10, Robados a M. 0.10.

\section{Barracas:}

Vitta 1.00, Dos amigos 1,00, La pólvora 1.50 , Sastre explotado 0.15.

Témperley:

¡Abajo los cambalacheros de la Anarquía! 5.00

\section{Montevideo:}

Messina Maestrini m/n argentina 0.40 .

Chivilcoy, por conducto de Orsini:

Ni Dios, ni patrón, ni marido 0.30, Un amor libre 0.30, Miscosi 0.40, Francio 0. 50, Lagrave 0.70, Segurbuorn 1.00, Uno que se paga en la verdadera moral 0.80 , Idem por conducto de Miscosi M. Martínez 1.00, Mesa 0.50, Segurbourn 1.00, Ondrio la B. 0.50, Uno que piensa bien 1.00, Uno que quiere el amor libre 1.00, Idem por conducto de J. Arroyo, recolectado en el grupo "Ravachol" Juan Arroyo 1.00, Los mandas no más 1.00, José Tocino 2.00, Un vasquito que le gusta la idea 1.00 , Por echar unos clavos 0.20, La señorita 0.50 , Pedro 0.25, Un amigo de las mujeres 0.50, Libertad y progreso 0.50, Para "La Voz de la Mujer" 0.50, Para la propaganda 1.00, Un amigo 0.30, Como quieras 0.20, Para los Oprimidos 0.50, Para la anarquía 0.50 .

La Madrid:

Grupo "La Chispa" 16.00 para "La Voz de la Mujer" y para "La Libre Iniciativa" 6.00 .

Por conducto de un compañero

Sta. M. Guerra 0.50, Sta. P. Guerra 0.50, Sta. Anita sin novio 0.30, Sta. Antonieta Cassociva 0.10, Sta. Piosetta Capriciosa 0.50, Sta. Libertad Oller 0.50.

La Plata, Sabe Nada 0.20, Eliseter Buscaglia 0.10 .

Total recibidos: $\quad 66.00$

GASTADOS

Por 1000 ejemplares de este número $\quad 30.00$

Para entregar a

"La Libre Iniciativa" $\quad 6.00$

Correo y otros $\quad 8.80$

Déficit anterior $\quad 16.00$

Total gastos $\quad 60.80$

Quedan para el próximo número $\quad 5.20$

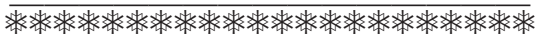

\section{LA SOCIEDAD FUTURA}

POR

$$
\text { JUAN GRAVE }
$$

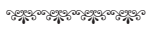

Advertimos a los compañeros que la Imprenta Elzeviriana de P. Tonini, Piedad 1200, está por editar la última obra de J. Grave: LA SOCIEDAD FUTURA. 
Como este libro es importante y voluminoso y la edición castellana de la Biblioteca de la Jurisprudencia, Filosofía e Historia de Madrid cuesta 8 pesos, dicha imprenta se compromete proporcionar a los estudiosos de ciencias sociales tan espléndido trabajo, de unas 350 páginas, por la suma de tres pesos $\mathrm{m} / \mathrm{n}$ en el término de un mes y medio.

Para facilitar su difusión, la casa editora ha resuelto también en este intermedio recoger suscriptores, los que obtendrán dicha obra por dos pesos $\mathrm{m} / \mathrm{n}$, debiendo éstos, para ser considerados como tales, remitir, contra recibo correspondiente, la mitad del importe $(\$ 1 \mathrm{~m} / \mathrm{n})$ anticipadamente al editor, y la otra mitad será abonada a la entrega de la obra.

Las adhesiones se reciben únicamente en la Imprenta Elzeviriana, Piedad 1200, Buenos Aires, personalmente o por carta. 



\section{LA VOZ DE LA MUJER}

$\begin{array}{ccc}\begin{array}{c}\text { Aparece cuando puede } \\ \text { y por suscripción voluntaria }\end{array} & \text { Periódico Comunista-Anárquico } & \begin{array}{c}\text { Dirección: A. BARCLA } \\ \text { Casilla Correo } 1277 \text { - Capital }\end{array}\end{array}$

\section{ACTUALIDAD \\ Cuadros Lúgubres}

Tristes, bien tristes son las noticias que día a día nos comunica el telégrafo.

¡Parece que un vértigo de sangre se haya apoderado de la vieja Europa!

¡Lucha, destrucción, hambre y ruina! He aquí el punto que de lejos se observa en los acontecimientos que todos los días leemos.

Madres sin hijos, hijos sin padre, hermanas que lloran sus hermanos, parientes que lloran la muerte o la inutilidad de los suyos, la miseria enseñoreándose por doquier.

Las fábricas sin obreros, los campos sin personal suficiente para el sembradío y la cosecha; el movimiento fabril e industrial paralizado, millares de hombres, mujeres y niños que a voz en grito exclaman ¡Pan y trabajo!

Tended vuestra vista por todas partes ¿qué veis?

Veréis allá en Cuba que los ingenios en que poco ha crecía la caña, el tabaco y otras plantas, se hallan hechos ruinas; los campos arrasados por la tea del incendio, sepulturas a cada instante, en las cuales yacen multitud de cadáveres; veréis aterrada la gente huir de los campos, en confuso tropel, escapando de las balas y de la miseria, multitud de cuerpos que caen pesadamente debido a las ambiciones de los unos y de los otros.

Veréis también aquella juventud española (?) que, obligada por la fuer- za, parte para los campos de Cuba a defender en nombre de la integridad de la patria y del honor de la bandera, los intereses de sus verdugos que se ven amenazados por la Revolución.

Y mientras ellos en los campos de Cuba, bajo aquel mortífero clima, luchan desesperadamente, sus verdugos siempre ávidos de dinero y deseosos siempre de verter sangre obrera, recargan con impuestos al ya oprimido pueblo, para obtener el dinero necesario para sostener esa guerra fratricida.

Veréis también la miseria implacable, terrible, amenazadora, invadir los tugurios del pobre proletario; los hijitos desnudos y con el rostro demacrado pidiendo con lastimera y angelical voz ¡pan! ¡mamá dame pan, que tengo mucha hambre! desgarrando de esta manera el corazón de las madres que ya lloran a sus esposos, hermanos o parientes, que hombres infames y de negros sentimientos, en nombre de una ley inicua, arrancan de sus hogares para que vayan a destrozarse en los campos de batalla.

¿Qué cuadros tan conmovedores!

Y si tendéis la vista hacia Oriente ¿qué veis?

La lucha desastrosa que se desarrolla en Turquía, entre musulmanes y cristianos.

Ciudades enteras destruidas; sus habitantes pasados a degüello; ancianos, jóvenes y niñas, violadas ora por la soldadesca, ora por la enemiga muchedumbre o inmoladas ferozmen- 
te en aras de sus rivalidades; el hambre y las enfermedades originadas por esa hecatombe sientan sus reales en toda la región de la Armenia.

Más de 20.000 personas entre hombres, mujeres y niños han caído regando con su sangre los fértiles campos de la Turquía.

Todo ¿por qué? Porque unos 1laman a esa divinidad todopoderosa, Dios, los otros le llaman Alá; porque los unos le rinden culto de una manera y los otros de otra; porque los unos creen que su religión es la mejor y los otros creen que es la de ellos. Y mientras tanto ambos bandos se despedazan mutuamente, esas falsas divinidades no dan señales de vida.

Si los hombres hubiesen comprendido que esas religiones no sirven más que para sumir más y más en la ignorancia a los pueblos, no se destrozarían entre sí de esa manera salvaje, en esa inhumana lucha que ellos tratan de alentar para que los pueblos no abran sus ojos y luchen, sí, ipero para reconquistar sus derechos que por la fuerza le han sido quitados!

¡Todo es llanto, miseria, destrucción y ruina!

Ved el África que está sufriendo las mismas consecuencias que la vieja Europa.

Los civilizadores italianos bajo pretexto de desarrollar las ciencias y las artes, devastan los campos, incendian las aldeas, y la sangre de los infelices soldados italianos, hijos del pueblo, y abisinios, riega los fértiles campos de la Abisinia; aquellos campos que antes estaban cubiertos de doradas mieses, donde los bueyes los atravesaban trabajándolos, se ven hoy, debido a la infame conducta de un Crispi, que no sabiendo cómo sostenerse en el poder alienta el patriotismo del pueblo italiano para que vaya a morir bajo los ardientes rayos del sol africano en defensa de mezquinas ambiciones.

1.500 soldados de una vez, 10.000 de otra, sin contar los de Dogali y Sahati, yacen sepultados en aquellos campos y cuando el pueblo cansado de desangrarse de tan cruel manera, organiza manifestaciones protestando contra esa inicua guerra, mandan los soldados, los hijos del pueblo, que carguen contra los proletarios, y un infame que se titula grande, un Umberto que vive de la sangre del pueblo, un miserable cretino que no sirve más que para autorizar impuestos onerosos, robos escandalosos, pega una solemne bofetada a 27 millones (no contamos la burguesía) de seres que a voz en grito piden el cese de esa cruenta guerra, diciendo en un arranque de orgullo sin límites, QUE PREFERIRÍA ABDICAR LA CORONA ANTES QUE ABANDONAR LA CAMPAÑA DE ÁFRICA.

¡Qué infamia!

Vosotras madres de familia no podéis comprender todo lo horroroso que es una guerra; no podéis, no, comprenderlo porque siempre habéis sido esclavas y no se os ha permitido instruiros, no se os ha dejado otra libertad que la de ir a embruteceros y prostituiros dentro de esos verdaderos focos de corrupción llamados malamente santuarios de devoción; es por eso queridas compañeras que estáis sirviendo, aunque ciegamente, de instrumentos a esa infame canalla de sotana que se aprovecha de vuestra ignorancia para arrancaros uno a 
uno los secretos que tenéis en lo más recóndito de vuestro pecho.

Vosotras que sufrís los dolores de engendro y del parto; vosotras que durante la lactancia y la dentición pasáis largas horas de insomnio y de desvelos; vosotras que ayudáis a vuestros compañeros a criar los hijos, no tenéis la inefable dicha de poderos acompañar del fruto de vuestras entrañas, porque una raza implacable apoderándose de lo que a todos nos pertenece, ha dictado leyes que nos privan de lo necesario a la vida, que nos arrancan a los hijos de nuestro lado cuando pueden sernos útiles, llevándolos al servicio militar, donde no reconoce más padre ni más madres ni otros parientes, que la infame ordenanza que los obliga a matar a sus padres, hermanos y amigos, si esto es necesario para conservar los privilegios que sus verdugos ven amenazados por el populacho. ¡Cuántos hay que en revueltas populares mataron a aquellas que tanto amaban y con quienes iban a unirse dentro de poco tiempo!

Cuando no los llevan al servicio, es porque ellos tratan de emigrar antes que vestir la librea del esclavo.

Si por casualidad acontece algún conflicto que provoque una guerra, entonces el pobre proletario, el hijo del pueblo marcha a defender el honor de la bandera.

Allá va, con el semblante pálido, descolorido, parece la muerte andando; se ríe, se... sí para que los suyos no se entristezcan; las madres quedan llorando en sus míseros hogares, los padres inclinan la cabeza pensando tal vez en la desgracia que cae sobre su familia por la marcha de un hijo adorado que piensa quizá no volver a ver más; allá en la funesta campaña en medio de azares y fatigas, el pobre soldado estará pensando en los que por él estarán llorando y en medio de los sinsabores que allí pasa, enviará quizá antes de entrar en combate, un cariñoso recuerdo o derramará amargas lágrimas de despedida.

¡Ah! ¡Qué horrible cuadro representa la guerra! piernas por aquí, brazos por allá, cuerpos sin cabeza, los cráneos destrozados, los ayes de los heridos, los ecos quejumbrosos de los moribundos... la sangre regando en abundancia los campos de batalla; y mientras tanto los infames gobernantes sentados en muelles butacas, dentro de espléndidas habitaciones, reciben con indiferencia los partes de la guerra.

¡Hasta extraño parece que en nuestra era de adelantos y de civilización, hayamos de presenciar esos horribles cuadros de destrucción y de miserias!

¡Compañeras! Estudiemos sin descanso, y una vez conocedoras del Comunismo Anárquico, luchemos fuertemente para conseguir implantarlo, pues él acabará para siempre con estos "Cuadros Lúgubres", haciéndonos iguales, o sea libres.

La Redacción

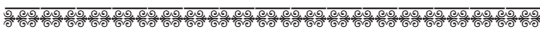

\section{CANCIÓN}

$$
\text { - }
$$

Yo soy un pobre obrero que cruza por el [mundo

como judío errante, seguido por el mal; jamás de los placeres libé la dulce copa; una brinda el hado con penas nada más. 
Se elevan a mi vista magníficos palacios, y sólo una cabaña yo tengo por mansión donde la higiene nunca llegó a mostrar [su influjo y adonde asoma apenas la clara luz del sol.

Preséntase a mi paso surtidos abundantes de telas vistosísimas que invitan a vestir, y yo en mi vestimenta tan sólo llevo

[harapos

manchados con la pringue que toco en $\mathrm{mi}$ [trajín.

Veo manjares ricos que el apetito excitan con su admirable aspecto y su fragante olor, y a mí de pan regado con lágrimas amargas apenas me alimenta la mísera ración.

Yo creo esas riquezas que veis por todas trabajo solamente para el ajeno bien, [partes; y sin embargo, veo que siempre soy mirado lo mismo que un leproso por el feroz

[burgués.

En todas partes sobran productos de la [industria que son (por excedentes), inútiles al fin, y a mí no me conceden mis sórdidos

[verdugos ni lo que me hace falta para poder vivir.

Yo soy un pobre esclavo que cruza por la [tierra como judío errante, sufriendo nada más; para curar mis penas espero solamente el triunfo de la ansiada Revolución Social.

Esther Buscaglia

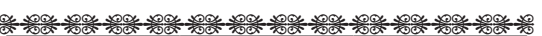

\section{NOSOTRAS A VOSOTRAS}

Odiamos a la autoridad porque aspiramos a ser personas humanas y no máquinas automáticas o dirigidas por la voluntad de "un otro", se llame autoridad, religión, o con cualquier otro nombre.

Aspiramos a demoler por todos los medios a nuestro alcance la actual sociedad, no porque odiemos, como se nos quiere hacer creer, a todo el género humano, no, lo que nosotras odiamos y combatiremos con todas nuestras fuerzas, es todo género de infamias.

Aspiramos a educarnos en la cotidiana lucha por la conquista de nuestros derechos.

Algunas de nosotras jamás hemos tomado una pluma, ni aun para poner nuestros nombres, y no obstante nos hemos decidido a poner nuestras fuerzas al servicio de la tan ansiada Revolución Social.

Queremos hacer comprender a nuestras compañeras que no somos tan débiles e inútiles cual creen o nos quieren hacer creer los que comercian con nuestros trabajos y nuestros cuerpos.

Queremos libertarnos, rompiendo, deshaciendo y destrozando, no sólo nuestras cadenas, sino también al verdugo que nos las ciñó.

Hemos resuelto arrojar el trapo con que a guisa de pañuelo enjugábamos nuestro llanto y empuñar la piqueta para destruir la imponente y dorada mansión del que estando repleto no quiere creer que haya hambrientos.

Ayer suplicábamos, rogábamos, mas hoy tomaremos lo que falta nos haga, cuando y en donde podamos tomarlo.

Las noches de largo y hambriento insomnio las sustituiremos por las hecatombes de sangre de canallas.

No tenemos Dios ni ley. 
El fruto de nuestros amores no tendrá patria, porque cuando ésta le quiera llamar, iremos nosotras a dar buena cuenta de los que de la patria viven.

Queremos extirpar del mundo todo lo podrido, lo asqueroso y, junto con él, el actual chiquero y la colmena para levantar una vez removida la tierra un nuevo edificio, pero sobre bases más sanas, más sólidas, más justas, más duraderas.

Estamos cansadas de la eterna farsa, queremos luz y no oscuridad, queremos derecho y no tantos deberes, queremos pan y no leyes.

Estamos hastiadas de mendigar, ya no queremos limosnas, asilos, hospitales ni iglesias.

A las asquerosísimas e hipocritonas damas de las diferentes sociedades, de las Vicentes y Pedros de Paul, o de Kooch, las despreciamos y les diremos que no queremos su caridad, hecha a expensas de lo que sus maridos robaron a nuestros compañeros.

Odiamos la caridad porque ella nos denigra, nos ultraja, y es un horrendo sarcasmo. ¡Caridad! ¿Qué es ello? El infamante mendrugo que dan o tiran aquellos a quienes les sobra, a los que les falta.

No, grandísimas... matronas; no, no queremos vuestro mendrugo, tomaremos lo que nos haga falta.

$\mathrm{Y}$ tened entendido que si se nos desprecia y odia, odiamos, si se nos persigue, nos vengaremos y si se nos mata, nos vengarán.

Ya no queremos iglesias porque ellas son causa de que se haya prostituido a nuestras hijas, corrompido nuestros hijos y sumido en la más crasa ignorancia y espantosa miseria a unos y otros.
Ya no iremos más a vuestros confesionarios señores y reverendos y Castro Rodríguez, no, no iremos más.

$$
\text { * } \quad *
$$

Y vosotras, infelices compañeras nuestras que os matáis todo un día para hacer una docena o dos de camisetas, por las cuales se os paga la veintésima parte de lo que luego ellos cobran, ¿creéis que eso es justo? Si reclamáis no os atenderán y lo que es más probable os despedirán, no os darán más trabajo, si os declaráis en huelga, la perderéis, y si la ganáis, no tardaréis en estar en peores condiciones, porque la evolución de los demás gremios hará nulo vuestro triunfo, no, no haréis nada si nos os rebeláis contra los ladrones.

Destruyendo es como se puede derrumbar el mundo de la explotación.

Imitad nuestro ejemplo. Rebeláos abierta y francamente, sin ambages, sin términos medios.

$$
\text { * } \quad *
$$

Y tú, niño infeliz e inocente, mártir indefenso de la sociedad actual, ¿por qué tiemblas y lloras? ¿por qué vas sin zapatos? ¿por qué tan andrajoso y aterido? ¡Ah! tienes un patrón que te maltrata... somos contigo, tú eres de los nuestros y en tu defensa estamos.

$$
\text { * }{ }^{*}
$$

Y tú, pobre madre ¿qué tienes, que tanto te desesperas, y tan profundos gemidos exhalas?

¡Ah! no tienes pan para tus tiernos hijos. Sí, lo comprendemos, 
están enfermos y no tienes con qué curarlos. ¡Ah! pobre madre, para ti no existen los adelantos de la ciencia, para ti no hay los eficaces remedios, ni sabios Doctores, tú no tienes dinero y por lo tanto para ti no hay nada; estás sola, completamente sola y aislada en el mundo. ¡Ah! ven, sí, ven tú también con nosotras y juntas lucharemos...

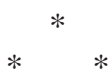

Y tú, ¡oh infeliz doncella que yaces sumida en el tenebroso recinto del prostíbulo! Cesa de llorar y desesperarte, no invoques, no, no invoques ya más a ese Dios que no existe, y por lo tanto no te oye; tu Dios es la sociedad, y ésa te señala con el enguantado dedo. Sí, ¿la ves? ¿allí detrás de aquella joven y pálida niña, aquella que es casi tan hermosa cual tú lo eras? pues bien, allí detrás están su padre y su hermano.

¡Sí, ya lo sé, pobre niña, lo sé, el padre fue amo del tuyo y el hermano fue quien te compró por cuatro monedas! sí, tu padre fue despedido, tu madre enferma y tus hermanitos agonizaban de hambre; sí, ya lo sé, no digas más...

¡Ven también con nosotras, ven pobre niña, ven y seremos uno más!

Tú también, mísero jornalero, que sin luz, sin amor, sin amigos, te encuentras triste y abatido en ese húmedo y estrecho calabozo... alza ya tu frente rugosa, ¿ves?, viene a verte tu ex amo, el mismo que te explotó a ti y a mil otros, lo ves, ha prosperado, viste el aristocrático yaquet, el blanco chaleco y calza fina y ajustada bota de charol, jah! lo ves, te señala con el dedo, se sonríe, pues bien, ése es el mismo que explotó tu trabajo, prostituyó tus hijas e hizo ser adúltera a tu compañera.

Levanta pues tu abatida frente, lejos de ti esas torpes preocupaciones que te anonadan, álzate y rompe tus cadenas.

¡Falange de oprimidos! ¡preparáos! el porvenir no lejano nos ofrece un espléndido panorama y en él los mil y mil goces que la igualdad social nos proporcionará.

¡Alzáos proletarios! y estallen vuestras iras con pujante e indómita explosión.

¡Desdichados, perseguidos, esclavos, hambrientos, todos en fin cuantos sufrís el yugo con que la ruin actual sociedad nos esclaviza; venid a nosotros y juntos formemos el formidable ejército de los descontentos!

¡Venid todos!, enarbolemos el rojo pendón Anarquista, y cual torrente asolador lancémonos al combate, al grito de:

¡Anarquía por doquier!

Pepita Gherra

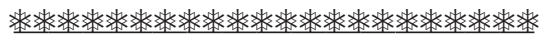

\section{La más grande de las conquistas}

La civilización en medio de los progresos que ha verificado, ha fabricado, conquista tras conquista, la idea del derecho, de la libertad.

Convencidos los hombres de que la tiranía tanto es obra de los que la sufren como de los que la imponen, los vemos moverse, agitarse, luchar contra la esclavitud de las leyes y del 
salario, del fanatismo y la ciencia, de las costumbres y las necesidades y más podría contenerse el curso de los más grandes ríos, que no el curso de esta fuete poderosa que dominan los sentimientos de dignidad y libertad que el hombre aspira a conquistar.

Pero en medio de esas agitaciones, de esos movimientos que amenazan destruir todo un pedestal de despotismos y esclavitudes que elevaron generaciones pasadas, falta un combatiente, el que con mayor seguridad acertaría el blanco, el que sin armas materiales llegaría a romper el cetro de cualquier tirano, el que daría ocasión al hombre a verificar la más esencial, la más gloriosa de sus conquistas, alcanzar su completa emancipación; falta la mujer.

¿Por qué, por qué - preguntará alguien- siendo un ser quizás "el más esclavo de todos", se mantiene en la ignorancia de sus derechos y de los derechos de los demás, vive en la indiferencia, olvida que ella es hija, esposa y madre de los que mueren combatiendo a los tiranos?

El canciller Maupeón, que ha negado rotundamente la aptitud del bello sexo para ciertas materias, diciendo que "las mujeres no entienden respecto a aquello más que los gansos", y aquel duque de Wurtemberg que contestó a los consejos que se ATREvió a darle su mujer sobre si debía o no empeñarse una guerra con la Suavia: "Señora, hemos tomado a Ud. para tener hijos y no para dar consejos", formaron perfecto diagnóstico de la dolencia que padecía la sociedad, señalando como consecuencia fatal que ese modo de pensar del hombre y ese vicioso modo de obrar, no podían dar al progreso, que como diría el doctor Letamendi, ser todo ello un germen de enfermedad y de muerte prematura, porque no hay que dudarlo, ni hay que objetar otras condiciones; sin la mujer libre, sin la mujer emancipada, el progreso general no será más que una suma de progresos individuales, hijos de penosa intuición.

¿Qué es lo que debiera hacer el hombre que trabaja, se agita, lucha, para alcanzar su emancipación? Conquistar ante todo a la mujer, que vive completamente separada de él, llamarla en todas sus relaciones de sociedad para que no viva en la ignorancia y en el parasitismo, sustraerla de la perniciosa compañía del jesuitismo, que se vale del poder que tiene ella sobre el hombre para domeñar a la sociedad, adormecer las generaciones y entorpecer la marcha del progreso y hacerla prácticamente igual y... entonces, en el seno de la confianza y la despreocupación, suavizados los rigores del período militante del mal obrar del hombre, rotas las cadenas de la servidumbre política, hermanados todos por el atributivo de derechos que emanan de una organización libre y perfecta, arreglada a las necesidades humanas, el hombre al alcanzar la libertad de la mujer, habría conquistado su emancipación, habría puesto freno a la tiránica brutalidad del déspota y habría, pues, derrocado todas las esclavitudes.

No hay que dudarlo; la más grande de las conquistas del hombre es educar y emancipar a la mujer.

Soledad Gustavo 


\section{LA MUJER CAIIDA}

Jamás ultrajéis a la mujer caída.

Cuando pasa por mi lado no puedo menos que llevar la mano a mi pecho y, haciéndome a un lado, admirarla: ella es la mártir de la sociedad.

¡Pobre mujer!

Yo me la imagino niña aún, allá en la modesta pero limpia cunita, asomar por entre los lienzos de la misma, su sonrosada $\mathrm{y}$ angelical carita.

A su lado su joven y tierna madre, que cariñosa y complaciente, vela, llena de amor, por aquel botón de rosa, por aquella primera manifestación de sus amores.

¡Cuán bellas ambas!

Pasaron años. La veía de niña, contemplo ya una joven y esbelta mujer.

La madre ya no está a su lado.

Está sola.

No obstante a su lado, a su alrededor todo le sonríe, todo la halaga y atrae, y allá en lontananza hay algo que la llama, con voz dulce y misteriosa.

¡Es el amor! Es la voz de la naturaleza que la llama, es la ley de afinidad, que la atrae y la incita a gustar de la copa del amor!

Más tarde fue madre. ¡Cuán bello es serlo! ¡qué de inefables placeres! ¡qué de misteriosos encantos hay en ellos!

Pero ¡ay! sólo encontró el desprecio y escarnio.

¡La sociedad lanzó contra ella un fulminante anatema y contra su hijo una feroz maledicencia!

¡Y ella fue la sin honor y él el bastardo!

(Continuará)

\section{1 * 18 DE MARZO * 1896}

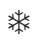

Para conmemorar esta fecha, que recuerda una gran epopeya en los anales de la historia del proletariado, los compañeros resolvieron celebrar una reunión en el local de la sociedad "San Martín”, Rodríguez Peña 334.

En efecto, el 18 del corriente tuvo lugar la anunciada conmemoración de la Comunne de París.

La concurrencia era numerosa; los discursos, a pesar de ser improvisados y de ser pronunciados por nuestros compañeros, los cuales no han tenido más estudio ni más universidad que el taller, encerraban una lógica profunda, esa filosofía popular que la burguesía, encenegada en el vicio y dominada por la ambición siempre creciente de las riquezas, no ha llegado aún a comprender y contra la cual se han de estrellar todos los esfuerzos que hagan para sofocarla.

El entusiasmo que allí reinó es indescriptible, pero llegó al colmo cuando una joven compañera subió sobre el banco que servía de tribuna y con un elegante y sencillo análisis demostró a los trabajadores que era necesaria una pronta transformación, aconsejando también a las mujeres que se rebelen contra el yugo matrimonial y contra la burguesía, que no ha creído ver en la mujer más que una máquina de placer, a la que se la hace mover en muchas ocasiones con un resorte llamado oro.

Desearíamos que todas nuestras compañeras siguieran el ejemplo de esta joven que, dejando a un lado preocupaciones sociales, se presen- 
ta ante un público aconsejando a las mujeres que luchen ardientemente por su libertad, ayudando de esta manera a los compañeros a acelerar el día tan deseado y por el que siempre luchamos: el día en que la Revolución Social será un hecho.

La Voz de la Mujer

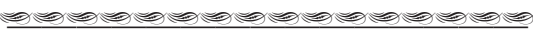

\section{Sin comentarios}

Una nueva arbitrariedad viene a aumentar el número ya crecido de nuestros mártires; una vez más los instintos salvajes de las autoridades francesas se han revelado con un acto de una refinada infamia, digna de los tiempos memorables de la Inquisición. Niza $1^{\circ}$ de febrero de 1896.

Nuestro apreciable compañero José Crotto de Alessandría (Italia) llegó a Niza el 3 de enero después de haber caminado a pie desde San Remo a Niza(1) sin comer. Llegado a este punto entró a una panadería en la cual pidió por limosna un pedazo de pan. ¡Ya veis, como una limosna, después de estar cansado de producir!; la dueña del negocio se lo negó, diciéndole que es un atorrante y que vaya a trabajar si quiere comer; pues bien, él no conforme con haberlo pedido y viendo que se lo negaban, se volvió sobre sus pasos, tomó un pan y echó a correr, comiéndolo; la dueña, que observó esto, empezó a gritar como un desesperado: ata-

(1) De San Remo a Niza habrá como 48 horas de camino. chez an voleur... atachez an voleur... atajen al ladrón... atajen al ladrón...

Ahí estaban dos esbirros, que siempre se hallan alerta para estas cosas, se le pusieron al frente, cual si fueran tigres que se lanzan sobre sus presas, le colocaron las esposas, apretándole las muñecas con una extraordinaria fuerza; como sentía el muchacho que las esposas puestas de ese modo le lastimaban de un modo atroz, gritó: ¡infames y miserables burgueses!; en esto una multitud gritó, dale... dale que es un anarquista. Aquella infame chusma alentó de esa manera un poco más los instintos salvajes de los esbirros, que redoblaron los martirios, apretando más las esposas.

Nuestro compañero, joven imberbe, pues apenas cuenta 16 años de edad, en el extremo de sus dolores, se puso a gritar fuertemente, ${ }_{i}$ Muera la Burguesía! ¡Viva la Anarquía! Estos gritos lanzados en medio de la desesperación que le causaban los dolores, le valió un nuevo apretón de las esposas. ¡Pobre mártir! ¡Cuando lo llevaron delante del tribunal, maniatado como un feroz criminal, se le veían las muñecas rotas, por la opresión de las esposas!

En el tribunal de justicia le preguntan:

- ¿Es Ud. anarquista?

- Hasta la muerte.

¿Sabéis qué pena le han puesto a nuestro compañero?

Pues la condena fue de tres meses de prisión.

La sentencia fue oída con mucha calma y no respondió más que las siguientes palabras:

Miserable población de Niza, llevo de vosotros un eterno recuerdo, pero 
no olvidéis que soy anarquista, piamontés y paisano de Santo Caserio. Esther E. Buscaglia

Hasta aquí la carta.

Ahora, madres de familia, decidnos; ¿de qué os vale haber trabajado tantísimos años para criar vuestros hijos, si esa miserable canalla os los encierra en viles prisiones, u os los envía a morir en los campos de Cuba o la Abisinia?

Estudiad, mujeres, y ayudadnos a nosotras en esta lucha emprendida contra la burguesía y las preocupaciones sociales.

Cuantas más seamos, más pronto venceremos.

Luchemos, porque en la lucha está nuestra vida, con la inacción demostramos nuestra muerte.

Luchemos, pues. "La Voz de la Mujer"

\section{N}

El 22 del mes próximo pasado ha fallecido en el Hospital Inglés de Montevideo nuestro apreciable compañero Pedro Fernández.

Dicho compañero había organizado una comparsa titulada "Proletarios y Burgueses". Recorriendo la calle Guaraní el Martes de Carnaval, cayó de uno de los carros en que iba la comparsa, teniendo la desgracia de ser apretado por uno de ellos.

La idea anárquica perdió en Montevideo uno de sus ardientes defensores, mas ¡no importa! otros ocuparán su lugar.

\section{* \\ $* \quad *$}

Deseando hacer una alegoría, con el título de todos los periódicos antiguos y actuales, que defiendan y hayan defendido la idea anárquica, para sacar copias fotográficas, se ruega a todos los grupos, Redacción y compañeros, remitan un ejemplar de cada periódico a G. R. a la dirección de "La Voz de la Mujer" A. Barcla, Casilla de Correo 1277 B. Aires.

Se ruega la reproducción de este suelto a la prensa Anárquica de Europa y América.

$$
\text { * } *
$$

Leemos en "La Nación” del 18 del presente:

...El Dr. Oliva se convierte en abogado de "los patrones", contra los "peones matriculados".

Estos individuos, dice, "no se pertenecen", "no pueden abandonar el servicio por su propia voluntad".

¿Sabe el lector lo que le pasa a un conchabado que abandona su patrón? El juez Oliva nos lo explica: "cae bajo la acción de la policía, que lo busca y lo entrega a su patrón, obligándolo a servir".

Todo el texto del documento que nos ocupa -el telegrama que va más abajo del juez nombrado al ministro de culto- respira el más profundo desprecio hacia esa casta de siervos que la ley de conchabos ha creado en la sociedad tucumana. Es imposible pedir un olvido más absoluto de los respetos humanos... ¡qué respetos! -de los sentimientos de conmiseración que inspira el último hombre cuando se lo ve ultrajado en su dignidad de tal. 
Si el juez Oliva ha querido hacerse él mismo esclavo de la ley para apretar la cadena a los conchabados, podía haber salvado siquiera su protesta de hombre libre. No lo ha intentado, en su afán por defender los intereses de los dueños de ingenios y librarlos de que sus peones los "estafen".

Ya saben los peones tucumanos lo que pueden esperar de una justicia que de tal suerte vocifera sus creencias.

Digamos aquí, para concluir, que los agitadores del movimiento obrero, que bregan por la jornada de ocho horas, piden verdaderas gollerías, al lado de la suerte que cabe al infeliz jornalero de Tucumán, aherrojado por la ley y vilipendiado por los jueces.

¡Venga la corte suprema cuanto antes y suprima tanta vergüenza!

Los comentarios dejamos que los hagan nuestros lectores.

$$
*^{*} *
$$

Tenemos a disposición de los compañeros los folletos:

"La Religión y la Cuestión Social", "La Anarquía”, "El Estado", "Cómo nos Diezman”, y algunos otros.

$$
\text { * } *
$$

Periódicos recibidos: "La Questione Sociale", "El Oprimido", "El Perseguido", "El Corsario", "Les Temps Nouveaux", "La Débàcle Sociale", "La Anarquía...", "El Carpintero", "El Tipógrafo", "La Luz", "La Revolución Social".

También los nuevos colegas : "La Expansión Individual..." y "Ni Dios ni Amo...", les saludamos y deseamos larga vida.

$$
\text { * }{ }^{*}
$$

Recibimos y publicamos:

La Plata, 19 de febrero.

Compañeras de "La Voz de la Mujer":

A las muchas plagas sociales que abruman a las desgraciadas obreras de esta ciudad, debemos agregar una más, los Fray-Liberales. La burguesía platense ha dado el grito de jalerta! en contra del oscurantismo clerical, disponiéndose a combatir como siempre los efectos, dejando intactas las causas; dicen les han de quitar su apoyo moral y material a la Religión, llevando a bautizar sus hijos, a alguno que otro casamiento y unas docenas de funerales por el alma de sus amigos o pariente fallecidos, y los frailes, como siempre, sonríen al considerar la eficacia de tales procedimientos.

$$
\text { * } *
$$

El administrador del insuperable Lombroso, el imbécil Juan Ferrari, acaba de darnos una muestra de su colosal entendimiento con los inimitables razonamientos que en carta publicada el 23 de Enero p. p. y dirigida al Presidente del Club Liberal nos obsequia. Leed la muestra. Dice:

"El obrero tiene derecho a formar parte de la nueva adormidera, pero en cambio no lo tiene a su completa emancipación; por consiguiente desprecio las teorías de Kropotkine y Recius."

Ahora digo yo: cualquier Ferrari más o menos Juan, tiene derecho a asirse de los faldones de la levita de cualquier presidente para aspirar a la bazofia de cualquier club. 
Juancito, desde ayer y de más antes aún, te conocíamos como un mistificador.

Hasta otra, compañeras.

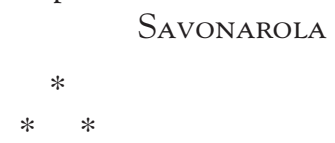

A pesar del aviso publicado en nuestro número anterior y el cual, de paso sea dicho, publicamos creyendo hacer un bien a la propaganda, pues como nosotras habíamos consultado con varios compañeros, los cuales eran de opinión de que para publicar la obra "La Sociedad Futura" de J. Grave son necesarios 1000 a 1300 \$ y creyendo que para recolectar esto sería necesario trabajar durante un período de tiempo más o menos largo, creíamos que pudiendo los compañeros adquirirla dentro de pocos días, no dejaría de serles beneficiosa.

Mas no obstante esto, los compañeros del grupo "Los Rebeldes" de La Plata se hallan completamente decididos a llevar a cabo su iniciativa de publicar dicha obra para cuyo efecto la está traduciendo un compañero.

Sería de desear que los compañeros coadyuvasen con toda disposición a esa iniciativa, para robustecer la propaganda con una obra de tanta valía. Nos adherimos a la iniciativa de nuestros compañeros, abriendo una lista de suscripción a su favor.

\section{CORRESPONDENCIA}

Savonarola: Habiendo terminado por nuestra parte las diferencias oca- sionadas por nuestro editorial del $\mathrm{N}$. 2 creemos conveniente no publicar la tuya.

No obstante esperamos ayudes lo que puedas para poder llevar adelante nuestra lucha y hacer que el grito de guerra lanzado a esta asquerosa sociedad repercuta en todos los ámbitos de la tierra.

El Corsario Coruña. Mandad las obras pedidas por Félix Méndez a la dirección que ya obra en vuestro poder. Mandad, si podéis, 2 ejemplares más del canje a nuestra dirección.

Idea Libre: Madrid. Lo mismo os decimos. Mandad canje.

Revolución Social. Oprimido. L'Avvenire: Mandad si es que os sea posible 10 ejemplares de cada número. Questione Sociale, mandad 5 en vez de 2. ¿Os es posible?

J. Molina y Vedia. Belgrano: Está bien. Luchemos, lo demás es secundario.

J. Cabello. Lobos: Es muy flojito. Si tiene algo mejor...

(Céytum) M. del Plata: ¿Bajas o subo?

M. Gogo. Idem. ¿Recibes "La Voz"?

Luisa Violeta. Capital: Y... ¿en qué quedamos? ¿Viene o no tu colaboración?

H. A. Capital: El de los "geniecillos” desea saber qué te pasó.

F. M. García. Idem: ¿Por qué no contestas? A ti ya te contestaron.

J. Arroyo. Chivilcoy: Extrañamos no hayas escrito.

"Oprimido" Luján: Tenemos 1,00 $\$$ para ti. ¿Entregamos a alguien por aquí? 


\section{SUSCRIPCIÓN}

\section{A FAVOR DE LA VOZ DE LA MUJER

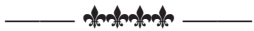

\section{Capital}

Un pintor sin pinturas 0.50 , Uno que expropió 15 \$ a un burgués 0.50, Un amante de la libertad de la mujer 0.50 , Montaña 0.80, $2^{\circ}$ Titta 0.30, Saftio 0.20, Papel 0.15, Otro 0.20.

Por conducto de "CASERIO"

Augusto Marre 0.30, Revolución 1.00, La compañera del Tigre de abajo los sauces 0.50, Olvidados 0.20, Prostituta 0.20, Corazón de León 0.40, Natividad Juanto 0.50, Uno que desea hacer salchichas de carne burguesa 0.10, Martínez Campos enfurecido 0.20 , Uno que busca compañera 0.20, Lamarmora 0.20, Motrreau 0.50, "Destrucción" 0.20, Un anarquista que quiere una compañera ídem 0.10 , Un Tiebolo y un Cerote 2.00, Manuel Costas 0.50, Un mozo de cuartel 0.50.

Por conducto de "El Perseguido"

Un explotado 0.20, Sobrante de un café 0.15 , Uno que los hace y no los cobra 1.00, Cinco Galleteados 3.50, Decoud 0.25, Viva Luisa Michel 0.25, Un litógrafo explotado 0.50, Un grupo de miserables 1.20 .

Rosario:

Una que no precisa curas ni jueces para casarse cuando lo tenga por conveniente 0.20 , Otro que desea ver colgados a todos los curas y jueces, 0.20 , Veneno a los burgueses 0.10, A Ruescas 0.50.
Mar del Plata:

Viva Salvador 0.20.

Tolosa:

Un hojalatero 0.20 .

San Isidro:

Hacha y veneno 0.40. Vizconde Bragelone 0.40 , Serpiente para devorar burgueses 0.40 , Media botella 0.40 .

Montevideo:

Messina Maestrini 1.00.

Barracas:

Una librería 9.25, Satanás contra todo lo existente y con su capital 0.30, Una gallega 1.00, Sobrante de copas 1.60.

Recibido a última hora, recolectado en "La Matadora"

San Pedro 0.10, El ñato 0.10, El Senegal 0.10, Recuerdo a Pepita Guerra 0.10, Un clérigo 0.10 , Un rayo me parta 0.10 , Yo solo 0.20, Yo recién 0.20, Yo mismo 0.10, Un ciego 0.20, Espejo 0.10, Un curiana 0.10, Finesterre 0.50. Resto de una convidada 1.00

Por conducto de "La Questione Sociale": Un pelotario 0.10, Una compañera 0.50, Fumo sin estampilla 0.30, F. N. La Plata 1.00 .

RESUMEN

Recolectado 29.85

Sobrante del $\mathrm{N}^{\circ} 3$

5.20

$$
\text { Total } \quad 35.05
$$

GASTADO

Por 1.000 ejemplares de este número, expedición, papel y otros 39.95

Déficit $\quad 4.90$ 



\section{LA VOZ DE LA MUJER}

Aparece cuando puede y por suscripción voluntaria
Periódico Comunista-Anárquico
Dirección: A. BARCLA

Casilla Correo 1277 - Capital

\section{A los Compañeros y COMPaÑERAS -}

Al hacernos cargo de la Redacción y Administración del periódico, no ignoramos las responsabilidades que pesan sobre nosotras.

No obstante seguiremos la huella de la antigua Redacción, es decir lucharemos sin descanso contra la actual sociedad burguesa; combatiremos sin tregua todos los prejuicios y preocupaciones que en la niñez nos inculcaron hombres estúpidos, mujeres fanáticas y otros miserables que ponen su pluma a disposición de la canalla, por un puñado de degradante oro que depositan en sus manos.

Siendo grande la preocupación que todavía existe en la humanidad con respecto a la mujer, debiendo destruir los prejuicios y preocupaciones que todavía la ciegan, la nueva Redacción ha creído conveniente aumentar el formato y el tiraje del periódico para hacer más extensivas nuestras ideas entre los escarnecidos y siempre vilipendiados obreros y obreras.

Compañeros y compañeras: La propaganda entre las mujeres está haciendo rápidos progresos; multitud de jóvenes empiezan a descorrer el tupido velo que tenían en sus ojos y vienen a nuestro campo a defender su libertad, su derecho a la vida, seguras de que luchando por ellas, luchan por sus compañeros e hijos.
¡A la obra, pues! La solidaridad es uno de los más bellos principios del Comunismo Anárquico: ésa es la que os pedimos, seguras de que nos seguiréis apoyando todo lo que os sea posible para mantener incólume la lucha sostenida contra los miserables que se obstinan en defender los salvajes instintos de la fiera sedienta de sangre llamada burguesía y de los canallas representantes de la tiranía.

Os saluda al grito de

¡Viva el Amor Libre!

¡Viva la Revolución Social!

¡Viva la Anarquía!

La Redacción

\section{A las jóvenes proletarias}

POR ANDORINHA

A los 18 años aún no habéis despertado al clamoreo de los secretos de la vida y cuán diferente os resultará el sueño de la infancia, realizado en la edad apellidada de la inocencia. A esa edad, la vida para vosotras es un sueño efectuado en el lecho de halagüeñas ilusiones que consigo trae la juventud. Vuestro ideal está lleno de encantos; vivís envueltas en la dulce esperanza; vuestros corazones extasíanse al pensar en futuras dichas.

Mas, ¡ah! todo cuanto idealizasteis lo hicisteis en vano, porque el camino 
de la vida es escabroso, a pesar de los impulsos de vuestra alma. A esa edad vuestra mente se halla sumergida en el profundo océano de la esperanza.

Os juzgáis felices ipobrecitas! mas no divisáis a lo lejos, entre opacas luces, surgir, envuelto en negro manto, el espectro horroroso del hambre que sobre vuestros hombros viene a descargar su pálida y demacrada mano. No veis los abismos que se abren a vuestros pies, puesto que vuestros ojos aún no están del todo abiertos para contemplar al mundo.

Sois como la flor, que nacida entre lodo y regada con aguas pútridas, al querer abrirse caénle los pétalos por la simple razón de entre el lodo haber nacido. También a vosotras, a pesar de todas vuestras ilusiones, la podredumbre os tiene rodeadas, y más tarde si no tenéis una fuerza de voluntad superior a la física que poseéis, os lanzará en las garras del lupanar. Y aunque hayáis trabajado hasta gastar vuestras fuerzas, estáis condenadas a morir de anemia en miserable jergón.

Las privaciones y el hambre, aunque jóvenes y bellas como estrellas resplandecientes de clara luna, en vuestro rostro, en vuestra angélica frente han de fotografiar los vestigios de un doloroso y constante martirio.

Vuestra vida es un suplicio llegando a veces hasta a haceros maldecir el vientre materno que os abrigó y los pechos que os amamantaron.

¿Y todo por qué?

Porque creeréis que los bellos sueños que un día os hicisteis se disiparon y que tanto los vuestros, como vosotras mismas, estáis rodeadas de iniquidades.
¡Pobres florecillas! Sin amparo y sin amor, vivís entre almas inhumanas, entre millares de buitres, que constituyen la actual sociedad. Vivís entre asquerosos reptiles, parásitos tiranos, entre hombres sin sentimientos, sin dignidad, sin pudor; entre una raza maldita, azote de la humanidad, escoria inmunda de la raza humana, que se alimenta con vuestras carnes, que goza con vuestras lágrimas y que acumula fabulosas fortunas con las gotas de sudor que vosotras derramáis. Habéis de vivir entre seres que son el sustentáculo de todas las infamias pasadas y presentes; que hicieron sucumbir a los vuestros bajo el peso abominable de la servidumbre.

Vosotras, lindas muchachas, pasáis lo mejor de vuestra vida en hilar, en tejer, en coser las preciosas sedas que ellos han de regalar a sus amantes, a sus mujeres y a sus hijas, para que lujuriosas soires sean la admiración de los concurrentes, al paso que vuestro flaco cuerpo debilítase más cada día, cada instante, sin que una lágrima salte a los ojos de aquéllos, ni una palabra de conmiseración pronuncien sus labios.

Vuestra vida, queridas, es así y no como la imaginábais; tiene los horrores que os describo y no los encantos que os habías imaginado. Si no queréis creerme, observad, haced comparaciones más desapasionadamente, y después convendréis que de mi lado se halla la razón. Sentiréis entonces la necesidad de saber el origen de tanta desigualdad entre los hombres y querréis saber, estudiar, analizar.

Para esto saber, habréis de recurrir necesariamente a la literatura anarquista. Después sentiréis en vuestras venas hervir la sangre con ardor y 
os reconoceréis con fuerzas suficientes para la lucha, comprenderéis que no hay fuerza mayor que la razón, ni nada en esta sociedad que no irrite los ánimos. Sentiréis la necesidad de poner término a todas las crueldades y a todas las desigualdades de clase; sentiréis el deseo de romper lo que nos oprime y de efectuar aquella felicidad que habíais soñado.

\section{¡Madres, educad bien a vuestros hijos!}

Sí, educadlos bien si queréis que sean hombres libres, de nobles sentimientos; para que luchen para obtener su completa libertad y no tengan que luchar por la existencia.

Pero debéis darle una educación sana y no la llamada educación o moral burguesa, porque la moral burguesa es una moral corrompida y falsa, y además es la que contribuye a tener sujetos a vuestros hijos a la cadena de la esclavitud.

No debéis enseñarles nunca la desigualdad de clases; enseñadles que somos hijos de la naturaleza, que todos venimos al mundo con los mismos privilegios, es decir que todos tenemos derecho a gozar de lo que la Madre Naturaleza nos brinda.

No debéis enseñarles a conocer la ambición o la codicia, enseñadles a despreciar el dinero, hacedles comprender que el dinero es la causa principal de todos los males que afligen a la sociedad: enseñadles que el dinero es la corrupción del Universo; enseñadles que el dinero es el que apaga en el hombre y la mujer todo senti- miento humanitario hacia sus semejantes, enseñadles que por ese vil metal se cometen toda clase de infamias y bajezas, que por ese asqueroso dinero se vende al padre, a la madre, al amigo y al hermano; que por el dinero los trabajadores se ven convertidos en animales de carga y en máquinas automáticas que se mueven a impulso de los que las dirigen y, en fin, enseñadles que por el maldito dinero sufrimos hambre, miseria y toda clase de privaciones.

No les enseñéis a creer en Dios; enseñadles que la religión es la atrofia de la mente, tanto de los hombres como de las mujeres y por lo tanto es la que impide el desarrollo del progreso; demostradles que la religión es contraria a las leyes naturales, que ella es el símbolo de la ignorancia y de la depravación, y, por fin, que la religión es una farsa que han inventado para que no viéramos más allá de nuestra narices y para que nos entreguemos atados de pies y manos, cual mansos corderos, a nuestros explotadores y tiranos.

No les inculquéis jamás los sentimientos de la patria; hacedles comprender que la naturaleza no hizo frontera y que por tanto todos somos hermanos; enseñadles que no tiene razón de ser el odio que profesan entre sí los seres racionales que habitan el planeta Tierra; no porque uno haya nacido en Oriente y otros en Occidente se van a odiar los unos a los otros, pues esas líneas que denotan la separación de un país del otro y a las que se dio en llamar fronteras, han sido trazadas por nuestros explotadores y verdugos para que confundiéramos a nuestros enemigos, tomando como tales a los que hubieran nacido al otro 
lado de nuestra frontera; enseñadles que para el hombre libre no debe existir frontera, en fin enseñadles que la patria es el símbolo de la explotación del hombre por el hombre, o como decía el compañero Spies "La patria es el último refugio de los malvados".

No le enseñéis a rebajarse, ni a humillarse, y menos someterse a la voluntad de otro, porque desde el momento que todos tenemos los mismos derechos, ninguno puede considerarse superior a otros: porque desde el momento que todos somos unos o sea iguales, cada uno es libre de su voluntad y por tanto es libre de hacer lo que él crea más conveniente.

Enseñadles a despreciar y a no acatar la AUTORIDAD de ningún individuo; sea ésta con cualquier nombre o bajo cualquier forma que se presente, porque donde hay una autoridad, donde haya uno o más individuos que ejerzan dominio o mando, tiene forzosamente que haber esclavos y donde reina la esclavitud no puede haber libertad.

Por último enseñadles que debemos ser libres, como libres son los animales que en el mundo habitan. Las aves revolotean incesantemente en el espacio infinito, las fieras establecen su residencia en los bosques y madreselvas, los peces recorren libremente su camino en las profundidades del mar.

Ellos no tienen raciocinio, pero tienen instinto de conservación y libertad; no conocen las ciencias, pero tienen aptitudes para construir sus nidos y guaridas; no tienen moral, educación, en fin, carecen de esas cualidades que constituyen la superioridad de los animales racionales.
Nosotros tenemos raciocinio, conocemos las ciencias (aunque no sea más que de nombre, porque en realidad...), hablamos de educación y de moral, pero en cambio no tenemos libertad, estamos divididos en dos clases completamente antagónicas y nos destrozamos (cosa que no hacen entre sí los animales de una misma especie) peor que las fieras; nos martirizamos los unos a los otros, en fin, que a pesar de tener uso de razón nos colocamos nosotros mismos en una situación peor que la de los mismos animales a quienes damos el nombre de fieras ( $i$ ?).

Ahora bien: si vosotras joh madres! estáis conformes con las teorías aquí desarrolladas (que creo lo estaréis, porque esa época sería el reinado de la armonía y del bienestar general) enseñad a vuestros hijos los redentores ideales del Comunismo Anárquico que es el que nos ha de proporcionar la verdadera Libertad, IguALDAd y FRATERNIDAD.

Enseñadles a luchar por la emancipación y por el bienestar humano para llegar de esta manera a ser libres (que hoy por hoy no lo somos) y poder hombres y mujeres darnos un abrazo fraternal, en señal de paz y armonía, sin preocuparnos de nada ni para nada de la asquerosa educación y de la corrompida moral burguesa.

Enseñadles que el Comunismo Anárquico es la paz y la felicidad universal, la idea de la nueva generación.

¡Madres! Enseñad todas estas verdades a vuestros hijos, porque tened entendido que los niños de hoy serán los hombres del mañana. Y esta juventud que se desarrolla bajo tan sublimes auspicios será la que en día 
no lejano ejecutará todos los actos que escritos están en el libro del Porvenir. Entonces, compañeras, entonces mujeres que jamás os habéis preocupado de vuestra libertad, entonces, repito, levantará el grito de protesta y acordándose de las ideas y de los sentimientos que le inculcaron en su niñez, le dirá a los tiranos del mundo entero: Ya ha llegado la hora de que acaben nuestras preocupaciones por lo tanto os decimos que ¡NUESTRo Dios es la Humanidad! ¡Nuestra patria EL UNIVERSO! ¡NUESTRO GOBIERNO ES NUESTRA PROPIA VOLUNTAD!

Entonces, mujeres, ya no tendréis que llorar la partida de vuestros esposos, la deshonra de vuestras hijas, la muerte de vuestros hijos en los campos de batalla y vosotras joh, jóvenes! no tendréis que temer absolutamente nada, si por casualidad dais satisfacción a esa ley ineludible de la naturaleza que os conduce a efectuar ese lema de "Creced y multiplicaos".

No tendréis nada que temer porque nadie podrá titularos adúlteras ni prostitutas, porque no se reconocerá en el hombre y la mujer más que unos tantos seres humanos que necesitan el goce mutuo para el desarrollo y conservación de sus cuerpos.

Sólo entonces, compañeras, reinará la dicha, el bienestar, y ese amor o afinidad entre hombre y mujer será quizás más duradero porque ella será despojada de toda clase de convencionalismos.

Por lo tanto, compañeras, luchemos sin descanso para destruir esta organización burguesa que nos aniquila y nos conduce lenta y gradualmente a los extremos más degradantes y tratemos de levantar lo más pronto la deseada Revolución Social, a los gritos de

¡Atrás los tiranos! ¡Paso al Progreso! ¡Viva la Paz Universal! ¡Viva la Anarquía!

Luisa Violeta

\section{LA INMUNDA CLOACA CLERICAL}

Compañeras de LA Voz de la Mujer, Salud:

Al narrar el atentado (1) de que estuve a punto de ser víctima decía, entre otras cosas, que podía narrar muchos casos análogos de los cuales han sido víctimas algunas de mis compañeras de infancia.

Ahora bien, muchos al leer el relato de la Confesión habrán creído que es una farsa inventada por mí para dañar la buena reputación de esos no menos buenos señores.

Pero, para que vean que no son farsas, y sí cosas reales que a diario acontecen, transcribiré una pequeña nota publicada no hace mucho tiempo por el diario "Giordano Bruno", que se publicaba en esta capital.

Habla el diario... y Uds. escuchen:

\section{ASUNTOS PENDIENTES}

"Francisco Ponza, violador de Catalina Toninetti en la Colonia Trébol, continúa impune. ¿No habrá algún lector que sepa dónde anda?

(1) Titulado Hecho Histórico, núm. 3 de "La Voz de la Mujer". 
Del cura Rassore de La Plata, violador de dos niñas, no se sabe nada y su asunto sigue encarpetado.

Los fetos de Puente Alsina... bien de salud. Las dignas madres... tan tranquilas en su casa.

El presbítero Iglesias, violador de una niña de diez años en la Colonia San Justo, continúa diciendo misa en el Convento de San Francisco, en Santa $\mathrm{Fe}$ (sic).

El jefe que en el Rosario ordenó los 200 azotes al soldado Netto y el capitán que hirió a Felipe Guzmán continúan sin novedad en su importante salud.

Esas monjas Catalinas prosiguen el sistema de las palizas con sus pobres dementes, y a pesar de nuestras denuncias nada se ha hecho para evitar que siga realizándose este método de curación."

Y bien, ¿qué os parece todo esto, compañeras? ¿son falsas por ventura estas cosas? No, porque de lo contrario los señores clericales ya habrían puesto el grito en el cielo, diciendo que los que tal cosa escriben son unos calumniadores, asesinos, apóstatas, y otras tantas lindezas escritas en estilo puramente clerical; ya hubieran gestionado y puesto en movimiento todo el personal de la inmunda cloaca para pedir ante las autoridades el castigo de los culpables.

Pero no, ellos callan y bien sabrán el porqué, ellos no dicen una palabra sobre los hechos denunciados, ni tan siquiera los desmienten. ¿Sabéis compañeros que desde el tiempo de San Pedro hasta hoy que ocupa la silla papal León XIII, siempre estuvieron metiendo las manos en el fango?
Formaos una idea ¡oh, mujeres! de todos estos crímenes y muchos más que quedan ignorados, y decidme después si no hay razón para odiarlos.

$$
\begin{array}{ll} 
& * \\
* & *
\end{array}
$$

El diario en cuestión, en uno de sus número pedía el castigo de los culpables.

¿Ignoran acaso los individuos que escriben ese diario que el pedir castigo de los culpables es pedir peras al olmo? ¿No saben que ellos son los señores de horca y cuchillo y derecho de pernada, de la sociedad actual, que dominan en todas partes y que sus primeros protectores son la AUTORIDAD Y EL GOBIERNO?

$\mathrm{Y}$ aun suponiendo que sean castigados esos sátiros, nada se remediaría, porque deben saber esos individuos que el castigarlos no sería más que atender a los efectos, dejando intactas las causas; vendría a ser lo mismo que si nosotros matáramos una hormiga que viniera a dañarnos una planta, porque mientras no destruyamos el hormiguero será inútil pretender acabar con las hormigas.

Pues bien, lo mismo sucede con esta cáfila de infames y cobardes; mientras castiguemos los efectos y dejemos subsistentes las causas, siempre violarán niñas de diez años de edad, es decir que mientras no destruyamos el hormiguero (léase iglesias, conventos, etc.) será inútil pretender acabar con esas hormigas dañinas (curas, frailes, etcétera).

¿No saben esos individuos que solamente hay un medio para acabar con esa cuadrilla de ladrones, asesinos, explotadores en nombre de Dios, 
de hipócritas, cuyo jefe tiene su residencia en Roma? Sí, ladrones y asesinos y si no acordaos del cura Santa Cruz en la guerra civil del 70 al 75 en España, de San Vicente Ferrer en la Cruzadas contra los moros, del cura de Olavarría Castro Rodríguez, asesino de su mujer e hija, etc., etcétera.

Pues bien, ¿sabéis cómo lograremos destruirlos? Os lo voy a decir: ellos emplearon la hipocresía, el fuego, el puñal y el veneno para apoderarse de los bienes de los unos, sacar a otros de en medio porque les estorbaban; por el fuego, el puñal y el veneno consiguieron embrutecer y aniquilar la Humanidad, y sino recordad a Gerónimo de Praga y a Giordano Bruno quemados por orden de la santa madre iglesia, a Galileo preso en inmundas prisiones por la misma orden, a Ganganelli (papa), envenenado por orden de los cardenales, porque no estaba conforme con sus latrocinios; la matanza de los hugonotes, la noche de San Bartolomé, en Francia, etc., etc.; pues, las armas de que se han valido para aniquilar y embrutecer la Humanidad, empleémoslas nosotros para destruirlos a ellos y para libertar al género humano del ominoso yugo que lo tiene sujeto.

Sólo de esta manera acabaremos con iglesias y conventos, verdaderas casas de prostitución donde se cometen toda clase de infamias, como las de apalear a infelices dementes, infamia, sí, porque los infelices dementes necesitan de la ayuda de la ciencia y no las palizas que les propinan esas hipócritas prostitutas que se ocultan bajo el nombre de monjas.

Sí, esas prostitutas parásitas de la sociedad, que después de satisfacer sus apetitos carnales en compañía de... los santos varones, o sea los curas, arrojan el fruto de sus entrañas en las calles (y si no los fetos hallados en Puente Alsina, que salieron de un convento que hay en las inmediaciones) o los entierran en el jardín del convento.

Para que toda esta corrupción (escarnio de un pueblo que se dice civilizado) desaparezca, es necesario que os unáis a nosotras y cuando tengáis convicción del porqué lucháis, entonces de acuerdo con nuestros compañeros, tratemos de provocar la gran Revolución Social.

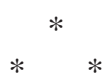

Los individuos que escriben el diario antes mencionado creo que deben comprender que no se destruyen las causas castigando simplemente los efectos. Ellos comprenden que nada se consigue y si no lo manifiestan públicamente, es porque sería darnos razón a nosotros y no les conviene dar aliento a nuestras avanzadas ideas; es porque saben que para destruir causas y efectos, nuestra divisa es: ¡No más explotación! ¡no más fanatismo! ¡no más gobernantes ni gobernados, ni ricos ni pobres!

A ellos no les conviene nada de esto porque les gusta mejor pasar la vida de paseo y en escribir muchos artículos que no tienen más objeto que embrutecer a los incautos que los crean.

Pero por desgracia ya se os conoce bien ¡canallas mistificadores! ya no encontraréis terreno propicio para sembrar vuestras falsas ideas. Ya hemos visto lo que es la democracia de la cual mucho hemos esperado y nada 
conseguimos; ya sabemos por experiencia propia que donde hay autoridad no puede haber libertad y por lo tanto toda clase de gobierno significa opresión, tiranía.

En cuanto a la decantada separación de la Iglesia y del Estado, no es más que vana palabrería, pues ya sabéis que el gobierno y el capital precisan: un fraile que con la cruz embrutezca a las masas, un juez que castigue y un militar que asesine cuando noten síntomas de agitación en el pueblo; es también un dique que pretendéis oponer a las masas populares justamente resentidas contras los asesinos de la Humanidad, son paliativos que queréis aplicar para detener el majestuoso avance de ese gran oleaje que designamos con el nombre de Revolución Social.

Pero, lo repetimos, os conocemos demasiado para que podáis engañarnos de nuevo, y trataremos de presentaros ante el pueblo, tal como sois, esto es ambiciosos que queréis agarrar la sartén por el mango y deseos de vivir en il dolce far niente.

Nos habláis de separación de la Iglesia y del Estado, de moral administrativa, etc., perfectamente, pero nosotros conscientes de lo que somos y de lo que deseamos, os decimos: no la separación de esas dos calamidades, que representan la una el embrutecimiento y la prostitución y el otro la tiranía, sino la abolición.

Pero no hay cuidado, pues ya sabemos el remedio: sí, ése será la Revolución Social que barrerá de una vez por todas, todos esos prejuicios de Patria, religión, burguesía, capitalismo, magistratura, en fin, de todas estas miasmas corruptoras que desolan la Humanidad.
Una vez destruido todo esto, implantaremos el reinado de la verdadera Libertad, Igualdad, Fraternidad; entonces será un hecho la armonía, la paz, la tranquilidad, en fin, entonces plantearemos el Comunismo Anárquico.

Mientras tanto no lleguemos a estas supremas aspiraciones, luchemos y fustiguemos sin descanso a los ladrones de sotana y de guante y levita.

¡Viva la Anarquía!

¡Viva la emancipación social!

¡Abajo los clericales del mundo entero!

Vuestra compañera

\section{Luisa Violeta} 米

\section{Contestación de dos Anarquistas}

Culpa no es nuestra y sí de la actual sociedad, que nuestra pobre inteligencia nos conduzca a cometer errores en ciertas apreciaciones, y mucho más en éstas, que por pertenecer a interés general, son para nosotros más difíciles de analizar con toda la claridad que requiere y que pudiera hacerlo una inteligencia medianamente cultivada. Y ésta es la razón de que nosotros concebimos una idea y no podemos desarrollarla; si nos arriesgamos a manifestarla, lo hacemos, además de incorrectamente, dejando siempre algunos puntos que den lugar a malas interpretaciones, como nos sucede en esta ocasión a "dos Anarquistas".

"Varios compañeros" en La Revolución Social no se han fijado más que en donde dice: "uniendo los esfuerzos de todos en uno o dos" para contestar a "Algo sobre periódicos anarquistas"; 
y lo que se desprende de "Una opinión" es que "dos Anarquistas" están conformes con centralizar la propaganda, siendo todo lo contrario; pero ipara qué vamos a repetir lo que ya hemos dicho en el núm. 3 de La Voz de la Mujer?

Los mismos compañeros que nos contestan dicen en su artículo que: "hay que fijarse en la utilidad que reporta el disponer de varios medios de propaganda, aun siendo a fuerza de cruentos sacrificios" que es la parte principal que atañe a la propaganda, y a los propagandistas -La cuestión económica. Esto es lo que nosotros, míseros propagandistas de la idea, creemos debe tomarse en cuenta, por ser lo más posible entre nosotros, a no ser que nos muevan rencillas personales o cosas por el estilo, lo cual a nada útil y provechoso conduce.

¿Tienen o tenemos afinidades los compañeros de Buenos Aires?, si éstas existen, hagamos un arma de batalla que combata a la prensa asalariada y a la burguesía explotadora, ya sea diaria, semanal o quincenalmente, pero que se cuente con ella; y después vengan iniciativas a millares que todas son buenas cuando éstas vienen de buena fe. Así es que no podemos por menos que concluir estas líneas como concluyen las suyas "Varios compañeros".

¡Viva la iniciativa libre!

\section{Las tres maldiciones}

Con ojos secos, lúgubres, ardientes

Rechinando los dientes

Se sienta en su telar el tejedor

Germania vieja, tu capuz zurcimos
Tres veces, tres, la maldición urdimos

Adelante, adelante el tejedor.

Maldito el falso Dios, que implora en vano.

En invierno tirano

Muerto de hambre el jayán en su obrador

En vano fue la queja y la esperanza

Al Dios que nos burló guerra y venganza

Adelante, adelante el tejedor.

Maldito el falso Rey, el poderoso

Cuyo pecho orgulloso,

Nuestra angustia mortal no conmovió

El último doblón nos arrebata

Y como a perros luego el Rey nos mata

Adelante, adelante el tejedor.

Maldito el falso estado en que florece

Y como yedra crece

Vasto y sin tasa el público baldón

Donde la tempestad la flor avienta

Y el gusano con podre se sustenta

Adelante, adelante el tejedor.

Corre, corre sin miedo tela mía

Corre bien, noche y día

Tierra maldita, tierra sin honor

Gemania vieja tu capuz zurcimos

Tres veces, tres la maldición urdimos

Adelante, adelante el tejedor.

E. Heine

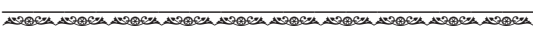

\section{Un poco de todo}

Se avisa a los lectores de este periódico que su vida depende de la ayuda moral y material que se le preste, por lo tanto esperamos el apoyo necesario para publicarlo con toda regularidad.

Al mismo tiempo pedimos a los compañeros que traten de hacerlo circular entre las mujeres, ya sea en las casas de vecindad o en los talleres.

米 
En un manifiesto publicado por $\mathrm{F}$. Denambride se hacen cargos contra la Redacción de LA Voz de LA Mujer que no creemos prudente dejar pasar en silencio.

$\mathrm{Ni}$ el periódico está en manos del Grupito Amor Libre, ni menos ha sido rechazada la carta de la compañera Lagouardette, aun cuando haya individuos que pretendan asegurar lo contrario.

Hacemos esta declaración por lo que pudiera suceder y no por renovar cuestiones personales, pues éstas nos dan asco tratarlas.

\section{*}

El día 4 de abril ha fallecido nuestro apreciable compañero Felipe Vázquez (a) Canario.

Aunque no orador ni escritor, el compañero Vázquez ha prestado por su actividad importantes servicios a la causa que defendemos.

Ahora recomendamos al señor jefe de policía que puede retirar el retrato de nuestro compañero, pues la muerte encargóse de inutilizarlo; y tengan entendido todos los que toman esas precauciones que de nada les valen cuando un hombre está decidido a cometer cualquier atentado.

\section{*}

Nuevo Campeón. Con el título de "Antivaktng" (Despertar) se va a publicar un periódico comunista-anárquico en Amberes.

Su dirección es Mr. Victor Resseler Haausjeslei 119, Amberes, Bélgica.

\section{米}

Dice un periódico:

"Hay en París una policía llamada de las costumbres, que corresponde a la que en España se llama del 'ramo de higiene'. Aparte de lo del nombre, no hay ninguna diferencia entre ambas, pues si la española comete abusos, no comete menores la francesa. Ayer, sin ir más lejos, dos de esos agentes, que deberían llamarse de las malas costumbres, se echaron encima de una pobre joven que acababa de salir de casa de sus padres para comprar algunos comestibles, y emplearon con ella todo ese vocabulario soez que sólo se oye en los burdeles, llevándola por fin al cuartelilllo de policía, donde la infeliz pudo justificar que era una muchacha honrada.

¿No sería preferible que todas las mujeres perdidas anduvieran libremente por la calle, antes que darse el caso de atropellar tan brutalmente a una infeliz que vive honradamente con su familia?"

Este suelto reproducido por El Corsario del cual lo hemos tomado, nos demuestra claramente la seguridad individual que reina en la democrática república francesa.

Ahora bien, después de leer esto ¿quién es que no se subleva? Sólo los canallas pueden permanecer indiferentes a estos hechos.

La sociedad burguesa nos empuja al vicio y quieren después castigar los efectos de su propia obra.

¡A canallas! Nuestra venganza será terrible.

\section{*}

De El Liberal:

Zaragoza (24-11.15 a.m.) - Dos soldados de los regimientos de Cádiz y Alfonso XIII llegaron enfermos a 
Cádiz. Allí les dieron los pases para Huesca, pero sin recurso alguno.

Compadecidos los viajeros que venían en el tren con dichos soldados, les vinieron dando de comer hasta Madrid, donde Segundo Rodríguez, obrero, hijo de Zaragoza, les pagó el viaje hasta esta capital.

Aquí han inspirado verdadera lástima, socorriéndolos varias personas y la Sociedad El Ruido.

Se lamenta todo el mundo de la conducta seguida con los defensores de la patria, y se elogia en cambio el proceder del obrero Rodríguez. Darío

¡Bravo! ¡Muy bien!

Así paga la patria a los imbéciles que se prestan a servir de instrumento a los que viven a costa de ellas.

¡Lástima de pesebres y bozales!

$$
\text { * }
$$

\section{Leemos en El Corsario:}

"Ha fallecido en Viñuelas (Málaga) una joven de dieciocho años por la causa siguiente:

La noche del Jueves Santo de 1894 llevóla su madre a la iglesia, donde permanecieron toda la noche, previo el permiso del cura.

Húmeda la iglesia, la noche fría, la joven llena de miedo, dos hermanitos suyos llorando a la puerta por no poder entrar, todo esto contribuyó a que le acometiera una fuerte calentura, que se le repitió hasta degenerar en tisis.

A estos y otros casos por el estilo es precisamente a los que conduce ese bárbaro fanatismo desgraciadamente tan arraigado en muchas personas.

El caso anterior iservirales de escarmiento a esas sencillas gentes?

¿Pero Señor Dios cómo es que pagas tan mal las plegarias de tus fieles adoradores?

¿Dónde está tu poder? ya se ve estás $\tan$ viejo que no sabes lo que haces; debíamos llevarte al depósito de trastos viejos.

$$
\text { 米 }
$$

Los señores socialistas han visto "coronados sus esfuerzos" en el meeting del domingo 19 del pasado.

Inmensa concurrencia se esperaba asistiría a oír los aullidos de los Excmos. señores Payró y Patroni.

Pero ¡oh decepción! el pueblo no sabe apreciar lo que valen esos señores y por lo tanto encontró prudente encerrarse en su casa o pasearse a sus anchas.

Esto no obstante no impidió el que un compañero cansado de escuchar los aullidos de dichos aspirantes a la olla (diputación) quisiera correrlos un poco por lo cual los demás miembros infalibles de la jauría empezaron a ladrar hasta que intervinieron sus hermanitos los perros, que tienen por divisa un gallo... que a nuestro parecer nada ven, los cuales prendieron a tres de nuestros compañeros.

$$
\text { 米 }
$$

Los compañeros de Oporto nos comunican que en el transcurso de este mes quedará lista "La conquista del pan", traducida al portugués.

Los compañeros que conozcan este idioma pueden solicitarla a los compañeros de "O Libertario", Rua da Pena, Ventosa $5,2^{\circ}$ Porto (Portugal).

$$
\text { 米 }
$$

Con el nombre de "Armonía" quedó constituida en ésta un grupo que 
se propone ensayar y dar funciones dramáticas.

Las obras que piensan poner en escena los compañeros de este grupo son las que responden a las ideas modernas, tales como Los Aparecidos y Un Enemigo del Pueblo, de Ibsen, Magda de Sunderman, El pan del Pobre, Los Tejedores, etcétera.

Para comunicarse con el grupo dirigirse a cualquier periódico en curso de publicación en nombre de J. M.

\section{ÚLTIMA HORA}

\section{A LOS DEFENSORES DE \\ FRANCISCO DENAMBRIDE}

Estando nuestro periódico en máquina, tuvimos conocimiento que la compañera Anita Lagouardette presentóse, acompañada de otros compañeros, en casa de F. Denambride (su esposo) para pedirle que le entregase sus ropas, pues habiendo terminado su afinidad con él, se retiraba.

Pues bien, el pretendido anárquico Denambride solicitó de los acompañantes se retirasen pues tenía que hablar particularmente con ella; dichos compañeros se retiraron a la puerta de calle, enseguida cinco detonaciones de revólver venían a demostrarnos cómo respeta dicho señor la libertad individual.

Por fortuna, de los cinco disparos sólo dos pudieron hacer algo aunque poca cosa, pues las heridas son leves.

¿Qué contestan aquel o aquellos individuos que constituyéndose en jueces se han proporcionado en un periódico (1) una patente de honor y de anarquía?

El proceder de ese individuo no es de anarquista, es de un verdadero burgués disfrazado, pero burgués despótico y tirano.

Si hombres de esta especie pueden llamarse anarquistas y considerarse como tales ¿por qué no consideran también como tales a los burgueses y a los inconscientes que obran de idéntico modo?

¡Qué vergüenza!

La Voz de la Mujer como defensora de los ideales del Comunismo-Anárquico y, por lo tanto, de la libertad de la mujer, no tiene por menos de estigmatizar el cobarde atentado del día 11 contra la libertad y la vida de una compañera. Éstas, pues, no son cuestiones personales sino causas que perjudican la idea.

En el próximo número trataremos de analizar todos estos actos que muchos $[\ldots]^{*}$ personales bajo el punto de vista de los perjuicios a las ideas.

La Redacción

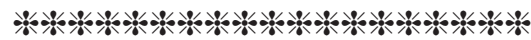

\section{SOLIDARIDAD}

No teniendo ni admitiendo los anarquistas sociedades de socorros mutuos, tienen forzosamente que ayudarse por ese mutuo principio de Solidaridad.

Decimos esto por ver que "El Perseguido" tiene iniciada, hace mucho tiempo, una suscripción a favor de un compañero preso, y sin embargo los

1) No atacamos al periódico sino a los autores del suelto.

* Se señalará [...] el texto ilegible [N. del E.]. 
resultados no son eficaces, y nosotras hará tres meses que levantamos una, para la hija del compañero Salvador y ya pueden ver los resultados que da.

Sería de desear que los compañeros hiciesen más general este principio libre de ayuda mutua, pues si nosotros no lo hacemos, no será ciertamente nuestra irreconciliable enemiga la burguesía quien lo hará.

\section{La Redacción}

\section{Suscripción a favor de la niña Libertad \\ $\rightarrow \rightarrow$}

Ceytun 1.00, Ni gapa 1.00, Bernardo Burgos 2.00, Anónimo 0.50, Barítono 0.30, Un sastre explotado 0.40, Vino Barbera 0.30, Yo 0.50, Pietro 0.50, Roma 1.00, Bestelli 0.40, Bicho feo 0.40, Bomba 0.45. Total pesos 8,65.

A deducir 1.75 correspondientes a la familia Ragazzini y destinados por éste a La Voz de la Mujer.

Quedan para la niña Libertad 6.90.

Continúa abierta la suscripción.

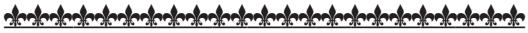

Suscripción voluntaria

A FAVOR DE

"LA VOZ DE LA MUJER" :̊::

\section{Capital}

J. R. 0.25, M.M. 0.10, Desesperado 0.20 , Oriental albañil 0.20 , Un miserable 0.05, Niña Libertad 0.20, Una mujer rebelde 0.20, Cualquiera 0.20, Cualquier cosa 0.50, Champurriado 0.50, Burgués gallego 1.00, Fundidor asturiano 0.50, Ragazzini 0.15 , Un sastre explotado 0.20, Vicente 1.00, recolectado en la Matadora 1.70, Uno que se quedó con las ganas 0.90, Un hijo de la Anarquía 0.25 , vuelto de una convidada en el café Romano 0.90, A. Lanfranconi 0.50 , sobrante de copas 0.35 , el hombre que no protesta contra las infamias de su patrón es un bestia 0.50 , que capen del primer monaguillo al Papa 0.50, Ferrari 0.15, Otro 0.05, Ragazzini 1.75, Uno 0.15, Uno que desea empezar a degollar burgueses, burguesas y burguesillos 0.20 .

-Por conducto de "La Revolución Social":

Lista extraviada 1.80 .

GRUPO "EL BIENESTAR PARA TODOS"

Uno que se ha unido libremente con una compañera 0.50, Esclavos imitémosle 0.25 , abajo las instituciones religiosas y civiles 0.50, ¡Viva el amor libre! 0.10.

- Por conducto de Caserio:

Picapedrero 0.20, Revolución 1.00.

- Por medio de "La Libre Iniciativa":

De una suscripción levantada en la Boca para los presos y destinada a la propaganda 1.00 .

- Por conducto de "La Questione Sociale":

Fumo sin estampilla 0.40, un encartonado 0.20 , Torpedo 0.20 , un explotado 0.20, un dramático 0.30, Cacocoba 0.10, San Pedro 0.25, admirador de Caserio 0.20, Serafín Melani 0.30, Estoy cansado de fumar con estampilla 0.20, fumo un jefe borrachón 0.20, Ras Al La 0.20, Baratieri 0.20, de cada cura, dos 0.20, San Pablo 0.20 , Un triste aficionado 0.20 , Un antianarquista será colgado 0.20 , Reparto de la suscripción de Barracas para los presos 1.00.

- Por conducto de Luisa Violeta:

Lista extraviada 0.70 , una planchadora 0.30, una que capó un fraile 0.50 .

- Suscripción para la propaganda levantada en Barracas:

Uno que no tiene nariz 1.00 , uno que se tiñe el pelo 0.20 , un belga 0.20 , un pobre diablo 0.20 , un oriental albañil 0.50, Venga pronto la Anarquía 0.50, un 
brasilero que quiere la venganza de San Pablo 0.50, uno de Barracas al Sud 0.20, sobrante del bote 0.30. Total 3.60.

Repartido:

0.85 para "El Perseguido"; 0.85 para "El Oprimido", 0.85 para "La Cíclope" y 0.85 para "La Voz de la Mujer".

Recolectado el 26 de abril en la Boca pesos 9.45, Solanich 0.20, Viva el amor libre 0.20, N. A. 0.80, Burgués gallego 1.00, Vicho 0.50, bien por Mosquerón 0.15 , Baigorria 0.20 , vuelto de copas 0.70 , una pistola para levantar la tapa de los sesos a los burgueses 0.50 .

\section{Interior}

Chivilcoy: "Grupo Revachol"- Donde vas con mantón de Manila 0.50, Orsini Vidal 0.50 , una compañera 0.30 , un radical falsificado 0.40, Orsini Vidal 0.50, un marinero sin barco 0.40 .

Coronel Zelaya-Félix Contreras 0.50

Sarmiento-E. Medina 0.40.

Mar del Plata: El que roba por hábito es un burgués al menudeo 0.80 , el que roba dinero de la propaganda es la depravación personificada 0.50 . Siendo ladrón del dinero de la propaganda comunista-anárquica es lo que podemos llamar un pobre hombre 0.75 , el que roba a un pobre es un vil 0.50 .

- Por conducto de "La Anarquía" La Plata-Virgilio Olginte 1.25, Juan el cochero 0.50, V. O. 0.50.

Patagones- C G. 5, C.V. 2, B. V. 2.

San Isidro- Por conducto del Zapatero: De varios compañeros 1.00, Por medio de Barri 1.00.

-Por conducto de "El Perseguido": De campana 1.00 .
Total recolectado 56.40. Gastos del presente número: por impresión de 2.000 ejemplares 55. Entregado lo que se adeudaba a "La Libre Iniciativa" 1.00. Déficit anterior 4.50. Expedición y otros 8.50. Déficit actual ps 13.10 .

Nota: Se ruega a los compañeros traten de acortar los seudónimos de la lista de suscripción, pues nos roban mucho espacio que podría ser dedicado a cosas de más utilidad.

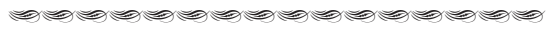

\section{CORRESPONDENCIA}

Coruña - "El Corsario". Recibimos "Procesos" pero no las obras dramáticas pedidas. Atendemos los pedidos que hacéis.

Madrid - "La Idea Libre" ¿Os habéis muerto?

Soledad Gustavo, Luisa Michel, Emma Goldman, Rosario de Acuña: os hemos escrito, ¿habéis recibido las cartas?

Brooklin- Grupo El Ideal. Mandad algunos Mensajes, si es que tenéis.

El Esclavo, La Sociale, La Débacle Sociale, Nouvelle Humanité, L'amí des Ouvriers. ¿Habéis recibido el periódico?

Barcelona- "Ciencia Social" ¿Podrías remitirnos un ejemplar de cada número atrasado?

Barcelona- J. Suñé. Manda folletos, si puedes.

Rens - I Médico. Lo mismo te decimos. 
Apéndice de "La Voz de la Mujer"

\section{EMILIA Y LUCÍA}

\author{
POR \\ ร. ฯ. ฯ. \\ $3 x^{2}$
}

BUENOS AIRES

1896

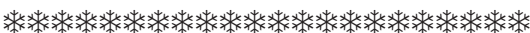

\section{AL LECTOR}

Cuando me he propuesto dar comienzo a este pequeño trabajo, no me impulsaron ideas mezquinas, ni albergué en mi pecho la esperanza de torpes aplausos. El único móvil que me impulsó a tomar esta decisión fue el de coadyuvar con mi grano de arena a la construcción de ese gran edificio llamado Comunismo Anárquico.

No encontraréis en el transcurso del presente opúsculo, períodos literarios que halaguen el sentido ni menos esa gran lógica y retórica que caracteriza las obras de los grandes filósofos.

Así pues, hecha esta advertencia, sólo me resta deciros que tendría una gran satisfacción en haber conseguido el objeto que se propone.

El Autor

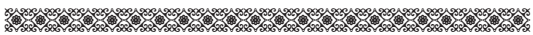

\section{EMILIA Y LUCÍA}

Emilia: -Señora Lucía ¿dónde va tan apurada que no puede atender el llamado de sus amigas?
Lucía: -¿Amigas? No, no puedo creer que puedan existir amigas en una sociedad basada en el vicio más desenfrenado, encubierto bajo la hipócrita máscara de una moral que nos tiene sujetas como la cadena sujeta al perro.

Emilia: -¿Cómo? ¿Acaso no eras tú mi compañera en los juegos de la infacia, la que venía acompañándome cuando iba a la escuela donde aprendía las primeras letras? ¿No eras tú la que me decías que jamás romperíamos los lazos que vinculaban nuestra amistad?

Te he escuchado y me parece extraño que seas tú la que hablas, tú que tanto cariño me habías demostrado.

Lucía: -Sí, fui tu compañera en los juegos de la infancia, es cierto que iba siempre contigo a la escuela y también lo es que en mi niñez o, mejor dicho, cuando todavía no comprendía lo que es el mundo, te había jurado amistad perpetua; pero desde aquella época las cosas han variado notablemente. Hemos seguido, por desgracia, dos caminos muy opuestos: yo en pro de la más completa libertad de todos los seres humanos y tú por el camino del oscurantismo. Es por este motivo que no podemos ser amigas y tenemos forzosamente que ser rivales. ¿Puedes creer que pueda haber amistad entre nosotras desde el momento que tú adoras a un Dios, respetas y propagas la religión por doquier y acatas toda clase de actos de nuestros tiranos que nos roban impunemente, que obligan a nuestros esposos e hijos a llevar una vida errante y miserable y a nosotras a bucear en la prostitución el pan para nosotras y nuestras tiernas criaturas, mientras que yo propago 
por todas partes donde me hallo la más completa libertad para todos; en fin, para concluir con dos palabras, que busco los más altos conocimientos científicos y profesionales para el género humano y que sea una realidad la armonía universal?

No, Emilia, no; tiempo es que comprendas que yo no puedo ser tu amiga, te basta saber que pertenezco a esa secta de locos, de ilusos, de utópicos, que soy, en fin, partidaria de los ideales del Comunismo Anárquico.

He llevado largo tiempo estudiando y razonando sobre las cuestiones políticas y sociales, religiosas y ateas, conservadoras y revolucionarias. He estudiado teórica y prácticamente la vida del hogar: he visto hombres y mujeres, niños y ancianos, hambrientos y haraposos, vagar de un lado al otro de la ciudad, pidiendo trabajo los unos y recogiendo los desperdicios de los cajones de la basura los otros; he penetrado en esos muladares llamados por irrisión Casas de Misericordia, asilos de mendicidad, etc., y observé aquellas mujeres de hábito azul unas y negro otras, en las cuales los sentimientos de humanidad son letras muertas y que son capaces de llegar hasta el crimen en aras de su fanatismo y por último he visto a nuestras desgraciadas compañeras salir tristes y meditabundas con lágrimas en los ojos y enrojecido semblante, de las casas en las cuales habían entrado a servir, porque halagadas por falsas promesas, seducidas con hermosas palabras, habían entregado su cuerpo a esos infames explotadores.

Y no contentos todavía con robar al amparo de la ley a nuestros padres, hermanos o esposos en sus talleres, les lan- zan al rostro la pretendida deshonra de nuestras madres, hermanos e hijos, llevando su crueldad hasta el extremo de señalarlas unos a los otros, cuando por casualidad los tropiezan en su camino.

Fue después de observar todo esto que mis sentimientos me impulsaron los ideales de los pretendidos locos, asesinos, ilusos y otros tantos nombres con que designan a los propagandistas de la Revolución Social. Fue, repito, después de un maduro examen que me decidí a afrontar los peligros que una vida errante y azarosa podía acarrearme y por último el recuerdo de otras mujeres que ya andaban mezcladas en la lucha me decidió a tomar mi puesto de combate en las filas de los autónomos soldados del Comunismo Anárquico.

Ésta es, Emilia, en pequeños rasgos, la historia de mi cambio de ideales, pues no debes ignorar que en mis tiempos fui tan religiosa como tú.

Emilia: -Te he escuchado y confieso francamente que el cambio que en ti se ha operado ha sido muy grandioso. Observo tu rostro animarse en el transcurso de la discusión: veo en ti que no eres aquella gentil y gallarda niña de noble estirpe, que salías tan tranquilamente de tu casa y con paso corto pero ligero te dirigías a San Martín a elevar tus plegarias al Omnipotente y regresabas poco después ufana y satisfecha de haber cumplido con la obligación, poniéndote después a bordar cualquier prenda que se te entregaba.

¿Recuerdas aquel hermoso cuadro que hiciste representando al genio divino destrozando al genio incrédulo? ¿Y aquel otro que bordaste, cuando tu primera comunión que te valió el aprecio de propios y extraños? ¿No 
eras tú acaso llamada la Virgen de la Aldea por tus obras piadosas para con los pobres? ¡Ah, Lucía! ¡Cuánto has variado en tus costumbres!

Hoy no vas a misa; no das una triste limosna a los pobres; te metes en todas partes propagando esas heréticas doctrinas, sin respetar ni la moral ni las leyes; tú no hay sitio donde se llame a los pobres que no te presentes anatematizando el orden actual de las cosas; combates la sagrada institución del matrimonio, en fin que has variado notablemente.

¿Sin gobierno qué será de nosotros? Los hombres nos maltratarían, querrían $[\ldots]^{*}$

* El texto se interrumpe abruptamente [N. del E.]. 



\section{LA VOZ DE LA MUJER}

\begin{tabular}{ccc}
\hline \hline $\begin{array}{c}\text { Aparece cuando puede } \\
\text { por suscripción voluntaria }\end{array}$ & Periódico Comunista-Anárquico & $\begin{array}{c}\text { Dirección: A. BARCLA } \\
\text { Casilla Correo 1277 - Capital }\end{array}$ \\
\hline \hline
\end{tabular}

\section{SILUETAS}

Ésta es la primera de una serie que nos proponemos publicar figurando entre ellas: el Juez, el Fraile, el militar, etcétera.

$\rightarrow \rightarrow$

¡Se trata ni más ni menos que de mi unión! ¿Queréis saber con quién? Escuchad pues.

Altivo, sin pedantería ridícula, cariñoso y noble en su proceder, desprendido y generoso, cuanto sus medios de vida se lo permitan, pero sin vanidad ni hipocresía; franco, sin exageraciones, es celoso defensor de su dignidad de persona, de su libre albedrío e independiente individualidad, así como también de la de sus camaradas y compañeros a quienes ama sin interés, ni egoísmo alguno.

Sencillo en sus modales, y en su conversación, que siempre se os hace agradable y atrayente, es decir, simpática, por sus ideas de fraternidad, de paz, amor y de progreso social, y por la noble y leal franqueza con que os las explica y da a conocer; siente vuestros males y dolores casi tanto como vosotros mismos; compasivo y amante de la humanidad, le oiréis fustigar sin piedad y con fogosa vehemencia la causa de los males que afligen a la humanidad.

Su corazón ardiente y generoso palpita al unísono del de todos los que sufren y lloran, pero a él pocas veces le veréis abatido o lloroso, porque su corazón sereno y fuerte, forjado en el yunque del dolor, y los padecimientos físico-intelectuales, se aviene más con la lucha que con el lamento, esto es tratándose de sí propio. Por eso habrés oído decir de él que es sanguinario, cruel, lo cual es mentira. Él es altivo y rebelde, sí, pero no cruel ni despiadado.

Él no sabe rogar ni implorar, por eso cuando se siente herido se rebela y subleva, repele con violentos estallidos de cólera la agresión de que se lo hizo víctima. ¿Qué hay de malo en ello? ¿Si os pegan no defenderéis acaso?

Sintiendo como siente los dolores ajenos tanto como los propios, jamás dejará de aliviar los primeros si sus fuerzas se lo permiten, sin que por ello se crea con derecho a agradecimiento alguno ni tampoco más digno que antes de vuestra amistad o aprecio; porque dice que ayudar al caído es una necesidad de todos los corazones no corruptos.

Téngase entendido que esta ayuda mutua no es caridad en forma de socorro, pues la caridad la practican aquellos a quienes sobran medios de vida y esto es humillante para el que la recibe y es una ruindad por parte de quien la hace.

Compasivo y tierno, su corazón no guarda rencor para los que por ignorancia o [...] ofenden o desprecian; pero es implacable para con sus eternos e irreconciliables enemigos, que lo son los de la clase parásita y opre- 
sora, para los cuales no tiene piedad ni compasión, por reconocer que son ellos quienes lo obligan a una vida de dolor y miseria, haciéndole por esta causa estar en perpetua lucha y declarada guerra; lucha y guerra sin tregua ni cuartel, en la que ellos emplean todos los medios, desde el más infame al más horroroso, entre ellos la cárcel, la falsía, el error y la mentira, los cañones y el patíbulo, ante cuyas amenazas y golpes él, lejos de amedrentarse o rendirse, continúa firme y sereno, dando de vez en cuando formidables golpes a su contrario.

Un día yo le pregunté por qué siendo tan cariñoso, tan compasivo y noblemente tierno propagaba la destrucción y desplome de ciertas clases sociales.

¿No ves - me dijo- que son ellos los que me obligan a ello?

Mi corazón no aspira más que odio, doquier que voy hay injusticias, hay dolores y miserias, por doquier llanto y duelo, infamias y vilezas, ¿qué quieres que haga pues?

¡Oh - prosiguió con dolorida vehemencia- mi ardiente corazón no puede tanto, es preciso pues que yo luche, que me revuelva airado contra los causantes de tanta y tanta iniquidad, no hacerlo así sería ser cómplice de esas infamias!

No ataca jamás ni critica los efectos, sin antes haber analizado las causas.

Modesto y sencillo, jamás en su pecho tiene cabida el orgullo ni la estúpida vanidad, y lo mismo le veis subir a una silla o banco para desde allí manifestar a sus compañeros sus opiniones o bien con frases de ardiente vehemencia, anatematizar y fustigar sin piedad los perjuicios y ruindades sociales, que bajarse de una tribuna y perderse entre sus compañeros, sin vanidad, sin orgullo, sin afectada modestia.

El aplauso de los que lo oyen ni lo seduce ni halagan, y por el contrario, dice que esos aplausos no son para él, sino para sus ideas, porque éstas son las mismas de los que lo oyen, los cuales al aplaudirle sólo lo hacen para manifestarle su conformidad, pero jamás para mostrarle admiración. Dice, y con razón, que no hay lugar por elevado y honroso que sea, en el cual él no deba estar, pues se cree tan digno y con tanto derecho como el que más, sin pensar por esto que nadie sea menos que él, es decir, considera perfectamente iguales en derechos y necesidades a toda la raza humana.

En su persona es cuidadoso y limpio, tanto cuanto sus medios y ocupación se lo permitan.

$\mathrm{Su}$ porte es sumamente sencillo, demostrando casi siempre pobreza, pero jamás veréis en su persona los signos exteriores de la dejadez, pereza o haraganería. Amante de la higiene, hace para conservarla verdaderos sacrificios y la falta de ella en su persona u hogar es una de las razones que invoca, cuando os propaga sus ideales, diciendo que una sociedad que no le permite la satisfacción de esta necesidad y muchas otras, tales como la lectura, a que es sumamente afecto, es una mala y criminal sociedad, pues tiende a perpetuar la ignorancia y el embrutecimiento de los pueblos.

No creáis por esto que él desprecie o considere en menos al ignorante o al que no es limpio en su persona, no, 
él sabe perfectamente que por regla general es sucio quien no puede ser limpio o quien desconoce las ventajas de la higiene, y que quien desconoce esas ventajas y necesidades es un ignorante, y zquién quiere ser ignorante?, iquién desea serlo?, iquién tiene la culpa, quién es causa de la ignorancia y miseria del pueblo trabajador?

¡La clase exploradora, esa clase que él odia y detesta con todo corazón!

Por otra parte nunca lo veréis adornado con prendas ridículas ni aparatosas, ni llevar en sus dedos dijes más o menos relucientes, y por el contrario, es enemigo de la ostentación y de un lujo que, según él, es criminal, pues es tener ruin corazón el arrojar a la calle lo que otros necesitan.

Sumamente afecto a la lectura, analiza mucho todo cuanto lee, sin que jamás se deje sorprender por pomposas promesas ni mentidas descripciones.

En extremo afecto a la discusión, se expresa en ella con suma sencillez no fingida, aun cuando sí con entusiasmo y calor, pero sobre todo con franqueza.

Raras veces sus discusiones degeneran en disputas, dándose el caso en que a pesar de tener de su parte la fuerza y la razón, desdeñe las insinuaciones de una lucha a que se lo provoca y que él considera estúpida e improcedente, excepto de tratarse de uno de sus irreconciliables enemigos, pues en tal caso no vacilará en aceptar y hasta en atacar, pues sabe que éstos, por el contrario de los obreros, discuten y ultrajan por mala fe, por egoísmo y por maldad.

"Es más enemigo suyo quien es más autoritario."
Luchador infatigable y decidido, es un propagandista activísimo de sus teorías, ya sea por la palabra o por la pluma, no desperdiciando ocasión que se le presente, ya en el taller, ya en el hogar.

Explica sus ideas con cuanta claridad se lo permiten sus conocimientos, poco profundos, pero bastante extensos si se tiene en cuenta la mala y poca educación recibida.

Cuando propaga sus ideales, lo hace con franqueza y lealtad, pero sin ultrajar ni insultar, pues considera mucho el medio ambiente en que se vive, pero no creáis que por esto oculta o mistifica sus ideas, no, las presenta tal cual son, de progreso, de paz y de amor e igualdad, explicando las causas que producen los violentos estallidos de su cólera justiciera.

Nada le importa el concepto en que sus enemigos o los inconscientes le puedan tener, pues no acata ni reconoce más juez que su severa razón y corazón, franco altivo y leal.

Esto es en su faz exterior.

$$
\text { * }
$$

En el hogar es sumamente tierno y cariñoso para con los niños y la mujer, no por creerse su protector sino simplemente por cariño.

Ama y trata con dulzura a su esposa, a quien llama "compañera", frase cuyo significado dice por sí solo que en su hogar hay un amor dulce y sereno, puro y constante afecto, que códigos, leyes, curias ni registros no pueden dar jamás.

Si halla faltas en su compañera se las hace notar con dulzura, tratando 
de evitarlas y combatirlas con ejemplos y cariñosos consejos, sin hacer valer una autoridad, preponderancia o superioridad que él niega tener, y si se diera el caso poco probable de que ella no atendiera o no fuera posible, ya por cierta clase de carácter, o bien por temperamento, a sus consejos, él se separaría de ella, pero nunca la ultrajaría ni de hecho ni de palabra.

Claro es que a su lado su compañera goza de toda cuanta libertad puede gozarse en esta sociedad y es suficiente que ella demuestre deseo de separarse de él para que sin otra ceremonia lo hagan, quedando tan amigos como antes de unirse, y no sería de extrañar que después de una separación más o menos larga, volvieran a unirse.

En sociedad, en la calle, jamás fastidia a sus compañeros con cuentos ni botaratadas insulsas, ni con groserías tontas ni cargosas, siendo por lo general serio y formal en su conversación.

En sus relaciones de amistad con las compañeras de sus camaradas, o con las hijas de los mismos, nunca las molestará con arrumiacas ni dicharachos, pues él considera ( $\mathrm{y}$ tal creo yo también) que las mujeres no necesitamos almibarados y tontos galanteos, pues teniendo como tenemos cerebro y corazón, bien podemos hacer lo que hacen los hombres, que ciertamente no aguardan para sentir amor y pensar, a que nosotras les arrastremos el ala, y en cuanto a la diferencia de sexo, la considera un simple detalle, necesario a la perpetuación y mejoramiento de las razas humanas.

Tal es, mis queridos amigos, el compañero que sin necesidad de terceros, he elegido, sin otra ceremonia que el mutuo consentimiento, sellado por un ósculo de cariñoso y puro afecto, que él ha impreso con amorosa e infinita ternura en mi marchita y pálida frente.

Vosotras lo conocéis, ¿sabéis quién es? ¡El Anarquista!

Decidme ahora, obreras y obreros todos, ¿creéis que yo sea una mala mujer por unirme así, sin curas ni jueces, con un hombre como el que acabo de describiros?

¿Creéis que merezco que arrojéis lodo a mi frente porque confiada y cariñosa todo lo arrastro por el cariño y felicidad del que amo y me ama?

¿Cuál es la cosa mejor de la existencia?

Amar, ¿verdad? Y iqué es mejor, amar por deber, por obligación o por simpatía y atracción?

Pepita Gherra

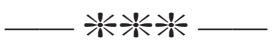

\section{LOS REYES}

Ninguno con su parte se contenta:

Si al uno nombran Rey todos los otros Mejor derecho que el nombrado alegan.

Promete cada cual mejores leyes

Al pueblo y en edén tornar su tierra:

Cree el pueblo sus palabras, se levanta.

Y mejorar creyendo, se degüella.

Vence y queda uno solo; sube al trono.

Pero pobre de gentes y de rentas.

Vuelva a pedir al pueblo oro y soldados.

Para poder cumplirle sus promesas.

Vuelve el pueblo a doblar sus donativos

Cuanto más da oro y sangre, más se merma.

No puede el Rey cumplir, muere y sus

Vuelven a mejorar a la pelea. 
Es la historia de pueblos y de Reyes Desde Adán hasta hoy: tras cada guerra Quedan siempre peor los pobres pueblos. $\mathrm{Y}$ a pesar de todo no escarmientan.

¿Hay remedio ? No sé; si lo hay, no toca Buscarle y señalarle a los poetas.

Que en la historia de pueblos y de Reyes No hacemos más q' cantar lo que otros [cuentan.

Los poetas son átomos sonoros Que con el viento de su siglo ruedan: Más a la edad futura de su siglo La queja y el cantar escritas legan.

\section{类㗭}

Es una cosa menos terrible ser mordido por un endemoniado que sentir el aguijón de la pobreza: un mordisco es pasajero, se cura; en tanto que la pobreza, más cruel que una bestia feroz, más ardiente que el fuego, os desgarra y abrasa sin cesar. Ved ahí el concepto que uno debe formarse de los ricos y de los avaros. Ellos son ladrones, salteadores de caminos que roban a los viajeros y hacen de sus habitaciones cavernas donde entierran los bienes robados...

J. C.

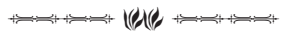

\section{¡BIENVENIDA!}

La carta que va a leerse da a conocer claramente que a pesar de todo aún hay seres que si bien viven rodeados de influencias perniciosas, no están del todo contaminados por ellas.

El alma (llamamos alma al conjunto de sentimientos) se ahoga entre tanto cieno y tiende a elevarse a regiones algo más puras, más gratas.

El pensamiento no hallando expansión ni vuelo entre el fárrago increíble de lo que se llama conveniencias, que no son otra cosa que preocupaciones, busca también más amplios horizontes, espacios y perspectivas más en concordancia con las afecciones que toda persona no corrupta alberga en su corazón.

Hoy en esta sociedad se ven, se presencian escenas, hechos, cuadros que hieren de una manera fuerte e imborrable nuestra mente, impresionándonos tan fuertemente que nos obligan a pesar nuestro a reflexionar, a meditar sobre ellas, y de ahí ese estado especial de nuestro ánimo, esa especie de disgusto y descontento que se apodera de nuestra humanidad psíquica o pensante.

Si la preocupación es muy grande, vence la estupidez, si por el contrario es mayor, la fuerza de razón; entonces sucede lo que en el caso de la compañera que nos escribe, se lucha, se vence y se surge a luz una nueva vida, en ella se encuentran más puras sensaciones, más, más amplias mirajes y mejores perspectivas.

He aquí la carta:

Señoras redactoras de LA VOz DE LA MUjer

Señoras mías: He leído varios números de vuestro periódico, y sintiéndome sumamente conmovida por vuestra decisión y arrojo, y orgullosa a la vez, con mi manera de pensar, pues ya veo que no soy sola, deseo me manden el periódico a la dirección abajo indicada, y contar desde ya con lo poco que mi humilde y aún joven persona pueda seros útil. 
Nada sé, concretamente, de los ideales redentores que propagáis en vuestra franca publicación; pero dueña yo de una imaginación por demás pensante y ansiosa de analizar las causas que producen los malos efectos de que está infectado el mundo, entreveo en vuestros escritos, los mismos pensamientos que embargan mi desorientada mente, y los cuales siempre han quedado por solucionar, hasta que después de leer vuestro periódico, he podido conseguir en parte lo que tantos ratos de sueño me ha quitado y embargado mi mente en los ratos de soledad.

Dispensadme, queridas señoras, por lo tosco e inconveniente de mi estilo, pero no puedo por menos que demostraros mi eterna simpatía. Que no se olviden mandar el periódico a Carmen Díaz, para entregar a María Villa, Rua do Livramento núm. 110, en Río de Janeiro.

Adjunto y remito un peso para ayudar al periódico y se despide de Uds., deseándoles larga vida para bien de la humanidad su S. S.

\section{Maria Villa}

Rio Janeiro, setiembre-96

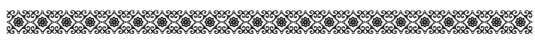

\section{¡JIRONES!...}

Finalizaba el mes de diciembre y con él el año 1880; año que cual todos los que hubo antes y después, fue fecundo en miserias y desgraciados acontecimientos, no para la política o ciertas patrias, mas sí para la clase obrera de todo el globo, la cual vio (según el uso y costumbre desde que hay gobierno) aumentarse sus impuestos, las contribuciones, el número de senadores y diputados (los cuales se multiplican como la hierba mala) y por ende la miseria, el hambre y los padecimientos y también el ejército y la escuadra.

Era la hora del amanecer. El astro Rey, que, como tal, es perezoso, caminaba ese día con sobrada lentitud, a causa tal vez de lo frío y destemplado de la mañana, pues era de ésas que ponen en estado lamentable la nariz y orejas de los que sin capa, guantes y otros excesos se ven obligados por la necesidad a andar por esas calles de... piedra.

Con todo de ser aquella mañana de las más frías que he pasado, habíame yo salido a distraer mi lánguida tristeza, o mejor dicho a aumentarla, pues tal fue lo que conseguí, aun cuando no era ése mi propósito; paseando según acostumbro cuando estoy de mal humor, que es casi siempre.

Con paso lento y maquinal me dirigía no sé por qué calle hacia no recuerdo qué sitio (detalles exactos), pensativa y cabizbaja, semi-pegada a la pared, con el solo objeto de evitar encuentros y dicharachos, lo cual no conseguía, pues parece ser que los señores del sexo barbudo no se creen tales si no dicen al pasar al lado de una mujer alguna de esas frases estúpidas que constituyen el manoseado repertorio (vocabulario diría Gallini) callejero, del arte de... pavear.

Caminaba como digo al azar y sin rumbo fijo, cuando de pronto llamó mi atención un envoltorio, algo así 
como un paquete de ropas, que yacía en el umbral de una casa de lujosa apariencia y señorial aspecto.

Inclinéme con presteza, ardiendo en deseos de saber qué era lo que aquel paquete o envoltorio contenía, y figuraos cuál sería mi sorpresa cuando al descubrir un fino lienzo que lo cubría, me hallé con una carita fría y amoratada.

¡Era un recién nacido!

¡Hijo de mi alma! -exclamé-, sin poder contener mi emoción, cómo es posible que haya seres tan desnaturalizados que... mas no, me interrumpí, calle la torpe lengua, ¿quién sabe con cuánto dolor, con qué angustioso pesar se determinó la madre de este niño a abandonarlo de tal modo?...

Palpitante de emoción, con el corazón henchido de triste dulzura arropé contra mi seno a aquel inocente pequeñuelo y lo llevé a mi desmantelado hogar. Una vez en él lo desenvolví y al hacerlo pude ver que era una niña, ipobre ser!, su boquita entreabierta buscaba con afán una fuente de vida en que nutrirse y al no hallarla, prorrumpió en lastimoso llanto.

¡Ay! aquel llanto resuena aún a través de dieciséis años sin cesar en mis oídos y constituye uno de mis más tristes y dolorosos recuerdos.

¡Imagen de aquella niña, huérfana del cariño de sus padres y sin un ser que se interesase por su suerte, es mi mártir corazón que solo, aislado y sin consuelo, arrostró entre la tenebrosa oscuridad de la noche de mis días, huérfano del cariño y del placer como nave, que combatida sin cesar por el desatado y violento vendaval, desarbolada y sin timón, no halla puerto en que guare- cerse! ¡Ay de mí! la sorda tempestad de mis dolores ¿cuándo tendrá fin?...

$$
\begin{gathered}
* \\
* \quad *
\end{gathered}
$$

Al desenvolver las ropas de aquel ser, trozo de carne humana palpitante, modelado con las líneas más puras de la belleza femenina, hallé una carta que entre otras cosas decía:

..."sin embargo, sin valor para soportar el escarnio, los insultos y la rechifla del mundo, véome obligada a abandonarla, ipobre hija mía! al azar del mundo impío, mas sepa quien recoja este harapo de carne tibia y sonrosada, que no es hija del vicio ni de la corrupción".

"No, hija mía, hija del amor más puro y noble, más inmenso y grande, quiso tu suerte desdichada privarte antes de nacer del que te acogería como hija, y si yo te abandono es porque el mundo me niega el derecho de sentirme orgullosa de ser tu madre ipor qué? porque mis amores no estaban legalizados", ¡como si el amor precisara más sanción que la del corazón de los que se aman!

"Mis padres, ancianos ya, morirían de vergüenza y morirían maldiciéndome si supieran que yo, yo su única y querida hija, los había deshonrado y antes que tal suceda prefiero sufrir yo sola, aunque mi corazón se rasgue en jirones."

...después de estos párrafos hacía toda clase de recomendaciones, rogando a la persona que recogiera a su hija que le pusiera el nombre de Miriam y que la cuidara y quisiera como a hija propia.

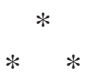


Dieciséis años estuvo a mi lado, yo la amaba como amara a una hija, si la tuviera.

Desgraciadamente yo no era aún Anarquista, así que temiendo fuera víctima de un engaño, era excesivamente rigurosa con ella en lo que se refería a relaciones amorosas, rigor que dio por resultado precisamente lo que más temía, esto es, fue madre sin ser esposa.

Seducida por un capataz de una fábrica que aún hoy existe, pues de esto apenas hace 10 meses, fue abandonada por él cuando estaba próxima a ser madre, y para huir de mi cólera fue a ocultar su falta en un hospital y cuando pasado el período de la convalecencia buscó trabajo y se convenció de que en ninguna parte obtendría lo suficiente para pagar la lactancia de su niña (pues era una niña, según me lo dijo en su última carta) y cubrir sus necesidades, no halló más camino que el de la prostitución.

He aquí la carta en que me manifestaba su resolución, dice así:

"Querida madre: (1)

"Olvida para siempre, joh, madre mía! que tienes en el mundo una hija; haz de cuenta que no existe ya, que ha muerto.

"Amaba y era amada, sí, era amada, y es por esto que a pesar de tu vigilancia, a pesar de tus cuidados me entregué en brazos del objeto de mi amor. No era casada, bien lo sabía, mas yo ignoraba que sin ese requisito no se podía amar. Además, si el

(1) Conviene advertir que ella ignoraba las circunstancias de su nacimiento. que hoy me abandona lo hace así, es indudable que lo hace porque ya no me ama, y si esto es así, es mil veces preferible no haberse casado, porque imagínate cuál sería el tormento de mi vida al verme sujeta y unida para siempre a un hombre que no me amara y al cual, como es lógico suponer, también dejaría de amar yo más tarde o más temprano, puesto que quien ama pide ternuras y arrullos y quien no ama da disgustos y palos muchas veces, dado que vive disgustado y contra su voluntad. Por todo lo cual prefiero no ser casada y ser libre.

"A ti, querida madre te extrañará sin duda la lógica glacial de mis palabras, pero dejarán ellas de extrañarte al decirte que esto me lo enseñó una compañera de cama en el hospital (a que fui a dar a luz).

"Si no me presento a ti es por temor a tus justas reconvenciones, pues a pesar de todo, tú creerás que he deshonrado tus canas y enlodado tu honor, y más que todo por evitarte la vergüenza que las murmuraciones respecto de mi conducta te ocasionaría. Sin mi presencia podrás evitarla.

"Madre querida, tengo una niña, una hija, ¿comprendes? a la que amo como tú me amabas a mí, como aman las madres y convencida que con mi trabajo jamás podría ganar lo suficiente para criarla y atender a mis necesidades; a causa de lo mezquino de los salarios, he tomado la resolución de vender mi cuerpo... no maldigas madre mía al saber que el cuerpo de tu hija, este cuerpo que tú has cuidado con tanto esmero, no será de hoy en adelante otra cosa que carne que se vende al peso... y si hay algo que pue- 
da hacer que me perdones, sea el saber que si yo me prostituyo, lo hago por no abandonar a mi hija, a quien amo tanto, que por ella no retrocedo ante nada, ni nada me aterra.

"Madre, mis labios aún no han sido manchados con contactos impuros, antes que tal suceda, recibe de ellos un beso de amor, de veneración y paz de tu desgraciada

Hija"

A pesar de esta carta (cuyo valor moral recién hoy comprendo, que yo rasgué bullente en ira), yo maldije mil y mil veces aquella joven infeliz.

Un mes más tarde supe que víctima del cieno del torrente y consumida por la tisis, había fallecido en el duro lecho del hospital de mujeres, a los pocos días de su caída y maldiciendo sin cesar la suerte impía a que la sociedad le había arrojado.

En cuanto a su hija, jamás supe nada de ella.

Todo cuanto pude saber fue el lugar do reposan los restos de aquella mártir y que destrozados por el bisturí del anatómico, fueron la mofa y el objeto de las risotadas de los practicantes que rodeaban la mesa en que se verificó la autopsia.

Aquellos restos tan sin compasión destrozados, reposan en un lugar apartado, en la necrópolis llamada Chacarita, y en una modesta y sencilla tumba a donde los hice trasladar, y al borde de la cual voy siempre que puedo, a llevar la cariñosa ofrenda de frescas flores con que la riego, tumba que no tiene loza ni inscripción alguna, pues ¿qué más loza que mi cora- zón, ni qué mejor inscripción que mi memoria?

En puridad jóvenes, hombres, todos cuantos insultáis a la ramera, cuál fue más noble de las dos madres, la que abandonó a su hija para salvarse, o la que por salvar a su hija sucumbió.

$\mathrm{Y}$ vosotras, queridas niñas que sentís asco y desprecio por esas infelices mujeres, ¿habéis comprendido por qué se cae?

¡Oh, tened corazón! no insultéis a la mujer caída, jella es la mártir de esta sociedad!

¿Qué será de la hija de Miriam? ¡tal vez mañana será carne que se venda al peso!

Cuando tal pienso no puedo menos de maldecirme a mí y maldecir la sociedad y el mundo en el cual los nobles y puros corazones son constreñidos y arrojados al fango del torrente por la inicua maldad de la canalla del guante y la levita.

¿A qué admirarse, pues, que corazones ardientes y generosos traten de derrumbar por cualquier medio y a toda costa tan perniciosas instituciones?

Francamente os digo que se precisa ser un malvado para estar conforme con las bases anti-naturales de esta corrupta y malsana sociedad.

El cauterio por el fuego es el temperamento a seguir con un miembro gangrenado.

Cautericemos, pues.

Vuestra

Pepita GHerra

Marzo 30 de 1896. 


\section{Mesa revuelta

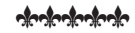

\section{Leemos en "La Vanguardia":}

Programa ANÁRQuico - Es muy difícil dar con el anarquismo-tino [sic], porque cada anarquista guarda en su pequeño cacumen un plan de sociedad futura y ve y aprecia las cosas de una manera propia y diferente a la de los demás.

Pero, ¡ahora sí que lo encontramos! En forma de programa acaban de darlo a luz los periodiquitos costeados, según ellos mismos, por borrachos, idiotas, asesinos y frailes y burgueses.

Hay en el nuevo credo anárquico artículo como éste:

"Nos proponemos sustituir la actual organización del Estado autoritario por las relaciones administrativas de los trabajadores, federados por libre pacto y en libres asociaciones sobre la base de la producción del cambio y del consumo, esto es, la Anarquía."

De anárquico sólo tiene esto algunas palabras huecas y frases de doble sentido que no pueden oscurecer su fondo netamente socialista.

¿Qué les parece a los compañeros? ¿En dónde habrán leído esos imbéciles eso?

Si serán alcornoques, llamar programa anárquico a algunas palabras huecas y frases de doble sentido, cuyo fondo es netamente socialista.

¿Cómo puede ser programa anárquico lo que es idea socialista?

¡Cuanto siete cane caro patroni!

Leemos en "La Prensa" - En el Departamento 9 de La Pampa, la mujer Manuela Bermúdez asesinó alevosamente a su esposo, Juan Cutiellos de 45 años, y a sus hijos, Artemio y Manuela, de 7 y 3 años, respectivamente.

Causa del crimen. La vida insoportable que Cutiellos daba a su esposa.

Comentarios de La Prensa: Que caiga todo el rigor de la ley contra esa esposa infame y madre sin entrañas.

A las compañeras que nos han enviado trabajos para publicar pedimos disculpa hasta el número próximo.

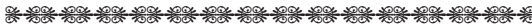

\section{AVISO}

Ponemos en conocimiento de los compañeros en general que la Redacción y Administración de este periódico a contar del presente número, está a cargo de un nuevo grupo, el cual se propone no omitir esfuerzo alguno para la buena marcha de LA Voz de la Mujer.

Avisamos también que el estado de la Administración al recibir nosotras el periódico era:

Déficit de núm. 6 $\$ 10.47$

Deuda a "La Revolución social" \$1.50

Suma

Para cubrir este déficit nos fue entregada una lista que publicamos bajo el rubro Lista A, cuyo importe suma $\$ 8.80$ los que descontados de los 11 pesos 97 cts. dejan un déficit total de \$3.17

Tal era el estado administrativo de LA Voz de LA Mujer al hacernos cargo de ella.

Os saluda fraternalmente.

\section{La Redacción y Administración}

Según puede verse examinando la lista del núm. 6 el déficit que por error se dijo ser de 5.17, era de 10.17 . 
Los compañeros que tengan algo que reclamar pueden dirigirse a nosotras. Casilla de correo núm. 1277.

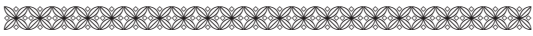

\section{SUSCRIPCIÓN \\ PARA \\ LA VOZ DE LA MUJER}

Lista A - Un Manchelli 0.40, Un anarquista célebre 0.50 , Una mujer que es desgraciada por causa de la honra 0.30 , Un avisado 0.10, Un garbanzo 0.10, Varios tipógrafos 0.90, Desgraciado 0.20, Otro 0.20 , Un grupo de Anarquistas 2.50, Nunca la humanidad gozará 0.40 , de fraternidad ni armonía 0.40, mientras no lleguemos a implantar 0.40, el libre estado de anarquía 0.40 , autoridad y libertad son contrarias 0.30 , vale más un caballo domado que un hombre por instruir 0.30, Amor libre 0.50, Libertad para todos 0.20. - Suma 8.80.

Nota - Esta lista que nos fue entregada por la administración anterior no tiene nada que ver con las que a continuación publicamos.

De Villa Constitución:

Un Manchego 0.50, Cañones 1.00, Rompe cabezas 0.40 , Una joven que ya no se pone polvos 0.20 , Un barbero 0.20, Sobrante de muchas rutinas 1.00 - Suma 3.00

LISTA N ${ }^{\circ} 7$ - Uno que no M 0.20, No ponga nada 0.10 , Soy desgraciado 0.50 , Un cigarrero pobre 0.10 , No pongas nada 0.10 , Uno que no tiene más 0.10 , Un cigarrero revolucionario 0.30 , Un cigarrero 0.10 , Uno que nada 0.20 , Grupo Juventud Unida 2.75 - Suma pesos 4.35.

Por conducto de la compañera Luisa Priani - María C. 0.60, Marino C. 0.30, Adela T. 0.05, Juana la hermosa 0.10, Ignacio el loco 0.50 , Una triste 0.20 , Vir- ginia la modista 0.20 , Guido el desertor 0.20 , Juan C. dice que es un desgraciado 0.20 , Una niña que estudia 0.20 , Un joven enamorado de Clementina E. 0.20, Isabel le gustan los jóvenes anarquistas 0.10, Busco a Úrsula y no la encuentro 0.10 , Teresita la rubia enamorada 0.10 , El joven Eleodoro Valdés enamorado de la señorita María C. 0.20, Un lustrador que quiere lustrar con sangre burguesa 0.20 , Un mercero que por fiar está desesperado 0.20 , Una joven que pronto se va a matar con la pesada cadena del matrimonio 0.10 , ¡Ay ! qué día dichoso fue cuando por primera vez mis ojos se encontraron con una joven vestida con traje negro 0.20 , Un mercante de burros burgueses 0.20 , Soy un pobre infeliz 0.10 , La fuga de Amelia muchos anarquistas han llorado 0.50, Adiós mi patria 0.03.

Suma 4.25

De varios - Llamé 0.20, N. N. 0.20, Pepita Guerra 0.30, Grupo Juventud Unida 1.20, Uno por Ravachol 0.25, por conducto de "La Questione Sociale": Un descalzo 0.10, Uno que quiere justicia 0.10, José Carvanales 0.50, Augusto Masse 0.25, A. D. Belgrano 0.50 - Suma 3.70.

LISTA $\mathrm{N}^{\circ} 8$ - Fuego y exterminio 0.50 , B. O. 0.20, Manuel B. 0.20, Luis Costa 0.20, Posadios 0.40, T. H. 0.20, El patrón de un despacho de bebidas 0.50 , Resto de una convidada 0.10 , Sobrante de tranway 0.10, Sobraron 0.20, M. Cristóbal Uribe 1.00, de la Lista núm. 3: 0.05. Suma 1.75.

LISTA N ${ }^{\circ} 4-$ M. 0.10, C. 0.10, T. 0.10, A. 0.10, Grupo Juventud Unida 0.50.

LISTA $N^{\circ} 5$ - Una compañera revolucionaria blanca 0.30 , Un empleado del gobierno que se rebela 0.30 , Un empleado de la aduana 0.30 , Farahon 0.50. LISTA 22 sobrantes de copas 0.50 , Un cigarrero sin cigarros 0.20 , mármol por un zapatero 0.50 
+ 0.10. LISTA N ${ }^{\circ}$ 27: E. D. L. 0.20, un Ruh 0.10 , sobrante de una convidada 0.05 , I. C. 0.05, I. M. 0.50, Mi Madre 0.20. Suma 4.70.

GRUPO "LOS ÁCRATAS" - Pietro 0.50 , Un sastre explotado 0.50 , Serviago 0.50 , Un tendero $1.00, \mathrm{~B}$. Oreste 0.20 , ex Fraile 0.20 , Un zapatero 0.20 , Un rebelde 0.20 , Guerra y exterminio 0.30 , Un intangible 0.20, Un Vengeur 0.20, Mezza Anarchia 0.20, Ripposo 0.20, G. A. 59 0.50, Umberto rey de los otros animales 0.30 , Yo 0.05 .

Suma 5.20
Total recolectado

30.00

Gastos: por 2.000 ejemplares

de núm. 7

40.00

Gastos de correo

8.85

Déficit del núm. 6

3.17

Suma

52.02

Déficit de este número

22.00

Nota: Rogamos a las compañeras que nos remitan antes de 15 días las listas de suscripción. 


\section{LA VOZ DE LA MUJER}

Aparece cuando puede

y por suscripción voluntaria

Periódico Comunista-Anárquico

Dirección: A. BARCLA

Casilla Correo 1277 - Capital

\section{Resúrjam...}

Hemos sido agradablemente sorprendidas por la lectura de un manifiesto titulado "La esclavitud en Buenos Aires y Montevideo" y sobre el cual no podemos menos de hacer algunas reflexiones.

Hay en el aludido manifiesto párrafos tan expresivos como éstos:

"Donde no pudo alcanzar ninguna autoridad para reprimir la esclavitud de mujeres, muy bien lo pueden unas 150 infelices, que por muchos años vivieron esclavizadas, que fueron explotadas en el modo más bárbaro y echadas a la calle como se echan las cosas inservibles.

"Son 150 ex esclavas que hoy se coaligan para desenmascarar a sus verdugos; para acusarlos ante el Supremo Tribunal de la conciencia pública; para hacerlos aborrecer y maldecir de toda persona que comprenda ser una ignominia sin igual, dejar que se esclavicen tantas criaturas humanas a la fin de un siglo como el actual."

¿Qué tal? ¿qué decís de esto los que os asustáis cuando os decimos que no hace falta gobierno alguno?

Es una bella y sencilla lección.

Las autoridades y el gobierno nada pudieron ni se preocuparían de hacer aunque pudieran. Pero lo que ellos no pudieron hacer lo hace la "libre iniciativa" de 150 mujeres, que pudieran ser menos o más según la obra que se propusieran llevar a cabo.
Ya veréis como ahora el gobierno intervendrá ¿sabéis para qué? pues muy sencillo: para cobrar un derecho por poner un letrero o chapa con el nombre de la sociedad. Es decir, para entorpecer y poner cortapisas a la acción de la asociación.

Vamos por partes.

Dice el manifiesto: "La esclavitud de Buenos Aires y Montevideo".

Decimos nosotras: ¿Creen las asociadas y defensoras de esas infelices que solamente aquí y en Montevideo existe esa y otras esclavitudes?

¡Oh, no, no creáis eso, compañeras!

Desde allá del ancho Tíber, al turbulento Plata, de allá de las gigantes cumbres del legendario Cáucaso hasta las colosales cimas del Andes aterrador; del uno al otro Polo, por la ancha faz del mundo, dueña y señora de la raza infeliz obrera reina la esclavitud. ¡Esclavitud más negra, más infamante y dura, horrenda esclavitud que nos tortura, que nos desgarra el cuerpo, que nos oprime el alma, la esclavitud degradante del salario!

Noches de duelo, lágrimas de sangre abrasadoras; visión fatal, noches de insomnio, negras, jay! muy negras pusiéronme a las puertas siempre abiertas de esa mansión de lágrimas y duelo, recinto de placer para el potente!

Mi madre, la noble mártir del trabajo, en cama, en el triste lecho del dolor; mi padre, sin ocupación; mis tiernos hermanitos : ipan, Pepita, pan! ¿por qué no nos das pan? ¿No ves qué 
buenos somos? ¡Pan!.. bullente en ira, hermanos míos, ¡pan!.. gritaba yo con ansia loca. ¿En dónde hallarlo? En la panadería, Pepita, sí que hay, si yo lo he visto, ¿quieres que vaya? Sí, verás que vengo pronto, que no tardo, que no me quedo a jugar, ¡no, te lo juro!

Así decían. Y yo, lívido el rostro, la mirada incierta, oprimido el corazón con ansia loca, mis sienes golpeando, salí con un mar de delirios en la frente, la muerte en los ojos y en el alma ¿quién sabe que llevaba yo en el alma?

Tenía quince años, era esbelta, acaso un tanto hermosa ¡caballero, por Dios, una limosna!..

- Hermosa chica a fe, vale la pena.

- ¡Vaya si la vale!..

- ¡Por Dios, no, querida, pues yo la conozco, ni verla ni hablarle puedo; mas no importa, por ti te la daré, a quien por cierto miro y te confieso que te encuentro bella!...

Impuro beso soñó... sentí un zarpazo... un ¡ay! desgarrador rompió el silencio de la noche umbría, que salió de mi garganta enronquecida... luego una estridente carcajada, pasos después... y luego nada.

Corrí despavorida, descompuesta la faz, desencajada...

- No traes pan, me dijo el mayorcito.

- No la había, mi bien, hasta mañana, dije procurando serenarme y en voz alta y luego a su oído. No lo pidas, por Dios, que no hay di... ne... ro, dije prorrumpiendo en lloro, bañando mi frente con mis lágrimas.

- ¿Te acuerdas, madre amada, y tú, mi gallardo Raúl, te acuerdas? ¿Verdad que sí? ¡Tenías ya diez años!...

Después... después... tengo ver- güenza en deciros compañeras, cual se baja... ¡dejad que lo guarde aquí en mi pecho y que llore a ver si eso me calma!

Sigamos recortando:

"Si la policía de Montevideo siguiera el noble ejemplo de la de esta capital, ¡oh!, entonces los Caftens se verían cerradas todas las puertas por donde introducen aquí su mercadería; mas según parece a las autoridades policiales de Montevideo poco les importa que se introduzcan allá mujeres para mercadearlas, pues hasta hoy las solicitudes que enviamos a aquella Jefatura en el sentido de apoyar nuestra misión, han quedado en letra muerta.

"Una vez que las mujeres importadas llegan a desembarcar en Montevideo y pasar en los Depósitos, es sumamente difícil saber de cuál parte llegarán a Buenos Aires, porque para realizar esto, los sitios y los modos son muchos y diferentes.

"Ciérrese a los esclavizadores el puerto de Montevideo, como aquí se les cerró la Dársena y entonces si quieren importar mujeres en la América del Sur no les quedará otro modo que servirse de globos aerostáticos."

¡Llamáis noble al proceder de la policía de Buenos Aires! Si supierais que ella sabía hace mucho lo que pasaba... Si supierais que ella compartía con los infames "Caftens" la ruin ganancia del comercio de esa carne humana!

¿Olvidáis acaso las libretas y otros cobros impuestos que mi pluma se resiste a escribir? Malhaya la raza ruin de comerciantes de nuestra carne, hermanas...

En cuanto a la policía de Montevideo, ¿qué le importa a ella? ¿Le daríais vosotros la ganancia que de esas infelices sacan? 
La de aquí (no os asombréis) proseguirá sacándola.

¡Cerrar el puerto de Montevideo y las Dársenas de Buenos Aires!...

Cerrad la miseria, compañeras, y habránse cerrado de doquier las playas.

Pero entretanto, jay de la raza infeliz de obreras! jay de las pobres proletarias!

En suma: Una asociación de bravas, pero aún no bien conscientes compañeras que por LIBRE Y ESPONTÁNEA INICIATIVA sale a luchar en defensa de las víctimas de una clase de esclavitud. ¡Ay! jexisten tantas!

Pero al fin es moverse, es luchar y eso es vida, es tener un pensamiento, un ideal y cuando vemos tantas que viven sin pensar en nada.

Otros párrafos:

"Estamos dispuestas a hacer cualquier sacrificio para seguir resueltas y llenas de entusiasmo en la santa misión que nos impusimos. Ningún obstáculo nos detendrá en nuestro escabroso camino. Si nos harán falta las fuerzas caeremos heroicamente como soldado sobre el campo de batalla, si nos harán falta los recursos después de haber vendido hasta el último trapo, iremos pidiendo limosna en nombre de la humanidad y de la Religión ultrajadas!”

Mucho nos gusta ese ánimo, mucho, pero ya lo veis, tendréis que vender hasta el último trapo, y quién sabe si aún así ganáis.

Vender los trapos, ¡hermanas queridas!

¿Y decís que lucháis en nombre de la Religión ultrajada? Craso error, queridas, en nombre de vuestros corazones generosos sí, pero jamás en el de esa religión que en tanto que voso- tras estáis dispuestas a vender vuestras ropas para salvar de la esclavitud, de la prostitución a vuestras compañeras, ella guarda por doquier y en todas partes encerradas, deslumbrantes y espléndidas riquezas, tesoros de valor incalculable, y su jefe, el santo padre trece, ¡once mil habitaciones tiene para sólo su regalo en el palacio en Roma!

¡En nombre de una religión que os dice, no os acariciéis, oh jóvenes que amáis, sin antes casaros, ni os casaré si no pagáis!

¡En nombre de una religión que desprecia a la mujer caída, y que en Roma, la ciudad de sus afanes, comerciaba también con vuestros cuerpos, pues cuatrocientos prostíbulos oficiales, de los cuales el religioso padre santo sacaba un beneficio líquido de trescientas mil liras anuales!!

¡Oh, no digáis tal, que tiembla el labio, late el corazón apresurado y trémula la mano se levanta, buscando un santo rostro en que descargar la desbordante ira de nuestros corazones!

Para terminar, copiamos la carta que una vez enteradas del manifiesto aludido enviamos, dice:

Buenos Aires, noviembre 1896.

A la Sociedad Deutscher Frauen Verein ¡Salud y libertad!

Queridas hermanas:

Hemos sido agradablemente sorprendidas por vuestro Boletín $\mathrm{N}^{\circ} 1$, es decir sorprendidas por la iniciativa que habéis tomado, porque en cuanto a la esclavitud ya sabíamos que existía.

Como quiera que nosotras también luchamos por la libertad, no sólo de nuestras defendidas, sino de toda la cla- 
se obrera, no sólo en defensa de las que como carne de matadero son traídas a estas playas por una clase de explotadores, sino en defensa de nosotras mismas y de todos los esclavos y en lucha contra toda clase de opresores, hemos recibido con simpatía vuestra idea.

El fin que os proponéis es noble, a no dudarlo, mas cada cual según sus necesidades; nosotras miramos más lejos, no nos concretamos a combatir a una sola clase de esclavitud; estamos contra todas.

Consideramos que los efectos tienen sus causas y que es a estas últimas a quien hay que atacar cuando los efectos son malos.

¿Cuál es la causa de que nuestras infelices protegidas lleguen a estas playas para ser sumidas en el horrendo recinto del prostíbulo?

¿Por qué abandonarán sus hogares, sus padres, sus amigas, sus hermanas y su amor acaso?

Por la miseria, sin duda, pues si tuvieran lo suficiente para vivir en su país natal es indudable que no lo abandonarían para venir a estas apartadas regiones en demanda de pan ¡Triste pitanza!

Luego, pues, la miseria es causa de su desgracia.

Veamos ahora cuál es la causa de la miseria, no de ellas sólo, sino de todos los obreros del mundo entero.

¿Queréis que se lo preguntemos a los que poseyendo miles de millones tienen a bien traficar con el hambre, el trabajo y la sangre del obrero?

Tened en cuenta, hermanas, que los agobiantes impuestos y la despiadada sed de oro de los acaparadores de la tierra y los comerciantes en general, tanto el que por vivir él cómodamente os aumenta el precio de la casa u os vende más caro el pan, mermando de tal modo los productos y el salario del trabajador, que obliga a éstos a permitir que sus jóvenes y hermosas hijas abandonen sus paternos lares y vengan o vayan al prostíbulo. Luego tenemos causa de la prostitución: la miseria; causa de la miseria, la explotación, y esto no sólo sucede en la secular Europa, en todas partes pasa.

Aquí en la culta Buenos Aires, como la llamáis vosotras, sucumben miles de jóvenes, unas en el taller, otras en su hogar, por exceso de trabajo y falta de alimento, y otras en los prostíbulos, y en los hospitales miles.

$\mathrm{Y}$ esto sucede con proletarias nacidas en la misma culta Buenos Aires, porque habéis de saber que para el obrero no hay más patria ni más gloria ni más nada que el taller, el prostíbulo o la cárcel.

Cuando una persona está obligada a vender sus fuerzas o su cuerpo a un patrón, no es libre en modo alguno, no ser libre es ser esclavo; por librarnos de toda clase de esclavitud lucharemos.

Vosotras lo hacéis sólo por una.

Mas no importa, os aplaudimos.

Eso decía la carta y que os desea emancipación y cariño dice

Pepita Gherra

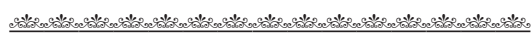

\section{1 de noviembre de 1887}

Fecha que hace nueve años quedó grabada en el corazón de todos los que aspiran a mejorar la triste condición 
del esclavo moderno, en que están sumidos todos los obreros.

El crimen jurídico llevado a cabo en Chicago el día 11 de noviembre DE 1887 por la sanguinaria burguesía norteamericana, de acuerdo con las teorías de la de todos los demás países, no se borrará jamás de nuestra mente.

$\mathrm{Ni}$ se borrará tampoco el de la burguesía española, que no queriendo ser menos cruel, la siguió después levantando por segunda vez el patíbulo en Jerez. Monarquía española, República (modelo) americana: diferentes nombres e idénticos procedimientos. Y esto es todo.

Pero no importa; los mártires que sucumben no mueren para la posteridad; que si en la cruz se admira la abnegación del mártir del Gólgota, bien puede ser el cadalso símbolo de redención.

Y no por esto creas bestial burguesía que nos resignamos a ser los mártires de siempre, no; que nuestro más anhelante deseo es acelerar el día de las venganzas, para recordaros por última vez las víctimas propiciatorias de vuestros crímenes y maldades.

Creísteis dar fin de una idea redentora asesinando a sus propagandistas, y ya lo veis, de las cenizas de los muertos se levantan millares que la propagan y que os maldicen.

¡Seguid, seguid exterminando a hombres de ideas libertarias, que la misma humanidad se encargará de darles vida en los que nacen!

Sólo conseguiréis con vuestros instintos feroces que nosotros, los de la plebe ignorante y baja, vayamos acumulando día por día en nuestros lacerados corazones el odio reconcentra- do y profundo hacia todo cuanto nos esclaviza y humilla, por vosotros creado. Es lo que nos habéis enseñado: un camino de luto y sangre para no saber más que odiaros cuando recordamos a los heroicos mártires del trabajo, de la guillotina y del tablado.

M.

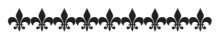 \\ A las madres \\ ... Y a ti principalmente, madre mía.}

Disculpadme queridas lectoras, si sólo sé decir cosas tristes hoy; mas iqué queréis?; veo ante mí cosas tan tristes, sufre tanto mi corazón, son tan dolorosos mis pensamientos, que hasta las vibraciones de mis sensaciones son tristes.

Tal vez que la mayoría de vosotras sonreiréis compasivamente al leer estas líneas y, no obstante, creedlo, mientras las estoy trazando apresuradamente hago esfuerzos por contener las lágrimas rebeldes que pugnan por salir de mis hinchados párpados...

¿Sabéis por qué? porque estoy pensando en vuestros inocentes pequeñuelos, en vuestros queridos niños.

¿Cuánto los amáis, verdad? ¡Cuán inocentes y hermosos son! ¿Qué de inefables goces os producen sus caricias, sus besos e infantiles gracias!

¡Qué dicha es ser madre! ¡Qué inmensa ventura hay en poder estrechar contra nuestro seno a ese pequeño ser a quien por no tener en nuestro idioma mezquino frase más expresiva, llamamos hijo!

¡Flores, pájaros y niños, poseeros y poseer el dulce e inolvidable objeto de 
un perdido e inolvidable amor, he ahí toda cuanta felicidad buscara yo en el mundo!

Dulce y triste es para mí el ver la juventud naciente, es decir la infancia. La vista de un niño regocija mi corazón por un momento, porque amo la niñez, mas no puedo tampoco ver un niño sin que mi corazón se oprima y lo sienta dolorido, hinchado de amargura.

Cuando lo miro risueño y sonrosado venir a mi regazo, lo beso y colmo de caricias y todo cuanto puedo hacer para hacerle reír y gozar me parece poco, porque veo enfrente a él un porvenir no seguro y cierto, no risueño y sonrosado, sino oscuro, muy oscuro; incierto, muy incierto; lleno de padecimientos, de luchas, de miserias, de tristezas y de dolorosos pesares. ¡Tiemblo por su suerte!

Si se enferma jay! su pobre madre no podrá proporcionarles un buen médico; ¡cobran tan caro! jsomos tan pobres los pobres!

Cuando tenga la edad de comenzar a estudiar, ¿podrá hacerlo? quién sabe, ¡son tan escasos los salarios! tal vez tendrá que comenzar a trabajar para ayudar con sus pequeños bracitos a sostener las necesidades del hogar.

Irá a una fábrica, a un taller ¡cuánto lo temo! ¡los capataces son tan duros de corazón! ¡son tan poco compasivos! ¡abusan tanto de los niños! A mí me pegaban mucho cuando siendo niña (no tenía aún 12 años) trabajaba en una pequeña cárcel, en donde se fabricaban camisetas.

Conservo aún en la cara la cicatriz de un golpe que se me aplicó porque en un descuido quemé una manga de una camiseta cuyo valor era de un peso y veinte, importe que se me descontó de mi salario, que era de noventa centavos diarios. ¡Una cicatriz de una herida por la cual manó abundantemente la sangre, como si todo el oro, como si todas las riquezas del mundo valieran una sola gota de sangre obrera!

¡Temo también que el exceso de trabajo, lo malsano de los talleres, lo poco nutritivo del alimento, hagan palidecer, primero las mejillas, hoy sonrosadas, de vuestros hijos y después languidecer, enflaquecer y tornar anémicos, enjutos y tal vez tísicos los cuerpecitos de esos lindos pequeñuelos!

Después temo, si son todos varones, que la patria los mande a luchar, a exponer sus vidas, a morir quizá destrozados por un feroz balazo en su rubia cabellera, cuya frente tersa sombrea hoy los revueltos bucles de su cabello; o que con las carnes desgarradas, cubierto de lodo sangriento y pisoteado acaso por los herrados cascos de los corceles del enemigo, exhale el postrer suspiro, solo y abandonado en un campo de batalla, lejos, muy lejos de vosotras, joh, madres!

También temo que un día carezca de pan, de hogar, de amor y de amigos; que en vano busque trabajo y no lo halle en parte alguna... ¡Qué será de él entonces! ¡Ah! ¡no me lo preguntéis, no quiero, no, no quiero pensarlo, tengo miedo de hacerlo!...

Si es niña, joh! entonces, mi temor se torna en angustia, mi tristeza en horrible inquietud, la fábrica, el taller, el capataz, las insinuaciones arteras del dueño o amo, la amenaza de las despedidas si no se accede a ciertas vilezas, y allá en lontananza, donde el 
aire se hace más espeso, la atmósfera más insalubre, el pan más negro, la noche más oscura, la vida más pesada y las lágrimas más amargas, ¡la tétrica mansión de las caídas!

Después la cárcel, el hospital, el asilo, el anfiteatro, la infamante autopsia, las carcajadas soeces, las risotadas impuras de los practicantes y luego la tumba, la nada y sobre ella, la eterna y estridente carcajada de los satisfechos, el lúgubre tañir de las campanas, el lúgubre redoble del tambor, el seco batir del paño de la pasiva bandera que el viento agita, el rodar presuroso de los lujosos carruajes del señor, y el eco impuro de la impura orgía de los impuros reyezuelos del trabajo...

¡Cuánta infamia! Por eso el mecer de la cuna de los niños, sus alegres sonrisas, sus infantiles palmoteos, sus tiernas e inocentes caricias, llenan mi pensamiento de amargura, embargan mi corazón de tristeza, inundan de lágrimas mis ojos.

Vosotras ¡oh, madres! que amáis a vuestros pequeñuelos, ¿no habéis jamás pensado en el incierto porvenir que les aguarda?

Es muy triste creerlo, y, sin embargo, ese porvenir podría ser risueño y bello si vosotras los quisierais como los quiero yo.

Meditad en el medio mejor de hacer más risueño el porvenir de nuestros niños. No penséis más como antes en "eso está muy lejos" "yo no lo he de ver".

¿Y vuestros hijos? ¡Oh madres!... ¿Y vuestras niñas?..

¡Amadlos! ¡no seáis egoístas! ¡tened corazón!

Pepita Gherra

\section{El grito de la plebe}

क

(Esta composición será recitada en la velada que se celebrará el 15 del corriente en la "Unión Obrera Española", Chacabuco 661.)

¡Henos aquí por fin! ¡Por fin llegamos! ¿Sabéis quién somos?

¡La inúmera falange de proscriptos!... Que llega con fúnebre alarido

A pagaros la cuenta de delitos

En que la habéis sumido,

Sin otro crimen ni pecados,

Que aquel de haber nacido

En choza ruin desheredados!...

¡Henos aquí por fin! ¡oh raza envilecida!

De vuestro alcázar en las puertas golpeando:

¿Sabéis quién somos? ¡La plebe maldecida!

La que pasó llorando

Hasta hoy, los días de su amarga vida.

¡La inmunda y baja plebe! que arrojada

Del mundo todo, y por todo escarnecida, Ya de gemir y de llorar hastiada

De Caín a la raza encanallada

¡Viene a saldar la cuenta prometida!...

Los hijos somos del trabajo ingrato

Que vagando sin pan y sin hogares...

Y sin paternos lares...

Y sin amor... sin nada...

Amargo llanto a mares

Triste y sin consuelo derramaba.

Hasta que atronando

Los montes y la sierra

De gozo palpitando

Cual eco del averno

Oímos el clarín, ronco de guerra

Con que nos fue llamando

Y los odios recordando

De los caínes de la tierra

Abortos del infierno

Allá detrás los mares

La voz de las venganzas seculares...

Oído habemos como hambrienta flora

Que llegar mira la presa que acechaba

La señal que anunciaba 
Que llegado era.

Y cogiendo el puñal de las venganzas

Y la humeante tea:

Henos aquí, que a cobrar venimos

Gota por gota la sangre que vertimos.

¡Sabed, pues! ¡sabed a qué venimos!

A sacaros la sangre de las venas

Para lavar con ella aquestos signos

Señales de cadenas

Que ahora con pesar ceñimos.

¡De nuestro mal y duelo

De siglos os debemos larga cuenta!

Mas ... ;alegraos! que al fin permite el cielo

Pagaros una a una tanta afrenta.

Cuando la voz del exterminio oímos

Retumbar por los ámbitos del mundo

¿Sabéis dónde estábamos?

¡Del lupanar en el recinto inmundo

Algunos llorábamos!

En horrendas prisiones a millares

$\mathrm{Y}$ de miles a cientos en destierro

Arrastrando por ajeno yerro

La cadena de odios seculares!

Hicisteis de nosotros,

Porque a vuestra maldad así le plugo,

Ya el reo, ya el verdugo,

Ya el ladrón, ya el suicida,

¡Parias sempiternos de la vida!

¡En vano fue implorar,

Gemir en vano!

¡Cuán caro ha de pagar

Su inicuo proceder el vil tirano!.

Ya más el llanto a mares

No derramamos tristes,

Ya más ante el señor nos humillamos

Ya más no le imploramos

Ya más no somos lo que otra vez fuimos,

$¡ Y$ si en son de venganza nos venimos,

Vosotros lo quisisteis!

Esta, esta herida, ¡mirad!

Qué negra sangre aún brota,

¡Mirad! Traemos rota

Y cubierta con polvo del camino

La burda vestimenta

Del paria peregrino

Proscripto de la vida

E impreso en nuestra frente el negro sino
De vuestra negra afrenta!...

¡Mirad nuestras mujeres,

Cual las llamáis vosotros!

¡Miradlas! Traen rotos

De la pureza los cendales todos,

Que blancos cual armiño

Y bellos cual de un niño

La sonrisa primera

Manchasteis con el lodo

Con que en vuestros placeres

¡Lo salpicabais todo!...

Mirad esta ramera

Que maldijisteis un día,

Contra ella del desprecio

Lanzando el rígido anatema

De flor perfumada que antes era

De fuerza y amor viviente emblema,

De vil pitanza el precio

Le disteis en la orgía

Para dejarla en el siguiente día

Del lupanar inmundo

En los negros dinteles arrojada,

Acompañando su dolor profundo

Con torpe carcajada.

Mirad nuestras hermanas

Que a igual de nuestras hijas

De puras, gentiles y hechiceras,

Tomasteis en livianas

Corruptas y lúbricas rameras

E inicuas y viles cortesanas.

¡Nuestros hijos mirad, pálidos, débiles!

Minados por la lepra cancerosa

De infamante y corrupta podredumbre

Adquirida en presidios o cuarteles

A donde, crueles

Los llevasteis a infame servidumbre,

¡Raza impura, odiosa, raza maldita!

¡Ved en sus frentes pálidas escrita

La huella sin igual del sodomita!

¡Todo esto os lo debemos!...

¡Noches de dolor, males sin tasa...

Tantos ¡ay! que la memoria escasa

A todos recordar ya no podemos!...

Vano es el lamento y vano el ruego,

Pues nuestro mal al recordar prolijos,

Jurado hemos por Luzbel que el mismo

[fuego 
Abrasará a los padres y a los hijos... ¿Por qué lloráis? ¡Miserables! ¿Os aterra

Del corazón nuestro la dureza impía?

Acordaos ¡oh fieras! que en fraternal guerra,

A ser así nos enseñasteis un día...

Tal siempre nos habéis tratado,

Ya veis, pues que no hemos despreciado

La enseñanza ruin que prodigado

Nos habéis en asilos y cuarteles.

¿Qué más queréis? ¿No somos cual vosotros

Malvados y crueles

De alma y corazón podridos, rotos?

No lloréis, pues, que es vil quien se [acobarda

De sus acciones al ver el resultado;

Después de tantos cual habéis matado,

No es tan mala la suerte que os aguardo.

No de horrendo cadalso en el tablado...

Sangriento moriréis:

Ni del lúgubre tambor el destemplado...

Parche batirán

Ni las aves agoreras del pecado...

Sus cantos alzarán.

No tendréis de los pesados grillos...

El peso que arrostrar.

$\mathrm{Ni}$ tendréis que pasar

La postrera noche en la agonía...

¡No por vida mía!

Y reparad que es suerte

Tener como tendréis en vuestra muerte...

Mil rojas llamaradas

Y en vez de triste lloro

Un numeroso coro

De argentinas y alegres carcajadas...

¡No tendréis de soldados ni jueces

La caterva sanguinaria y dura

Que os haga apurar hasta las heces,

El cáliz de amargura!

Con qué placer pisamos

De vuestro alcázar dorado los dinteles

¡A Abridnos! ¡voto al diablo! ¡u os abrasamos

Cual hacías ayer con los infieles!

No tiembles ¡oh raza de caínes!

Morid como matabais en antaño

Y no como rebaño

De avejuelas ruines.

¿Vuestras hembras? ¡No! Ésas se quedan
Nuestro sueño a arrullar de vencedores,

Y con voces que a la música remedan,

La canción a entonar de los amores.

¿Creéis que no? También amar

[sabemos

Y gozar, y beber ardientes en la orgía

Del deleite la mágica ambrosía

Y besar en el alma si queremos.

También amar sabemos y sentir.

También nosotros hemos

Ilusiones forjado de oro y rosa,

De nácar y zafir...

¡Ea! ¡Buenas mozas! no pálidas se tornen

Con miedo torpe las róseas facciones.

Enjugad ese llanto,

Que tenemos aquí hartos llorones,

Permutad por las risas ese lloro

Y entonad al amor dulces canciones...

No imitéis ¡vive Dios! a esos varones

Que miráis de rodillas

Entonando preces y oraciones

Cual débiles chiquillas...

Sed vosotras fuertes y animosas

Si cautivar queréis nuestro albedrío,

Que no sienta bien, creedlo, a las hermosas

Sus ojos convertir en fuente o río.

No lloréis pues: Vosotras sois ardientes

Y hombres precisáis, no zahumerios;

hombres varoniles y potentes

Que os den de placer undosos ríos.

¡También!... ¡También en antaño!

Nuestros padres tristísimos lloraban,

Manando sangre el corazón herido

Y su llanto y su dolor burlaban,

Sus gemidos dolientes despreciando.

También ayer nuestras esposas

A vuestros pies gimiendo se arrastraban

Y de sus ayes de piedad burlaban

Las notas quejumbrosas.

También de nuestras hijas

De sus penas quejándose prolijas,

A vosotras llegó el lamento triste

Pidiendo compasión que no tuviste.

¡Vaya! ¡Camaradas! Se hace tarde,

Ya clarea la aurora en el oriente,

¿No la veis? ¡Mirad! iparece que arde

El trono de algún Dios Omnipotente! 
Cerrad las puertas y aplicad la llama a ver de hacer de modo...

¿Eh? ¿quién llama?

¡Si vuestros hijos también, mujeres todo!

¡Ya no más piedad, vano es el ruego;

Ya de tomar la venganza la hora tarda!

¡Dos teas apliquemos! ¡todo arda!

¡Y al que tenga piedad! ¡ése va al fuego!

Quedemos algunos en la entrada

Nuestro triunfo a mirar alegremente.

¡Uff! ¡en marcha los demás! que ya se siente

El hedor de la carne calcinada.

Pepita Gherra

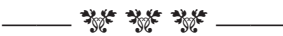

\section{A LA MUJER}

A vosotras, compañeras de trabajo e infortunios, me dirijo, a vosotras que sufrís como yo la doble esclavitud del capital y del hombre.

Algunas de nosotras hemos abrazado el bello ideal anarquista porque comprendemos que sólo con la amplia libertad que ésta proclama, podemos ser felices.

Los hombres todos, proletarios lo mismo que burgueses, y todas las clases dominantes, siempre han tenido a la mujer en la mayor ignorancia para poder así con más facilidad dominarla, ha procurado mantenerla siempre en la esclavitud, y para impedirle que saliera de esta triste condición la ha rodeado de preocupaciones necias; ha menospreciado su trabajo; su influencia en la sociedad y la ha anulado; en la familia la ha postergado al segundo lugar; ha creado el honor para que a la que no quiera ser esclava la sociedad la desprecie.

Estoy segura de que muchas de mis compañeras de infortunio al leer esto dejarán asomar una sonrisa de desdén a sus labios; les parecerá lo que digo un absurdo o simplemente una broma; mas si ellas se detienen a reflexionarlo, entenderán que lo que les digo no es ninguna ilusión mía, sino el reflejo de lo que pasa en la sociedad.

También sé que a la pudiente señora que va al teatro de la Ópera esto le causará risa; es natural, ella aunque tenga que ocultarse, satisface todos sus deseos; tampoco le importa a la honrada matrona esposa del doctor tal o cual, porque ella mientras que aparenta que va a hacer una obra de caridad, aprovecha ese tiempo para hacer lo que la estúpida sociedad burguesa prohíbe.

Si una de nosotras proletarias se entrega a un hombre que ama, es al punto considerada como una prostituta y despreciada hasta por sus mismas compañeras, como si se hubiera degradado, cuando no ha hecho más que seguir los impulsos de su corazón.

En cambio, si un hombre fuese virgen al tálamo nupcial sería despreciado y serviría de risa a sus amigos y a la misma que consideraría deshonra no ser tan virgen ella.

Hasta este extremo ha llegado la estupidez humana; hasta considerar justa, aceptable y buena la ley del embudo.

Nos hacen creer en un Dios Todopoderoso para que por temor a un castigo imaginario no procuremos cambiar de vida; nos dicen que todos somos hijos de Dios, y sin embargo vemos que ese Dios debe ser un padre muy injusto cuando tiene a la inmensa mayoría de sus hijos en la miseria y obligados a trabajar para satisfacer los gustos y los caprichos de los que deberían ser sus hermanos; nos dicen que 
Dios castiga el adulterio, y sin embargo nosotras sabemos que las señoras más encopetadas que como más instruidas deberían conocer más a Dios, son con pocas excepciones las que más engañan a sus maridos, y lo que es más gracioso, los curas, esos humildes ministros de Dios, son los que ellas eligen para satisfacer sus necesidades sexuales. No creáis queridas compañeras que exagero en lo que estoy diciendo, si os es posible, averiguad lo que el señor del Carril hizo con el cura de Belgrano cuando lo encontró con su esposa. Hace poco tiempo fue llevado preso otro cura (también en Belgrano) porque estaba cumpliendo con los preceptos de la ley de Dios.

Todos los hombres: los ricos, los pobres, la señorita high life y la respetable matrona hacen en cuestión de amor lo que quieren, todo está permitido para ellos y nadie osa atacar los derechos adquiridos. Sólo la mujer proletaria es la que está obligada o debe temer las consecuencia de un desliz, porque para ella no habrá perdón; ella debe callar y sufrir; ella debe ir a la fábrica o a la tienda y escuchar con agrado las estupideces que el gomoso y presumido dueño o dependiente le diga; si quiere ser honrada tiene que conformarse con contraer ciertas enfermedades que dañan horriblemente su organismo, tiene que rebelarse contra la naturaleza, porque le han quitado el valor para rebelarse contra la mentira y el crimen.

A nosotras no se nos quiere más que por el provecho que podemos dar, ora satisfaciendo los apetitos de los hombres, ora para que trabajemos sin descanso, sin acordarse jamás de que nosotras también tenemos un corazón capaz de sentir generosos impulsos y una inteligencia que puede concebir y asimilar ideas científicas y nobles.

A la delicada señorita que no tiene que ganarse el pan que lleva a la boca se la aprisiona dulcemente en una dorada jaula. A nosotras brutalmente se nos obliga a seguir la voluntad de otro...

La esposa del burgués puede gozar de las caricias del amor. La del trabajador apenas si tiene tiempo de escuchar los soeces insultos que éste en su desesperación le dirige.

La madre burguesa vive tranquila porque sabe que su hijo tiene un brillante porvenir y no lo matarán en la guerra. La trabajadora, en cambio, puede estar satisfecha porque después de muchos trabajos y privaciones para criar a su hijo, éste será un defensor de la patria... o vivirá como ha vivido ella: en la miseria, en la ignorancia y con la alegre perspectiva de morir en un hospital o en una prisión. Tendrá el inefable consuelo de que si su hijo es soldado y su esposo está en huelga, haga fuego sobre él; en cambio podrá para compensar estos beneficios morirse de hambre sin maldecir a los causantes de su desgracia, porque entonces sería una mala patriota.

Compañeras: puesto que todos van contra nosotras, puesto que sobre nosotras quieren desahogar todos sus iras y hacernos blanco de sus infamias, rebelémonos, pero rebelémonos de una manera enérgica, que no dé pábulo a que nos sigan considerando como seres débiles e incapaces. No besemos más la mano que nos abofetea; no seamos por más tiempo ruines y cobardes; 
sigamos el ejemplo de esos compañeros que supieron arrostrar la muerte por una causa justa.

MarÍa Muñoz

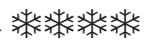

\section{A las proletarias}

Niñas queridas, vosotras que trabajáis tanto un día y otro día, sin más reposo que el estrictamente necesario para no sucumbir a la fatiga, vosotras que amáis a vuestros hermanitos, y, sin embargo, no podéis darle lo que les hace tanta falta: educación, buen alimento, buen vestido, buena ropa, expansión, luz, aire, etc. Vosotras que amáis tanto a vuestros padres y que no obstante los veis que carecen de tantas cosas, vosotras que queréis a vuestras amigas y no obstante, no podéis ayudarlas cuanto y cuando lo necesitan, por qué no parar un instante vuestras labores y meditar en vuestra situación.

Vosotras habéis trabajado siempre ¿no es verdad?

Vuestros padres también, vuestros hermanos igualmente, y decidme: ¿después de tanto trabajar tenéis lo que os hace falta, poseéis y disfrutáis de lo que desearías? No. ¿Verdad?

No, porque vuestras ropas no son tan abrigadas ni de tan buena clase como las necesitaríais, vuestros botines tienen quizás más uso del conveniente, vuestra habitación no es tan cómoda como es de desear, vuestras comidas no son tan sanas, tan nutritivas y tampoco tan abundantes como es preciso.
¿Empleáis, pues, vuestro dinero, de mala manera acaso? ¡Ay, no! Vuestras diversiones son muy escasas, al teatro casi nunca, paseos muy escasos y ésos a pie, lujo ninguno, libros, jay de mí! hasta ni ese pequeño placer de la lectura podéis disfrutar, porque cuestan muy caros los libros. ¿A qué se debe entonces que trabajando tanto disfrutéis tan poco y de tan escasos placeres?

¿Lo sabéis acaso? Tal vez sí, y tal vez no, pero de cualquier modo es mejor que yo os dé mi parecer.

Yo creo que se debe simplemente a que os pagan muy poco por vuestro trabajo y a que os cobran mucho por todo cuanto necesitáis para vivir. ¿Por qué así? Simplemente también porque hay quien os quita una parte, la mayor, no lo dudéis, del producto de vuestro trabajo; ¿quién es el que así os roba, o, mejor dicho, nos roba, porque yo también soy obrera y no hay obrero ni obrera que no sea robado y robada?

Los que viven sin trabajar, es decir, los patrones.

¡Los patrones! ¡los que nada hacen, los que no trabajan! iy ellos no obstante disfrutan de todas cuantas comodidades pueden proporcionar la civilización y el progreso moderno! ¡Qué injusticia!...

$$
\begin{gathered}
* \\
* \quad *
\end{gathered}
$$

Yo bien sé que vosotras diréis que los patrones trabajan, que sacan cuentas, que cuidan los talleres, que dan órdenes, que llevan los libros, que vigilan sus operarios, etcétera.

Pero decidme, ¿si vosotras os ponéis por ejemplo a sacar muchas cuentas en 
vuestra casa, a dar muchas órdenes y a vigilar mucho a vuestros hermanos, al fin del día qué producto habréis presentado ante la vista de los demás, de vuestro trabajo? Ninguno, unos cuantos garabatos en un papel y esto es todo, las órdenes se habrán perdido en el aire, en cuanto a la vigilancia, ésa hay que tomarla de una pata para que no escape. Tal vez vuestros pequeños hermanos habrán trabajado más, pero lo que es vosotras ¿qué habéis hecho? Nada, simplemente.

(Continuará)

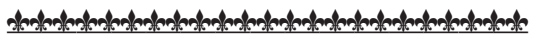

\section{iA TI:}

¡Oh mi dulce y tierno amado! ¡Oh mi sin par Patroni, luz y alegría en estas regiones! ¡De mi herido pecho la triste queja escucha, y di después si es poco el mal que me habedes fecho tú y los tuyos con las vuesas entuertas!,..

Escucha:

"Es el caso que en Gante existe desde hace muchos años una poderosa organización cooperativa del partido obrero, titulada Vooruit (en castellano adelante) con un periódico que lleva el mismo título, órgano principal del partido socialista belga, fundado y dirigido todo por el señor Anseele, actualmente diputado socialista en el parlamento belga.

"Pero los regeneradores de la sociedad han ido todavía más lejos de lo que iría cualquier aborrecido patrón en el camino de la iniquidad. Como el Vooruit además de ser una empresa industrial cooperativa es también una empresa política, esta providencia de los obreros les retenía parte de sus salarios para formar un fondo que servía a ir procurando mandatos electorales a unos cuantos protegidos por el sumo pontífice de la asociación, a enviar fondos a Holanda para sostener huelgas, y a otros fines igualmente útiles y provechosos para los obreros de Gante.

"Por las revelaciones del ciudadano De Witte hemos sabido que las obreras que confeccionan las camisas para la sociedad cooperativa, sufren un descuento de 5 céntimos sobre los 23 céntimos de franco que perciben por cada camisa.

"Sobre estos 5 céntimos, que representan cerca del $25 \%$, se aplican 3 céntimos al material y 2 a la caja llamada de resistencia, es decir que una buena obrera, capaz de hacer por ejemplo cuatro camisas por día, no gana en todo sino frs. 0.92 , sobre cuyo miserable salario, además del descuento por material (12 céntimos), se le descuenta cerca del 10\% para alimentar la caja de los ciudadanos que se dedican a la política, quedando su salario reducido a la ridícula suma de 72 céntimos de franco!

"En Gante ha tenido lugar una reunión general de la sociedad, donde se han discutido acaloradamente esos hechos, se han oído las quejas de los obreros, y la defensa de Anseele, quien, para imitar en todo a esos vampiros de patrones, ha rehusado terminantemente comunicar a los socios los libros de la sociedad, a fin de que nadie conozca el empleo de los fondos sociales.

"Como se ve, para una vez que los socialistas se meten a industriales, lo hacen casi tan bien como esos mons- 
truos de industriales que se usan en la podrida sociedad en que vivimos.

"¿Qué digo tan bien! mucho mejor se han conducido según las declaraciones que las obreras han hecho, pues una de ellas, la propia hija del mismísimo editor del Vooruit, ha declarado que allí reina un despotismo intolerable, y cuenta una escena en que Anseele, dirigiéndose a un grupo de muchachas en que ella se encontraba, las insultó en términos tan groseros que no pueden traducirse en las columnas de un periódico decente.

"Éstas y otras muchas cosas por el estilo ha dicho el ciudadano De Witte en otro periódico socialista titulado Recht voor Allen (derechos para todos), en donde se hace constar que las obreras del Vooruit saldrían gustosísimas de allí, si encontraran trabajo en otra parte.

"Hay más todavía; uno de los miembros del comité investigador ha protestado en un periódico de que se haya puesto su firma en el informe presentado por ésta, añadiendo que él no ha intervenido en nada y no tiene conocimiento de nada." (La Nación).

¡Oh modernos cataplasmáticos regeneradores, qué bien lo hacéis! ¡Risueñas esperanzas nos dais, oh politicastros trasnochados! ¡Oh congresiles de deshora! ¡Oh lechuzones de la R. S.!

Dios sea con vosotras, y la santísima Virgen María os tenga de su mano. ¡Amén!

\section{MESA REVUELTA}

Aclaración- En nuestro número pasado y en la Sección Notas hubimos de salir un tanto mal paradas (sin culpa nuestra por cierto) a causa de que en la imprenta suprimieran, sin avisarnos, parte de las notas por exceso de material, según se nos dijo cuando ya el periódico estaba impreso.

Por tal causa una crítica que hacíamos de la estupidez de las "van-gardes", más que tal pareció ser todo lo contrario.

En fin, que nuestra "Mesa Revuelta", fue "Mesa Macana".

Disculpen los compañeros.

El domingo 15 del corriente a las 8 y media de la noche tendrá lugar la velada que celebrará la Sociedad "Libre de Declamación” con el siguiente

\section{PROGRAMA}

Primera Parte - I $^{\circ}$ Visione, monólogo de F.V. - $2^{\circ}$ Le steppe della Siberia, poesía de Maradi.

Segunda Parte - $3^{\circ}$ Maggio, boceto de P. Gori.

Tercera Parte - $4^{\circ}$ L'Emigrante e la Patria, poesía de L. Tavani. - $5^{\circ}$ El Grito de la Plebe, monólogo de Pepita Guerra.

Cuarta Parte - $6^{\circ}$ Moralismo, diálogo de F. V. - $7^{\circ}$ Il canto della fame, poesía de F. Vezzani. $8^{\circ}$ L'Inno dei lavoratori.

Quinta Parte - $9^{\circ}$ Conferenza

Entrada con asiento 50 centavos.

Perfectamente convencidos de que además de los muchos paquetes que se nos han devuelto, muchos otros se extraviarán, pedimos a todos cuantos quieran recibir nuestra hoja, nos envíen su dirección, indicando el número de ejemplares que necesiten. 
Según carta que hemos recibido de Lisboa, los compañeros del Brasil que han sido deportados, ya llegaron al lugar que los verdugos de aquella joven república les destinaron. ¡Ánimo camaradas!

Hemos recibido el folleto "A os Jovens" de nuestro camarada Kropotkine. Está traducido al idioma portugués y fue publicado por la "Biblioteca Literaria" de Porto (Portugal).

También hemos recibido y lo ponemos a disposición de los compañeros "La Nueva Esclavitud" por John Davis, miembro del Congreso de los E. Unidos, publicado por el grupo "Centro de Propaganda Obrera" de Tampa (Florida). Es muy interesante y merece leerse. Precio: Cada cual sus fuerzas.

Se nos comunica: Un grupo cómicodramático denominado "José Zorrilla" está ensayando el notable drama literario "El Pan del Pobre".

Los compañeros que quieran cooperar al buen resultado de esta iniciativa, pueden dirigirse a A. Barcla, casilla de correo núm. 1277.

Buen éxito les deseamos nosotras.

Al compañero Socratidión: Disculpa compañero que no publiquemos la tuya, pues a causa del retraso en la salida del periódico, ha perdido su oportunidad. Esperamos no te disgustarás y que seguirás enviándonos otras.

Al Productor: Recibimos folletos, envíos. Si podéis enviad más "Sociologías". Enviaremos el producto enseguida que lo recojamos.

Del grupo "Los Ácratas" de Barra- cas, se nos comunica que tienen iniciada una suscripción voluntaria para hacer imprimir el folleto de propaganda anárquica "Entre Campesinos", lo que ponemos en conocimiento de los compañeros para que apoyen a dicho grupo, los que simpaticen con dicha iniciativa. Dirigirse a la casilla de correo 1277, LA Voz de la Mujer.

Nuestro querido colega "El Productor" nos ha enviado un paquete de "Sociologías", "Entre campesinos" y "Consecuencias"

El producto que den estos folletos lo destinamos a "El Productor". Quedan, pues, a disposición de los compañeros "Sociología Anarquista" al precio de 50 cts., "Entre Campesinos" a 20 y "Consecuencias" a 5.

Quedan avisados los compañeros.

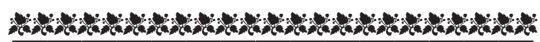

\section{Suscripción voluntaria \\ PARA EL NÚM. 8 DE \\ LA VOZ DE LA MUJER}

\section{Capital}

Lista núm. 54 - Grupo Antorcha del Progreso

Vaillant 0.50 pesos, Me he olvidado dardo 0.15, Un oprimido A. J. 0.15, Un amante de la vida 0.20 , Uno que ha estado un mes sin pagar alquiler 0.20, Querer es poder 1, Acracia García 0.60, Un burro 0.10 , R. S. 0.20 , Un compañero 0.20, N. A. 0.50 - Total 3.80 - Para La Anarquía 1.65 - Quedan para La Voz de la Mujer 2.15.

Lista Núm. 9 - G. C. 0.10 pesos, Un carrero 0.20, Greco 0.20, "Zena" 0.20, Magdalena 0.20 , J. M. Rey 0.10, Un desgraciatto 0.50, Amor libre 0.20, Hijo de la Anarquía 
0.10, Rosita 0.10, Expulsión del Gefe 0.10, Sobrante de copas 0.40 - Total 2.40 .

Lista núm. 58 - A. C. 0.20, S. G. 0.40, A. J. 0.10 - Total 0.70 .

Lista núm. 68 - Fuego y exterminio 0.25, Martínez Campos 0.50 - Total 0.75.

Lista núm. 60 - Brazo roto por patria 0.20 , J. Espinosa 0.50, ¡A Abajo los patriotas! 0.25, Un fulero X 0.10 - Total 1.05 .

Lista núm. 6 - D. G. 0.60 pesos, Un cochero 0.15, Un émulo de Valero 0.10, Un émulo de Vico 0.10 - Total 0.95 . (Esta lista es del núm. 7 de LA Voz DE LA Mujer y no se publicó por olvido.)

Lista núm. 25 - Uno desde la cama 0.02, Un Yankee 0.05, Cualquier cosa 0.10, Un cigarrero revolucionario 0.20 , Cualquiera 0.05 , Un cigarrero revolucionario 0.08 , Una cocherita 0.25 - Total 0.75

Grupo Juventud Unida

Papa in Roma 0.10 pesos, Un anarquista nuevo 0.30, José Bruneti 0.10, Luis XV 0.30, Un oriental gallego 0.50, Una aparadora intransigente 0.15 , Juan José 0.10 , Paquita 0.20 , Sobrante de una discusión de Socialismo 0.30, Josefa la costurera 0.10, Pepita Gómez 0.10, Pepita la modista 0.10 , Juana la gallega 0.10 , Un rayo 0.10 , Un zapatero descalzco 0.10, Un paisano de Pallás 0.10, Un anarquista 0.20, Sangre y exterminio 0.10 , Una que escupe sangre 0.10, T. H. 0.20, Antonia Méndez 0.20, Andrea 0.10, Una aparadora 0.10, Una escoba de Burgueses 0.10, Qué importa 0.10, Un zapatero descalzo 0.10, F. G. 0.45, Catalina 0.10, Inés al faro 0.20, Adelante con la lucha 0.30, Estudioso 0.25, Viva la Anarquía 0.15, T. H. 0.50 - Total 6.

Lista núm. 55 - Grupo Los Ácratas

Del cuero de perro 0.10 pesos, Un huelguista 0.05 , Un amante de la verdad 1, Libertad 0.40, Lo que reclamó Cabello 2, Una desheredada 0.25 , J. A. 0.25, Un fondista 0.25 , A. J. 0.20, Un atorrante 0.10 , De los alpargateros 1 , Del tranway 0.05 - Total 5.45.

Varios - No pongas nada 0.40 pesos,
Pedro Roca 0.10, Dos cigarreros 0.20, Un socialista 0.10, Un gironedela 0.50, L. G. 0.20, Nada 0.10, Claro 0.50, Lacour 8, Una mujer 2, Pepita 3, J. M. 0.50, Tú 0.10 - Total 15.40 .

\section{INTERIOR}

De Mar del Plata - Por conducto de La Revolución Social - Un idealista 0.30.

De Villa Constitución: Lista núm. 16.

Candelario 0.20, Una andaluza 0.10, Una joven que pensaba que los anarquistas eran otra cosa 0.20 , Una loca 0.15 , Otra que vive a disgusto 0.25 , Un anarquista 0.10 , Uno que le falta un capital para salir el más célebre del mundo 0.50 , El que escribe 0.50. Por conducto de A. - Muerte a Patroni 0.50, Uno que manja caña 0.25, Viva la libertad 0.25. Total 4.39.

\section{EXTERIOR}

De Rio Janeiro - María Villa pesos 1.

De Montevideo - Un panadero catalán y un compañero 4 pesos, Mesina Maestrini 1, Una Austríaca 1 .

Total moneda argentina 7 pesos

RESUMEN

Recibido: De la Capital $\$ 34.60$

Interior

Exterior

$\$ 7.00$

Total

$\$ 45.90$

Gastos : Por 2000 ejemp.

de este núm.

$\$ 40.00$

De Correo

$\$ 8.00$

Déficit anterior

$\$ 21.98$

Total

$\$ 69.98$

Déficit actual

$\$ 24.08$

Se ruega a los compañeros devolver las listas antes de los 15 días.

La Redacción 


\section{LA VOZ DE LA MUJER}

Aparece cuando puede

y por suscripción voluntaria
Periódico Comunista-Anárquico
Dirección: A. BARCLA

Casilla Correo 1277 - Capital

\section{¿ANTE EL CADALSO...:}

(1)

¡Sí, ante el cadalso, en que los eunucos de las fieras encumbradas van a servirles con su legendaria mansedumbre la sangrienta ración de carne humana, venimos a alzar nuestra voz de protesta, nosotros los malditos de la vida, nosotros los proscritos del placer, nosotros los rebeldes sempiternos!

La sanguinaria burguesía de España ha querido demostrar al mundo entero lo que valen para ellos las libertades de los pueblos, y he aquí cómo lo ha hecho. Historiemos: somos enemigos de las guerras, porque comprendemos que la única víctima de ellas es el pueblo. ¡Siempre el pueblo! Por eso cuando en España se anunció que iba a ser enviada a Cuba una remesa de (50.000) cincuenta mil obreros (usando la libertad de pensamiento) nos preparábamos por medio de periódicos, de reuniones y folletos, a hacer propaganda entre el pueblo para que éste se negara a ir a Cuba a morir como los perros.

Comprendió el gobierno que si nos dejaba libres para hacer tal propaganda, ningún soldado iría, dado lo cansado que estaba el pueblo, que empieza a comprender al fin que sólo tiene patria cuando se trata de morir por ella; y entonces el gobierno buscó el medio de impedir nuestro deseo.

No atreviéndose a prendernos sin ningún pretexto, por el mal efecto que el conocimiento de la verdad haría al pueblo, imaginó un medio por el cual apareciera obrando con razón y con derecho, y he aquí cuál fue ese medio: Con uno de sus esbirros secretos mandó arrojar una bomba en la calle Cambios Nuevos (en Barcelona), en el momento en que pasaba una procesión religiosa y el resultado fue perfecto.

El pobre pueblo cree, porque ellos se cuidan de hacérselo creer así, que los anarquistas tienen por único ideal la explosión, el incendio y el degüello; así que no le costó trabajo creer que los anarquistas eran los que habían hecho aquello.

Sirviéndoles la bomba de pretexto, se prendió en montón a los que se pudo, y los que no fueron presos, huyeron.

Se los sometió a tribunales militares porque no tenían confianza en los civiles e hicieron que los debates del proceso fueran secretos, porque temían que el pueblo sospechara el pasteleo. Entre tanto salió la expedición de los soldados.

Del proceso salieron condenados veintiocho anarquistas a muerte, y los demás hasta llegar a ciento, se los condenó al presidio y a trabajos forzados a perpetuo. ¡Y ahí tienen los obreros satisfecho al gobierno! Resultó sin embargo que el pueblo de Barcelona y el de España entero se encontraba disgustado con aquella masacre de anarquistas, y entonces se apeló al consabido medio: se arrojó otra bomba en uno de los barrios más céntricos y, es claro, 
renació la indignación del pueblo y juzgó que aquella masacre era justa y volvió todo a la calma; y para mostrar que era magnánimo el gobierno, en vez de veintiocho se conformó con masacrar a ocho, condenando a los demás a presidio perpetuo. Ésta es la historia de los hechos. Pero aun suponiendo que fuera obra de los anarquistas la bomba arrojada en Cambios Nuevos icreen por ventura los obreros que se precisa para arrojarla ochenta y siete de nuestros compañeros? Huelga la contestación. Lo que hay es que se teme a nuestras ideas y es a ellas a quien se quiere destruir. No se nos odia por nuestros hechos, sino por nuestras teorías.

Jamás hemos negado la paternidad de nuestros hechos, ni tampoco queremos negar que estamos conformes con las bombas y con otros procedimientos, porque comprendemos que la rebelión de hechos es la que puede como en todos tiempos en la lucha [...] [una y] mil veces, odiamos a muerte a los tiranos y para combatirlos [todos los medios] nos parecen buenos y más desde que vemos los que con nosotros usan ellos. Ni libertad de pensar ni de escribir, ni de hablar ni de reunirse, de nada en fin, ninguna nos quieren conceder; bien hayan pues las explosiones para hacer comprender a los tiranos y a sus sostenedores que no estamos dispuestos a cejar en nuestro empeño.

$\mathrm{Y}$ a aquellos que nos acusan de que también matamos inocentes con nuestras explosiones, contestamos: lo sentimos; no es sin dolor que procedemos así, mas la ley de Darwin se impone, somos los malditos; desde el último polizonte hasta el obrero estúpido, todos son contra nosotros; desde el más tonto socialista hasta el más encumbrado burgués, todos nos odian, ¿qué hemos de hacer pues, sino odiar? Y no obstante no odiamos, bien claro lo dicen los periódicos, folletos, etc., que a costa de miles sacrificios estamos editando continuamente y con peligro de nuestra libertad y hasta de nuestra vida, pues esos mismos obreros a quienes dedicamos nuestros esfuerzos son los primeros que nos traicionan cuando pueden, dada su estúpida ceguera. No obstante nosotros no por eso los odiamos, los compadecemos y si alguno cae bajo los golpes de nuestra cólera vengadora, lo repetimos, somos los primeros en sentirlo, mas no por eso vamos a sacrificar por ellos nuestra vida.

Por otra parte, los burgueses no vengan, al matarnos, la vida de esos que caen, porque si así fuera ¿quién matará al juez que basándose en su creencia y en su código condena a muerte a un semejante? Nosotros también nos basamos en nuestras creencias. ¿Quién juzgará al general que sacrifica miles de hombres en un día en un campo de batalla? ¿Y al gobierno que manda a esos generales? ¡Es fuerza que esto concluya y ha de concluir, nosotros lo queremos y será! Conste, no obstante, que a nosotros los anarquistas se nos odia más por nuestras ideas que por nuestros hechos.

Sí, nuestra idea de paz, todo armonía; esa idea de amor, todo cariño que rechaza todo lo malo y lo podrido; sí, esa idea, símbolo de libertad y de igualdad amada, esa bella anarquía lisonjera, esperanza del que sufre, ésa es la que temen y odian, la que quieren destruir. 
No por dar torpe expansión a nuestro odio ni por lamentar con vanas quejas las infamias que sobre nosotros pesan, es que venimos a protestar; venimos para afianzar una vez más ante los soberbios potentados de la altura que ni tememos sus infamias, ni sus venganzas nos aterran. Es para esto que venimos a alzar nuestra voz de protesta. Venimos para decirles que la tempestad que la encumbrada canalla europea descargó de nuestros hermanos en las cabezas altaneras ¡ni nos intimida ni acobarda, ni doblar hace las nuestras! ¡Que si como sangriento guante de pelea nos arroja ocho cabezas de anarquistas, nosotros, la canalla despreciable, cual nos apellidan ellos, el guante presurosos recogemos para ir pronto al desafío!

Sí, ante el cadalso lo repetimos. ¡Cual siempre en la brecha, seguiremos siendo indomables luchadores a quien nada detiene, a quien nadie intimida! ¡Sí , seguiremos cual siempre siendo la bélica falange arrolladora, que no en lejano día, empujada por la fuerza incontrastable de los hechos y por la ley del progreso poderoso, traspasando las líneas del cadalso, vendrá a exterminarte, ¡oh, burguesía! en tus propias madrigueras, en tus baluartes!

¡Hijos del dolor y la miseria, la miseria y el dolor han de empujarnos! ¡Queréis sofocar nuestras ideas! ¡Inútil pretender el que os afana!

La anarquía por ley natural surgió al mundo y por ley natural sigue en su curso. En la moderna ciencia, en la filosofía, halló su cuna y la ciencia y el progreso son su ayuda y la miseria, el "ya estaba escrito” que la ayuda. ¡Derramad nuestra sangre cuanto podáis, mas cuidad no os ahoguéis en ella!
Nuestra idea es el raudal tranquilo, que serpenteando por el bosque enmarañado de la vida atraviesa valles y colinas para ir a, cual arroyuelo plateado, a fecundar la yerma pradera. ¡Oponedle obstáculos y vallas y en torrente asolador se trueca!

Habéis chapuceado el límpido raudal de nuestra secular paciencia y hoy os disgusta el ver que revuelto se desliza.

Nuestra vieja estupidez mofasteis, insultando a vuestro antojo la doliente queja de nuestro duelo y de nuestra miseria: ¡buscado habéis con torpe y brutal mano el blanco cendal de nuestros inocentes sentimientos, nos hicisteis sufrir lo indecible, nuestro corazón habéis obscurecido entregándonos al turbulento mar de la miseria, donde inciertos vagábamos sin hoy y sin mañana, sin pan y sin amor, sin nada!...

Nos hablasteis de la ley del fuerte y hoy que la aceptamos os espantáis ¡cobardes!...

Hoy que la muchedumbre de los hambrientados en la negra tiniebla se prepara, azuzando sus odios vengadores, a lanzar contra vosotros las bélicas falanges de sus innumerables legiones, os espantáis ¡oh viles! ¡Humanicidas cobardes que esgrimiendo de un código infernal la ley tirana, obscurecéis con los vapores de la sangre proletaria los limpios arreboles del mañana! ¡Mas no importa, proseguid como queráis; no está lejano el día en que surgiendo del fondo del abismo de miserias en que le habéis sumido, desborden con horrendo paroxismo las legiones de esclavos de la tierra y semejando a fantasmas del infierno, abortos de impiedad, ebrios de odio, 
revolviendo en las órbitas hundidas sanguínea la pupila de abrasante mirada, ardiendo en sed de sangre y de matanza, hambrientos, traspasarán las lindes del cadalso, y cual si fueran rugientes aquilones que la espantosa tempestad traía con su crujiente látigo hostigara, agitando allá en lo alto los desgarrados girones de su rojo estandarte de pelea, recorriendo como avalancha formidable la faz inmensa del planeta Tierra, arrasarán los templos y palacios, limpiando de tiranos y de jueces, de frailes y canallas y de todos los infames que hoy la pueblan!

Entonces, ésos que hoy son vuestro baluarte, sangrienta fuerza de vuestra fuerza ¡oh burguesía! pagarán con creces esta deuda. La pagaréis joh policías, frailes y jueces! ¡La pagaréis en la ocasión primera! ¿No oís de todos los hogares del trabajador que en la miseria vive, alzarse la protesta de la próxima tormenta precursora? Pues bien: ese sordo clamor del oprimido, más terrible en su aparente calma os anuncia jvampiros insaciables! que se acerca la hora de justicia. Entonces jay! de vosotros, cuál serán vanos vuestros códigos, vuestros verdugos y jueces vanos. Y... después por las amplias vías del progreso vivirán cual anhelamos los hombres, sin fronteras, como hermanos, sin tener baldón mugriento de reyes y sin tener más leyes que el amor y la equidad. Esto es lo que tenían que decir "Los anarquistas".

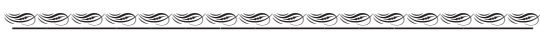

\section{¡Estridentes!}

Obreros de mi siglo, gladiadores incansables del trabajo, vosotros los que tenéis un corazón que late, que siente y que palpita al unísono de lo que es justo y grande y noble; vosotros los que lucháis infatigables para dar a los pueblos de la tierra y a las razas humanas todas nuevos y mejores derroteros y más amplios y espléndidos mirajes; vosotros los que sentís en vuestras frentes la llama abrasadora de la luz prístina y esplendente del mañana; vosotros los que cual yo amáis a la humanidad y nos os limitáis al círculo estrecho y vil de la familia; vosotros los que forjáis en vuestras mentes con miles de arabescos deslumbrantes, gigantescas y brillantes proyecciones del fúlgido esplendor de la prístina aurora ya cercana, aurora de nuestra redención de la ignominiosa esclavitud tirana; vosotros los que alzáis en el concierto humano vuestra voz de protesta atronadora; vosotros, en fin, los que ponéis vuestros brazos, vuestra energía, vuestra inteligencia y vuestra vida toda al servicio de la causa que creéis justa; anarquistas en fin del mundo entero, iyo os saludo!

Sí, yo os saludo y desde lo más recóndito de mi corazón, que os quiere y que os ama, os envío los ardientes votos de mi eterna simpatía.

Yo os saludo indomables y altaneros portavoces de la rebelión humana, yo os saludo.

No os importe que hoy las inconscientes muchedumbres os desprecien o que encogiéndose de hombros con irónica indiferencia os vuelvan la espalda, no os importe; esa misma multitud mañana os llamará hermanos, cuando haya comprendido vuestras ideas, no lo dudéis anarquistas, no lo dudéis, porque vosotros llevaréis el amor y la 
esperanza en vuestros labios, en vuestros corazones y icómo no engendrar el amor y el cariño al calor de vuestras nobles y justas aspiraciones?

No cejéis, no cejéis en vuestra obra, en vuestra tarea demoledora de absurdos, de infamias y de preocupaciones, esa multitud que hoy os mira indiferente u os desprecia; ha largos siglos que vive huérfana del amor y de [...] el látigo y la cadena del esclavo, y es por eso que se ríe y que encuentra extraño que le habléis de libertad y de cariño. Mas no importa, ya llegará un día que os comprenda y que os ame, y el día de la lucha, no lo dudéis, anarquistas, estará a vuestro lado.

Sed nobles cuanto podáis con ellos, explicadles con amor vuestras ideas, tratadles como a los niños, con cariño, que al fin os entenderán.

¡Ah! yo sé que hoy vagáis como espectros maldecidos, sin pan, sin amor y sin caricias, sin hogar y sin ternezas, de ésas que tanto el corazón ansía, arrojados, perseguidos como fieras; mas que eso no llegue a abatiros, vuestra obra es la obra de los grandes, de los buenos, de los incansables, y en ella, ya lo sabéis, ningún laurel pagará vuestros esfuerzos, ninguna mano amiga vendrá a levantaros si caéis, ni tampoco a cerrar vuestros ojos vidriados el día en que la muerte venga traidora a sorprenderos en la mitad de la jornada...

Mas ¿qué importa hermanos míos? ¿No vale más un solo latido de vuestros bravos y serenos corazones, una sola sonrisa de afecto, de las que como yo con todo corazón os aman, que toda la mentida grandeza y el vano aplauso de la inconsciente multitud embravecida por códigos infames, por absurdas leyes, por torpes fanatismos, por estúpidas preocupaciones? ¡De esa misma multitud que falta de energía y escasa de valor y de osadía, gime desconsolada, derramando ardiente lloro sobre las cadenas que la oprimen o al pie de la tumba de los suyos, muertos de hambres y de frío, en medio de las deslumbrantes esplendideces de las urnas!

¿No creéis que vale más uno solo de esos diamantinos ensueños que lleváis en vuestra mente que todo el oropel del mundo entero?

No cejéis en vuestra obra joh anarquistas! ¡Yo bien sé que vosotros seréis los náufragos perdidos en los procelosos mares de la vida, que de las tormentas por el rayo heridos: en desierto peñón el mar los bate, donde los negros buitres los devoran cuando han muerto!

Mas a pesar de todo, mientras quede en nuestras venas una sola gota de esta sangre ardiente y generosa de obreros conscientes y rebeldes que llevan en sus pálidas y pensadoras frentes proyecciones de la luz radiante del sol del porvenir; ;al aire nuestro rojo estandarte de pelea!, e irguiendo altivas nuestras frentes, pálidas sí, pero altaneras: iguerra a la mentira y a la infamia! iguerra a la infamante explotación inicua y a la opresión envileciente! iguerra!

Alcemos, sí, con valor nuestro estandarte, bajo cuyos pliegues gigantescos caben todos los que trabajan, los que aman, la raza toda humana de la tierra y ... imuerte a la opresión! sea nuestro grito de pelea. 
¡No más gemir ya, hermanos míos! Basta de calma.

¡A las armas, compañeros! ¡A combatir o a triunfar o a morir! ¡Volemos!

¡Corramos, sí, corramos! ¡Mirad que el minotauro burgúes se prepara a abatir nuestra entereza, mirad que quiere devorarnos!

¡Anarquistas! ¡Anarquistas! ¡Oíd mi voz que el entusiasmo inflama, sacudamos hermanos el marasmo que tiene entumecidos nuestros miembros, despertad de la apatía, obreros, mirad que el rasero de la iniquidad amenaza segar nuestras cabezas!

¡Despertad! ¡Despertad!

¡Tended la vista por doquier! España, Francia, Italia, Rusia, Turquía, Cuba, América; doquier sangre, doquier luto, muerte y exterminio. ¿Quiénes son los que mueren? ¿Quiénes, quiénes son las víctimas? ¡Los obreros siempre! ¡Siempre el inconsciente pueblo!

¡Barcelona allá! ¡Horror de horrores, sangre! ¡Crimen tras crimen!

¡Vivir es luchar, hermanos míos! En estos instantes supremos en que todo se desploma, en que todo naufraga y cae, en que todo va a perecer, en estos momentos de espantosa prueba en que lo viejo, lo malo, lo podrido saca fuerzas de los mismos estertores de su agonía, y que en un formidable esfuerzo pretende aniquilarnos; en estos momentos en que las religiones bajan a la tumba del olvido, cubiertas con el fúnebre sudario del polvo de los años [...] en que las viejas instituciones sienten crujir las [astillas] de su apolillado y carcomido maderamen: en estos supremos instantes en que todo cruje y se desploma, como esos inmensos témpanos de hielo cuando el sol abrasador los hiere con sus ardientes rayos, no tan fuertes como la irrefutable lógica de nuestras igualadoras ideas, serenidad y valor hermanos míos, firmeza en el pulso compañeros y guerra por doquiera a los potentes y hasta a la misma guerra iguerra!

\section{¡Anarquistas del mundo entero!} Oíd: los potentes del mundo todo, desde el Japón, ebrio de orgullo por sangrientas y recientes victorias, hasta la carnicera burguesía de la Europa entera y hasta la misma de la semi-salvaje Turquía, pretenden exterminarnos, y España da la prueba; desde el autócrata zar de la nebulosa Rusia, recorriendo la larga escala hasta los embaucadores socialistas, todos, todos sin dejar uno, son y están contra nosotros.

Pues bien, ya que todos ellos amontonan y apiñan fantásticos nublados sobre nuestras cabezas altaneras, y pretenden aplastarnos con la fuerza de su fuerza ¿creéis que debemos limitarnos a ser, en este mar bravío y proceloso, el abrupto peñón que firme en su asiento inconmovible, desafía la furia embravecida de las olas y las huracanadas ráfagas de la azotante tempestad asoladora?

¡No, voto a Luzbel! ¡Muerte a la muerte!

¡Obreros todos! Nuestras ideas son de paz, son de cariño, son de fraternidad y de armonía, mas ya que así se nos trata, y así se nos acosa, oídlo, bien, que alto lo decimos: Ya que el mundo entero nos declara audaz, sangrienta guerra, nosotros la aceptamos 
y despreciamos al mundo entero, ¡sí, lo despreciamos, no le tememos!

¡Puede, pues, arrojarnos el guante de pelea!

Que conste, pues: Los tiranos quieren cebarse en nuestras carnes con furor, preñados de orgullo, de odio, de cinismo, de maldad y de ambición, pues bien: nosotros abatiremos su maldad, su orgullo, su cinismo, su valor (?) y su ambición.

Anarquistas, hermanas mías: ¡Tiembla mi labio y febril por el papel vuela mi pluma!; yo quisiera hablaros de la idea de amor, de propaganda y de cariño, mas no puedo, no, no puedo como tampoco puedo llorar y lo quisiera; mas ¿qué mucho, que esto así suceda?

He tenido días sin pan y de amargura infinita, noches de insomnial tristeza, en que manando sangre el corazón herido, las sienes ardientes me latían y yo me contenía y oprimíalas y me oprimía el pecho, y entonces revolcándome con infernal e impotente rabia, nada de rencor y de venganza ansiosa, soñaba como hoy sueño, con montañas de escombros humeantes y arroyos de sangre de opresores. Y entonces golpeaba mis sienes, clavaba frebricente las uñas en mi seno y desgarraba mis carnes y respiraba rencor, odio y venganza, y me espantaba de mí misma; mas hoy, ¡oh, hermanas mías, después de lo hecho en Barcelona, ya nada, nada me espanta, yo os lo juro!

¿Cuándo se cumplirán nuestros sueños de venganza?

Hermanos anarquistas, vosotros los que ya hacéis lúgubres prisiones en los horrendos y negros cadalsos, los que inciertos vagáis años tras años, atravesando mares y montañas desiertos, como si fuerais espectros infernales; pero siempre serenos, siempre altivos, yo os saludo y entre los fervientes votos de mi fraternal simpatía, os envío mis besos como hermana y como mujer, las vibraciones de mi sereno corazón altivo.

¿Cuándo será el día de estrecharos las manos durante la pelea?

¡Acordaos de Barcelona y de Montjuich, hermanos míos!

Pepita Gherra

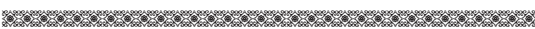

\section{A LOS OBREROS}

¡Sísifos del trabajo, salud!

Vosotros, los que durante el año transcurrido ni un momento os habéis detenido en la ruda y diaria labor vuestra, parad un momento la faena y escuchad la voz de la razón que os habla.

Paraos para recoger antes de proseguir vuestra cruda fatiga las lecciones que el pasado corto pero fecundo de los trescientos sesenta y cinco días transcurridos desde el año pasado nos ofrecen.

Sí, paraos, reflexionad en vuestro presente y sacad consecuencias para el porvenir.

¿Cuál fue vuestro pasado?

Trabajos, escaseces, privaciones, miserias, duelo y lágrimas.

El de vuestros padres, el de vuestros abuelos había sido igual.

¿Cuál es vuestro presente?

¡Ah! el año de padecimientos, el año de miserias, de vergonzantes miserias, os lo dicen. 
Sí, ese año que pasa, dejándoos como única caricia, como recuerdo único, las huellas de las noches de insomnio, de los días sin pan, sin trabajo y cariño.

La desgarradora letanía del quejido de vuestros niños enfermos, del ¡ay! desconsolador de vuestras esposas débiles y abatidas por los incesantes padecimientos y las palpitantes huellas grabadas en vuestros pulmones, en vuestras pálidas y abatidas frentes por los excesos de un trabajo incesante, embrutecedor y mal remunerado.

He ahí vuestro pasado y vuestro presente igual al de otros años, en que al terminar la postrera jornada de trabajo, teníais, tanto como cuando empezasteis la primera, el primer día, esto es: ¡Nada!

Y siempre así, igual fueron vuestros padres, igual vuestros abuelos e igual les pasará a vuestros hijos si no tratáis de poner remedio con mano firme a vuestros males.

Vuestras arcas no precisan pasar por otro balance, no tenemos más Debe ni más Haber que trabajar y más trabajar para el porvenir.

¡Cuán negro es todo esto, cuán negro! tanto más negro y horripilante, cuanto más tenemos la seguridad espantosa de su verdad innegable.

Entre tanto, ellos, los nobles, los potentes, los encumbrados, los amos y dioses de todo y de todas, tal día como hoy cuentan con intensa y profunda satisfacción el oro acumulado en los doce meses transcurridos, ese oro que tantas fatigas, tantos dolores os costó ganar a vosotros. Ese oro empapado en vuestra sangre y en las lágrimas de vuestros pobres niños, de vuestras infelices compañeras.
¡Y siempre así, lo mismo hoy que mañana, hasta que esto "cambie", que no cambiará seguramente mientras sigáis siendo como hasta hoy torpes, tímidos e indiferentes!

No cambiará, no, si los obreros siguen haciendo huelgas como la de los mecánicos de los talleres de Sola, como la de los imbéciles y presumidos telefonistas, como la de los panaderos, como la de... como todas, en fin, las que hasta hoy se han hecho.

No cambiará si siguen siendo los obreros creyentes de un buen futuro, patriotas embrutecidos por absurdas creencias, fanatizados por curas y por gobiernos, por religiones y leyes inútiles, embrutecedoras y anti-naturales.

No cambiará mientras las mujeres sigan siendo indiferentes a cuanto debiera interesarles y mientras sigan adorando trozos de maderas, engordando curas, proveyendo iglesias, etcétera.

No cambiará seguramente mientras haya lobos y mansos corderos, incapaces de pensar y obrar por sí mismos; no cambiará mientras los obreros no comprendan que es preciso, que es imprescindible que cambie.

Para que el cambio se verifique trabajamos nosotras y con nosotras toda persona de corazón noble.

¿Cuándo se verificará el cambio? Cuando los pueblos comprendan lo que es la Anarquía.

Entre tanto, nosotras, no pudiendo manifestar de otro modo la indignación y el dolor que nos embarga el día de hoy, en que todos cuentan sus alegrías, sus triunfos y el fruto del trabajo del pueblo obrero, no pudiendo manifestar de otro modo nuestra disconformidad, con toda esa turba de misera- 
bles sin corazón, protestamos en este número de LA VOZ DE LA Mujer porque ella no puede estar y no está conforme con el régimen social que nos abruma. Y antes de proseguir nuestra marcha, antes de empezar la primera jornada de trabajo del año que comienza y que, como todos, sólo miseria nos promete, no podemos menos que decir a los potentes que no se vanaglorien porque muy pronto los débiles, sacando fuerza de su aparente debilidad, alzando $[\ldots]$ su voluntad con las [...]

\section{[...] LA RedACCIÓN}

c.

\section{A los lectores}

Un año ha transcurrido desde que salió a luz el primer número de LA Voz de LA Mujer.

Un año de luchas, de sacrificios, de crueles alternativas, de esperanzas y de caídas, solamente atenuadas en algo, por satisfacción de la lucha.

Dos Redacciones han estado a cargo de esta hoja, poniendo las dos su corta inteligencia y sus energías todas al servicio de la causa que defienden: La Anarquía.

En este año la vida de esta hoja ha sido precaria y raquítica, tanto así, que con pesar confesamos que si los compañeros no tratan (si les agrada nuestra propaganda) (1) de ayudarnos un

(1) A este respecto decimos: que dado el estado de ignorancia en que están sumidas las mujeres, nosotras entendemos que nuestra misión periodística es labrar la inteligencia, otro periódico o este mismo más tarde sembrará y cultivará el grano. Por esto nuestra propaganda es como es, cada periódico tiene su misión si quiere. poco más eficazmente, nuestros esfuerzos serán inútiles y tendremos que cesar de publicar La Voz de la Mujer (2) y con ella la del ÚNICO periódico de América y tal vez del mundo entero que hace propaganda de nuestros ideales por mujeres y especialmente para ellas.

Lo repetimos compañeros y compañeras, entusiasmo y voluntad no nos faltan, pero nuestras fuerzas son pocas; por eso, si no podemos más, nos retiraremos hasta poder volver de nuevo a la brecha, y así siempre hasta que la hora del combate suene en el reloj de la conciencia humana, para correr a vencer o a morir por la Anarquía, porque por ella dará su inteligencia, su brazo y su postrer suspiro

La Redacción de la Voz de la Mujer

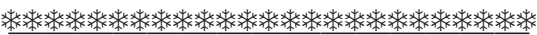

\section{SILUETA $5^{a}$}

Enjuto y seco de carnes, lo es más de cara, en la cual una seriedad fría, parecida a la del búho, se ha estereotipado.

Cejijunto y grave pero de una gravedad venenosa, ante él la más pura sonrisa se hiela, la alegría más bulliciosa, más pura e infantil, se trueca en terror, sólo comparable al que se siente cuando os pasan estando descuidados el filo de un puñal por la garganta.

De sus ojos semiocultos en las órbitas y cubiertos por los inseparables lentes sale una mirada que hace daño, una mirada que paraliza la circulación de

(2) $O$ entregarla a otras compañeras con más aptitud y fuerzas. $N$. de la $R$. 
vuestra sangre y que hiela el corazón, no precisamente porque se le tenga miedo, no, sino porque... es fatídica, dañina; es, en fin, una mirada de avaro, que tal es él a su manera, porque lo es de infamias a juzgar por el afán con que día por día las va amontonando una tras otra.

En su presencia os sentiréis inquietos a la fuerza, y sin saber por qué; tal vez por intuición, pues para ese hombre la menor acción es un acto punible, el menor gesto una delación y la más insignificante equivocación señal de culpabilidad.

Sus labios secos y contraídos por causa de su hipócrita y eterna gravedad causan inquietud.

Sus movimientos son acompasados, lentos, graves y su voz hueca, seca y breve.

Cada ademán suyo es una siniestra y fatal maldición que se cumplirá de fijo y que costará a la persona contra quien sea dirigida días y más días, meses y aun años de sufrimientos atroces, de crueles padecimientos.

Cada palabra suya es una terrible acusación de la que a pesar de ser inocente, difícilmente lograréis salir incólumes, acusación en que muchas veces va envuelta una sentencia tal que pone en peligro vuestra vida, vuestro honor, el pan, el reposo, el amor de vuestra esposa, acusación que él pronuncia con una indiferencia tan glacial, con una despreocupación tal, que hiela, espanta, aterra.

[No es] un hombre, es una hiena, pero una hiena [...] e inmensamente sanguinaria.

Creeríais que hace el mal por placer y no es tal, lo hace sólo por instinto de imbécil, de idiota.
Derramar sangre porque sí y sin saber por qué, pues de su cerebro embotado no sale ni un solo pensamiento, ni una sola idea, he aquí su instinto.

Cuando es joven, cuando aún no es más un aprendiz de pantera hay en él algo nauseabundo, algo que su juventud no es capaz de hacer desaparecer, se diría que huele mal, que trasciende a verdugo, a cadalso, algo infinitamente lúgubre.

Figuraos un atolondrado calavera, que a las diez o más de la mañana se levanta del lecho de su querida, y después del desayuno, coge su varita y haciéndola girar entres sus dedos se dirige alegre y satisfecho a su despacho.

Llega y con la sonrisa en los labios saluda, entra, se sienta, pregunta qué novedades hay y luego con dos o tres plumazos, falla y más falla, repartiendo sin ton ni son años y años de dolor y de tinieblas.

Si su cabeza no está aún bien despejada de los vapores del alcohol que bebió en la orgía de la noche anterior, lo mismo os aplicará veinte años de cárcel que os dará la libertad, porque es así, un imbécil atolondrado, un proveedor del verdugo que aún no tomó gusto al oficio.

Después de lo cual tomará el sombrero e irá a pasar la tarde a tal o cual casa, sin acordarse para nada del padre que acaba de matar civilmente, ni de los niños a quienes de un plumazo acaba de sumir en la mayor y más espantosa miseria para siempre.

Pero después de todo es un cachorro de lobo carnicero, y, como tal, no aterra tanto, no es tan repulsivo.

Veámosle cuando ya la tierra desarrolló sus instintos, cuando ya lame 
con cierta indiferencia la sangre de sus víctimas que chorrea de sus fauces entreabiertas.

Suponed que por cualquier causa os llevan a presencia de esa hiena.

En cuanto que llegáis, os clava su mirada felina y penetrante y da comienzo a su tarea de urdir mentiras, da comienzo a su táctica de viejo lobo carnicero, tratando de sorprender con su perfidia y su práctica de viejo la menor señal de inquietud de que deis muestra.

Os acosará de preguntas, sin daros un instante de reposo, hasta tanto no logre convenceros de que sois culpable.

Sorprenderá vuestro sueño, os espiará, os agobiará poniendo en juego toda su malicia y su perfidia, os buscará, en fin, la vuelta como se dice de un canalla, para haceros caer en la trampa, y cuando lo consiga, una imperceptible sonrisa de satisfacción se dibujará apenas en sus labios y un siniestro relámpago de placer brillará en sus felinos ojos.

¡Oh creedme! es repugnante y hasta da náuseas al corazón el verle empeñado en su siniestra tarea.

El menor gesto, la menor vacilación y sois perdidos para siempre, hundidos en la nada de un calabozo que os agobiará, que os estrecha, os oprime, que os mata, en fin, lejos, muy lejos de los que os aman, de los que os podrían prestar algún consuelo, algún alivio.

La persona de ese chacal en forma humana trasciende a tumba, huele a muerte, de su mirada oculta tras los vidrios de sus anteojos parecen salir fuegos fatuos de esos que de noche salen de las tumbas, su aliento enve- nena el corazón, pudre la vida, su mano mancha, sí, mancha.

Su solo paso por vuestro hogar dejará un reguero de lágrimas y de duelos, todo lo pudre, todo lo ennegrece.

¡Ah, yo quisiera que lo vierais cuando después de haber condenado a muerte a un semejante basándose en no sé qué cosas que dicen no sé qué librotes, que otros de corazón tan duro como el suyo y de cerebro y razón tan embotados como la suya también han escrito, va a su hogar, al seno de su familia (las hienas y los tigres también tienen su prole), y con la misma tranquilidad, con la misma indiferencia que el obrero que acaba de llegar de su agobiador trabajo diario, se pone a comer, pues a él nunca le faltan alimentos como a nosotros.

Yo quisiera que le vierais, que le oyerais leyendo una sentencia, con su voz monótona y seca, cuando va amontonando necedad, mentira tras mentira para concluir pidiéndoos que le deis vuestra conformidad para que todo aquel tejido de infamias se lleve a cabo.

Observadle y veréis que el día que la sentencia infame se cumpla irá rodeado de sus ayudantes (los vigilantes, soldados y demás), a entregar la persona del infeliz reo en manos del verdugo, y más tarde irá a lamer la sangre que destilan las tablas del cadalso.

Y no obstante, este negro personaje no quiere codearse con el verdugo y a fe hace bien, porque lo mancharía y el deshonrado sería este último.

Este engendro de negruras no quiere a nadie, no tiene afecto alguno, no quiere ni a sus amigos, ni a sus hijos, ni esposa, ni a sus padres, porque para 
él todos son criminales posibles, pasados o futuros.

Jamás se ríe ni se alegra, de su corazón seco y arrugado jamás obtendréis una expansión. Verdadero espejo de sí mismo, todo lo ve color sangre, todo es delincuencia, todo son infamias para él. ¡Verdadero cuervo, se sustenta con los despojos de la diaria batalla de la vida!

\section{(Concluirá)}

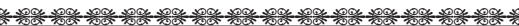

\section{MESA REVUELTA}

En carta que hemos recibido se nos comunica esto :

... Habiendo anunciado que los lavaderos municipales serían entregados a una empresa particular, el Administrador del que lleva el número 4, situado Balcarce entre San Juan y Comercio, temiendo quedarse sin su empleo, o por lo menos verse privado de guardar para sí la tercera parte de lo que las lavanderas pagan por el derecho de lavar, imaginó una treta tan ruin y tan infame, que basta ella para poner de relieve lo miserable de los sentimientos del tal Administrador.

Les hizo firmar una solicitud diciéndoles que en ella se pedía que los lavaderos no pasaran a manos particulares, y como la mayoría de las lavanderas no saben leer, él les leía lo que le parecía, ocultando lo demás. Las 8 o 10 que firmaron, como las demás por quienes él firmó sin consentimiento de ellas, ignoraban que la solicitud pedía que en vez de trasladar los lavaderos, se aumentara el impuesto que se cobra a las lavanderas al doble de lo de hoy, cosa con la que de ningún modo están conformes ellas, y de la que enseguida protestaron.

El tal Administrador, al saber que las lavanderas protestaban de su proceder, las amenazó con mandarlas a la cárcel, con prohibirles lavar y por fin con correrlas a balazos si no pagaban lo que él quería. Entre tanto las lavanderas se presentaron al Concejo Deliberante, en el cual es muy posible no las atiendan, porque, como ya dijo él, el Administrador disfruta de gran confianza en las esferas del Concejo.

Ahora bien, nosotras que tenemos un poco más de práctica que ellas en estas cosas aconsejamos a las lavanderas romperle algo importante al tal estafador (pues fue una estafa con engaño) la que les ha hecho.

Dicen las que nos escriben que son cerca de 200 las que protestan; pues bien, a ese tipo que tan descaradamente abusó de la buena fe e ignorancia de ellas, al tal (Manco) que firmó por varias sin su consentimiento de ellas, la mejor justicia, la mejor queja, ya lo hemos dicho, es partirle el cráneo.

En cuanto a lo de la prisión y los balazos, diremos: Don Manuel, es usted un mico que ni manda preso ni pega balazos ni hace ná, porque no, porque no sirve $\mathrm{Ud}$., porque $\mathrm{Ud}$. no es chicha ni limoná.

Pero después de todo conocemos su domicilio (Caseros entre Perú y Chacabuco) y como llegue a nuestros oídos que Ud. hace el más mínimo acto de venganza contra las lavanderas vamos a su pocilga y ni ratones quedan ¿oye?, ¡so marica! 
Compañeras lavanderas: lo que habéis de hacer es quitar a ese soplón lo que de hombre pueda tener y las barbas y los ojos y todo lo que os parezca quitable.

Y si se os ofrece algo, contad con nosotras y con las columnas de LA Voz De Mujer.

Allá por el año 1880 , si mal no recordamos, el civilizador gobierno argentino envió parte de su ejército en misión civilizadora también, a la conquista del desierto.

Como la civilización iba en las puntas aceradas de las lanzas y bayonetas del tal ejército, claro está que la cosa produjo óptimos resultados y la civilizadora cosecha fue espléndida.

Se cazaron, queremos decir se civilizaron a medias unos 800 indios, amén de los que se civilizaron del todo, que de esos no conocemos el número, porque los civilizadores no dijeron a cuánto alcanzaba el número de muertos.

Los indios a quienes sólo a medias se consiguió civilizar fueron traídos a ésta y distribuidos (de la manera más civilizadora posible) los varones en el ejército permanente y las hembras entre las distinguidas y decentísimas matronas que todos los días se confiesan, que todos los días van a misa, que todos los días desprecian a la plebe (vulgo proletariado) (que según ellas y su Dios es hermano suyo), y que todos los días también pegaban de la manera más cariñosamente civilizadora posible a aquellas infelices, algunas de las cuales están aún (como se verá más abajo) continuando su aprendizaje de civilización, apenas interrumpido por las faenas de mucama, cocinera, etc., pero no se crea por esto que trabajan gratis iqué esperanza! reciben una espléndida remuneración (paga) en azotes, palos, cachetes y ayunos forzados ¡oh civilización!

El distinguido caballero y pundonoroso oficial del cuerpo de Bomberos de esta capital, Sr. Fossa, es uno de los muchos (hay que confesarlo, son muchos) que continúan a través de los 16 años transcurridos la ingrata tarea de civilizar a estos testarudos de indios, que son brutos a más no poder. ¡Figúrense nuestras queridas lectoras que el caballero Fossa está civilizando a una india, mujer de edad ya, la cual (cosa increíble y que hasta parece mentira) a pesar de los 16 que lleva de estudiar en la... tina de lavar la mugre del caballero Fossa no ha aprendido ni la $O$ por larga!!

¿Verdad que después de 16 años de lavar patios y ropa, de cebar mate y chanchos, de cocinar, de pasar hambre, y de llevar cachetadas (parece mentira) no pueda un indio aprender la $\mathrm{O}$ ?

Pero aún hay más, la india de Fossa (la sirvienta, no la esposa) tiene una hija a la cual los niños ipobrecitos! enseñan a multiplicar... en pago de lo cual su vida de ella en la casa del pundonoroso Fossa es algo peor.

Los palos, ni se diga: hambre para mantener un regimiento, y para mejor tanto es el cariño que le tienen, que le prohíben llamar madre a la autora de sus días. Per cosa? Non si sá.

Nota - El señor Fossa no cobra nada a esas dos indias por tenerlas en su casa, ni tampoco por civilizarlas.

Otra - Nos han contado las hadas del bosque que Villalba, el infeliz sol- 
dado muerto a palos por los distinguidos oficiales del 11 de Infantería, repitió a cada uno de los 2.500 (dos mil quinientos) que le pegaron lo siguiente : "Hermoso sol de libertad el que hoy luce". ¿Quieran los electores hacerme el favor de creer que los indios que están hoy todavía en el ejército permanente y las indias en poder de las familias decentes repiten lo mismo?

¡Si serán desagradecidos esos pícaros! .......

Si alguno duda de que los partidos políticos quieren el bien del pueblo, que lea esto y hablaremos.

Cuando el famoso Partido Radical hizo la no menos famosa revolución del año '93, las proclamas y promesas eran lo de menos.

"Todo para y por el pueblo", y así se hacía.

Entre los que formaron en las filas de los embaucadores radicales, había tres jóvenes que, acosados por la necesidad, quitaron a un vasco, propietario y acaudalado vecino de Dolores, lugar donde sucedió lo que narramos, una suma de dinero cuyo monto no recordamos.

El tal vasco dio parte a la autoridad, como es natural, ya que ésta no tiene otra misión que defender a los ricos, las autoridades del pueblo eran todas compuestas de radicales, y la que recibió la denuncia del vasco la representaba el ladrón honorabilísimo por sus pesos D. Domingo Negri, comisario del pueblo de Dolores.

Ahora bien, los jóvenes en cuestión habían peleado y expuesto sus vidas por conquistar su libertad, y como eran tontos, la creyeron asegu- rada cambiando las autoridades, en el cual cambio tocó en el reparto el puesto de comisario al antedicho Negri.

Con lo antes dicho queremos decir que esos jóvenes y otros como ellos, y como ellos pobres, habían encumbrado al tal Negri, y que a éste, igual que al anterior, un comino le importaba que los que lo habían encumbrado tuvieran o no hambre.

El caso es que el tal Negri, apenas recibida la denuncia, procedió a la prisión y desarme de los jóvenes en cuestión, y después de engrillarlos y maniatarlos, los abofeteó delante de las tropas-ciudadanas (cosa que no haría si hubieran estado libres y solos) y después de ponerles un cartel en el pecho y otro en la espalda, los puso a la expectación pública y con centinelas de vista.

El abofeteamiento tuvo lugar en las calles San Martín y del Plata, frente a la Municipalidad del ya citado pueblo.

El suceso en sí es nimio, mas en sí trae lo grande, y su moraleja es ésta:

"No se debe encumbrar a nadie."

Traslado a los que de buena fe creen en la bondad de los diputados socialeros.

Trae a más las consideraciones siguientes:

Nosotros los proletarios de ambos sexos al luchar por nuestra libertad debemos hacerlo por el sustento, porque los que como nosotros carecen de pan no pueden ser libres, pues para tenerlo, se verán obligados a emplearse, esto quiere decir que nos ponemos mediante un sueldo mensual o semanal a la completa voluntad del que nos paga, el cual por ende nos gobierna a su capricho o antojo 
¿somos libres en tal caso? No, puesto que hemos vendido nuestra voluntad.

Se me dirá que se puede cambiar de patrón, pero yo contestaré que gobiérneme un Azul o un Negro, un Chino o un Español, para mí es igual, soy mandado.

Se me dirá que los partidos políticos, lo que prometen es libertad política y no económica... Mas yo respondo, la libertad es una, una sola y mientras haya una sola facultad que no sea libre, no hay libertad.

Además, ¿qué se entiende por libertad política? la de votar, reunirse, etc., para ello es preciso ser iguales ante la ley.

Pero la ley es cosa hecha y por lo tanto factible de ser errónea, no cabe duda de que el hombre vende su libertad, y de que el oro compra la ley tampoco cabe duda.

Que los que hacen y aplican la ley son ricos, [no cabe] duda, que nos comprarán nuestra libertad y que no podemos comprarles su ley ¿quién lo ignora?

De qué sirve la libertad política si tendremos que venderla (vendiendo el voto, venderla para conservar el empleo, etc.) Yo entiendo por libertad el ser dueño de sus acciones, sin más restrintivo que su saber.

Instruyámonos pues, y procuremos ser libres, pero libres en todo el sentido de la palabra, no libres de votar y no de comer.

"Productor" - (Coruña) Recibimos carta y contestamos, salud.

- H. Tisby. Recibimos carta. No podemos traducir. Contestaremos por carta.

- Línea de la Concepción, I. M.
G. - Tu hermano dice que no escribes. ¿Recibiste carta?

- Línea de la Concepción: Grupo los Decididos - Recibimos carta y contestamos.

- Hemos recibido "El Perseguido", "La Revolución Social", "El Oprimido", "L'Avvenire", "La Anarquía", "La Nueva Humanidad", "Le Libertaire", "La Nouvelle Humanité", "Les Temps Nouveaux", "La Questione Sociale" (Paterson), "El Esclavo", "El Despertar", "El Productor" y su hoja manifiesto "O Trabalhador", y "A Obra"; también hemos recibido el Almanaque de "La Questione Sociale" editado por la Librería Sociológica, cuesta 50 centavos. Corrientes 2039. A todos gracias, salud y propaganda.

- También hemos recibido dos hojas sueltas, una firmada por Mengano de Tal y otra por Un compañero.

Esperamos ver las obras que prometen escribir, para hacer al respecto de ellas algunas consideraciones.

\section{Importante:}

No habiendo podido reunir lo necesario para publicar el manifiesto "Ante el Cadalso" lo publicamos en La Voz de la Mujer y destinamos lo recolectado al periódico.

Los que no están conformes reclamen y les devolveremos el dinero.

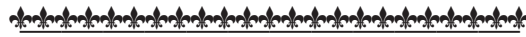

Suscripción Voluntaria

PARA EL NÚM. 9 DE

"LA VOZ DE LA MUJER"

CAPITAL

Un anarquista 0.10, Libertad 0.10, ¡Ay qué dichoso cuando una bella moza se fijó 
en un joven que vestía con traje negro! 0.30. Total 0.50

Lista núm. 52 - Ácrata 0.20, Salvador Monte 0.10, I. Muñiz 0.10. Total 0.40

Lista núm 75 - M. M. Yo F. E. 1.00 (para los presos de Barcelona), Compañera de El Iris 0.50, Expropiación 0.50, Otra compañera 0.50 - Total para LA Voz DE LA Mujer I.5O.

Lista núm. 17 - (Del número 8 de La Voz). Sobrante de una convidada 0,20, Sobrante de un café 0.25. Total 0.45.

Por conducto de La Questione Sociale, Leandro Krata 1.00, Feliz Q. Rueda 0.50, M. E. F. 0.55. Total 2.05

Lista núm. 11 - (Corresponde al número 8 de la La Voz) por conducto del Grupo Juventud Unida - Un marmolero 0.50, Un decidido 0.20, Natividad Juanto 0.20, Su compañero 0.20, Su hijo 0.10, Un imbécil 0.25, Una jugada 0.25, Francisco Berri 0.20, Su compañera 0.10, Sobrante de un viaje a San Isidro 0.20- Total 2.20.

Lista núm. 26 - Por E. B. ¿Qué quieres que te ponga? 0.10, Un explotado 0.10, Para lo que quieras 0.20 , Uno que no tiene más 0.10 , Luisa Priani 0.10, Un regalo a LA Voz de LA Mujer 0.50, Un cigarrero 0.10. Total 1.20.

Listas núms. 26 y 46 - Varios compañeros de Guardia Nacional 0.30, Un socialista revolucionario 0.30, Satanás 0.40 . Total 1.00.

Lista Núm. 120 - Amor libre 0.20, Una costurera 0.10 , Una de la idea 0.10 , Un convencido 0.10 , Una planchadora, 0.10 , La anarquía es un ideal sublime 0.20, G. F. 0.20, Eduardo Castro 0.20, Uno que no quiere cuernos 0.20 , Al que no quiere caldo se le debe dar dos tazas 0.05. Total 1.45.

Grupo Zapateros descalzos:

Juana sin patria, 0.10, Nicolás Perita 0.20, José Rabioso 0.15, Juez 0.15, Dos centavos 0.20, Cualquier nombre 0.10, Un encargado zapatero 0.20, V. V. 0.20, Sobrante de un palco entre compañeros 1.50, El tuyo 0.05. Total 2.85.
Grupo de Estivadores:

Un andaluz 0.05, Otro 0.05, Un guerrero 0.20 , Nicolás Oriental 0.10, Mi tío Pallás 0.05, Me 0.07, Bomba Orsini, 0.10, Un belinun 0.10 , Un coruñés 0.10 , Un harto de sufrir 0.10, Francisco Cicari 0.50, "El errante” 0.08, Rosa Rubinal 0.10. Total 1.60.

Lista núm. 101 - I. A. 0.20, Un falsificador 0.25, Sinforiano López 0.20, Yo mismo 0.20 , Un fundidor asturiano 0.20 , Un mordido por un mono 0.20, Mono sabio 0.30, Mono loco 0.10, D. L. Satanás 0.10, Un colchonero 0.10, Un carrero 0.20, Un fa, fi, fe 0.20, Un alerta 0.15. Total 2.40.

Lista núm. 51 - Sobrante de caña 0.25 , B. L. 0.20, Sombrero 0.05. Total 0.50.

Lista núm. 15 - Catalina Grajales 0.50, Uno que no está conforme con los padrinos del duelo 0.20, Natividad Juanto 0.20, G. M. 0.50, Juan Spaudonari 0.40, Bernarda Mañetto 0.20, Manuela Peiró 0.50, Total 2.50 .

De la Boca: lista núm. 33 - Supa-no-sta 0.10, Campana 0.10. Total 0.20.

Lista núm 23 - C. B. 0.10, Dinamitero 0.20, Un cura 0.50, A. Canaveri 0.20, Un Riem 0.10- Total 1.10.

Recolectado por el grupo Juventud Unida:

[...] Adela 0.20, Rosa 0.20, [...] María 0.20 , Fermina 0.20 , Un paisano de Pallás 0.10, Otro Pallás 0.10, Águila 0.20, Francisca 0.50, Josefa 0.05, Teodora 0.10, Luisa 0.20, Ángela 0.20, Inés 0.10, Carmen 0.10, Camieta 0.20, Camelia 0.20, Rubia 0.20, Tertulia 0.20, Antonia 0.05. Total 4.70.

Grupo Los Cocheros:

Una cochera 0.50 , Un tungo reventado 0.25, Perice Julia 0.10, Delia Girardino 0.20, Felice Lera 0.14 Michele Luiano 0.10. Total 1.29.

Fuego y exterminio 0.25, Uno que empieza a pensar 0.50 , Un anarquista de corazón 0.25 , Un temerario asturiano 0.50 , Cerviago 0.20, Astigiario 0.10. Total 1.80.

Por conducto de la Questione Sociale:

Misdoris 0.10, Maceo murió si o no 0.50, O Miarcani (Ayacucho) 0.50. Total 1.10. 
Destinado al manifiesto: Un rengo ácrata 0.20 , Cualquier cosa 0.20 , Lo que venga 0.20 , Lo que quiera 0.10 , Un desgraciado 0.20 , Un pescado asado 0.50, Rasca Buches 0.20, El pulpo asesino 0.20, D. Tisifilo 0.20, Llame José 0.50, Del Grupo Juventud Unida 2.00. Total 4.50.

Villa 1.50, Un colchonero 0.15, Grupo de la Panadería Tizoni 2.00, Viva el pueblo libre 0.50, Un explotador 0.20, Libertad 0.50 , Un gallego panadero 0.10 , Fuego y exterminio 0.50, Sarmiento 0.50, Una cocherita 0.30, Grupo Los Ácratas 0.72, Un colchonero 0.60, Sarmiento 0.50, Urquiza 0.30, Cualquiera 0.40, Escaño 0.20, Por no cobrar un café 0.15, T. H. 0.50, Sobrante de copas $1.30+0.20$ - Total 11.12.

\section{INTERIOR}

De Villa Constitución: Lista núm. 50: Candelario 1.00, El que suscribe 2.00, Una de la Coruña 2.00. Total 5.00.

(Esta lista pertenece al número pasado.)

De Mar del Plata - Eugenio C. R. 1.00.

De Córdoba: Lista núm. 72 - 1.50.
De Córdoba: Lista núm. 62: Para El Perseguido 1.00. Quedan para LA Voz DE LA Mujer 1.00, Sabonarola 0.20- Total 8.70

EXTERIOR

De Francia - H. Zisliy 0.25 .

RESUMEN

Recolectado: De la Capital \$46.81 Interior $\$ 8.70$

Exterior $\$ 0.25$

Total \$55.76

Gasto: Por 1.500 ejemp.

de este núm. $\$ 35.00$

De Correo \$8.00

Por pago de seis meses

de casilla $\$ 6.00$

Déficit anterior $\$ 24.08$

Total

$\$ 73.08$

Déficit actual 